


\title{
Effecten van klimaatverandering, eiwittransitie en gezamenlijk grondgebruik op akkerbouw- en melkveebedrijven
}

W. van Dijk, P. Brinkman, J.W. Bijker, D. Verstand, M.W.J. Stienezen, R.L.G. Zom \& A. Dawson

Met medewerking/bijdragen van J.G. Conijn en J. Jager

WAGENINGEN

UNIVERSITY \& RESEARCH 



\section{Effecten van klimaatverandering, eiwittransitie en gezamenlijk grondgebruik op akkerbouw- en melkveebedrijven}

W. van Dijk ${ }^{1}$, P. Brinkman ${ }^{1}$, J.W. Bijker ${ }^{1}$, D. Verstand ${ }^{1}$, M.W.J. Stienezen ${ }^{1}$, R.L.G. Zom ${ }^{1}$, A. Dawson $^{1}$

Met medewerking/bijdragen van J.G. Conijn ${ }^{1}$ en J. Jager ${ }^{1}$

1 Wageningen University \& Research

Dit onderzoek is uitgevoerd door de Stichting Wageningen Research (WR), business units Wageningen Plant Research en Wageningen Livestock Research, in het kader van de publiek private samenwerking (PPS)

Bouwplannen onder klimaatverandering en eiwittransitie (AF-18154) en Optimalisering gezamenlijk grondgebruik akkerbouw en melkveehouderij (AF-18153).

WR is een onderdeel van Wageningen University \& Research, samenwerkingsverband tussen Wageningen University en de Stichting Wageningen Research.

Wageningen, December 2020 
Van Dijk, W., P. Brinkman, J.W. Bijker, D. Verstand, M.W.J. Stienezen, R.L.G. Zom \& A. Dawson, 2020. Effecten van klimaatverandering, eiwittransitie, en gezamenlijk grondgebruik op akkerbouw-en melkveebedrijven. Wageningen Research, Rapport WPR-1062; 139 blz.; 50 fig.; 48 tab.; 56 ref.

Dit rapport is gratis te downloaden op https://doi.org/10.18174/537655

Trefwoorden: Klimaatverandering, eiwittransitie, grondruil, bouwplan, akkerbouw, melkveehouderij

Dit onderzoek is mede mogelijk gemaakt door:

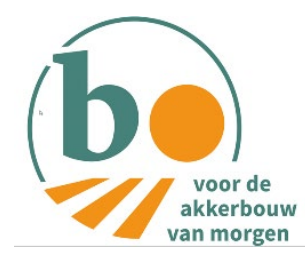

\section{ZuivelNL}

(C) 2020 Wageningen, Stichting Wageningen Research, Wageningen Plant Research,

Agrosysteemkunde, Postbus 16, 6700 AA Wageningen; T 03174807 00; www.wur.nl/plant-research

KvK: 09098104 te Arnhem

VAT NL no. 8113.83.696.B07

Stichting Wageningen Research. Alle rechten voorbehouden. Niets uit deze uitgave mag worden verveelvoudigd, opgeslagen in een geautomatiseerd gegevensbestand, of openbaar gemaakt, in enige vorm of op enige wijze, hetzij elektronisch, mechanisch, door fotokopieën, opnamen of enige andere manier zonder voorafgaande schriftelijke toestemming van Stichting Wageningen Research.

Stichting Wageningen Research is niet aansprakelijk voor eventuele schadelijke gevolgen die kunnen ontstaan bij gebruik van gegevens uit deze uitgave.

Rapport WPR-1062

Foto omslag: veldbonen (eigenaar Ruud Timmer) en perceel aardappel naast mais (eigenaar Wim van Dijk) 


\section{Inhoud}

Woord vooraf

$\begin{array}{ll}\text { Samenvatting } & 11\end{array}$

1

$\begin{array}{ll}\text { Inleiding } & 15\end{array}$

$\begin{array}{lll}1.1 & \text { Aanleiding } & 15\end{array}$

$\begin{array}{lll}1.2 & \text { Doel en afbakening } & 15\end{array}$

$\begin{array}{lll}1.3 \text { Aanpak } & 15\end{array}$

$\begin{array}{lll}1.4 & \text { Leeswijzer } & 16\end{array}$

$2 \quad$ Eiwittransitie $\quad 17$

$\begin{array}{lll}2.1 & \text { Inleiding } & 17\end{array}$

$\begin{array}{lll}2.2 & \text { Eiwitopbrengst gewassen } & 17\end{array}$

$3 \quad$ Klimaatverandering $\quad 19$

$\begin{array}{lll}3.1 & \text { Achtergrond en introductie } & 19\end{array}$

3.1.1 Effecten voor de landbouw $\quad 21$

3.2 Aanpak verkenning risico's teelten voor klimaatverandering 22

3.2.1 Aanpak 23

$\begin{array}{lll}3.3 & \text { Resultaten } & 25\end{array}$

3.3.1 Klimaatrisico's eiwitgewassen $\quad 25$

3.3.2 Klimaatrisico's referentie gewassen 32

$\begin{array}{lll}3.4 & \text { Conclusies } & 36\end{array}$

3.4.1 Klimaatrisico's eiwitgewassen 36

3.4.2 Eiwitgewassen versus standaard gewassen 36

$4 \quad$ Bodempathogenen $\quad 39$

$\begin{array}{lll}4.1 & \text { Vermeerdering en schadegevoeligheid } & 39\end{array}$

4.2 Effecten van klimaatverandering 43

4.3 Aanbeveling voor bouwplannen 45

$\begin{array}{lll}5 & \text { Bouwplannen per regio } & 47\end{array}$

$\begin{array}{lll}5.1 & \text { Noordoost-Nederland (NON) } & 48\end{array}$

$\begin{array}{lll}5.2 & \text { Zuidoost Nederland (ZON) } & 49\end{array}$

$\begin{array}{lll}5.3 & \text { Centraal-Nederland (CEN) } & 50\end{array}$

5.4 Zuidwest-Nederland (ZWN) 51

$6 \quad$ Uitgangspunten berekeningen en beoordeling bouwplannen 
6.1 Uitgangspunten berekeningen 55

6.1.1 Algemeen $\quad 55$

6.1.2 Akkerbouw 56

6.1.3 Melkveehouderij 57

$\begin{array}{ll}6.1 .4 \text { Systeemeffecten } & 61\end{array}$

$\begin{array}{lll}7.1 & \text { Noordoost-Nederland } & 63\end{array}$

$\begin{array}{lll}7.1 .1 \text { Economie } & 63\end{array}$

7.1.2 Nutriënten en organische stof 66

$\begin{array}{ll}7.1 .3 \text { Broeikasgasemissies } & 68\end{array}$

$\begin{array}{ll}7.1 .4 \text { Bodemgezondheid } & 69\end{array}$

$\begin{array}{lll}7.2 & \text { Zuidoost-Nederland (ZON) } & 74\end{array}$

7.2.1 Economie 74

7.2.2 Nutriënten en organische stof 78

$\begin{array}{ll}7.2 .3 \text { Broeikasgasemissies } & 80\end{array}$

$\begin{array}{ll}\text { 7.2.4 Bodemgezondheid } & 80\end{array}$

$\begin{array}{lll}7.3 & \text { Centraal-Nederland (CEN) } & 84\end{array}$

$\begin{array}{ll}\text { 7.3.1 Economie } & 84\end{array}$

7.3.2 Nutriënten en organische stof 87

7.3.3 Broeikasgasemissies 88

$\begin{array}{ll}\text { 7.3.4 Bodemgezondheid } & 88\end{array}$

$\begin{array}{lll}7.4 & \text { Zuidwest-Nederland (ZWN) } & 93\end{array}$

7.4.1 Economie 93

7.4.2 Nutriënten en organische stof 96

$\begin{array}{ll}7.4 .3 \text { Broeikasgasemissies } & 97\end{array}$

$\begin{array}{ll}7.4 .4 \text { Bodemgezondheid } & 97\end{array}$

7.5 Verkenning organische stof bij gezamenlijk grondgebruik 101

$\begin{array}{llr}8 & \text { Discussie } & 107\end{array}$

9 Synthese $r 11$

9.1 Gezamenlijk grondgebruik en teelt van eiwitgewassen $\quad 111$

9.1.1 Economie 111

9.1.2 Nutriëntenoverschot en organische stof $\quad 112$

9.1.3 Broeikasgasemissies 114

9.1.4 Bodemgezondheid 114

9.1.5 Overige bedrijfsaspecten 115

9.2 Klimaatrisico's $\quad 115$

9.2.1 Eiwitgewassen $\quad 115$

$\begin{array}{ll}9.2 .2 \text { Bouwplannen } & 116\end{array}$

$\begin{array}{lll}9.3 & \text { Integraal beeld en conclusies/adviezen } & 117\end{array}$ 
Bijlage 1 Deelnemers regiogesprekken

Bijlage 2 Definities afkortingen klimaatfactoren

Bijlage 3 Emissies melkkoeien 129

Bijlage $4 \quad \mathrm{~N}$ benutting excretie melkkoeien 131

Bijlage 5 Voerverbruik jongvee 133

Bijlage 6 Rantsoen melkkoeien 135

Bijlage 7 Ruwvoerverbruik melkkoeien 137

Bijlage 8 Melkproductie 139 



\section{Woord vooraf}

Dit rapport beschrijft de resultaten van de PPS-projecten "Bouwplannen onder eiwittransitie en klimaatverandering" en "Optimalisering gezamenlijk grondgebruik akkerbouw en melkveehouderij". Omdat beide projecten sterke raakvlakken hebben, met name wat betreft de bouwplanberekeningen, zijn ze in gezamenlijk verband uitgevoerd en zijn de resultaten in één rapport weergegeven.

Het onderzoek is aangestuurd door een begeleidingscommissie met daarin vertegenwoordigers van Brancheorganisatie Akkerbouw, ZuiveINL, LTO, NAV, NMV en LNV. Op deze plaats willen we leden van de begeleidingscommissie bedanken voor de feedback die we hebben gekregen.

Tenslotte willen we Sjaak Conijn (WPR) bedanken voor zijn bijdragen aan de organische stofberekeningen en Jakob Jager en Bert Smit (beide WEcR) voor het beschikbaar stellen van gegevens over de structuur van melkveebedrijven in Nederland.

De auteurs 


\section{Samenvatting}

In de periode 2019-2020 zijn een tweetal projecten uitgevoerd die zicht richtten op de effecten van verandering van bouwplannen op akkerbouw- en melkveebedrijven. Het project "Bouwplannen onder klimaatverandering en eiwittransitie" had tot doel de kennis over klimaatverandering en teelt van eiwitgewassen te inventariseren en de effecten van bouwplanaanpassingen in kaart te brengen. In het project "Optimalisering gezamenlijk grondgebruik akkerbouw en melkveehouderij" is gekeken hoe gezamenlijk grondgebruik tussen akkerbouw- en melkveebedrijven kan worden verbeterd. Omdat beide projecten sterke raakvlakken hebben, met name wat betreft de bouwplanberekeningen, zijn ze in gezamenlijk verband uitgevoerd. Dit rapport beschrijft de resultaten van beide projecten.

\section{Globale aanpak}

\section{Effecten gezamenlijk grondgebruik en teelt van eiwitgewassen}

Op basis van interviews met experts en beschikbare kennis en data zijn huidige bouwplannen (referentie) in kaart gebracht voor zowel akkerbouw als melkveehouderij in vier regio's: NoordoostNederland (NON, zand/dal), Zuidoost-Nederland (ZON, zand), Centraal-Nederland (CEN, klei) en Zuidwest-Nederland (ZWN, klei). Tabel S1 geeft een indruk van de referentiebouwplannen.

In de gekozen regio's is het al gewoon om grond te ruilen tussen akkerbouw- en melkveehouderijbedrijven. Het economisch bouwplan betreft de gewassen die op naam staan van de melkveehouder of akkerbouwer, het percelenbouwplan betreft de gewassen die op grond van de melkveehouder of de akkerbouwer worden geteeld. Bij de grondruil is in drie van de vier regio's (NON, ZON en ZWN) uitgegaan van uitruil van maïs en aardappelen (rode kolommen in Tabel S1), terwijl in één regio (CEN) gras wordt geruild met aardappel. Door de grondruil kan de akkerbouwer meer aardappelen verbouwen en de melkveehouder kan tegelijkertijd zijn gras vernieuwen.

Tabel S1 Overzicht referentiebouwplannen (\%, zowel economische bouwplan als het percelenbouwplan op de grond van het bedrijf) op het akkerbouw- en melkveebedrijf in de vier regio's. De vetroodgedrukte arealen geven de uitgeruilde gewassen aan.

\begin{tabular}{|c|c|c|c|c|c|c|c|c|c|c|c|c|c|c|}
\hline \multirow{3}{*}{$\begin{array}{l}\text { Bedrijf: } \\
\text { Bouwplan: } \\
\text { Regio Igewas: }\end{array}$} & \multicolumn{6}{|c|}{ Akkerbouw } & \multicolumn{8}{|c|}{ Melkveehouderij } \\
\hline & \multicolumn{2}{|c|}{ Economisch } & \multicolumn{4}{|c|}{ Percelen } & \multicolumn{3}{|c|}{ Economisch } & \multicolumn{5}{|c|}{ Percelen } \\
\hline & Aard & Akk,overig & Aard & Akk, overig & TG & Maïs & BG & TG & Maïs & BG & TG & Maïs & Aard & Tulp \\
\hline NON & 60 & 40 & 50 & 40 & & 10 & 40 & 40 & 20 & 40 & 40 & 10 & 10 & \\
\hline ZON & 35 & 65 & 25 & 65 & & 10 & 20 & 60 & 20 & 20 & 60 & 10 & 10 & \\
\hline CEN & 43 & 57 & 33 & 57 & 10 & & 20 & 60 & 20 & 20 & 40 & 20 & 10 & 10 \\
\hline ZWN & 35 & 65 & 25 & 65 & & 10 & 30 & 50 & 20 & 30 & 50 & 10 & 10 & \\
\hline
\end{tabular}

$\mathrm{TG}=$ tijdelijk grasland; $\mathrm{BG}=$ blijvend grasland .

Vervolgens zijn voor elk van de regio's bouwplanvarianten met betrekking tot gezamenlijk grondgebruik vastgesteld en de teelt van eiwitgewassen doorgerekend en beoordeeld op agronomische effecten (o.a. economie, bodemgezondheid, organische stof) en milieutechnische effecten (nutriëntenoverschotten en broeikasgasemissies).

\section{Effecten verandering klimaat}

Om de risico's van specifieke weersomstandigheden (klimaatfactoren, o.a. droogte, hoge temperaturen, vorst) in kaart te brengen, is gebruik gemaakt van de klimaatstresstest. De kans van het optreden van deze klimaatfactoren in de toekomst is gebaseerd op klimaatscenario's van het KNMI voor de periode 2035-2065. De specifieke omstandigheden waaronder opbrengstderving optreedt, zijn afhankelijk van het gewas in kwestie, teeltomstandigheden en de periode van voorkomen. Voor diverse gewassen is een expertinschatting gemaakt van de kwetsbaarheden en de verwachte 
opbrengstderving bij optreden van de klimaatfactoren. Het risico op schade wordt berekend door de kans van het optreden van klimaatfactoren (frequentie) te vermenigvuldigen met de impact op het gewas. Door deze bij de huidige klimaatomstandigheden op 100 te stellen kan het relatieve effect van klimaatfactoren bij een bepaald klimaatscenario worden bepaald.

\section{Resultaten}

\section{Gezamenlijk grondgebruik}

Bouwplanvarianten die zijn verkend zijn een verhoogd aandeel blijvend grasland op het melkveebedrijf (NON, CEN en ZON), een ruimere teeltfrequentie van aardappelen op het akkerbouwbedrijf (NON) en een volledige integratie van de bouwplannen over het akkerbouw- en melkveehouderijbedrijf (NON). In Tabel S2 is aangegeven welke effecten deze bouwplanaanpassingen hebben op verschillende bedrijfsaspecten.

Bij grondruil is er doorgaans meer tijdelijk grasland in wisselbouw met bouwlandgewassen. Het integreren van grasland met akkerbouw is gunstig voor de organisch stofvoorziening van het bouwland. Om trade-offs te voorkomen is bij de inrichting van de wisselbouw het volgende van belang:

- Uit oogpunt van bodemgezondheid (o.a. ritnaalden) en risico van N-verliezen heeft het kiezen voor korte grasperiodes (maximaal 2-3 jaar oud) de voorkeur. Afhankelijk van de vormgeving van de rotatie kan dit leiden tot hogere herinzaaikosten. De berekeningen hebben echter laten zien dat, indien het aandeel blijvend grasland zo hoog mogelijk wordt gehouden, de kosten beperkt zijn.

- In de bouwlandperiode is het van belang dat er na het scheuren van het gras een gewas wordt geteeld met een hoge $\mathrm{N}$-behoefte (bijvoorbeeld voederbieten, consumptie- en zetmeelaardappelen en maïs) en dat de $\mathrm{N}$-bemesting wordt aangepast aan de te verwachten nalevering uit de gescheurde zode (circa $100 \mathrm{~kg} \mathrm{~N}$ per ha). Om de risico's van N-verliezen verder te beperken zou bij voorkeur ook nog een vanggewas moeten worden gezaaid

Een aandachtspunt rond organische stof is de verhouding blijvend en tijdelijk grasland. Uit de berekeningen bleek dat, bij een gelijkblijvend aandeel gras in het bouwplan en een gelijkblijvend mestgebruik, de verhouding blijvend en tijdelijk grasland geen groot effect heeft op de totale EOSaanvoer. Het is op dit moment lastig om aan te geven welke gevolgen het heeft voor de koolstofopslag in de bodem.

Een volledige integratie van het akkerbouw- en melkveehouderijbouwplan, zoals verkend voor NON, biedt het voordeel dat een hoog aardappelareaal kan worden gehandhaafd, terwijl de teeltfrequentie lager wordt. Wel stijgen de herinzaaikosten van het gras doordat er alleen nog maar tijdelijk gras aanwezig is. Ook stijgen de broeikasgasemissies doordat vaker opnieuw gras moet worden ingezaaid.

Uit de studie blijkt dat bij gezamenlijk grondgebruik veel bedrijfsaspecten een rol spelen. Dit vereist een goede voorbereiding bij het opzetten van de samenwerking en met name de vruchtopvolging dient goed doordacht te worden. Voor de akkerbouwer verdienen vooral bodemgezondheidsaspecten de aandacht, met name bij de teelt van gewassen voor de export. Hierbij is naast de teeltfrequentie vooral ook de gewasvolgorde van belang. Kennis van de in een perceel aanwezige bodemziekten en plagen is noodzakelijk om een slimme gewasvolgorde te bepalen.

\section{Teelt van alternatieve (eiwit) gewassen}

In tabel S2 zijn de verschillende varianten weergegeven. De teelt van eiwitgewassen is op het akkerbouwbedrijf verkend via de teelt van zaadleguminosen (veldbonen, erwten en soja) in plaats van graan. Op melkveebedrijven is gekeken naar vervanging van tijdelijk grasland door gras rode klaver en vervanging van de helft van de maïs door MKS (maïskolvenschroot), veldbonen, voederbieten of wintergerst.

De teelt van zaadleguminosen op akkerbouwbedrijven is op dit moment economisch ongunstiger dan graan, vooral als gevolg van een lagere financiële opbrengst. Wel geeft het een verlaging van het kunstmest-N-gebruik en het $\mathrm{N}$-overschot en zijn de broeikasgasemissies lager. De gevolgen voor de organische stofvoorziening zijn relatief gering. De risico's voor bodemgezondheid zijn hoger bij teelt van vlinderbloemigen. 
Op melkveebedrijven was de teelt van gras-rode klaver (in plaats van tijdelijk grasland) economisch gunstiger dan de teelt van veldbonen (in plaats van een deel van de maïs). Gras-rode klaver leidt tot een sterkere verlaging van het kunstmest- $\mathrm{N}$-gebruik en sterkere daling van de broeikasgasemissies.

Vervanging van een deel van de maïs door voederbieten is economisch gunstiger dan vervanging van maïs door veldbonen. Ook de broeikasgasemissies waren lager indien de maïs werd vervangen door voederbieten door de besparing op aangekocht mengvoer. Ook vervanging van maïs door MKS bleek op veel aspecten een gunstig effect te hebben.

Tabel S2 Overzicht van effecten van bouwplanaanpassingen op verschillende bedrijfsaspecten van een melkveehouder (MVH) en akkerbouwer (AKK).

\begin{tabular}{|c|c|c|c|c|c|c|c|c|c|c|}
\hline \multirow{2}{*}{ Scenario } & \multicolumn{2}{|c|}{\begin{tabular}{|l|} 
Economisch \\
boumplan
\end{tabular}} & \multicolumn{2}{|c|}{$\begin{array}{l}\text { Risico N- } \\
\text { veliezen } \\
\text { (uitspoeding) }\end{array}$} & \multicolumn{2}{|c|}{ BKG-emissies } & \multicolumn{2}{|c|}{$\begin{array}{l}\text { Aanvoer } \\
\text { effectieve } \\
\text { organische stof }\end{array}$} & \multicolumn{2}{|c|}{$\begin{array}{l}\text { Bodem- } \\
\text { gezondheid }\end{array}$} \\
\hline & MVH & AKK & MVH & AKK & MVH & AKK & MVH & AKK & MVH & AKK \\
\hline \multicolumn{11}{|l|}{ Gezamenlijk grondgebruik } \\
\hline \multirow{2}{*}{\multicolumn{11}{|c|}{$\begin{array}{l}\text { Meer blijvend grasland } \\
\text { Ruimere teeltfrequentie akkerbouw } \\
\text { Volledige integratie bouwplannen AKK en MVH }\end{array}$}} \\
\hline & & & & & & & & & & \\
\hline \multicolumn{11}{|c|}{ Vervangen mais/gras door andere (eiwt)gewassen MVH } \\
\hline \multirow{5}{*}{\multicolumn{11}{|c|}{$\begin{array}{l}\text { Gras rode klaver i.p.v. gras MVH } \\
\text { Veldboon i.p.v. mais MVH } \\
\text { Voederbiet i.p.v. gras of mais MVH } \\
\text { MKS i.p.v. mais MVH } \\
\text { Wintergerst i.p.v. mais MVH }\end{array}$}} \\
\hline & & & & & & & & & & \\
\hline & & & & & & & & & & \\
\hline & & & & & & & & & & \\
\hline & & & & & & & & & & \\
\hline \multicolumn{11}{|c|}{ Vervangen graan/mais door andere (eiwit)gewassen AKK } \\
\hline $\begin{array}{l}\text { Wintergerst i.p.v. mais AKK } \\
\text { Erwten i.p.v. wintertarwe AKK } \\
\text { Veldbonen i.p.v. wintertarwe AKK } \\
\text { Soja i.p.v. wintertarwe AKK }\end{array}$ & & & & & & & & & & \\
\hline
\end{tabular}

Ten opzichte van referentie

\begin{tabular}{|} 
Ten opzichte van referentie \\
\begin{tabular}{|l|l}
\hline \\
Beter \\
Gelijk \\
Slechter \\
Zowel beter als slechter
\end{tabular} \\
\hline
\end{tabular}

\section{Klimaatverandering}

De gevolgen van toenemende frequenties in hittegolven, droogte en warm en nat weer zijn het grootst voor aardappel en ui. Bij winterpeen en gras zijn de risico's geringer, terwijl bij maïs, wintertarwe en suikerbiet de effecten soms positief zijn en soms negatief. Dit betekent dat bij bouwplannen met een hoog aandeel aardappelen en uien de gevolgen van klimaatverandering het grootst zijn.

Eiwitgewassen (zaadleguminosen) hebben voornamelijk meer last van droogte en hitte. De frequenties daarvan, en daarmee de risico's, gaan in de toekomst toenemen. De risico's van vorst in het voorjaar en natte periodes tijdens de bloei nemen af, waardoor de teeltomstandigheden verbeteren. Door de hogere frequentie van buien met hevige neerslag kunnen de gewassen wel meer last krijgen van water op het land of legering. 


\section{$1 \quad$ Inleiding}

\section{$1.1 \quad$ Aanleiding}

Een tweetal ontwikkelingen kunnen de komende decennia grote invloed hebben op de samenstelling van het bouwplan in de Nederlandse akkerbouw en ruwvoederproductie: klimaatverandering en de eiwittransitie. Klimaatverandering brengt extremere weersomstandigheden (bijvoorbeeld te nat en te droog) met zich mee en de gewenste eiwittransitie vraagt om een hoger aandeel vlinderbloemigen in het bouwplan. De consequenties van de bovengenoemde ontwikkelingen op het bouwplan en de vruchtwisseling en vervolgens op bodemkwaliteit en bouwplansaldo zijn vooralsnog onduidelijk. Kennis hierover kan de sector helpen om beter gefundeerde strategische keuzes te maken.

Daarnaast is het de vraag in hoeverre samenwerking tussen akkerbouw- en melkveebedrijven, in het bijzonder gezamenlijk grondgebruik, beide sectoren kan helpen om tot een duurzame bedrijfsvoering te komen. In veel landbouwregio's in Nederland wordt er samengewerkt tussen akkerbouwers en melkveehouders, waarbij grondruil vaak onderdeel is van de samenwerking. Vaak leidt dit er toe dat grasland en akkerbouwgewassen gaan mee roteren in de vruchtwisseling op beide bedrijven. Recente projecten op dit gebied laten zien dat er verbeteringen mogelijk zijn in het grondgebruik in de samenwerking. Hierdoor kan bijvoorbeeld een hoger aandeel blijvend grasland worden gehandhaafd en kunnen ook de risico's van stikstofverliezen worden beperkt. Uit eerdere projecten blijkt ook dat de risico's voor de bodemgezondheid onvoldoende worden onderkend.

\subsection{Doel en afbakening}

Om bovenstaande vragen te beantwoorden zijn een tweetal projecten uitgevoerd.

- Het PPS-project "Bouwplannen onder klimaatverandering en eiwittransitie" heeft als doel bestaande kennis met betrekking tot klimaatverandering en eiwittransitie te inventariseren en de effecten van bouwplanaanpassingen in kaart te brengen.

- Het PPS-project "Optimalisering gezamenlijk grondgebruik akkerbouw en melkveehouderij" heeft als doel aan te geven hoe het gezamenlijk grondgebruik kan worden verbeterd door verschillende grondgebruiksvarianten door te rekenen.

Omdat beide projecten sterke raakvlakken hebben, met name wat betreft de bouwplanberekeningen, zijn ze in gezamenlijk verband uitgevoerd.

\section{Afbakening}

- De projecten richten zich op de effecten van bouwplanveranderingen op de economie (bouwplansaldo), nutriënten en organische stofbeheer, bodemgezondheid en broeikasgasemissies. $\mathrm{Er}$ is niet specifiek stilgestaan bij andere aspecten van de bedrijfsvoering zoals de onkruidbeheersing.

- Bij de berekeningen zijn geen varianten meegenomen met oogst van vanggewassen t.b.v. ruwvoer. Dergelijke varianten zijn al doorgerekend in de PPS Ruwvoer \& Bodem en staan beschreven in Van Dijk et al. (2020).

\subsection{Aanpak}

Het onderzoek is gericht op het verkennen van de mogelijkheden tot het verhogen van de productie van eiwitten, voor mens en dier, in Nederland. Daarnaast is nagegaan hoe het gezamenlijk grondgebruik kan worden verbeterd. Hierbij is de volgende globale aanpak gehanteerd. Op basis van interviews met experts en beschikbare kennis en data zijn huidige bouwplannen in kaart gebracht voor zowel akkerbouw als melkveehouderij in 4 regio's: Centrale zeeklei, Zuidwestelijk zeeklei, Zuidoostelijk zandgebied en Noordoostelijk zandgebied. Vervolgens zijn voor elk van de regio's 
bouwplanvarianten met betrekking tot teelt van meer eiwit en gezamenlijk grondgebruik vastgesteld en beoordeeld op agronomische (o.a. economie, bodemgezondheid, organische stof) en milieutechnische effecten. Daarnaast is een kennisinventarisatie uitgevoerd met betrekking tot de risico's van klimaatverandering en effecten van eiwitproductie (op o.a. bodempathogenen). Die bevindingen, conclusies en aanbevelingen zijn samengebracht in dit rapport.

\subsection{Leeswijzer}

In hoofdstuk 2 wordt een overzicht gegeven van de eiwitproductie van diverse gewassen. In hoofdstuk 3 zijn de resultaten van de kennisinventarisatie met betrekking tot de gevolgen van

klimaatveranderingen, met focus op weersextremen en mogelijke gevolgen voor gewasopbrengsten, in beeld gebracht. In hoofdstuk 4 wordt de invloed van de teelt van vlinderbloemigen op bodempathogenen en -plagen en de mogelijke risico's daarbij benoemd. In hoofdstuk 5 worden vervolgens de huidige bouwplannen in de akkerbouw en melkveehouderij en varianten met betrekking tot gezamenlijk grondgebruik en de teelt van meer eiwit beschreven met een toelichting op gewaskeuzes en vruchtopvolging. In hoofdstuk 6 zijn de uitgangspunten van de bouwplanberekeningen gegeven, waarna in hoofdstuk 7 de resultaten worden besproken. In hoofdstuk 8 worden de resultaten bediscussieerd. Tenslotte vindt er in hoofdstuk 9 een synthese plaats van de resultaten om zodoende tot een integraal beeld te komen en eventuele trade-offs zichtbaar te maken. 


\section{Eiwittransitie}

\section{$2.1 \quad$ Inleiding}

Met de term eiwittransitie wordt hier bedoeld een verhoogde lokale teelt van eiwit (in plaats van geïmporteerd) en een verandering in consumptiepatroon naar een dieet met een hoger aandeel plantaardig eiwit (voor mens en dier). Meer lokale productie van eiwit draagt bij aan grondgebondenheid in de veehouderijsector. In haar toekomstvisie geeft de melkveehouderijsector aan dat $65 \%$ van de eiwitbehoefte van eigen grond moet komen, of afkomstig moet zijn uit de directe omgeving, bijvoorbeeld van nabije akkerbouwers. Hierdoor is er een groot belang om eiwitrijke gewassen te telen. Deze transitie vraagt om een hogere productie van vlinderbloemigen in de Nederlandse landbouw, hetgeen een hoger aandeel vlinderbloemigen in het bouwplan vraagt.

\subsection{Eiwitopbrengst gewassen}

De eiwittransitie vereist dat meer eiwitrijke gewassen (voor menselijke en dierlijke consumptie) in een bouwplan worden opgenomen. Dit kan bereikt worden door de teelt van gewassen met een hoog eiwitgehalte, zoals zaadleguminosen (o.a. veldbonen, erwten, lupine en sojabonen) of ruwvoergewassen met een hoger eiwitgehalte zoals gras, grasklaver en luzerne. De eiwitopbrengst van deze gewassen en veel geteelde andere gewassen in de huidige bouwplannen op akkerbouw- en melkveebedrijven zijn gepresenteerd in Tabel 2.1 met een gemiddelde en een hoge opbrengst. Hieruit blijkt dat gewassen met een hoog eiwitgehalte (ruw eiwit) niet altijd de hoogste totale eiwitopbrengst per ha leveren. Hierbij moet wel worden benadrukt dat bij gewassen, zoals veldbonen en sojabonen, er nog ontwikkeling in opbrengst mogelijk is in de toekomst o.a. door veredeling en verbetering van teelttechniek.

Tabel 2.1 Overzicht van vaak geteelde gewassen met opbrengst (gemiddelde en hoog), ruw eiwit en ruw eiwit opbrengst per ha (op basis van CVB, 2018, KWIN 2018 en expert inschatting).

\begin{tabular}{|c|c|c|c|c|c|c|c|c|c|}
\hline Gewas & $\begin{array}{l}\text { DS } \\
(\%)\end{array}$ & $\begin{array}{l}\text { RE } \\
\text { (ruw } \\
\text { eiwit) }\end{array}$ & Eenheid & DVE & $\begin{array}{l}\text { Opbrengst } \\
\mathrm{kg} / \mathrm{Ha}\end{array}$ & Eenheid & $\begin{array}{l}\text { Ruw Eiwit } \\
\text { opbrengst } \\
\text { (kg/ha) }\end{array}$ & $\begin{array}{l}\text { Hoge } \\
\text { opbrengst }\end{array}$ & $\begin{array}{l}\text { Ruw Eiwit } \\
\text { hoge } \\
\text { opbrengst } \\
\text { (kg/ha) }\end{array}$ \\
\hline Consumptieaardappelen & 260 & 41 & $\mathrm{~g} / \mathrm{kg} \mathrm{DS}$ & 69 & 52000 & $\mathrm{~kg} / \mathrm{Ha}$ & 554 & 80000 & 853 \\
\hline Wintertarwe & 859 & 110 & $\mathrm{~g} / \mathrm{kg}$ & 100 & 8500 & $\mathrm{~kg} / \mathrm{Ha}$ & 935 & 11000 & 1210 \\
\hline Uien & 118 & 135 & $\mathrm{~g} / \mathrm{kg} \mathrm{DS}$ & 76 & 40000 & $\mathrm{~kg} / \mathrm{Ha}$ & 637 & 60000 & 956 \\
\hline Peen & 112 & 82 & $\mathrm{~g} / \mathrm{kg} \mathrm{DS}$ & 94 & 85000 & $\mathrm{~kg} / \mathrm{Ha}$ & 781 & 110000 & 1010 \\
\hline Suikerbiet & 260 & 41 & $\mathrm{~g} / \mathrm{kg} \mathrm{DS}$ & 77 & 80000 & $\mathrm{~kg} / \mathrm{Ha}$ & 853 & 110000 & 1173 \\
\hline Zomergerst & 867 & 100 & $\mathrm{~g} / \mathrm{kg}$ & 101 & 7000 & $\mathrm{~kg} / \mathrm{Ha}$ & 700 & 8000 & 800 \\
\hline Snijmaïs vers & 225 & 94 & $\mathrm{~g} / \mathrm{kg}$ DS & 47 & 15500 & $\mathrm{~kg} \mathrm{DS} / \mathrm{Ha}$ & 1457 & & \\
\hline Gras vers & 163 & 227 & $\mathrm{~g} / \mathrm{kg} \mathrm{DS}$ & 75 & 12600 & kg DS/Ha & 2860 & & \\
\hline Grasklaver & 370 & 195 & $\mathrm{~g} / \mathrm{kg}$ DS & 80 & 14100 & $\mathrm{~kg} \mathrm{DS} / \mathrm{Ha}$ & 2750 & & \\
\hline Luzerne vers & 201 & 210 & $\mathrm{~g} / \mathrm{kg} \mathrm{DS}$ & 70 & 14000 & $\mathrm{~kg} \mathrm{DS} / \mathrm{Ha}$ & 2940 & & \\
\hline Bonen (Phaseolus) & 862 & 229 & $\mathrm{~g} / \mathrm{kg}$ & 105 & 3350 & $\mathrm{~kg} / \mathrm{Ha}$ & 767 & 4500 & 1031 \\
\hline Veldbonen, witbloeiend & 880 & 286 & $\mathrm{~g} / \mathrm{kg}$ & 119 & 4500 & $\mathrm{~kg} / \mathrm{Ha}$ & 1287 & 8000 & 2288 \\
\hline Erwten (droog) & 866 & 203 & $\mathrm{~g} / \mathrm{kg}$ & 98 & 6000 & $\mathrm{~kg} / \mathrm{Ha}$ & 1218 & 8000 & 1624 \\
\hline Lupine & 908 & 314 & $\mathrm{~g} / \mathrm{kg}$ & 130 & 1900 & $\mathrm{~kg} / \mathrm{Ha}$ & 597 & 4000 & 1256 \\
\hline Sojabonen & 897 & 363 & $\mathrm{~g} / \mathrm{kg}$ & 111 & 1900 & $\mathrm{~kg} / \mathrm{Ha}$ & 690 & 4000 & 1452 \\
\hline
\end{tabular}


De getallen in Tabel 2.1 laten de mogelijke eiwitopbrengst van verschillende gewassen zien. Hierbij valt op De eiwitopbrengst van zaadleguminosen (o.a. veldbonen, erwten) is bij gemiddelde

opbrengsten lager dan bij andere eiwitrijke gewassen als gras en luzerne. In de praktijk zal het ruw eiwitgehalte en de opbrengst afhankelijk zijn van de groeiomstandigheden en rassenkeuze. Hierdoor zullen sommige gewassen in de praktijk beter of slechter presteren. De gewassen in Tabel 2.1 zijn een aantal kansrijke soorten. Er zijn echter meer mogelijkheden: hennepzaad, boekweit, quinoa, linzen, hazelnoot en walnoot zouden in de toekomst verkend kunnen worden. 


\section{$3 \quad$ Klimaatverandering}

\subsection{Achtergrond en introductie}

In 2018 hadden boeren te maken met één van de droogste zomers sinds het begin van de waarnemingen en in 2019 werd na 75 jaar het nationale hitterecord van $39,3{ }^{\circ} \mathrm{C}$ verbroken. Het is te verwachten dat zulke extreme weersomstandigheden door klimaatverandering vaker zullen voorkomen. Met klimaatmodellen kunnen we de extremen kwantificeren en hun frequentie inschatten. Op basis van de verwachte weersomstandigheden kunnen we ook effecten op en verschillen tussen gewassen inschatten. Op basis hiervan kunnen we voorspellen welke gewassen in de toekomst meer of minder aantrekkelijk zullen zijn.

Klimaat is de gemiddelde toestand van onder andere temperatuur, neerslag en wind over een 30 jaar durende periode. Klimaatverandering is het gevolg van opwarming van de aarde, waardoor de gemiddelde temperatuur, neerslag en wind verandert. Hoe sterk het klimaat verandert is afhankelijk van de uitstoot van broeikasgassen in de komende jaren. Als we de uitstoot van broeikasgassen kunnen verminderen, zal de globale temperatuur minder stijgen. Als we daarentegen de uitstoot niet verminderen, zal de temperatuur verder stijgen. Om deze verschillende mogelijkheden te laten zien, zijn meerdere scenario's ontwikkeld waarin de temperatuur meer of minder stijgt.

Het Koninklijk Nederlands Meteorologisch Instituut (KNMI) heeft vier klimaatscenario's ontwikkeld (Klein Tank, Beersma, Bessembinder, van den Hurk, \& Lenderink, 2015). Deze scenario's zijn $\mathrm{GL}_{\mathrm{L}} \mathrm{G}_{\mathrm{H}}$, $W_{L}$ en $W_{H}$. De vier scenario's laten vier mogelijke uitwerkingen zien van klimaatverandering op basis van een temperatuurstijging van $1^{\circ} \mathrm{C}$ of $2^{\circ} \mathrm{C}$ en een hoge $(H)$ of een lage verandering $(L)$ in luchtcirculatie, zie Figuur 3.1. In de Gematigde $(G)$ scenario's wordt uitgegaan van een wereldwijde temperatuurstijging van $1^{\circ} \mathrm{C}$ in 2050 en $1,5^{\circ} \mathrm{C}$ in 2085 (ten opzichte van 1981-2010). In het Warme (W) scenario is er een stijging van $2^{\circ} \mathrm{C}$ in 2050 en $3,5^{\circ} \mathrm{C}$ in 2085 (ten opzichte van 1981-2010). In de varianten $\left(G_{L}\right.$ en $W_{L}$ ) is er een kleine verandering van het luchtstromingspatroon en in de hoge varianten $\left(\mathrm{G}_{\mathrm{H}}\right.$ en $\mathrm{W}_{\mathrm{H}}$ ) is er een grote verandering (Klein Tank et al., 2015).

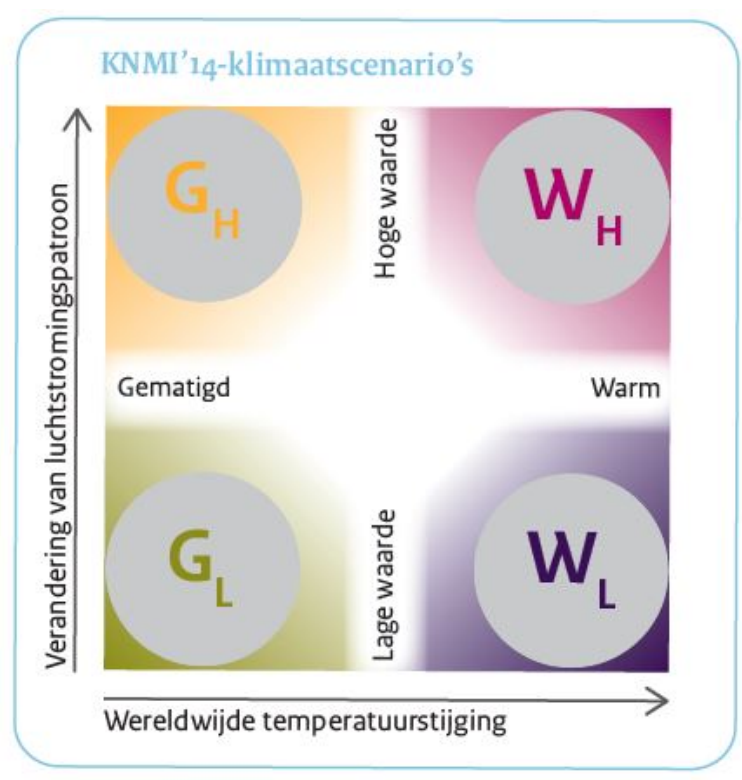

Figuur 3.1 KNMI'14 Klimaatscenario's (Klein Tank et al., 2015). 
Deze scenario's worden gebruikt om lokale weersveranderingen (temperatuur, neerslag, etc.) te simuleren met behulp van General Circulation Modellen (GCM) en Regional Climate Modellen (RCM). Hierdoor krijgen we inzicht in de verandering in lokale weersomstandigheden. In 2030 zal het effect van klimaatverandering in de vier scenario's vrij verglijkbaar zijn. Tabel $\mathbf{3 . 2}$ geeft de verwachte verandering in het klimaat in Nederland rond 2030 weer. Hier zien we dat de temperatuur stijgt met als gevolg zachte winters en hete zomers en een toename van de totale en extreme neerslag. Tegelijkertijd is de verdamping hoger en de kans van neerslagtekort in het groeiseizoen neemt ook toe.

Tabel 3.1 De gemiddelde verwachte verandering in klimaat rond 2030 in vergelijking met de referentieperiode, 1981-2010 (Klein Tank et al., 2015).

\begin{tabular}{|c|c|c|c|c|}
\hline Seizoen ${ }^{A)}$ & Variabele & Indicator & $\begin{array}{l}\text { Klimaat }^{\mathrm{B})} \\
1981-2010 \\
=\text { referentie- } \\
\text { periode }\end{array}$ & $\begin{array}{l}\text { Gemiddelde } \\
\text { verandering } \\
\text { voor het } \\
\text { klimaat rond } \\
2030^{\circ} \\
(2016-2045)\end{array}$ \\
\hline \multirow[t]{7}{*}{ Jaar } & \multirow{2}{*}{$\begin{array}{l}\text { Zeespiegel bij } \\
\text { Noordzeekust }\end{array}$} & absolute niveau ${ }^{\text {) }}$ & $3 \mathrm{~cm}$ boven NAP & +10 tot $+25 \mathrm{~cm}$ \\
\hline & & tempo van verandering & $\begin{array}{r}2,0 \mathrm{~mm} / \\
\text { jaar }\end{array}$ & $\begin{array}{r}+1 \text { tot }+6 \mathrm{~mm} / \\
\text { jaar }\end{array}$ \\
\hline & Temperatuur & gemiddelde & $10,1^{\circ} \mathrm{C}$ & $+1,0^{\circ} \mathrm{C}$ \\
\hline & Neerslag & gemiddelde hoeveelheid & $851 \mathrm{~mm}$ & $+5 \%$ \\
\hline & Zonnestraling & zonnestraling & $354 \mathrm{~kJ} / \mathrm{cm}^{2}$ & $+0,2 \%$ \\
\hline & Verdamping & potentiële verdamping (Makkink) & $559 \mathrm{~mm}$ & $+2,5 \%$ \\
\hline & Mist & aantal uren met zicht minder dan $1 \mathrm{~km}$ & 300 uur $^{G}$ & -100 uur \\
\hline \multirow[t]{7}{*}{ Winter } & Temperatuur & gemiddelde & $3,4^{\circ} \mathrm{C}$ & $+1,2^{\circ} \mathrm{C}$ \\
\hline & \multirow[t]{3}{*}{ Neerslag } & gemiddelde hoeveelheid & $211 \mathrm{~mm}$ & $+8,5 \%$ \\
\hline & & 10-daagse neerslagsom die eens in de 10 jaar wordt overschreden ${ }^{17}$ & $89 \mathrm{~mm}$ & $+9 \%$ \\
\hline & & aantal natte dagen ( $\geq 0,1 \mathrm{~mm}$ ) & 55 dagen & $+1,5 \%$ \\
\hline & \multirow[t]{3}{*}{ Wind } & gemiddelde windsnelheid & $6,9 \mathrm{~m} / \mathrm{s}$ & $+0,5 \%$ \\
\hline & & hoogste daggemiddelde windsnelheid per jaar & $15 \mathrm{~m} / \mathrm{s}$ & $-1,0 \%$ \\
\hline & & aantal dagen met windrichting tussen zuid en west & 49 dagen & $+2,5 \%$ \\
\hline \multirow[t]{2}{*}{ Lente } & Temperatuur & gemiddelde & $9,5^{\circ} \mathrm{C}$ & $+0,8^{\circ} \mathrm{C}$ \\
\hline & Neerslag & gemiddelde hoeveelheid & $173 \mathrm{~mm}$ & $+5,5 \%$ \\
\hline \multirow[t]{9}{*}{ Zomer } & Temperatuur & gemiddelde & $17,0^{\circ} \mathrm{C}$ & $+0,9^{\circ} \mathrm{C}$ \\
\hline & \multirow[t]{4}{*}{ Neerslag } & gemiddelde hoeveelheid & $224 \mathrm{~mm}$ & $+0,2 \%$ \\
\hline & & dagelijkse hoeveelheid die eens in de 10 jaar wordt overschreden" & $44 \mathrm{~mm}$ & $+1,7$ tot $+10 \%$ \\
\hline & & maximum uurneerslag per jaar & $15,1 \mathrm{~mm} / \mathrm{uur}$ & $+5,5$ tot $+11 \%$ \\
\hline & & aantal natte dagen ( $\geq 0,1 \mathrm{~mm})$ & 43 dagen & $+0,5 \%$ \\
\hline & Zonnestraling & zonnestraling & $153 \mathrm{~kJ} / \mathrm{cm}^{2}$ & $+1,9 \%$ \\
\hline & Vochtigheid & relatieve vochtigheid & $77 \%$ & $-0,6 \%$ \\
\hline & Verdamping & potentiële verdamping (Makkink) & $266 \mathrm{~mm}$ & $+3,5 \%$ \\
\hline & Droogte & gemiddeld hoogste neerslagtekort gedurende het groeiseizoen? & $144 \mathrm{~mm}$ & $+4 \%$ \\
\hline \multirow[t]{2}{*}{ Herfst } & Temperatuur & gemiddelde & $10,6^{\circ} \mathrm{C}$ & $+1,0^{\circ} \mathrm{C}$ \\
\hline & Neerslag & gemiddelde hoeveelheid & $245 \mathrm{~mm}$ & $+5,5 \%$ \\
\hline
\end{tabular}

In 2050 ontstaan er duidelijke verschillen tussen de vier scenario's. Een indruk van het toekomstige weer kan verkregen worden door te kijken naar gebieden waar het huidige weer vergelijkbaar is met het toekomstige klimaat in Nederland. Figuur 3.2 toont gebieden met een winterklimaat dat overeenstemt met het winterklimaat van Amsterdam rond 2050 voor scenario's $G_{L}, G_{H}, W_{L}, W_{H}$. Zo zien we dat in het $\mathrm{W}_{\mathrm{H}}$-scenario het klimaat in Amsterdam (2050) vergelijkbaar is met het huidige klimaat van Nantes of Bordeaux. 


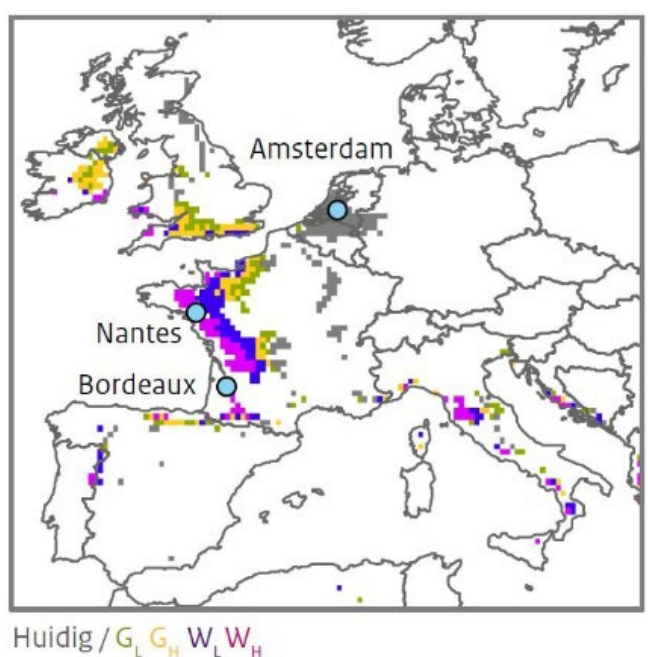

Figuur 3.2 Gebieden met een winterklimaat dat overeenstemt met het verwachte winterklimaat in Amsterdam rond 2050 (Klein Tank et al., 2015).

\subsubsection{Effecten voor de landbouw}

In alle scenario's worden de winter- en zomertemperaturen hoger. Figuur $\mathbf{3 . 3}$ laat zien dat de gemiddelde wintertemperaturen meer dan $2^{\circ} \mathrm{C}$ kunnen stijgen. Deze stijging kan meerdere gevolgen voor boeren hebben. Als positief effect kunnen sommige gewassen in de winter blijven groeien en zullen ze minder winterschade ervaren. Maar een hogere temperatuur betekent ook een grotere kans van overwintering van ziekten, plagen en onkruiden. Bij een afname van vorst in de winter kunnen we meer aardappelopslag verwachten, wat de afgelopen jaren al zichtbaar was. Een hogere temperatuur zal ook leiden tot een verschuiving in het groeiseizoen (zie Figuur 3.3). Nu begint het groeiseizoen rond 10 april, terwijl dit in 2050 een maand vroeger zou kunnen zijn. Met deze verschuiving van het groeiseizoen en vermindering in vorstdagen wordt het mogelijk om gewassen vroeger in het voorjaar te zaaien. Daarnaast biedt het langere groeiseizoen ook kansen voor dubbele teelten (afhankelijk van de waterbeschikbaarheid). Verder zien we dat in de zomer de gemiddelde temperatuur $2{ }^{\circ} \mathrm{C}$ hoger kan zijn. Gewassen met een hoge warmtebehoefte zoals maïs en soja kunnen hiervan profiteren, maar bij andere gewassen kan het leiden tot het snellere gewasontwikkeling en afrijping, waardoor de opbrengst daalt.
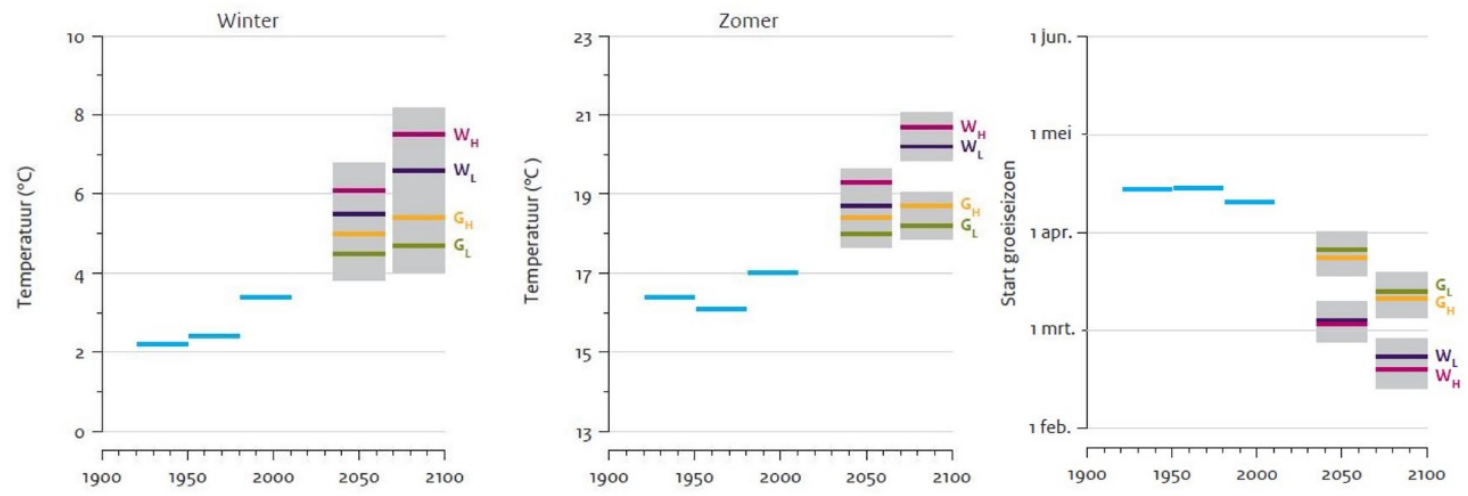

Figuur 3.3 Huidige winter- en zomertemperaturen en toekomstige temperaturen op basis van KNMI'14 scenario's voor De Bilt en start van het groeiseizoen tussen 1900 en 2100 op basis van De Bilt en KNMI'14. Het groeiseizoen begint wanneer de gemiddelde temperatuur boven $5^{\circ} \mathrm{C}$ is en zo blijft tot 1 Juli (Klein Tank et al., 2015). 
In 2050 kunnen we ook een verschuiving verwachten in neerslag, met meer regen in de wintermaanden en minder in de zomer (zie Figuur 3.4). In een warmere en drogere zomer is er kans op het optreden van een neerslagtekort, waardoor opbrengsten lager kunnen uitvallen. Het gemiddelde verschil is niet zo indrukwekkend, met een mogelijke toename van $90 \mathrm{~mm}$ regen in de winter en een afname van $30 \mathrm{~mm}$ in de zomer $\left(W_{H}\right)$. Belangrijk is echter de verandering van de frequenties van weersextremen, zoals hevige regenbuien of aanhoudend natte of droge perioden.


Figuur 3.4 Gemiddelde neerslag in winter en zomer op basis van KNMI'14 scenario's (Klein Tank et al., 2015).

\subsection{Aanpak verkenning risico's teelten voor klimaatverandering}

Weersextremen zoals hittegolven, droogte, overstroming en windstoten kunnen veel schade veroorzaken in de landbouw. Met klimaatverandering kunnen we een toename in weersextremen verwachten, waardoor het risico op opbrengstderving en misoogst hoger zal zijn. Maar het effect van een weersextreem is niet voor alle gewassen gelijk, waardoor de teelt van sommige gewassen meer of minder aantrekkelijk kan worden.

De specifieke omstandigheden waaronder opbrengstderving optreedt, zijn afhankelijk van het gewas in kwestie, teelt omstandigheden en de periode van voorkomen. In de 'Agro Climate Calendar' (Wit de, Swart, \& Luijendijk, 2009) worden de specifieke weersomstandigheden, zoals hittegolven en extreme neerslag (genoemd klimaatfactoren), waaronder opbrengstderving optreedt voor een aantal gangbare akkerbouwgewassen, zoals aardappelen, wintertarwe, suikerbieten, zaaiuien en snijmaïs, in kaart gebracht. Daarbij wordt er per gewas en klimaatfactor een periode van kwetsbaarheid in het teeltseizoen aangewezen, die aangeeft in welke maanden van het jaar/teeltseizoen er schade optreedt. Tevens is de omvang van deze schade aangeduid met een bandbreedte (laag-hoog) als percentage van de geldopbrengst. Pondini (2017) heeft voor deze gewassen en klimaatfactoren de frequentie van optreden in huidig klimaat en toekomstig klimaat berekend, waaruit helder wordt hoe vaak een klimaatfactor nu optreedt en hoe dat in de toekomst gaat veranderen. In dit onderzoek wordt dezelfde aanpak gevolgd om de effecten van klimaatverandering voor eiwitgewassen te verkennen. 
Om bovengenoemde klimaatveranderingen concreet en inzichtelijk te maken op gewasniveau, is een verkenning gedaan naar de risico's en kwetsbaarheden van specifieke eiwitgewassen. In dit onderzoek worden voor een vijftal eiwitgewassen de risico's van klimaatverandering gepresenteerd. Deze vijf gewassen zijn winterveldboon, zomerveldboon, droge erwten, bruine bonen en soja. De belangrijkste vragen zijn:

1. Wat zijn de landbouwkundige en financiële klimaatrisico's van eiwitgewassen?

2. Hoe verhouden de risico's van eiwitgewassen zich tot de klimaatrisico's van huidige gewassen, namelijk: poot- en consumptieaardappelen, wintertarwe, suikerbieten, zaaiuien, grove peen, snijmaïs en gras?

Door deze vragen te beantwoorden, wordt inzicht verkregen in het landbouwkundige en financiële risico van weersextremen door klimaatverandering voor eiwitgewassen. Door tevens andere gewassen mee te nemen, kunnen de risico's van weersextremen van de verschillende gewassen met elkaar worden vergeleken. Hierdoor kan worden afgewogen of en in welke mate andere gewassen in een bouwplan mogelijk kunnen bijdragen aan een reductie van risico's door weersextremen en klimaatverandering. In dit onderzoek zijn niet alle eiwitgewassen meegenomen; zo ontbreken lupine en grasklaver.

\subsubsection{Aanpak}

Om de specifieke impact van weersextremen en klimaatverandering voor eiwitgewassen vast te stellen, zijn een aantal stappen gevolgd. Deze stappen zijn afgeleid van de studies door Schaap, BlomZandstra, Hermans, Meerburg, \& Verhagen (2011) en Verstand, Schaap, Schoorlemmer, de Wolf, e.a. (2020):

Stap 1 tot en met 4 zijn gericht op het in kaart brengen van de kwetsbaarheden en de concrete veranderingen op gewasniveau bij het optreden van klimaatfactoren (weersomstandigheid die in een bepaald gewas schade veroorzaakt; zoals bijvoorbeeld een hittegolf of extreme neerslag). Als deze stappen doorlopen zijn, kan een inschatting van het risico gemaakt worden.

- $\quad$ Stap 1: gesprek met gewasexpert over de grootste schadeposten voor de teelt die te koppelen zijn aan weersomstandigheden en klimaat (klimaatfactoren). Dat wordt gedaan op basis van expertkennis.

- $\quad$ Stap 2: bepalen van een concept drempelwaarde voor schade (een definitie formuleren van de klimaatfactor; hoe droog moet het bijvoorbeeld zijn voordat er schade optreedt) en een inschatting van de impact als de klimaatfactor optreedt, in economische schade met een bandbreedte (lage en hoge schade). Belangrijk punt hier is dat het expertinschattingen betreft en geen harde proefresultaten. Daarbij hoort ook het selecteren van de kwetsbare periode. Dit bepaalt in welke maanden van het jaar het gewas kwetsbaar is voor het optreden van de klimaatfactor en er dus schade op zal treden.

- Stap 3: bespreken van de drempelwaarden van de klimaatfactoren per gewas en de bijbehorende schades met de gewasexperts ter verificatie en aanpassing.

- $\quad$ Stap 4: in deze stap worden de drempelwaarden doorgerekend op basis van weerdata afkomstig van KNMI-weerstation De Bilt. Hier is voor weerstation de Bilt gekozen, maar de frequenties kunnen ook voor andere weerstations in Nederland (zoals Eelde of Maastricht) berekend worden. Deze data bestaan uit de dag-gegevens van neerslag en temperatuur (gem., max., en min.) van de referentieperiode (1981-2010). Deze dag-gegevens zijn door het KNMI getransformeerd naar toekomstige klimaatscenario's. Dit is gedaan door de geprojecteerde verwachte veranderingen door klimaatmodellen toe te voegen aan de historische meetreeksen van de referentieperiode. Op basis van de gedefinieerde meteorologische definities uit de voorgaande stap kunnen zo de frequenties van klimaatfactoren worden bepaald. Zodra een drempelwaarde of een set van waardes wordt overschreden, zoals de hoeveelheid neerslag, een periode van hoge temperaturen of een combinatie hiervan, wordt 1 frequentie genoteerd. Door dit voor het klimaat te doen (30 jaar periode), kan bepaald worden hoe hoog de frequentie is in het referentieklimaat en in de klimaatscenario's voor de periode rond 2050. In dit onderzoek is gekozen om naast de referentieperiode de frequenties van weersextremen te bepalen voor de contrasterende klimaatscenario's $G_{L}$ en $W_{H}$ rond 2050 (2036-2065). De frequenties en de veranderingen daarvan in de klimaatscenario's ten opzichte van de referentieperiode, dient als input voor het berekenen van het financiële risico per gewas. In dit onderzoek zijn de frequenties opnieuw 
berekend vanuit de data van het KNMI. Daardoor kunnen de frequenties van gangbare gewassen wat verschillen van de frequenties die gepresenteerd zijn in Verstand et al. (2020) en Pondini (2017).

Stappen 1 tot en met 3 zijn uitgevoerd met Ruud Timmer, expert op het gebied van eiwitgewassen bij WUR - Open Teelten (pers. comm., 2020). Een gemiddelde grondsoort wordt als uitgangspunt genomen voor de ontwikkelen van de klimaatrisico's. In de praktijk kan de gevoeligheid voor weersextremen echter sterk afhangen en verschillen per bodem en teelt omstandigheden. Deze verschillen zijn deels in beeld gebracht door het gebruik van een schade band breedte (laag en hoog). Binnen de klimaatstresstest methodiek en dus ook dit project is het berekenen van de schade op specifieke grond soorten (nog) niet mogelijk en vraagt verder onderzoek.

Om het risico te berekenen, wordt de kans van optreden vermenigvuldigd met de impact. Uit bovenstaande vier stappen weten we de kans (frequentie per 30 jaar) en de impact op het gewas (met een lage en hoge inschatting). Met de verandering van de frequentie van huidig versus toekomstig klimaat kan berekend worden hoe het risico in de toekomst gaat veranderen. Dat wordt gedaan met indexen. De huidige bruto geldopbrengst van een gewas wordt onder huidig klimaat op 100 gesteld. Per klimaatfactor wordt er berekend hoe een klimaatscenario in $2050\left(G_{L}\right.$ en $\left.W_{H}\right)$ deze index beïnvloedt; een verlaging naar 90 in 2050 betekent dat er door deze specifieke klimaatfactor jaarlijks een reductie van $10 \%$ van de bruto geldopbrengst voorspeld wordt, als gevolg van een toename van de frequentie en dus een toename van het risico. Dit is dezelfde aanpak als in (Verstand, Schaap, Schoorlemmer, Wolf, et al., 2020). De bruto-geldopbrengsten van de gewassen zijn afkomstig uit de Kwantitatieve Informatie voor de Akkerbouw en de Vollegrondsgroenteteelt (KWIN AGV) (van der Voort, 2018). Voor de eiwitgewassen die niet in de KWIN AGV opgenomen zijn of waar de lokale condities sterk verschillen zijn expertinschattingen gebruikt. Voor de eiwitgewassen is gesproken met R. Timmer (pers. comm., 5 augustus 2020) en voor gewassen waarbij de lokale condities afwijken ten opzichte van de uitgangspunten van de KWIN AGV is gesproken met M. Van der Voort (pers. comm., 30 juni 2020).

Een voorbeeld van bovenstaande risicoberekening is hieronder gegeven voor het gewas pootaardappel, en daarin de klimaatfactor hittegolf (Verstand, Schaap, Schoorlemmer, Wolf, et al., 2020):

\section{Uitgangsgegevens}

- Pootaardappel

- bruto geldopbrengst $€ 10080$, KWIN 2018 Pootaardappel Noord NL eigen mechanisatie (van der Voort, 2018)

- Klimaatfactor: hittegolf (definitie: Minimaal 3 dagen $\geq 30^{\circ} \mathrm{C}$ in een periode van minimaal 5 dagen $\geq 25^{\circ} \mathrm{C}$ )

- Type impact: doorwas

- Periode van kwetsbaarheid: juli-september

- Weerstation: Eelde

\begin{tabular}{|c|c|c|c|}
\hline & Heden & Gematigd $G_{L}$ & Extreem $W_{H}$ \\
\hline Frequentie per 30 jaar & 11 & +7 & +26 \\
\hline
\end{tabular}

De frequenties van hittegolven gaan in de toekomst sterk toenemen. In de 30 jaar-periode rond 2050 (dus 2035 en 2065) gaan er dus 7 of 26 extra hittegolven plaatsvinden, in respectievelijk $G_{\llcorner} 2050$ en $W_{H}$ 2050. De kansen die gebruikt worden in de risicoberekening zijn dan $7 / 30=0.23$ in $G_{\llcorner} 2050$ en $26 / 30=0.867$ in $W_{H} 2050$.

Er zijn een aantal verbeteringen aangebracht in het Excel-werkblad waar de frequenties van klimaatfactoren berekend worden. Daardoor kunnen ten opzichte van Verstand et al. (2020) verschillen zijn ontstaan.

De impacts van deze klimaatfactor zijn als volgt:

\begin{tabular}{|c|c|c|}
\hline & Laag & Hoog \\
\hline Economische impact & $25 \%->€ 2520$ & $75 \%->€ 7560$ \\
\hline
\end{tabular}




\section{Risicoberekening}

Door de kans te vermenigvuldigen met de impact per event, krijgen we het risico in euro's per hectare per jaar. In dit geval voor hittegolven in pootaardappel is dat:

- Heden: Bruto geldopbrengst $=€ 10080$, waarin de huidige risico al ingebed is (index $=100$ ).

- 2050 G L 2050: risicotoename door een frequentietoename tussen $€ 580$ en $€ 1739$

- Lage impact: 0.23 (kans)*2520 (impact) $=€ 580$

- Hoge impact: $0.23 * 7560=€ 1739$

- $2050 \mathrm{~W}_{\mathrm{H}} 2050$ risico toename tussen $€ 2520$ en $€ 6555$

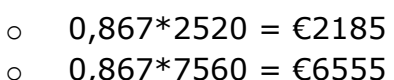

In de index (100), waar de huidige bruto geldopbrengst $€ 10080$ is:

- Huidige index (referentie) is 100

- Index in $G_{\llcorner}$2050:

○ Lage impact: $100-((580 / 10080) * 100)=94$

○ Hoge impact: $100-((1739 / 10080) * 100)=83$

- Index in $W_{H} 2050$ :

○ Lage impact: $100-((2185 / 10080) * 100)=78$

○ Hoge impact: $100-((6555 / 10080) * 100)=35$

Deze indexen zijn per klimaatfactor weergegeven en geven aan hoeveel van de oorspronkelijke opbrengst er jaarlijks overblijft als gevolg van de frequentieverandering door klimaatverandering. Als de ene index van een klimaatfactor een daling aangeeft (naar 80 bijvoorbeeld, het toegenomen risico is dan dus $100-80=20$ ), kan een andere stijgende index (naar bijvoorbeeld 120) dat compenseren. Twee dalende indexen kunnen niet gemiddeld worden, want iedere factor geeft voor enkel die factor aan hoeveel er nog van de bruto geldopbrengst in de toekomst overblijft.

\subsection{Resultaten}

In dit hoofdstuk worden de klimaatrisico's van de eiwitgewassen (3.3.1) en referentiegewassen gepresenteerd (3.3.2). Elk gewas bevat de relevante klimaatfactoren, de meteorologische definitie, de periode, het type impact en de economische impact bij optreden als percentage van de bruto geldopbrengst. Daarnaast worden van de verschillende klimaatfactoren de frequenties van de referentieperiode en klimaatscenario's $\left(G_{L}\right.$ en $W_{H}$ ) getoond. Tot slot worden risico's van de klimaatscenario's in de vorm van indexen gepresenteerd.

\subsubsection{Klimaatrisico's eiwitgewassen}

\subsubsection{Winterveldboon}

Het zaaien van de winterveldboon gebeurt gewoonlijk in oktober. Door vroeger te zaaien wordt de kans op watertekort en insectenplagen beperkt (Lecat, 2005). De oogst vindt plaats in augustus. Winterveldbonen kunnen 1 op de 5 jaar geteeld worden (teelttechnisch; bodemgezondheid) in een rotatie met standaard akkerbouwgewassen. De geformuleerde klimaatfactoren voor de winterveldboon zijn in Tabel $\mathbf{3 . 2}$ weergegeven. Hieruit blijkt dat wanneer het lang nat is tijdens de groeiperiode, dit kan resulteren in plantwegval en hierdoor opbrengstverlies. Opbrengstverlies kan ook optreden bij een periode van stevige vorst. Overige klimaatfactoren die een rol spelen bij de teelt van winterveldbonen worden bij de zomerveldbonen uitgewerkt. 
Tabel 3.2 Klimaatfactoren, meteorologische definitie, periode, type impact en economische impact (\%) voor Winterveldboon (Timmer, pers. comm.).

\begin{tabular}{|c|c|c|c|c|}
\hline Klimaatfactor & Meteorologische definitie & Periode & Impact & Schade \\
\hline Lang nat & $\begin{array}{l}\text { Minimaal } 75 \% \text { van de } 14 \text { dagen met } \\
\text { een dagelijkse neerslag } \geq 2 \mathrm{~mm}\end{array}$ & Dec-Apr & $\begin{array}{l}\text { Plantwegval en hierdoor } \\
\text { opbrengstverlies }\end{array}$ & $10 \%-50 \%$ \\
\hline Vorst & $\begin{array}{l}\text { Minimaal } 3 \text { dagen met een } \\
\text { minimumtemperatuur } \leq-5^{\circ} \mathrm{C}\end{array}$ & Nov-Mrt & $\begin{array}{l}\text { Plantwegval en hierdoor } \\
\text { opbrengstverlies }\end{array}$ & $5 \%-15 \%$ \\
\hline Strenge vorst & $\begin{array}{l}\text { Minimaal } 1 \text { dag met een } \\
\text { minimumtemperatuur } \leq-15^{\circ} \mathrm{C}\end{array}$ & Nov-Mrt & $\begin{array}{l}\text { Plantwegval en hierdoor } \\
\text { opbrengstverlies }\end{array}$ & $90 \%-100 \%$ \\
\hline
\end{tabular}

In Tabel 3.3 zijn de frequenties van de hiervoor voorgenoemde klimaatfactoren weergeven. De klimaatfactor 'lang nat' blijft onder het $\mathrm{G}_{\mathrm{L}}$-scenario gelijk, maar laat onder het $\mathrm{W}_{\mathrm{H}}$-scenario een stijging zien. Een periode van vorst laat daarentegen in beide scenario's een sterke daling zien ten opzichte van de referentieperiode.

Tabel 3.3 Frequenties referentieperiode en klimaatscenario's van weersextremen per klimaatfactor voor Winterveldboon.

\begin{tabular}{|c|c|c|c|c|c|}
\hline Klimaatfactor & Ref. periode & $G_{L} 2050$ & $W_{H} 2050$ & $\Delta \mathrm{G}_{\mathrm{L}} 2050^{1}$ & $\Delta W_{H} 2050^{1}$ \\
\hline Lang nat & 12 & 12 & 16 & 0 & 4 \\
\hline Vorst & 46 & 24 & 3 & -22 & -30 \\
\hline
\end{tabular}

${ }^{1}$ Verwachte verandering $(\Delta)$ van de frequenties onder de KNMI-klimaatscenario's (GL 2050 en WH 2050) t.o.v. de referentieperiode 1981-2010.

De indexen van de klimaatfactoren zijn inzichtelijk gemaakt in Tabel 3.4; een daling of stijging van de indexen van de individuele klimaatfactoren hangt samen met een daling of stijging van de hiervoor beschreven frequenties uit Tabel 3.3. Hieruit komt naar voren dat door de wijzigingen in frequenties de opbrengst bij 'lang nat' onder $\mathrm{W}_{\mathrm{H}}$-scenario lager uitvalt. Voor de klimaatfactor 'vorst' zal de opbrengst naar verwachting stijgen in vergelijking tot de referentieperiode.

Tabel 3.4 Geïndexeerde effecten risico's klimaatfactoren voor klimaatscenario's en impact (laag en hoog) ten opzichte van referentieperiode per klimaatfactor voor Winterveldboon.

\begin{tabular}{|c|c|c|c|c|c|}
\hline Klimaatfactor & Ref. periode & G 2050 laag & $\mathrm{G}_{\mathrm{L}} 2050$ hoog & $W_{\text {H }} 2050$ laag & $W_{H} 2050$ hoog \\
\hline Lang nat & 100 & 100 & 100 & 99 & 93 \\
\hline Vorst & 100 & 104 & 111 & 105 & 115 \\
\hline
\end{tabular}

\subsubsection{Zomerveldboon}

Het zaaien van de zomerveldboon gebeurt in maart of april, de oogst vindt plaats rond begin september. Zomerveldbonen kunnen teelttechnisch 1 op 5 jaar worden geteeld (uit oogpunt van bodemgezondheid) in een rotatie met standaard akkerbouwgewassen. De klimaatfactoren in Tabel 3.5 laten zien dat weersextremen zich met name voordoen in het midden en het eind van het groeiseizoen. Net als de winterveldboon moeten zomerveldbonen zo vroeg mogelijk gezaaid worden om het risico op watertekort en insectenplagen te beperken. Ideale condities voor bladluizen zijn namelijk een warme en droge periode in mei en juni. In juni kunnen door een natte periode bladvlekkenziektes (zoals de Botrytis-soorten) ontstaan in stengels, peulen en blad wat zorgt voor een verminderde peulvulling. In juli en augustus kunnen warme en droge periodes voor een lagere fysieke opbrengst zorgen. Een natte periode in deze maanden kan de bladeren van de veldboon aantasten waardoor de fysieke opbrengst lager uitvalt. Hevige regenval in juli-september kan voor legering zorgen bij het gewas. 
Tabel 3.5 Klimaatfactoren, meteorologische definitie, periode, type impact en economische impact (\%) voor winter- en zomerveldbonen (Timmer, pers. comm.).



In Tabel 3.6 zijn de frequenties van de klimaatfactoren uit Tabel 3.5 weergegeven. Hieruit komt naar voren, dat hittegolf en hevige regenval onder de referentieperiode en de klimaatscenario's het vaakst voorkomen. Onder het GL-scenario nemen de klimaatfactoren 'droge periode' en 'nat tijdens bloeiperiode' af, daarentegen stijgen de frequenties van de hittegolf en hevige regenval. Voor het $\mathrm{W}_{\mathrm{H}^{-}}$ scenario zijn de veranderingen groter. Zo laten 'hittegolf' en 'droge periode' sterke stijgingen zien. De frequenties van de klimaatfactoren 'nat tijdens bloeiperiode' en 'nat tijdens korrelvullingsperiode' dalen.

Tabel 3.6 Frequenties referentieperiode en klimaatscenario's van weersextremen per klimaatfactor voor winter- en zomerveldbonen.

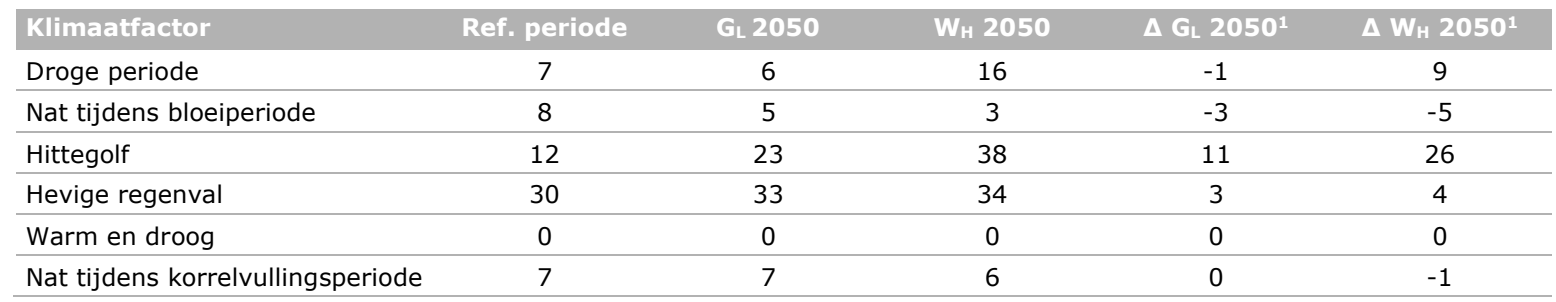

${ }^{1}$ Verwachte verandering $(\Delta)$ van de frequenties onder de KNMI-klimaatscenario's (GL 2050 en WH 2050) t.o.v. de referentieperiode 1981-2010.

De indexen van de klimaatfactoren zijn inzichtelijk gemaakt in Tabel 3.7; een daling of stijging van de indexen van de individuele klimaatfactoren hangt samen met een daling of stijging van de hiervoor beschreven frequenties uit Tabel 3.6. Hieruit komt naar voren dat in het $\mathrm{W}_{\mathrm{H}}$-scenario de indexen van droge periode dalen, met name bij hoge impact. Voor de klimaatfactor 'hittegolf' vallen de indexen lager uit voor het GL-scenario (hoog) en $\mathrm{W}_{\mathrm{H}}$-scenario (hoog).

Tabel 3.7 Geïndexeerde effecten van risico's voor klimaatscenario's en impact (laag en hoog) ten opzichte van referentieperiode per klimaatfactor voor winter- en zomerveldbonen.

\begin{tabular}{|c|c|c|c|c|c|}
\hline Klimaatfactor & Ref. periode & $G_{L} 2050$ laag & $\mathrm{G}_{\mathrm{L}} 2050 \mathrm{hoog}$ & $W_{H} 2050$ laag & $W_{H} 2050$ hoog \\
\hline Droge periode & 100 & 100 & 102 & 97 & 85 \\
\hline Nat tijdens bloeiperiode & 100 & 101 & 103 & 102 & 105 \\
\hline Hevige regenval & 100 & 100 & 99 & 100 & 99 \\
\hline Warm en droog & 100 & 100 & 100 & 100 & 100 \\
\hline
\end{tabular}




\subsubsection{Droge erwten}

Het zaaien van droge erwten vindt plaats in maart en april en het oogsttijdstip bevindt zich tussen eind juli en begin augustus. Droge erwten kunnen teelttechnisch 1 op 5 worden geteeld (uit oogpunt van bodemgezondheid) in een rotatie met standaard akkerbouwgewassen. De klimaatfactoren in Tabel 3.8 laten zien dat weersextremen zich met name voordoen in het midden en het eind van het groeiseizoen. In mei kan het gewas tijdens een warme en droge periode worden aangetast door bladluizen, maar de impact hiervan is gering. Deze droogte speelt ook een rol in juni en juli met groeireductie tot gevolg, wat resulteert in een lagere fysieke opbrengst. Natheid daarentegen kan ook voor problemen zorgen. In juni kunnen door een natte periode bladvlekkenziektes (zoals de Botrytissoorten) ontstaan in stengels, peulen en blad, wat zorgt voor een verminderde peulvulling. In juli kan er tijdens zware neerslag en wind legering optreden. Hierdoor hebben eenden en duiven de kans om verdere schade aan te richten. Wanneer het tegen de oogstperiode in juli en augustus te lang nat is, kunnen Ascochyta-schimmels vlekken veroorzaken op stengels, peulen en blad. Daarnaast kan deze natte periode ervoor zorgen dat oogstwerkzaamheden moeten worden uitgesteld, waardoor overrijpe peulen kunnen openspringen en forse verliezen op kunnen treden.

Tabel 3.8 Klimaatfactoren, meteorologische definitie, periode, type impact en economische impact (\%) voor droge erwten (Timmer, pers. comm.).

\begin{tabular}{|c|c|c|c|c|}
\hline Klimaatfactor & Meteorologische definitie & Periode & Type impact & Impact \\
\hline $\begin{array}{l}\text { Nat tijdens } \\
\text { bloeiperiode }\end{array}$ & $\begin{array}{l}\text { Minimaal } 75 \% \text { van } 14 \text { dagen met } \\
\text { een dagelijkse neerslag } \geq 0,5 \mathrm{~mm}\end{array}$ & Jun & $\begin{array}{l}\text { Ontstaan bladvlekkenziekten (zoals } \\
\text { Botrytis-soorten) in stengels, peulen } \\
\text { en blad, wat resulteert in minder } \\
\text { peulvulling en lagere kwaliteit. }\end{array}$ & $10 \%-40 \%$ \\
\hline $\begin{array}{l}\text { Nat tijdens } \\
\text { korrelvullingsperiode }\end{array}$ & $\begin{array}{l}\text { Minimaal } 1 \text { dag met neerslag } \geq 25 \\
\mathrm{~mm}\end{array}$ & Jul & $\begin{array}{l}\text { De planten zakken in elkaar } \\
\text { (legering), waardoor eenden, duiven } \\
\text { en onkruid de kans krijgen om } \\
\text { schade aan te richten. }\end{array}$ & $10 \%-50 \%$ \\
\hline Droogte & $\begin{array}{l}\text { Droge periode van minimaal } 21 \\
\text { dagen met een neerslag } \leq 5 \mathrm{~mm}\end{array}$ & Jun-Jul & $\begin{array}{l}\text { Lagere fysieke opbrengst door } \\
\text { gereduceerde groei. }\end{array}$ & $10 \%-30 \%$ \\
\hline Warm en droog & $\begin{array}{l}\text { Droge periode van minimaal } 21 \\
\text { dagen met een neerslag } \leq 5 \mathrm{~mm} \text { en } \\
\text { minimaal } 14 \text { opeenvolgende dagen } \\
\text { met een maximumtemperatuur } \geq \\
20 \mathrm{C}\end{array}$ & Mei-Jun & Virusaantasting door bladluizen. & $\begin{array}{l}\text { Geen grote } \\
\text { impact }\end{array}$ \\
\hline
\end{tabular}

In Tabel 3.9 zijn de frequenties van de klimaatfactoren uit Tabel 3.8 weergegeven. Hieruit komt naar voren dat 'nat tijdens korrelvullingsperiode' onder de referentieperiode het vaakst voorkomt. Onder het GL-scenario blijft dit het meest voorkomende weersextreem. Voor het $W_{H}$-scenario neemt met name droogte sterk toe. 'Nat tijdens bloeiperiode' neemt daarentegen onder het $\mathrm{G}_{\mathrm{L}}$ - en $\mathrm{W}_{\mathrm{H}^{-}}$ scenario af.

Tabel 3.9 Frequenties referentieperiode en klimaatscenario's van weersextremen per klimaatfactor voor droge erwten.

\begin{tabular}{|c|c|c|c|c|c|}
\hline Klimaatfactor & Ref. periode & GL 2050 & $W_{H} 2050$ & $\Delta G_{L} 2050^{1}$ & $\Delta W_{H} 2050^{1}$ \\
\hline Nat tijdens bloeiperiode & 8 & 5 & 3 & -3 & -5 \\
\hline Nat tijdens korrelvullingsperiode & 13 & 13 & 13 & 0 & 0 \\
\hline Warm en droog & 0 & 0 & 0 & 0 & 0 \\
\hline Nat tijdens korrelvullingsperiode & 18 & 17 & 11 & -1 & -7 \\
\hline
\end{tabular}

${ }^{1}$ Verwachte verandering $(\Delta)$ van de frequenties onder de KNMI-klimaatscenario's (GL 2050 en WH 2050) t.o.v. de referentieperiode 1981-2010. 
De indexen van de klimaatfactoren zijn inzichtelijk gemaakt in Tabel 3.10; een daling of stijging van de indexen van de individuele klimaatfactoren hangt samen met een daling of stijging van de hiervoor beschreven frequenties uit Tabel 3.9. Hieruit komt naar voren dat de verschillen in het $\mathrm{G}_{\mathrm{L}}$-scenario ten opzichte van de referentieperiode relatief klein zijn. Voor het $\mathrm{W}_{\mathrm{H}}$-scenario zijn de verschillen groter. Zo dalen de indexen bij de klimaatfactor droogte, maar laten ze een stijging zien voor 'nat tijdens korrelvullingsperiode'.

Tabel 3.10 Geïndexeerde effecten van risico's voor klimaatscenario's en impact (laag en hoog) ten opzichte van referentieperiode per klimaatfactor voor droge erwten.

\begin{tabular}{|c|c|c|c|c|c|}
\hline Klimaatfactor & Ref. periode & $\mathrm{G}_{\mathrm{L}} 2050$ laag & $\mathrm{G}_{\mathrm{L}} 2050$ hoog & $W_{H} 2050$ laag & $W_{H} 2050$ hoog \\
\hline Nat tijdens bloeiperiode & 100 & 101 & 104 & 102 & 107 \\
\hline Nat tijdens korrelvullingsperiode & 100 & 100 & 100 & 100 & 100 \\
\hline Warm en droog & 100 & 100 & 100 & 100 & 100 \\
\hline Nat tijdens korrelvullingsperiode & 100 & 100 & 101 & 102 & 109 \\
\hline
\end{tabular}

\subsubsection{Bruine bonen}

Het zaaien van bruine bonen vindt omstreeks half mei plaats en de oogst in september. Bruine bonen kunnen teelttechnisch 1 op 5 worden geteeld (uit oogpunt van bodemgezondheid) in een rotatie met standaard akkerbouwgewassen. De klimaatfactoren in Tabel $\mathbf{3 . 1 1}$ laten zien dat weersextremen zich door het gehele seizoen voordoen. In het begin van het groeiseizoen kan nachtvorst voor grote schade zorgen door het kapotvriezen van planten. In mei kan ook door te lage gemiddelde temperaturen de opkomstperiode worden vertraagd. Hierdoor zijn de bonen extra kwetsbaar voor vraat door duiven. Wanneer er in mei en juni teveel neerslag valt, kan het gewas door zuurstofgebrek afsterven. In juni kunnen door een natte periode bladvlekkenziektes (zoals de Botrytis-soorten) ontstaan in stengels, peulen en blad wat zorgt voor een verminderde peulvulling. Droogte in juli en augustus kan ertoe leiden dat de peul- en zaadvorming wordt geremd, wat leidt tot een lagere opbrengst. Wanneer er tijdens de afrijpfase te natte omstandigheden optreden, kunnen schimmels het blad infecteren wat leidt tot kwaliteitsverlies. Ook kunnen deze natte omstandigheden ertoe leiden dat de oogst moet worden uitgesteld, waardoor de bonen openspringen omdat ze overrijp zijn, wat kan leiden tot opbrengstverlies.

Tabel 3.11 Klimaatfactoren, meteorologische definitie, periode, impact en schade voor bruine bonen (Timmer, pers. comm.).

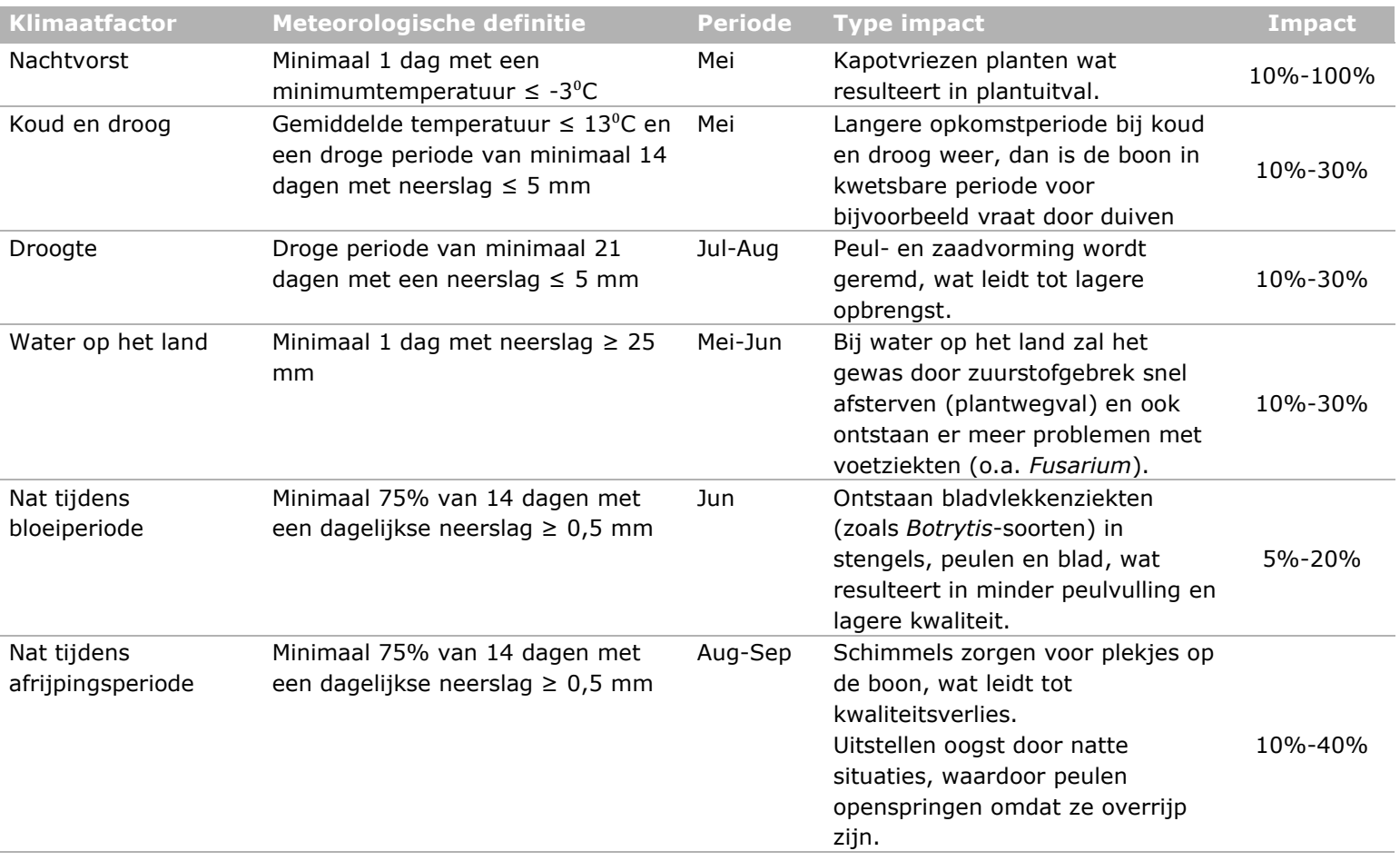


In Tabel 3.12 zijn de frequenties van de klimaatfactoren uit Tabel 3.11 weergegeven. Hieruit komt naar voren dat klimaatfactoren 'droogte' en 'water op het land' onder de referentieperiode en de klimaatscenario's het vaakst voorkomen. In het GL-scenario neemt 'water op het land' toe en nemen 'nat tijdens bloeiperiode' en droogte af. In het $\mathrm{W}_{\mathrm{H}}$-scenario is een sterke stijging te zien voor 'droogte' en 'water op het land'. 'Nat tijdens bloeiperiode' en 'nat tijdens afrijpingsfase' dalen onder dit scenario juist sterk.

Tabel 3.12 Frequenties referentieperiode en klimaatscenario's van weersextremen per klimaatfactor voor bruine bonen.

\begin{tabular}{|c|c|c|c|c|c|}
\hline Klimaatfactor & Ref. periode & $\mathrm{G}_{L} \mathbf{2 0 5 0}$ & $W_{H} 2050$ & $\Delta \mathrm{G}_{\mathrm{L}} 2050^{1}$ & $\Delta W_{H} 2050^{1}$ \\
\hline Nachtvorst & 0 & 0 & 0 & 0 & 0 \\
\hline Koud en droog & 1 & 1 & 1 & 0 & 0 \\
\hline Water op het land & 9 & 12 & 14 & 3 & 5 \\
\hline Nat tijdens bloeiperiode & 8 & 5 & 3 & -3 & -5 \\
\hline
\end{tabular}

${ }^{1}$ Verwachte verandering $(\Delta)$ van de frequenties onder de KNMI-klimaatscenario's (GL 2050 en WH 2050) t.o.v. de referentieperiode 1981-2010.

De indexen van de klimaatfactoren zijn inzichtelijk gemaakt in Tabel 3.13; een daling of stijging van de indexen van de individuele klimaatfactoren hangt samen met een daling of stijging van de hiervoor beschreven frequenties uit Tabel 3.12. Hieruit komt naar voren dat de indexen van klimaatfactor 'water op het land' dalen in het $\mathrm{G}_{\mathrm{L}}$ - en $\mathrm{W}_{\mathrm{H}}$-scenario. In het laatstgenoemde scenario dalen de index ook relatief sterk voor droogte. Aan de andere kant stijgen in het $\mathrm{W}_{\mathrm{H}}$-scenario de indexen voor 'nat tijdens afrijpingsperiode'.

Tabel 3.13 Geïndexeerde effecten van risico's voor klimaatscenario's en impact (laag en hoog) ten opzichte van referentieperiode per klimaatfactor voor bruine bonen.

\begin{tabular}{|c|c|c|c|c|c|}
\hline Klimaatfactor & Ref. periode & $\mathrm{G}_{\mathrm{L}} 2050$ laag & $\mathrm{G}_{\mathrm{L}} 2050$ hoog & $W_{\text {H }} 2050$ laag & $W_{\text {H }} 2050$ hoog \\
\hline Nachtvorst & 100 & 100 & 100 & 100 & 100 \\
\hline Koud en droog & 100 & 100 & 100 & 100 & 100 \\
\hline Droogte & 100 & 100 & 101 & 97 & 91 \\
\hline Water op het land & 100 & 99 & 97 & 98 & 95 \\
\hline Nat tijdens bloeiperiode & 100 & 101 & 102 & 101 & 103 \\
\hline Nat tijdens afrijpingsperiode & 100 & 100 & 100 & 102 & 109 \\
\hline
\end{tabular}

\subsubsection{Soja}

Het zaaien van soja vindt plaats in april of mei met de oogst in het begin van september. Soja kan teelttechnisch 1:5 worden geteeld (uit oogpunt van bodemgezondheid) in een rotatie met standaardakkerbouwgewassen. Soja is een vorstgevoelig gewas, waardoor het niet te vroeg gezaaid kan worden. De klimaatfactoren in Tabel 3.14 laten zien dat weersextremen zich door het gehele seizoen voor doen. Wanneer er na het zaaien vorst optreedt, kan dit tot grote schade leiden door het kapotvriezen van kiemplanten. In de periode juni - augustus kan bij een lange periode van natheid de bodemziekte Sclerotinia optreden. Hierdoor kunnen er geen nutriënten meer opgenomen worden, waardoor de plant verwelkt. Wanneer er in de zomer een hittegolf optreedt, kan dit leiden tot een lagere fysieke opbrengst door een gereduceerde groei en een versnelde afrijping. Bij een langere periode van natheid in september en oktober kunnen er schimmelvlekjes op de zaden ontstaan. Bij nog meer neerslag in deze periode kan het voorkomen dat er niet kan worden geoogst met de combine. 
Tabel 3.14 Klimaatfactoren, meteorologische definitie, periode, type impact en economische impact (\%) voor soja (Timmer, pers. comm.).

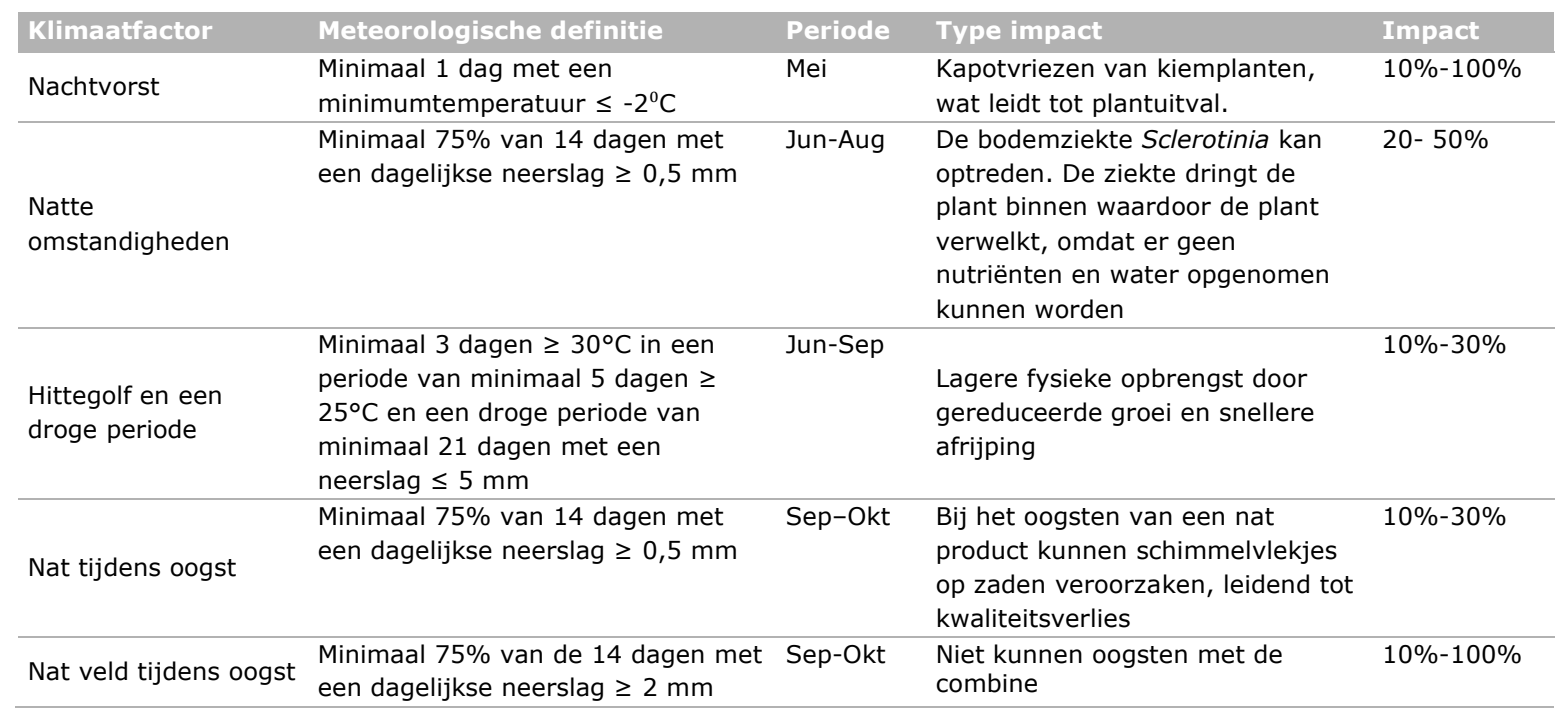

In Tabel 3.15 zijn de frequenties van de klimaatfactoren uit Tabel 3.14 weergegeven. Hieruit komt naar voren dat natte omstandigheden en nat tijdens oogst onder de referentieperiode en de klimaatscenario's het vaakst voorkomen. Onder het GL-scenario nemen de frequenties van hittegolf en een droge periode en nat veld tijdens oogst toe, daarentegen dalen de frequenties van nachtvorst en natte omstandigheden. Onder het $\mathrm{W}_{\mathrm{H}}$-scenario zijn de veranderingen groter, zo stijgt hittegolf en een droge periode verder door, tegelijkertijd dalen wederom de frequenties van nachtvorst en 'natte omstandigheden', 'nat tijdens oogst' en 'nat veld tijdens oogst'.

Tabel 3.15 Frequenties referentieperiode en klimaatscenario's van weersextremen per klimaatfactor voor soja.

\begin{tabular}{|c|c|c|c|c|c|}
\hline Klimaatfactor & Ref. periode & $\mathrm{G}_{L} 2050$ & $W_{H} 2050$ & $\Delta \mathrm{G}_{\mathrm{L}} 2050^{1}$ & $\triangle W_{H} 2050^{1}$ \\
\hline Nachtvorst & 2 & 0 & 0 & -2 & -2 \\
\hline Natte omstandigheden & 26 & 22 & 14 & -4 & -12 \\
\hline Nat tijdens oogst & 18 & 18 & 14 & 0 & -4 \\
\hline Nat veld tijdens oogst & 7 & 9 & 6 & 2 & -1 \\
\hline
\end{tabular}

${ }^{1}$ Verwachte verandering $(\Delta)$ van de frequenties onder de KNMI-klimaatscenario's (GL 2050 en WH 2050) t.o.v. de referentieperiode 1981-2010.

De indexen van de klimaatfactoren zijn inzichtelijk gemaakt in Tabel 3.16; een daling of stijging van de indexen van de individuele klimaatfactoren hangt samen met een daling of stijging van de hiervoor beschreven frequenties uit Tabel 3.15. Hieruit komt naar voren dat de meeste indexen in de klimaatscenario's wijzigen: de grootse veranderingen zijn te zien in het $\mathrm{G}_{\mathrm{L}}$ (hoog) en het $\mathrm{W}_{\mathrm{H}^{-}}$-scenario (laag en hoog). In deze scenario's neemt de index van de klimaatfactor 'natte omstandigheden' sterk toe. Daarnaast dalen de indexen onder de klimaatfactor 'hittegolf en een droge periode'.

Tabel 3.16 Geïndexeerde effecten van risico's voor klimaatscenario's en impact (laag en hoog) ten opzichte van referentieperiode per klimaatfactor voor soja.

\begin{tabular}{|c|c|c|c|c|c|}
\hline Klimaatfactor & Ref. periode & G. 2050 laag & GL 2050 hoog & $W_{\text {H }} 2050$ laag & $\mathrm{W}_{\text {H }} 2050$ hoog \\
\hline Nachtvorst & 100 & 101 & 107 & 101 & 107 \\
\hline Natte omstandigheden & 100 & 103 & 107 & 108 & 120 \\
\hline Nat tijdens oogst & 100 & 100 & 100 & 101 & 104 \\
\hline Nat veld tijdens oogst & 100 & 99 & 93 & 100 & 103 \\
\hline
\end{tabular}




\subsubsection{Klimaatrisico's referentie gewassen}

Om de klimaatrisico's van eiwitgewassen te kunnen vergelijken met veelvoorkomende akkerbouwgewassen, worden in deze paragraaf per gewas de frequenties van de referentieperiode en klimaatscenario's en daarvan afgeleide berekende indexen weergegeven. Dit is gedaan voor de volgende gewassen: poot- en consumptieaardappelen, wintertarwe, suikerbieten, zaaiuien, winterwortel, snijmaïs en gras. Voor een beschrijving van de klimaatfactoren, kwetsbare perioden en impacts van deze gewassen, zie (Pondini, 2017; Verstand, Schaap, Schoorlemmer, Wolf, et al., 2020; Wit de et al., 2009). In Bijlage 2 staan de codes van de klimaatfactor inclusief meteorologische definities uitgeschreven.

\subsubsection{Poot- en consumptieaardappelen}

In Tabel 3.17 zijn de frequenties van de klimaatfactoren weergegeven voor poot- en consumptieaardappelen.

Tabel 3.17 Frequenties referentieperiode en klimaatscenario's van weersextremen per klimaatfactor voor poot- en consumptieaardappelen.

\begin{tabular}{|c|c|c|c|c|c|}
\hline Klimaatfactor & Ref. periode & GL 2050 & $W_{H} 2050$ & $\Delta G_{L} 2050^{1}$ & $\Delta W_{H} 2050^{1}$ \\
\hline Natte periode WP-3 & 41 & 43 & 56 & 2 & 15 \\
\hline Hevige neerslag WP-5 & 8 & 11 & 14 & 3 & 6 \\
\hline Warm en nat W-WP-2 & 5 & 16 & 23 & 11 & 18 \\
\hline Natte periode WP-3 & 18 & 15 & 12 & -3 & -6 \\
\hline
\end{tabular}

${ }^{1}$ Verwachte verandering $(\Delta)$ van de frequenties onder de KNMI-klimaatscenario's (GL 2050 en WH 2050) t.o.v. de referentieperiode 1981-2010.

De indexen van de klimaatfactoren zijn gepresenteerd in Tabel 3.20. Voor het GL-scenario dalen met name de indexen van de klimaatfactoren hittegolf, 'warm en nat' en 'warme winter'. Daarentegen stijgt de opbrengst voor 'natte periode'. Onder het $\mathrm{W}_{\mathrm{H}}$-scenario spelen de hiervoor genoemde indexen eveneens een rol, waarbij ze wel de geobserveerde stijging of daling versterken.

Tabel 3.18 Geïndexeerde effecten van risico's voor klimaatscenario's ten opzichte van referentieperiode per klimaatfactor voor poot- en consumptieaardappelen.

\begin{tabular}{|c|c|c|c|c|c|}
\hline Klimaatfactor & Ref. periode & $G_{L} 2050$ laag & $\mathrm{G}_{\mathrm{L}} 2050$ hoog & $W_{\text {H }} 2050$ laag & $W_{H} 2050$ hoog \\
\hline Natte periode WP-3 & 100 & 100 & 100 & 100 & 100 \\
\hline Hevige neerslag WP-5 & 100 & 98 & 93 & 95 & 85 \\
\hline Warm en nat W-WP-2 & 100 & 96 & 82 & 94 & 70 \\
\hline Natte periode WP-3 & 100 & 105 & 110 & 110 & 120 \\
\hline
\end{tabular}




\subsubsection{Wintertarwe}

In Tabel 3.19 zijn de frequenties van de klimaatfactoren weergegeven voor wintertarwe.

Tabel 3.19 Frequenties referentieperiode en klimaatscenario's van weersextremen per klimaatfactor voor wintertarwe.

\begin{tabular}{|c|c|c|c|c|c|}
\hline Klimaatfactor & Ref. periode & $\mathrm{G}_{L} 2050$ & $W_{H} 2050$ & $\Delta \mathrm{G}_{\mathrm{L}} \mathbf{2 0 5 0 ^ { 1 }}$ & $\Delta W_{H} 2050^{1}$ \\
\hline Natte periode WP-3 & 20 & 21 & 28 & 1 & 8 \\
\hline Vriezen en dooien F-5 & 3 & 1 & 1 & -2 & -2 \\
\hline Natte periode WP-3 & 6 & 8 & 5 & 2 & -1 \\
\hline Natte periode WP-3 & 13 & 12 & 8 & -1 & -5 \\
\hline
\end{tabular}

${ }^{1}$ Verwachte verandering $(\Delta)$ van de frequenties onder de KNMI-klimaatscenario's (GL 2050 en WH 2050) t.o.v. de referentieperiode 1981-2010.

De indexen van de klimaatfactoren zijn gepresenteerd in Tabel 3.20. Voor het GL-scenario daalt de index van de klimaatfactor 'natte periode' en stijgen de indexen van 'vriezen en dooien' en 'natte periode'. Onder het $W_{H}$-scenario daalt de index voor droge perioden, maar stijgen de indexen van 'vriezen en dooien' en 'natte periode'.

Tabel 3.20 Geïndexeerde effecten van risico's voor klimaatscenario's ten opzichte van referentieperiode per klimaatfactor voor wintertarwe.

\begin{tabular}{|c|c|c|c|c|c|}
\hline Klimaatfactor & Ref. periode & GL 2050 laag & GL 2050 hoog & WH 2050 laag & $\mathrm{W}_{\mathrm{H}} 2050 \mathrm{hoog}$ \\
\hline Natte periode WP-3 & 100 & 100 & 100 & 100 & 100 \\
\hline Vriezen en dooien F-5 & 100 & 101 & 103 & 101 & 103 \\
\hline Natte periode WP-3 & 100 & 98 & 95 & 101 & 103 \\
\hline Natte periode WP-3 & 100 & 101 & 103 & 104 & 113 \\
\hline Natte periode WP-3 & 100 & 100 & 103 & 101 & 108 \\
\hline
\end{tabular}

\subsubsection{Suikerbieten}

In Tabel 3.21 zijn de frequenties van de klimaatfactoren weergegeven voor suikerbieten.

Tabel 3.21 Frequenties referentieperiode en klimaatscenario's van weersextremen per klimaatfactor voor suikerbieten.

\begin{tabular}{|c|c|c|c|c|c|}
\hline Klimaatfactor & Ref. periode & $\mathrm{G}_{L} 2050$ & $W_{H} 2050$ & $\Delta \mathrm{G}_{\mathrm{L}} 2050^{1}$ & $\Delta W_{H} 2050^{1}$ \\
\hline Droge periode $\mathrm{D}-2$ & 3 & 3 & 2 & 0 & -1 \\
\hline Natte periode WP-7 & 27 & 28 & 27 & 1 & 0 \\
\hline Warme winter W-2 & 4 & 11 & 31 & 7 & 27 \\
\hline Nachtvorst F-1 & 47 & 12 & 1 & -35 & -46 \\
\hline
\end{tabular}

${ }^{1}$ Verwachte verandering $(\Delta)$ van de frequenties onder de KNMI-klimaatscenario's (GL 2050 en WH 2050) t.o.v. de referentieperiode 1981-2010.

De indexen van de klimaatfactoren zijn gepresenteerd in Tabel 3.22. Voor het GL-scenario daalt de index van 'warme winter', maar stijgen de indexen van 'natte periode (WP-2)' en nachtvorst. In het $W_{H}$-scenario daalt de index van warme winter verder, daarentegen nemen indexen van 'natte periode (WP-2)' en nachtvorst sterk toe. 
Tabel 3.22 Geïndexeerde effecten van risico's voor klimaatscenario's ten opzichte van referentieperiode per klimaatfactor voor suikerbieten.

\begin{tabular}{|c|c|c|c|c|c|}
\hline Klimaatfactor & Ref. periode & $\mathrm{G}_{\mathrm{L}} 2050$ laag & $\mathrm{G}_{\mathrm{L}} 2050$ hoog & $W_{\text {H }} 2050$ laag & $W_{H} 2050$ hoog \\
\hline Droge periode $\mathrm{D}-2$ & 100 & 100 & 100 & 101 & 101 \\
\hline Natte periode WP-7 & 100 & 100 & 99 & 100 & 100 \\
\hline Warme winter W-2 & 100 & 98 & 94 & 91 & 78 \\
\hline Nachtvorst F-1 & 100 & 112 & 123 & 115 & 131 \\
\hline
\end{tabular}

\subsubsection{Zaaiuien}

In Tabel 3.23 zijn de frequenties van de klimaatfactoren weergegeven voor zaaiuien.

Tabel 3.23 Frequenties referentieperiode en klimaatscenario's van weersextremen per klimaatfactor voor zaaiuien.

\begin{tabular}{|c|c|c|c|c|c|}
\hline Klimaatfactor & Ref. periode & $G_{L} 2050$ & $W_{H} 2050$ & $\Delta \mathrm{G}_{\mathrm{L}} 2050^{1}$ & $\Delta W_{H} 2050^{1}$ \\
\hline Droge periode D-2 & 5 & 5 & 4 & 0 & -1 \\
\hline Droge periode $\mathrm{D}-3$ & 5 & 5 & 11 & 0 & 6 \\
\hline Hevige neerslag WP-10 & 1 & 2 & 4 & 1 & 3 \\
\hline Warm en nat W-WP-2 & 5 & 16 & 27 & 11 & 22 \\
\hline
\end{tabular}

${ }^{1}$ Verwachte verandering $(\Delta)$ van de frequenties onder de KNMI-klimaatscenario's (GL 2050 en WH 2050) t.o.v. de referentieperiode $1981-2010$.

De indexen van de klimaatfactoren zijn gepresenteerd in Tabel 3.24. Voor het GL-scenario daalt met name de klimaatfactor 'warm en nat'. Verder blijkt dat in dit scenario geen stijgingen van de indexen worden verwacht. In het $\mathrm{W}_{\mathrm{H}}$-scenario zijn de dalingen sterker, zo daalt wederom 'warm en nat' het sterkst. Daarnaast dalen de indexen van 'droge periode (D-3)' en 'hevige neerslag'. Wederom zijn de stijgingen beperkt en laat alleen 'droge periode (D-2)' een hogere index zien.

Tabel 3.24 Geïndexeerde effecten van risico's voor klimaatscenario's ten opzichte van referentieperiode per klimaatfactor voor zaaiuien.

\begin{tabular}{|c|c|c|c|c|c|}
\hline Klimaatfactor & Ref. periode & G. 2050 laag & GL 2050 hoog & Wн 2050 laag & $W_{\text {H }} 2050$ hoog \\
\hline Droge periode D-2 & 100 & 100 & 100 & 100 & 103 \\
\hline Droge periode $\mathrm{D}-3$ & 100 & 100 & 100 & 94 & 92 \\
\hline Hevige neerslag WP-10 & 100 & 100 & 98 & 99 & 95 \\
\hline Warm en nat W-WP-2 & 100 & 82 & 78 & 63 & 56 \\
\hline
\end{tabular}

\subsubsection{Winterwortel}

In Tabel 3.25 zijn de frequenties van de klimaatfactoren weergegeven voor winterwortel.

Tabel 3.25 Frequenties referentieperiode en klimaatscenario's van weersextremen per klimaatfactor voor winterwortel.

\begin{tabular}{|c|c|c|c|c|c|}
\hline Klimaatfactor & Ref. periode & $\mathrm{G}_{L} \mathbf{2 0 5 0}$ & $W_{H} 2050$ & $\Delta \mathrm{G}_{\mathrm{L}} 2050^{1}$ & $\Delta W_{H} 2050^{1}$ \\
\hline Hevige neerslag WP-5 & 12 & 16 & 19 & 4 & 7 \\
\hline Hevige neerslag WP-10 & 1 & 1 & 2 & 0 & 1 \\
\hline Warme periode $\mathrm{W}-6$ & 0 & 0 & 1 & 0 & 1 \\
\hline
\end{tabular}

${ }^{1}$ Verwachte verandering $(\Delta)$ van de frequenties onder de KNMI-klimaatscenario's (GL 2050 en WH 2050) t.o.v. de referentieperiode 1981-2010. 
De indexen van de klimaatfactoren zijn gepresenteerd in 3.26. Onder het GL-scenario laat alleen hevige neerslag een daling van de index zien, voor nachtvorst wordt bij hoge impact een lichte stijging verwacht. In het $\mathrm{W}_{\mathrm{H}}$-scenario daalt de index voor hevige neerslag (WP-5) en WP-10 (alleen bij hoge impact). Nachtvorst laat onder dit scenario bij hoge impact een beperkte stijging zien.

Tabel 3.26 Geïndexeerde effecten van risico's voor klimaatscenario's ten opzichte van referentieperiode per klimaatfactor voor winterwortel.

\begin{tabular}{|c|c|c|c|c|c|}
\hline Klimaatfactor & Ref. periode & GL 2050 laag & $\mathrm{G}_{\mathrm{L}} 2050$ hoog & $W_{H} 2050$ laag & $W_{H} 2050$ hoog \\
\hline Hevige neerslag WP-5 & 100 & 99 & 87 & 98 & 77 \\
\hline Hevige neerslag WP-10 & 100 & 100 & 100 & 100 & 98 \\
\hline Warme periode $\mathrm{W}-6$ & 100 & 100 & 100 & 100 & 100 \\
\hline
\end{tabular}

\subsubsection{Snijmaïs}

In Tabel 3.27 zijn de frequenties van de klimaatfactoren weergegeven voor snijmaïs.

Tabel 3.27 Frequenties referentieperiode en klimaatscenario's van weersextremen per klimaatfactor voor snijmaïs.

\begin{tabular}{|c|c|c|c|c|c|}
\hline Klimaatfactor & Ref. periode & $\mathrm{G}_{L} 2050$ & $W_{H} 2050$ & $\Delta G_{L} 2050^{1}$ & $\Delta W_{H} 2050^{1}$ \\
\hline Natte periode WP-2 & 12 & 12 & 10 & 0 & -2 \\
\hline Warm en nat W-WP-1 & 0 & 0 & 0 & 0 & 0 \\
\hline Heel warm W-5 & 0 & 0 & 0 & 0 & 0 \\
\hline Nachtvorst F-1 & 14 & 3 & 1 & -11 & -13 \\
\hline
\end{tabular}

${ }^{1}$ Verwachte verandering $(\Delta)$ van de frequenties onder de KNMI-klimaatscenario's (GL 2050 en WH 2050) t.o.v. de referentieperiode 1981-2010.

De indexen van de klimaatfactoren zijn gepresenteerd in Tabel 3.28. In het GL-scenario zijn er geen veranderingen in indexen waar te nemen ten opzichte van de referentieperiode. Het $\mathrm{W}_{\mathrm{H}}$-scenario laat een daling zien van de index bij een droge periode met hoge impact. De indexen laten een stijging zien bij een natte periode.

Tabel 3.28 Geïndexeerde effecten van risico's voor klimaatscenario's ten opzichte van referentieperiode per klimaatfactor voor snijmaïs.

\begin{tabular}{|c|c|c|c|c|c|}
\hline Klimaatfactor & Ref. periode & GL 2050 laag & $\mathrm{G}_{L} 2050$ hoog & $W_{H} 2050$ laag & $W_{H} 2050$ hoog \\
\hline Natte periode WP-2 & 100 & 100 & 100 & 102 & 107 \\
\hline Warm en nat W-WP-1 & 100 & 100 & 100 & 100 & 100 \\
\hline Heel warm W-5 & 100 & 100 & 100 & 100 & 100 \\
\hline Nachtvorst F-1 & 100 & 100 & 100 & 100 & 100 \\
\hline
\end{tabular}




\subsubsection{Gras}

In Tabel 3.29 zijn de frequenties van de klimaatfactoren weergegeven voor gras.

Tabel 3.29 Frequenties referentieperiode en klimaatscenario's van weersextremen per klimaatfactor voor gras.

\begin{tabular}{|c|c|c|c|c|c|}
\hline Klimaatfactor & Ref. periode & $G_{L} 2050$ & $W_{H} 2050$ & $\Delta \mathrm{G}_{\mathrm{L}} 2050^{1}$ & $\Delta W_{H} 2050^{1}$ \\
\hline Warm en nat W-WP-1 & 0 & 0 & 0 & 0 & 0 \\
\hline Droge periode D-3 & 15 & 15 & 24 & 0 & 9 \\
\hline Warme periode $\mathrm{W}-3$ & 11 & 24 & 50 & 13 & 39 \\
\hline
\end{tabular}

${ }^{1}$ Verwachte verandering $(\Delta)$ van de frequenties onder de KNMI-klimaatscenario's (GL 2050 en WH 2050) t.o.v. de referentieperiode 1981-2010.

De indexen van de klimaatfactoren zijn gepresenteerd in Tabel 3.30. Voor het $\mathrm{G}_{\mathrm{L}}$-scenario daalt alleen de index van de klimaatfactor 'warme periode' bij een hoge impact. Onder het $\mathrm{W}_{\mathrm{H}}$-scenario dalen de indexen 'droge periode' en 'warme periode' (bij een hoge impact).

Tabel 3.30 Geïndexeerde effecten van risico's voor klimaatscenario's ten opzichte van referentieperiode per klimaatfactor voor gras.

\begin{tabular}{lccccc} 
Klimaatfactor & Ref. periode & GL. 2050 laag & GL 2050 hoog & WH 2050 laag & WH 2050 hoog \\
Warm en nat W-WP-1 & 100 & 100 & 100 & 100 & 100 \\
\hline Droge periode D-3 & 100 & 100 & 100 & 99 & 97 \\
\hline Strenge vorst F-6 & 100 & 100 & 100 & 100 & 100 \\
\hline Warme periode W-3 & 100 & 100 & 96 & 87
\end{tabular}

\subsection{Conclusies}

Hieronder worden kort conclusies getrokken op basis van bovenstaande resultaten en wordt ingegaan op de twee vragen die in het begin gesteld zijn:

1. Wat zijn de landbouwkundige en financiële klimaatrisico's van eiwitgewassen?

2. Hoe verhouden de risico's van eiwitgewassen zich tot de klimaatrisico's van huidige gewassen, namelijk: poot- en consumptieaardappelen, wintertarwe, suikerbieten, zaaiuien, grove peen, snijmaïs en gras?

\subsubsection{Klimaatrisico's eiwitgewassen}

Voor de bestudeerde eiwitgewassen treedt een wisselend beeld op wat betreft effecten van klimaatveranderingen. Dat betekent soms een verbetering en soms juist een verslechtering in teeltomstandigheden. De meeste effecten van klimaatfactoren zijn binnen een bandbreedte van 90 en 110 te vinden, wat geringe veranderingen impliceert op basis van de uitgangspunten van deze studie.

Eiwitgewassen krijgen in de toekomst voornamelijk meer last van droogte en hitte. De frequenties daarvan en daarmee de risico's gaan in de toekomst toenemen (een index lager dan 100). Het optreden van vorst in het voorjaar neemt juist af, wat een aantal gewassen sterk ten goede komt. De frequenties van natte periodes tijdens de bloeiperiodes die bladvlekkenziekten veroorzaken, nemen af, waardoor de teeltomstandigheden verbeteren (index wordt groter dan 100). De frequentie van hevige neerslag events neem toe, waardoor gewassen meer last krijgen van water op het land of legering.

\subsubsection{Eiwitgewassen versus standaard gewassen}

Bij de standaard gewassen verschilt het effect van klimaatverandering op het risico heel sterk per gewas, maar ook per klimaatscenario. Aardappel en ui krijgen te maken met grote dalingen in de 
indexen door toenemende frequenties in hittegolven, droogte en warm en nat weer.

Winterwortel en gras ervaren dalingen in de index en daarmee een gering toenemend risico. Maïs, wintertarwe en suikerbiet ervaren gematigde effecten, met stijgende en dalende indexen.

Hoogrenderende gewassen (aardappel en zaai-ui, en ook winterwortel) ervaren op basis van deze berekeningen en inschattingen in de toekomst een groot risico. De effecten van klimaatverandering op de lager renderende gewassen zoals gras en wintertarwe zijn klein.

De eiwitgewassen ervaren kleinere risico's dan aardappel, ui en winterwortel. Dat betekent dat als deze risicovolle gewassen in een bouwplan worden vervangen door eiwitgewassen, of hun teeltfrequentie afneemt door eiwitgewassen toe te voegen, het bouwplanrisico voor klimaatverandering verlaagd kan worden. Het invoegen van eiwitgewassen ten koste van wintertarwe, suikerbiet, gras of maïs zal niet leiden tot een aanzienlijke verbetering van de situatie (en dus tot een verlaging van het risico), omdat de klimaatrisico's van deze gewassen in het algemeen overeenkomen met die van de eiwitgewassen. Deze resultaten zijn op basis van een gemiddelde bodem met weersextremen op basis van de klimaatscenario's voor weerstation de Bilt. In andere regio's kan het aantal en type weersextremen sterk verschillen. Verder, op gevoelige grond kan meer schade optreden als gevolg van weersextremen. De gevolgen hiervan vraagt voor verder onderzoek. 


\section{Bodempathogenen}

\subsection{Vermeerdering en schadegevoeligheid}

Vlinderbloemigen zijn zowel gevoelig voor aantasting door allerlei bodempathogenen als door nematoden. Een aantal van deze pathogenen en nematoden is alleen specifiek een probleem in vlinderbloemigen, maar veel zijn ook een probleem bij de teelt van andere gewassen.

\section{Bodempathogenen}

Erwten zijn erg gevoelig voor aantasting van het wortelstelsel door allerlei bodempathogenen. De benaming 'voetziekte' is een verzamelnaam voor deze pathogenen, die verrotten van het wortelstelsel en de stengelbasis veroorzaken. Vaak komen er meerdere soorten pathogenen op één plant voor en ontstaat een onduidelijk ziektebeeld. De ziekte is niet of nauwelijks te bestrijden en is alleen te voorkomen door een zeer ruime vruchtwisseling en daarmee lage teeltfrequentie (Oyarzun, 1991). Schimmels die worden genoemd als veroorzaker van voetziekte zijn:

- $\quad$ Fusarium spp., in het bijzonder Fusarium solani f.sp. pisi, Fusarium oxysporum ras 2, Fusarium avenaceum, Fusarium culmorum en Fusarium graminearum;

- Het 'Ascochyta-complex', gevormd door Phoma medicaginis var. pinodella, Mycosphaerella pinodes en Ascochyta pisi, waarvan de eerste twee het meest voorkomen;

- Phycomycetes: Aphanomyces euteiches, Pythium debaryanum, Pythium ultimum, Pythium irregulare, en Phytophthora spp.;

- $\quad$ Thielaviopsis basicola.

Daarnaast komen Rhizoctonia solani, Sclerotinia sclerotiorum, Cylindrocarpon destructans, Verticillium dahliae, Sclerotium rolfsii en nog vele tientallen andere schimmels voor, die ook betrokken zijn bij het ziektecomplex (Oyarzun, 1991).

De symptomen van voetziekten zijn in drie klassen in te delen:

1. Droogrot: bruine, donkerbruine tot zwarte rotting.

2. Zachtrot: vochtig, doorzichtig goud tot lichtbruine rotting.

3. Zwart wortelrot: zwarte aantasting, uitsluitend beperkt tot de wortels.

Andere peulvruchten dan erwten verschillen in vatbaarheid en tolerantie voor voetziekten. Veldbonen en erwten worden tot dezelfde gewasgroep gerekend met hetzelfde effect op voetziektepathogenen, terwijl Phaseolus-bonen met betrekking tot voetziekten als een aparte gewasgroep worden beschouwd met iets andere effecten op voetziektepathogenen (Tabel 4.1). Door het telen van deze gewassen wordt de pathogeenpopulatie op zijn minst in stand gehouden en de natuurlijke sterfte teniet gedaan. Naast infectie via de grond kunnen veel pathogenen met zaaizaad worden overgedragen.

De spreiding in het verlies van een gewas door voetziekten is groot: het verlies kan beperkt zijn tot $10 \%$, maar ook oplopen tot volledige aantasting van het gewas. Oyarzun (1991) noemt een potentiële opbrengst van erwt van 8 ton per ha, maar 5-6 ton is gebruikelijker, waarbij deze lagere opbrengst een effect kan zijn van een lichte aantasting door voetziekte. 
Tabel 4.1 Overzicht van specialisatie van schimmels die voetziekte veroorzaken op verschillende groepen planten (Bron: Oyarzun (1991)).

\begin{tabular}{|c|c|c|c|c|c|c|c|c|c|}
\hline Erwt & $*$ & $*$ & $* /+$ & $*$ & + & + & + & & $*$ \\
\hline Vicia faba (tuinboon) & $*$ & $*$ & $*$ & + & + & - & + & & $*$ \\
\hline Phaseolus-boon & $*$ & $*$ & $*$ & $*$ & & - & + & & $*$ \\
\hline
\end{tabular}

Het optreden van voetziekte komt op allerlei gronden voor, zowel op goede als minder geschikte landbouwgronden. Er is wel een tendens naar een hogere infectie van het gewas op zwaardere gronden en gronden met een slechtere structuur (Oyarzun, 1991). Teeltmaatregelen zoals later zaaien en een goede ontwatering om plasvorming te voorkomen, kunnen een positief effect hebben op de teelt. Een snelle opbouw van voetziekte wordt in de hand gewerkt door onder andere slemp, slechte drainage, verdichtingen in en onder de bouwvoor, zure gronden of verzurend werkende afbraakprodukten van een voorvrucht, gebrek aan een voldoende actieve antagonistisch werkende microflora of het vóórkomen van synergistisch werkende parasieten. Slemp kan optreden bij scenario's zoals in hoofdstuk 3 beschreven. Er is onderzoek gedaan naar biologische bestrijding met bacteriën en schimmels, maar in Nederland niet naar toepassing hiervan in de praktijk. Verhogen van fysische, chemische en biologische bodemvruchtbaarheid wordt als belangrijk genoemd om problemen met voetziekte te voorkomen. Ruststructuren overleven op gewasresten of gebonden aan organische deeltjes in de grond. Het is belangrijk om besmette gewasresten te verwijderen of volledig onder te werken (Oyarzun, 1991).

Een aantal van de genoemde schimmels kunnen, naast vermeerdering of problemen bij de teelt van vlinderbloemigen, ook schade veroorzaken in andere gewassen. Dit geldt bijvoorbeeld voor Rhizoctonia solani AG 2-2 IIIB, Sclerotinia sclerotiorum en Verticillium dahliae (Figuur 4.1). Aanwezigheid van deze schimmels kan een reden zijn om de teelt van vlinderbloemigen niet vlak voor een gevoelige teelt uit te voeren. Zo is luzerne een goede voorvrucht voor maïs, maar minder voor aardappel (proef met Bintje), een effect dat ook na drie jaar nog zichtbaar was (van der Schans, 1998). Waarschijnlijk hield dit verband met de aanwezigheid van $V$. dahliae. Een uitgebreid schimmelschema is binnenkort beschikbaar op de website Best4Soil.eu.

Vergeleken met andere gewassen is er weinig gedaan aan veredeling van vlinderbloemigen. Toch zijn er de laatste jaren wel ontwikkelingen op dit gebied gaande om interacties met pathogenen en nematoden te ontrafelen en betrokken genen te karakteriseren. Er zijn verschillen in pathogeniteit en waardplantreeks tussen isolaten van een schimmelsoort, wat betekent dat voorzichtigheid geboden is bij het vertalen van onderzoeksresultaten uit andere gebieden (Levenfors et al., 2003; Heyman et al., 2013; Quillevere-Hamard et al., 2018). Om daadwerkelijk te komen tot het ontwikkelen van resistente rassen is het nodig om variatie in pathogenen in kaart te brengen en mogelijke bronnen van resistentie in verwante plantensoorten op te sporen (Rubiales et al., 2015). 


\begin{tabular}{|c|c|c|c|c|c|}
\hline & 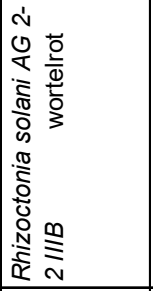 &  & 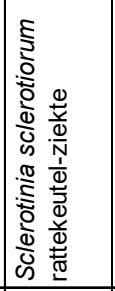 & 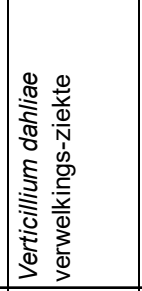 & \\
\hline Akkerbouw & $\mathrm{D},(\mathrm{K}, \mathrm{Z},)_{\mathrm{ZA}}$ & $\mathrm{D}, \mathrm{K}, \mathrm{Z}, \mathrm{ZA}$ & $\mathrm{D}, \mathrm{Z}, \mathrm{ZA}$ & $\mathrm{D}, \mathrm{K}, \mathbf{Z}, \mathbf{Z A}$ & \\
\hline aardappel & $\cdots$ & $?$ & .• & $\cdots$ & aardappel \\
\hline suikerbiet & $\cdots$ & $?$ & $\cdot$ & - & suikerbiet \\
\hline ui & - & $?$ & - & - & ui \\
\hline maïs & $\cdots$ & $?$ & - & $\cdot$ & maïs \\
\hline wintertarwe & - & $?$ & - & • & wintertarwe \\
\hline zomertarwe & - & $?$ & - & - & zomertarwe \\
\hline wintergerst & $?$ & $?$ & - & $\cdot$ & wintergerst \\
\hline zomergerst & $?$ & $?$ & - & $\cdot$ & zomergerst \\
\hline rogge & $?$ & $?$ & - & $\cdot$ & rogge \\
\hline luzerne & - & $\cdots$ & $?$ & $\ddot{*}$ & luzerne \\
\hline Groenten & & & & & Groenten \\
\hline erwt (conserven) & $?$ & $\cdot$ & - & $\cdot$ & erwt (conserven) \\
\hline stamslaboon & $\ddot{*}$ & $\cdot$ & $\ddot{*}$ & - & stamslaboon \\
\hline veld-/tuinboon & $\ddot{*}$ & $\cdot$ & $\cdot$ & $\ddot{*}$ & veld-/tuinboon \\
\hline peen & $\ldots$ & - & $\ddot{*}$ & - & peen \\
\hline witlof & $?$ & $\cdot$ & $\ddot{*}$ & $\cdot$ & witlof \\
\hline Groenbemesters & & & & & Groenbemesters \\
\hline bladrammenas & - & $\cdot$ & $\cdots$ & $?$ & bladrammenas \\
\hline gele mosterd & $\ddot{*}$ & $\cdot$ & $\cdots$ & $?$ & gele mosterd \\
\hline engels raaigras & $\cdots$ & $?$ & - & $?$ & engels raaigras \\
\hline italiaans raaigras & $\cdots$ & $?$ & - & $?$ & italiaans raaigras \\
\hline witte klaver & $\cdots$ & $\cdot$ & $?$ & $\ddot{*}$ & witte klaver \\
\hline tagetes & $\cdots$ & $\cdot$ & $?$ & $?$ & tagetes \\
\hline japanse haver & $?$ & $?$ & - & $?$ & japanse haver \\
\hline
\end{tabular}

\begin{tabular}{|c|l|}
\hline \multicolumn{2}{|l|}{ Legenda vermeerdering } \\
\hline$?$ & onbekend \\
\hline- & natuurlijke afname \\
\hline$\cdot$ & weinig \\
\hline$\cdot \cdot$ & matig \\
\hline$\cdot \cdot$ & sterk \\
\hline
\end{tabular}

\begin{tabular}{|c|l|c|}
\hline \multicolumn{2}{|l|}{ Legenda schade } \\
\hline & onbekend & \\
\hline & geen & $0-5 \%$ \\
\hline & weinig & $5-15 \%$ \\
\hline & matig & $15-33 \%$ \\
\hline & sterk & $>33 \%$ \\
\hline
\end{tabular}

\begin{tabular}{|l|l|}
\hline$D$ & Dalgrond \\
\hline$K$ & Klei \\
\hline$Z$ & Zand \\
\hline ZA & zavel \\
\hline
\end{tabular}

Figuur 4.1 Vermeerdering van en schade door bodemschimmels die naast vlinderbloemigen ook bij andere gewassen een probleem kunnen vormen (Lamers et al., 2016).

\section{Nematoden bij vlinderbloemigen in relatie tot andere akkerbouwgewassen}

Bij het opnemen van vlinderbloemigen in een bouwplan zal rekening gehouden moeten worden met aan- of afwezigheid van een aantal nematodensoorten. Erwten en veldbonen zijn goede waardplanten voor meerdere soorten plantparasitaire nematoden die ook problemen kunnen geven in andere gewassen. Afhankelijk van de aanwezigheid van deze nematodensoorten, zal een bouwplan hier op moeten worden aangepast. In Aaltjesschema (www.aaltjesschema. $\mathrm{nl}$ ) is voor veel van de vlinderbloemigen informatie beschikbaar over de vermeerdering van belangrijke nematodensoorten, maar over schadegevoeligheid van de vlinderbloemigen is minder bekend (Figuur 4.2).

- Meloidogyne hapla (Noordelijk wortelknobbelaaltje) vermeerdert sterk op erwt, stamslaboon, veld- en tuinboon, maar ook op aardappel en suikerbiet. Erwt, ui en peen zijn sterk schadegevoelig voor deze nematode, terwijl aardappel en suikerbiet matig schadegevoelig zijn. Maïs, tarwe, gerst en Engels en Italiaans raaigras zijn niet-waardplanten die ook geen schade ondervinden.

- Voederwikke vermeerdert de quarantainesoort Meloidogyne fallax (Bedrieglijk maïswortelknobbelaaltje) sterk. Erwt vermeerdert zowel M. fallax als de quarantainesoort $M$. chitwoodi (Maïswortelknobbelaaltje) weinig, maar is wel sterk schadegevoelig voor M. fallax. Bij witte klaver is de vermeerdering van beide soorten rasafhankelijk en van rode klaver is geen informatie bekend.

- Pratylenchus penetrans (Wortellesieaaltje) vermeerdert sterk op bijna alle genoemde vlinderbloemigen en daarnaast op aardappel, ui en maïs. Veel andere akkerbouwgewassen vermeerderen deze nematode matig. Erwt, stamslaboon, aardappel en maïs zijn matig schadegevoelig, terwijl ui en peen sterk schadegevoelig zijn. Opnemen van vlinderbloemigen in het bouwplan vormt een extra risico bij aanwezigheid van $P$. penetrans. De teelt van Tagetes patula kan de aanwezigheid van het wortellesieaaltje dusdanig sterk verminderen, dat deze nematode geen problemen meer geeft in een volgteelt (van Leeuwen-Haagsma et al., 2019). 
Bijkomend nadeel van veel vlinderbloemigen is de vermeerdering van Verticillium dahlia, die in combinatie met $P$. penetrans de schade in bijvoorbeeld aardappel versterkt.

- Ditylenchus dipsaci (Stengelaaltje) vermeerdert sterk op bijna alle genoemde vlinderbloemigen. Luzerne, witte en rode klaver, suikerbiet en ui zijn sterk schadegevoelig, terwijl aardappel, maïs en peen matig schadegevoelig zijn. Gerst vermeerdert $D$. dipsaci niet en ondervindt geen schade, Engels en Italiaans raaigras vermeerderen weinig en ondervinden eveneens geen schade. Aangezien $D$. dipsaci al in zeer lage dichtheden schade kan toebrengen, vormt de teelt van vlinderbloemigen een extra risico op percelen waar deze nematode voorkomt.

- $\quad$ Erwt vermeerdert Heterodera betae (Geel bietencystenaaltje) niet, maar is wel sterk gevoelig voor schade door deze nematode. Het is aan te raden om minstens twee jaar te wachten na de teelt van een sterk vermeerderend gewas zoals biet, diverse vlinderbloemigen en kool vóór erwt, stamslaboon en veld- of tuinboon te telen.

- $\quad$ Erwt en veld- en tuinboon vermeerderen Heterodera goettingiana (Erwtencystenaaltje) sterk. De nematode blijft lang in de grond aanwezig en gaat vaak samen met schade door Fusarium. Erwt is sterk schadegevoelig en veld- en tuinboon weinig, maar er is geen informatie over vermeerdering en schadegevoeligheid van andere vlinderbloemigen. Deze nematode staat niet bekend als een probleem dat vaak voorkomt en aanwezigheid vormt geen risico voor nietvlinderbloemige akkerbouwgewassen.

- Informatie over de vermeerdering van trichodoriden op vlinderbloemigen en schadegevoeligheid is beperkt voor handen. Het is belangrijk om te weten welke soort aanwezig is in een perceel, omdat vermeerdering en schadegevoeligheid van gewassen soortafhankelijk is. Stamslaboon is een sterke vermeerderaar van Paratrichodorus pachydermus en Trichodorus primitivus en een matige vermeerderaar van Paratrichodorus teres. Witte klaver is een sterke vermeerderaar van $P$. teres en voederwikke van $T$. primitivus. Erwt, stamslaboon, veld- en tuinboon zijn zelf matig gevoelig voor schade door trichodoriden. De teelt van deze vlinderbloemigen vormt wel een risico voor de teelt van andere gewassen: bij aanwezigheid van $P$. teres voor aardappel, bij $P$. pachydermus en $T$. primitivus voor suikerbiet en ui en bij $T$. similis voor ui.

- Trichodoriden zijn vooral bekend als vector van virussen zoals het tabaksratelvirus (TRV), waarbij verschillende trichodoriden verantwoordelijk zijn voor overdracht van verschillende serotypen van het virus. Het serotype dat wordt overgebracht door $P$. teres vermeerdert sterk in stamslaboon en witte klaver, matig in luzerne en weinig in erwt. Er is weinig bekend over gevoeligheid van vlinderbloemigen voor TRV. Van de akkerbouwgewassen is alleen aardappel sterk schadegevoelig voor TRV.

- $\quad$ Het vroegeverbruiningsvirus (PEBV) bij erwt wordt overgedragen door $P$. pachydermus en $P$. teres. Het is aan te raden om geen sterke vermeerderaar zoals graan in het bouwplan op te nemen vóór de teelt van erwt.

Een aantal van de nematodensoorten vormt voornamelijk op zandgronden een probleem. Dit geldt voor $H$. betae, Meloidogyne, Pratylenchus en trichodoriden. De aanwezigheid van trichodoridensoorten is daarnaast regio gebonden. In het Noordoostelijk en Zuidoostelijk zandgebied zijn vooral $P$. pachydermus en $T$. similis aanwezig, maar op lichtere gronden in het Zuidwestelijk en Centraal zeekleigebied komen ook $P$. teres en $T$. primitivus voor. Op de lichte gronden in de kop van Groningen lijkt $T$. primitivus de hoofdrol te spelen. 

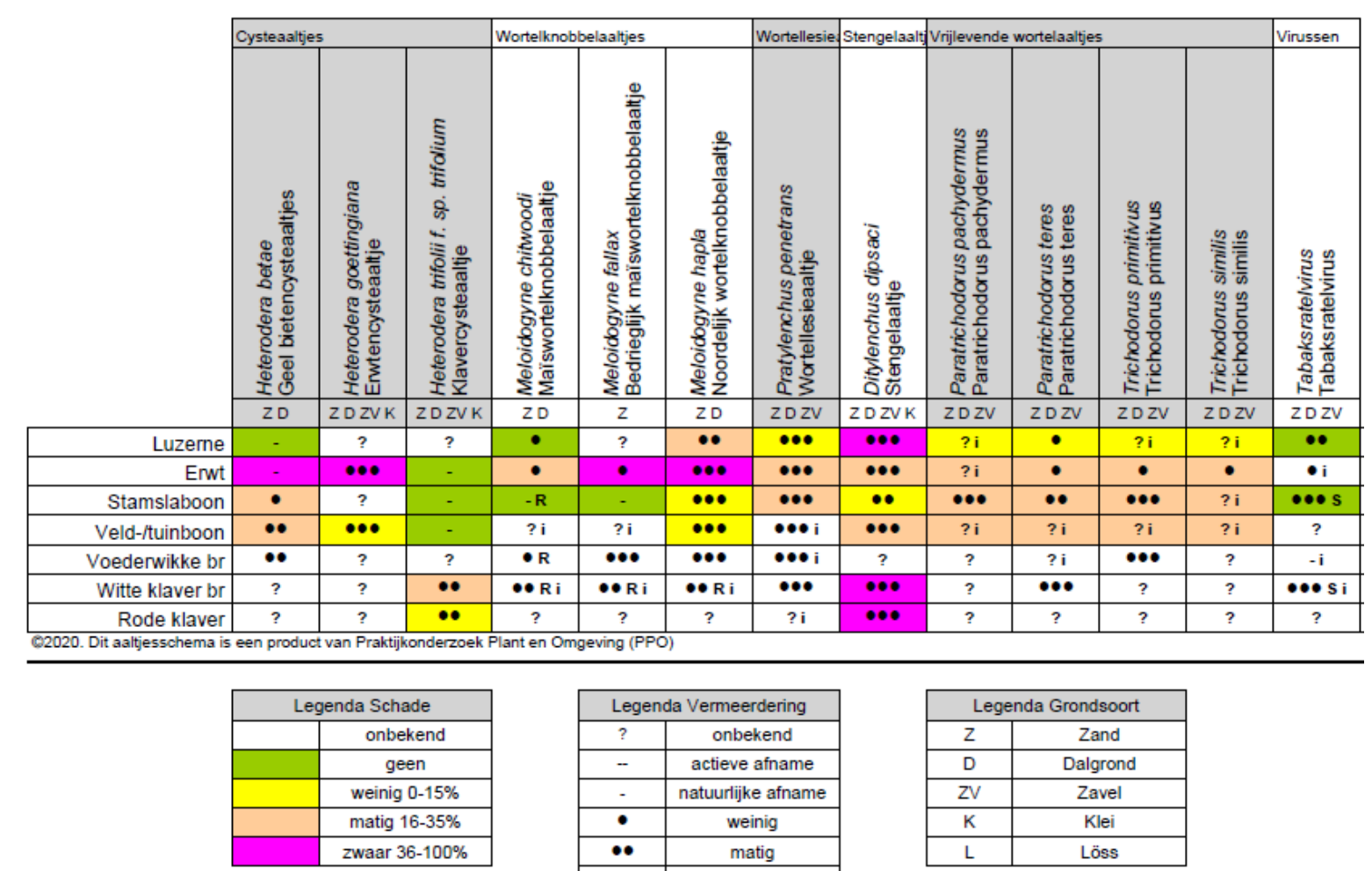

\begin{tabular}{|c|c|}
\hline \multicolumn{2}{|c|}{ Legenda Vermeerdering } \\
\hline$?$ & onbekend \\
\hline- & actieve afname \\
\hline- & natuurlijke afname \\
\hline$\bullet$ & weinig \\
\hline$\bullet \bullet$ & matig \\
\hline$\bullet \bullet \bullet$ & sterk \\
\hline R & Rasafhankelijk \\
\hline S & Serotypeafhankelijk \\
\hline i & enige informatie \\
\hline
\end{tabular}

\begin{tabular}{|c|c|}
\hline \multicolumn{2}{|c|}{ Legenda Grondsoort } \\
\hline$Z$ & Zand \\
\hline D & Dalgrond \\
\hline ZV & Zavel \\
\hline K & Klei \\
\hline L & Löss \\
\hline
\end{tabular}

Figuur 4.2 Vermeerdering van en schade door nematoden die naast vlinderbloemigen ook bij andere gewassen een probleem kunnen vormen (www.aaltjesschema.nl, augustus 2020).

\subsection{Effecten van klimaatverandering}

Effecten van klimaatverandering zijn 's winters vooral merkbaar in het uitblijven van vorst en in het groeiseizoen in hitte, langere droogteperiodes en extremere regenval, zoals beschreven in hoofdstuk 3.1. Dit heeft zowel direct als indirect invloed op het optreden van ziekten en plagen. In Hoofdstuk 3.3.1 is een beschrijving gegeven van de verwachte effecten van bepaalde weersomstandigheden en klimaatfactoren op problemen met ziekten en plagen bij de teelt van vlinderbloemigen. Met de verwachte toekomstige frequentie van deze klimaatfactoren is een inschatting gemaakt van het optreden van deze ziekten in de toekomst (Hoofdstuk 3.3.1). In internationale literatuur worden algemene verwachtingen genoemd over verschillende facetten in de teelt van een gewas waarop klimaatverandering gevolgen kan hebben (Juroszek \& von Tiedemann, 2011) en die ook van invloed kunnen zijn op verspreiding en schade door ziekten en plagen. De onderstaande verwachtingen gelden zowel voor vlinderbloemigen als voor andere gewassen (Juroszek \& von Tiedemann, 2011).

- Wellicht verandert de verspreiding van pathogenen als gevolg van klimaatverandering (frequentie, dichtheid, afstand, snelheid). Dit kan door verandering van het mogelijke leefgebied, maar bijvoorbeeld ook door verspreiding via de lucht door het optreden van stormen. Een voorbeeld hiervan is de verspreiding van Xanthomonas citri subsp. citri over citrusboomgaarden tijdens een orkaan in Florida in 2005 (Luck et al., 2011).

- Potentiële toename in biomassa van een gewas als gevolg van $\mathrm{CO}_{2}$-toename, indien er voldoende water beschikbaar is. Specifiek voor vlinderbloemigen is, dat ze kunnen profiteren van een verhoogd $\mathrm{CO}_{2}$-gehalte door toename van de stikstoffixatie (Yadav et al., 2010). Er moet meer aandacht worden besteed om overleven van inoculum op een grotere hoeveelheid gewasresten te vermijden of te beperken.

- Waardplantresistentie tegen pathogenen en nematoden kan worden doorbroken bij hogere temperatuur. Daarnaast kunnen veranderingen in morfologie en fysiologie effect hebben op resistentie van een gewas. Een hogere temperatuur kan snellere evolutie van pathogenen veroorzaken en leiden tot een vervroegd doorbreken van resistentie van de plant. 
- Door hogere temperatuur kan het nodig zijn om vaker te irrigeren; afhankelijk van de methode waarop dit gebeurt kan dat effect hebben op pathogenen. Voor aaltjesontwikkeling en verplaatsing is iets warmere grond met een vochtgehalte rond veldcapaciteit gunstig.

- Bij solarisatie wordt de grond afgedekt om zonne-energie op te vangen ter bestrijding van bodempathogenen en nematoden. Deze maatregel wordt wellicht effectiever bij hogere temperaturen, onder voorbehoud dat de grond voldoende vochtig is.

- Effectiviteit van biologische gewasbescherming kan verminderen door grotere variabiliteit in omstandigheden.

- Effectiviteit van chemische gewasbeschermingsmiddelen kan veranderen (bij middelen met contactwerking: door intensievere regenval kan het middel afregenen, en afhankelijk van de snelheid van gewasgroei zijn vaker of minder vaak bespuitingen nodig; bij systemische middelen: meer kennis nodig van het opnameproces via het blad, effectiviteit afhankelijk van omstandigheden; de afbraak van granulaten die tegen aaltjes worden ingezet is temperatuurafhankelijk).

Droogte en hitte kunnen bij tarwe, gerst en maïs tot een verminderd niveau van resistentie tegen schimmelziekten en virussen leiden (Seidel, 2016), wat een rol kan gaan spelen bij klimaatverandering. Dit wordt ook als een probleem genoemd voor andere gewassen met temperatuurgevoelige resistentiegenen, zoals resistentie tegen wortelknobbelaaltjes in tomaat (Newton et al., 2012). Zo is resistentie gebaseerd op het gen Mi-1 tegen meerdere Meloidogynesoorten inactief bij een temperatuur boven $28^{\circ} \mathrm{C}$ tijdens of in de eerste dagen tot week na infectie, al lijkt wel dat de hogere temperatuur gedurende langere periode moet aanhouden (Newton et al., 2012; Verdejo-Lucas et al., 2013). Resistentie gebaseerd op andere genen is bij die hogere temperatuur nog wel actief (Newton et al., 2012). Ook de werkzaamheid van resistentiegenen tegen virussen, bacteriën en schimmels is vaak temperatuurafhankelijk, waarbij een deel inactief is bij temperaturen boven 27$28^{\circ} \mathrm{C}$ (Newton et al., 2012). Daarnaast kan droogte en hitte bij maïs de aantasting met Aspergillussoorten en als gevolg daarvan het aflatoxinegehalte van de maïskorrels verhogen. Een maatregel die genomen kan worden om sommige ziekten en plagen te omzeilen, of bijvoorbeeld periodes van droogte, is het aanpassen van plant- of zaaitijdstip.

Een hogere temperatuur in de zomer zal betekenen dat sommige soorten nematoden een extra generatie in een jaar kunnen voltooien, al zal dit alleen gebeuren bij een voldoende vochtige grond. De optimumtemperatuur voor Meloidogyne chitwoodi en trichodoriden ligt tussen 20 en $25^{\circ} \mathrm{C}$, maar die van M. hapla en Pratylenchus penetrans tussen 25 en $30^{\circ} \mathrm{C}$ (Winfield \& Cooke 1975; Santo \& O'Bannon 1981; Mizukubo \& Adachi 1997). De optimumtemperatuur van Ditylenchus dipsaci is juist wat lager, waarschijnlijk rond $20^{\circ} \mathrm{C}$ (Hajihassani et al. 2017). Tot nog toe zijn tropische soorten als $M$. luci en M. enterolobii niet in Nederland aangetroffen, maar deze soorten zijn wel in Zuid-Europa aangetroffen en op de 'Alert list' van de EPPO (European and Mediterranean Plant Protection Organization) geplaatst. Er wordt niet verwacht dat deze soorten zich hier door klimaatverandering snel zullen vestigen, al blijft waakzaamheid geboden.

Het uitblijven van vorst in de winter kan problemen met plantparasitaire nematoden vergroten. In het verleden zorgde vorst in de grond voor het bevriezen van aardappels die achterbleven na de oogst. In het huidige klimaat komt vorst minder vaak voor en zorgen de niet-geoogste aardappels voor opslag in de opvolgende teelt. Wanneer deze planten niet worden verwijderd, kunnen onder andere aardappelcysteaaltjes (Globodera spp.) zich op deze planten vermeerderen. Hiermee wordt het effect van een rotatie met andere gewassen teniet gedaan en kunnen de aardappelcysteaaltjes een probleem vormen in een latere aardappelteelt. Wanneer een kortere winter vroeger zaaien of planten en later oogsten betekent, wordt het groeiseizoen verlengd. In combinatie met het sneller doorlopen van de levenscyclus van nematoden, kan dit voor sommige soorten betekenen dat er meerdere generaties per gewascyclus mogelijk zijn (Newton et al. 2012). De nematodenpopulaties kunnen over een langere periode opbouwen en de periode van wintersterfte is korter, waardoor de begindichtheid bij aanvang van de volgende teelt hoger zal zijn. Daarnaast kan ook bedekking in de winter met groenbemesters die niet of later doodvriezen voor vermeerdering in plaats van wintersterfte leiden. $\mathrm{Er}$ zijn ook nematodensoorten met een lager temperatuuroptimum, wat kan betekenen dat er een verschuiving kan optreden in de betekenis van verschillende soorten (Jones et al. 2017).

Het effect van sterke regenval hangt af van de periode waarin dit plaats vindt. Regenval kan bijvoorbeeld het vochtgehalte van het graan verhogen of het gewas doen legeren, maar kan ook kwaliteitsverlies veroorzaken door het kiemen van korrels in de aren. Tijdens de bloei van graan zijn de graankorrels het meest vatbaar voor een infectie met Fusarium, met een hoger niveau van het mycotoxine DON (Deoxynivalelol) tot gevolg. Vervroegen van bloei en afrijping van tarwe met 1-2 weken kan tot een verdrievoudiging van de huidige DON-concentraties in NW-Europa leiden (Moretti 
et al., 2019). Weersomstandigheden die tot een latere oogst leiden, zoals regen, verhogen ook de DON-belasting van de aren na infectie met Fusarium. Ook voor vlinderbloemigen geldt, dat ze kunnen legeren bij zware regenval en een hogere gevoeligheid voor infectieziekten tijdens de bloeiperiode (zie Hoofdstuk 3.3.1).

Schadelijke effecten van abiotische en biotische stressoren zijn niet per definitie additief. Er kan ook een compensatiereactie optreden, waarbij een opvolgende stressfactor een geringer effect heeft dan wanneer deze alleen was opgetreden.

Klimaatverandering heeft niet alleen direct gevolgen voor de aantasting door pathogenen, maar kan ook leiden tot complexe interacties en oorzaak-gevolg relaties. Zo kan voorjaarsdroogte in april leiden tot verminderde beschikbaarheid van nutriënten voor de plant en daarmee een grotere vatbaarheid voor schimmelziekten (zwakteparasieten) of een verminderd compensatievermogen. Andere ziekten en plagen, zoals meeldauw of enige bladluissoorten, gedijen juist beter op een goed verzorgd gewas.

Het effect van klimaatverandering op aantasting door insecten verloopt vaak via een effect op de plant. De invloed van droogte en hitte op de ontwikkeling van bladluizen wordt veroorzaakt door een verandering van de concentratie van oplosbare eiwitten, oplosbare koolhydraten en zetmeel in de plant.

\subsection{Aanbeveling voor bouwplannen}

In Nederland wordt geadviseerd niet vaker dan eens in de zes jaar erwten te telen, maar in Engeland en Frankrijk is het advies eens in de vijf jaar (Oyarzun 1991). Veldbonen en erwten worden tot dezelfde gewasgroep gerekend met hetzelfde effect op voetziektepathogenen, terwijl Phaseolus-bonen als een aparte gewasgroep worden beschouwd. Bij afwisselen van erwten en veldbonen enerzijds en Phaseolus-bonen anderzijds, kan de vruchtwisseling mogelijk iets worden vernauwd, al zal het succes afhankelijk zijn van de aanwezige schimmels en plagen. Rassenkeuze kan ook een rol spelen bij het voorkomen van problemen met voetziekte. Er zijn veel verschillende rassen doperwten beschikbaar, die verschillen in vatbaarheid voor voetziekte. Het rassensortiment van droog te oogsten groene erwten is veel kleiner. Pathogenen die voetziekte veroorzaken kunnen zeer persistent zijn en ook 1520 jaar na afloop van een teelt opspelen. Om die reden biedt een ruime vruchtwisseling geen zekerheid bij de teelt van erwten op een perceel dat eenmaal besmet is geraakt met voetziekte.

Tabel 4.2 Minimaal aangeraden vruchtwisseling voor een aantal vlinderbloemigen.

\begin{tabular}{lc} 
Gewas & Minimale vruchtwisseling (jaren) \\
Erwten & $6-8$ \\
\hline Veldbonen & $4-6$ \\
\hline Lupine & $4-6$ \\
\hline Luzerne & $4-6$ \\
\hline Peulvrucht op peulvrucht & $4-5$ \\
\hline Peulvrucht op grasklaver of luzerne & $2-3$
\end{tabular}

Bron: Prins \& van Krimpen (2007); van der Schans (1998). 


\section{$5 \quad$ Bouwplannen per regio}

Voor deze studie zijn vier regio's gedefinieerd. Dit betreft Noord-Oost Nederland (NON), Zuid-Oost Nederland (ZON), Centraal Nederland (CEN) en Zuid-West Nederland (ZWN). Voor de uitgangspunten van de regio's is voor NON de provincie Drenthe gekozen, voor ZON het zuidelijk veehouderij gebied, voor CEN de Noordoostpolder en voor ZWN de landbouwgebieden Zuidwestelijk akkerbouw en Zuidwest-Brabant (Tabel 5.1). Figuur 5.1 geeft een overzicht van de landbouwgebieden. De grondsoort in NON en ZON is zandgrond met fosfaattoestand ruim voldoende, in CEN en ZWN kleigrond met fosfaattoestand neutraal.

Tabel 5.1 Gekozen regio's voor de bouwplanberekeningen.

\begin{tabular}{llll} 
Regio code & Omschrijving & Specificering gebied & Eenheid \\
NON & Noordoost-Nederland, zand & Drenthe & Provincie \\
\hline ZON & Zuidoost-Nederland, zand & Zuidelijk veehouderij gebied & Landbouwgebied \\
\hline CEN & Centraal-Nederland, klei & Noordoostpolder & Gemeente \\
\hline ZWN & Zuidwest-Nederland, klei & Zuidwestelijk akkerbouw en Zuidwest-Brabant & Landbouwgebied \\
\hline
\end{tabular}
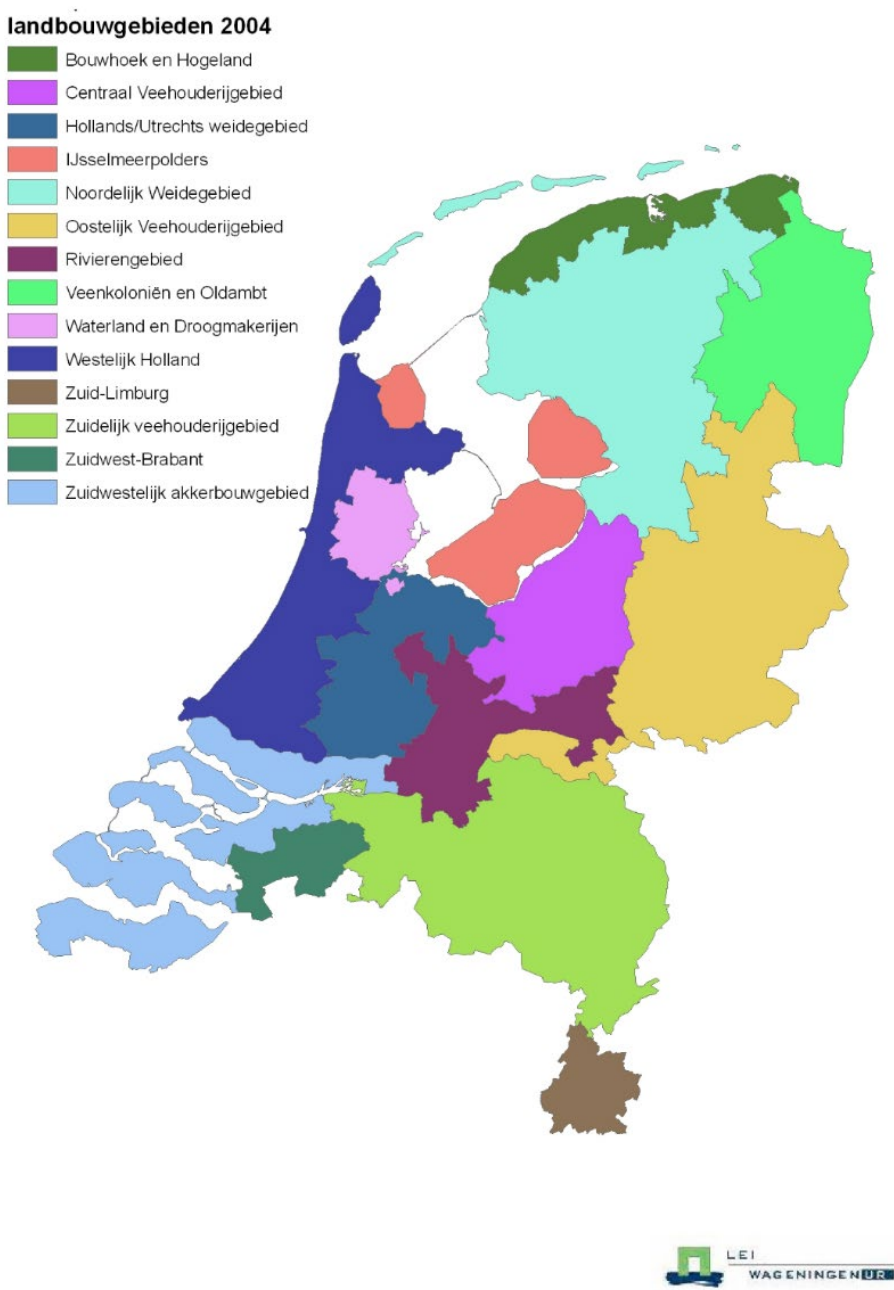

Figuur 5.1 Landbouwgebieden in Nederland. 
In dit hoofdstuk worden voor de vier regio's de referentiebouwplannen en een aantal varianten beschreven die zijn doorgerekend. De varianten zijn opgesteld vanuit het oogpunt van gezamenlijk grondgebruik en/of de teelt van meer eiwit. Bij de keuze van varianten voor de betreffende regio's is rekening gehouden met de situatie in de regio's. Hiervoor zijn experts uit de regio's geïnterviewd. Zie Bijlage 1 voor geïnterviewden.

Bij de grondgebruiksvarianten is gekeken naar het aandeel blijvend grasland, de keuze voor uitwisseling van akkerbouwgewas met gras of maïs en ruimere teeltfrequenties op het akkerbouw- en melkveebedrijf. Voorwaarde bij het opstellen van de varianten is het handhaven/verbeteren van de bodemkwaliteit, waarbij bodemgezondheid en organische stofaanvoer een belangrijke rol spelen. Daarnaast speelt bij dit soort varianten ook de koolstofopslag in de bodem een rol, met name wanneer het aandeel grasland en de verhouding blijvend en tijdelijk grasland verandert.

Bij de varianten om meer eiwit te telen (eiwitteelt) zijn verschillende opties meegenomen, zoals de teelt van gras-rode klaver i.p.v. gras en de teelt van luzerne en zaadleguminosen (o.a. veldbonen en erwten). Het doel is hierbij om meer eiwit op eigen grond te telen. Dit kan voor veevoederdoeleinden zijn, maar ook voor de humane consumptie. Wat betreft veevoer heeft de melkveehouderijsector aangegeven dat minimaal $65 \%$ van het gebruikte eiwit van eigen grond (of van naburige akkerbouwers) moet komen (Visie Grondgebondenheid Melkveehouderij, 2018).

De verschillende opties zijn verdeeld over de vier regio's om te voorkomen dat er te veel herhaling plaatsvindt. In Tabel $\mathbf{5 . 2}$ is een overzicht gegeven van de bouwplanvarianten. Hieronder wordt een toelichting gegeven per regio.

\subsection{Noordoost-Nederland (NON)}

\section{Referentie}

Uitgangspunt is een melkveebedrijf met derogatie ( $80 \%$ gras en $20 \%$ maïs) en een akkerbouwbedrijf met $1: 2$ zetmeelaardappelen (referentie, uitgangssituatie). Omdat er in de regio al veel samenwerking plaatsvindt, wordt in de referentie uitgegaan van samenwerking (referentie, samenwerking, NON-1), waarbij op het melkveebedrijf een deel van de maïs is vervangen door pootaardappel. Het areaal maïs dat de melkveehouder mist, wordt geteeld op het akkerbouwbedrijf en vervangt een deel van de zomergerst. De akkerbouwer handhaaft de 1:2 zetmeelaardappelen en gaat in de samenwerkingssituatie meer aardappelen (naast zetmeelaardappelen ook pootaardappelen) telen dan vóór de samenwerking. De referentiesituatie is mede gebaseerd op de resultaten van een workshop over samenwerking akkerbouw en melkveehouderij in Drenthe (De Wolf et al., 2018).

\section{Varianten}

\section{Gezamenlijk grondgebruik}

- Meer blijvend grasland (NON-2)

Door de grasperiode in het wisselbouw korter te maken, kan het aandeel blijvend grasland worden verhoogd.

- $\quad$ Ruimere teeltfrequentie

In de referentie is uitgegaan van een $1: 2$ zetmeelaardappelteelt. Verruiming is 0. a. vormgegeven door een 1:3 teelt op het akkerbouwbedrijf, waarbij de pootgoedteelt op het melkveebedrijf is vervangen door zetmeelaardappel teneinde het areaal zetmeelaardappelteelt zo veel mogelijk te handhaven (NON-3).

Daarnaast wordt een variant meegenomen met een volledige integratie van de vruchtwisseling op beide bedrijven met een 1:4 teelt aardappelen (zoals ook in De Wolf et al. (2018) is beschreven). $\mathrm{Er}$ is dan alleen nog tijdelijk grasland. Hierbij worden twee sub-varianten meegenomen:

1) handhaving derogatie op melkveebedrijf (NON-4)

2) laten vallen derogatie (hoger aandeel voedergewassen en minder gras, NON-5). 
De laatste optie is met name interessant op bedrijven op droogtegevoelige grond, waar de voederwaarde-opbrengst van voedergewassen als snijmaïs en voederbieten hoger is dan van gras. In dit voorbeeld is een deel van het gras vervangen door voederbiet, waardoor het aandeel gras daalt naar $70 \%$.

Meer eiwitteelt

- $\quad$ Op het melkveebedrijf is een variant meegenomen waarin de helft van de maïs is vervangen door veldboon (NON-6). Deze wordt geteeld in een wisselbouwsysteem met 4-jarig grasland en pootaardappel. Er is gekozen voor 4-jarig grasland om een voldoende ruime teeltfrequentie van veldbonen te realiseren.

- Op het akkerbouwbedrijf zijn varianten doorgerekend waarbij de maïs (van de veehouder) is vervangen door veldbonen (NON-7). In dat geval wordt de veldboon geteeld voor veevoerdoeleinden. $\mathrm{Er}$ is ook een variant meegenomen waarin de veldboon een deel van de zomergerst vervangt en wordt afgezet voor humane doeleinden (NON-8).

\section{Groenbemesters}

- Na zomergerst en veldbonen wordt op het akkerbouwbedrijf Japanse haver gezaaid als groenbemester.

- $\quad$ Na snijmaïs wordt Japanse haver ingezaaid als verplicht vanggewas, m.u.v. varianten NON-4 en NON-5, waar na de maïs het nieuwe gras wordt ingezaaid.

\subsection{Zuidoost Nederland (ZON)}

\section{Referentie}

Uitgangspunt is een melkveebedrijf met derogatie ( $80 \%$ gras en $20 \%$ maïs) en een akkerbouwbedrijf met 1:4 consumptieaardappelen en industriegroenten (referentie, uitgangssituatie). Omdat er in de regio al veel samenwerking plaatsvindt wordt in de referentie uitgegaan van samenwerking (referentie, samenwerking, NON-1), waarbij op het melkveebedrijf een deel van de maïs is vervangen door consumptieaardappel. Het areaal maïs dat de melkveehouder mist, wordt geteeld op het akkerbouwbedrijf. Deze maïs werd ook voor aanvang van de samenwerking al door de akkerbouwer op zijn bedrijf geteeld, omdat deze qua saldo vaak gunstiger is dan graan en er in de regio relatief veel behoefte is aan snijmaïs. De akkerbouwer handhaaft de 1:4 consumptieaardappelen op zijn eigen bedrijf en gaat in de samenwerkingssituatie meer aardappelen telen dan voor de samenwerking.

\section{Varianten}

\section{Gezamenlijk grondgebruik}

- $\quad$ Meer blijvend grasland (ZON-2 t/m ZON-4)

In de referentiesituatie is het aandeel blijvend grasland laag (20\%). Er zijn varianten doorgerekend met een hoger aandeel blijvend grasland door het wisselbouwdeel anders in te richten. Dat laatste is gedaan door de bouwlandgewassen achter elkaar te telen en door de duur van de grasperiode te verlagen. Bij het akkerbouwbedrijf verandert niets bij deze varianten.

\section{Meer eiwitteelt}

- $\quad$ Op het melkveebedrijf worden de volgende varianten bekeken: 1) gras-rode klaver i.p.v. gras in het wisselbouwsysteem (ZON-5), en 2) voederbieten i.p.v. maïs (ZON-6). In het eerste geval wordt een vlinderbloemige toegevoegd. Voederbieten hebben een relatief hoge voederwaardeopbrengst met name onder droge omstandigheden. Verder nemen ze veel stikstof op, waardoor de risico's van uitspoeling in wisselbouwsystemen kan worden beperkt (met name in het eerste jaar na scheuren).

- $\quad$ Op het akkerbouwbedrijf wordt een variant meegenomen waarbij maïs vervangen wordt door wintergerst (ZON-7). Hiermee wordt meer eiwit geproduceerd dan met maïs en dit gewas is gunstiger voor de bodemkwaliteit (meer organische stof en vroegere oogst). Er is gekozen voor wintergerst, omdat dit gewas qua bodemgezondheid gunstiger is dan wintertarwe. Ook de DVE/RE-verhouding is bij wintergerst gunstiger dan bij wintertarwe. Een deel van de wintergerst 
wordt gebruikt voor veevoerdoeleinden (dat deel dat de maïs van de melkveehouder in de samenwerking vervangt) en een deel voor humane doeleinden.

\section{Groenbemesters}

- $\quad$ Na maïs wordt op het akkerbouwbedrijf Japanse haver ingezaaid als verplicht vanggewas. Op het melkveebedrijf wordt in het wisselbouwsysteem na de maïs altijd het nieuwe gras ingezaaid. Laatstgenoemde heeft dan de functie van vanggewas.

- Bij de variant waarbij op het akkerbouwbedrijf snijmaïs is vervangen door wintergerst (ZON-7), wordt na de wintergerst Japanse haver ingezaaid.

\subsection{Centraal-Nederland (CEN)}

\section{Referentie}

Voor deze regio is er voor gekozen om de situatie in de Noordoostpolder als uitgangspunten te nemen, omdat hier sprake is van een intensieve samenwerking tussen melkveehouderij- en akkerbouwbedrijven.

Uitgangspunt is een melkveebedrijf met derogatie ( $80 \%$ gras en $20 \%$ maïs) en een akkerbouwbedrijf met 1:3 pootaardappelen (referentie, uitgangssituatie). Voor de melkveehouderij is samenwerking gebruikelijk. Er is gekozen voor een referentievariant waarbij er sprake is van grondruil met een akkerbouwer en een bloembolteler (CEN-1). Op het melkveebedrijf worden pootaardappelen en tulp geteeld in ruil voor gras op het akkerbouw- en bloembolbedrijf. In dit project kijken we alleen naar de grondruilsituatie met het akkerbouwbedrijf. In tegenstelling tot de zandregio's is hier gekozen voor uitruil van gras en akkerbouwgewas i.p.v. uitruil met maïs. Dit is gedaan, omdat uitruil met gras gebruikelijker is dan met maïs. Akkerbouwers hebben liever geen maïs vanwege risico's voor bodemstructuur vanwege de relatief late oogst.

De akkerbouwer handhaaft na het aangaan van de samenwerking de 1:3 teeltfrequentie op zijn eigen bedrijf en gaat dus extra pootaardappelen telen. Hierbij moet worden opgemerkt dat er wel een markt moet zijn voor de extra geproduceerde aardappelen.

Omdat er veel meer akkerbouw dan melkveehouderij in deze regio is, is voor de akkerbouw ook een referentie zonder samenwerking meegenomen (voor een aantal eiwitvarianten, zie hieronder).

\section{Varianten}

\section{Gezamenlijk grondgebruik}

- $\quad$ Meer blijvend grasland (CEN-2)

Dat is hier vormgegeven door een uitruil met maïs i.p.v. gras. Hierdoor is er meer ruimte voor blijvend grasland. Deze variant geeft ook inzicht in de verschillen tussen uitruil van gras of maïs bij gezamenlijke grondruil voor de bodemvruchtbaarheid op het akkerbouw- en melkveebedrijf.

\section{Meer eiwitteelt}

- $\quad$ Op het melkveebedrijf is een variant meegenomen waarbij het gras in het wisselbouwsysteem is vervangen door gras-rode klaver (CEN-3).

- Op het akkerbouwbedrijf is gekeken naar het effect van vervanging van graan door zaadleguminosen. Alle relevante peulvruchtgewassen worden naast elkaar gezet: erwten (CEN-4), veldbonen (CEN-5) en soja (CEN-6). Hierdoor vindt een directe vergelijking plaats. Dit is gedaan voor een situatie zonder samenwerking.

\section{Groenbemesters}

- Op het akkerbouwbedrijf wordt na wintertarwe, erwten en veldbonen bladrammenas gezaaid.

- Op het melkveebedrijf worden geen groenbemesters gezaaid, omdat na vroeg geoogste bouwlandgewassen het nieuwe grasland wordt ingezaaid. 


\section{$5.4 \quad$ Zuidwest-Nederland (ZWN)}

\section{Referentie}

Uitgangspunt is een melkveebedrijf met derogatie ( $80 \%$ gras en $20 \%$ maïs) en een akkerbouwbedrijf met $1: 4$ consumptieaardappelen (refentie, uitgangssituatie). De samenwerkingen die in deze regio plaatsvinden, betreffen meestal de uitruil van aardappelen en maïs (ZWN-1). Hierbij wordt op het melkveebedrijf een deel van de maïs vervangen door consumptieaardappel. Het areaal maïs dat de melkveehouder mist, wordt geteeld op het akkerbouwbedrijf en vervangt een deel van het graan. De akkerbouwer handhaaft na de samenwerking de 1:4 teeltfrequentie op zijn eigen bedrijf en gaat dus extra aardappelen telen. De akkerbouwers in deze regio hebben een voorkeur voor uitruil met maïs, vanwege het risico van ritnaaldenschade bij uitruil met gras.

\section{Varianten}

\section{Gezamenlijk grondgebruik}

- Dit is vormgegeven via: 1) vervanging van snijmaïs door MKS (maïskolvenschroot) op het akkerbouwbedrijf ( $\mathrm{ZWN}-2$ ) en 2) teelt van luzerne op het akkerbouwbedrijf (ZWN-3). In het laatste geval vervangt de luzerne de maïs. De eerste variant is interessant, omdat er bij MKS meer organische stof wordt achtergelaten in vergelijking met de teelt van snijmaïs. Luzerne is interessant, omdat het een vlinderbloemige is (eiwitteelt) die bovendien een goede bodemstructuur achterlaat.

\section{Groenbemesters}

- Op het akkerbouwbedrijf wordt na wintertarwe bladrammenas gezaaid.

- Op het melkveebedrijf worden geen groenbemesters gezaaid vanwege het relatief late oogsttijdstip van de daar geteelde gewassen. 
Tabel 5.2 Bouwplannen akkerbouw en melkveehouderij ${ }^{1}$.

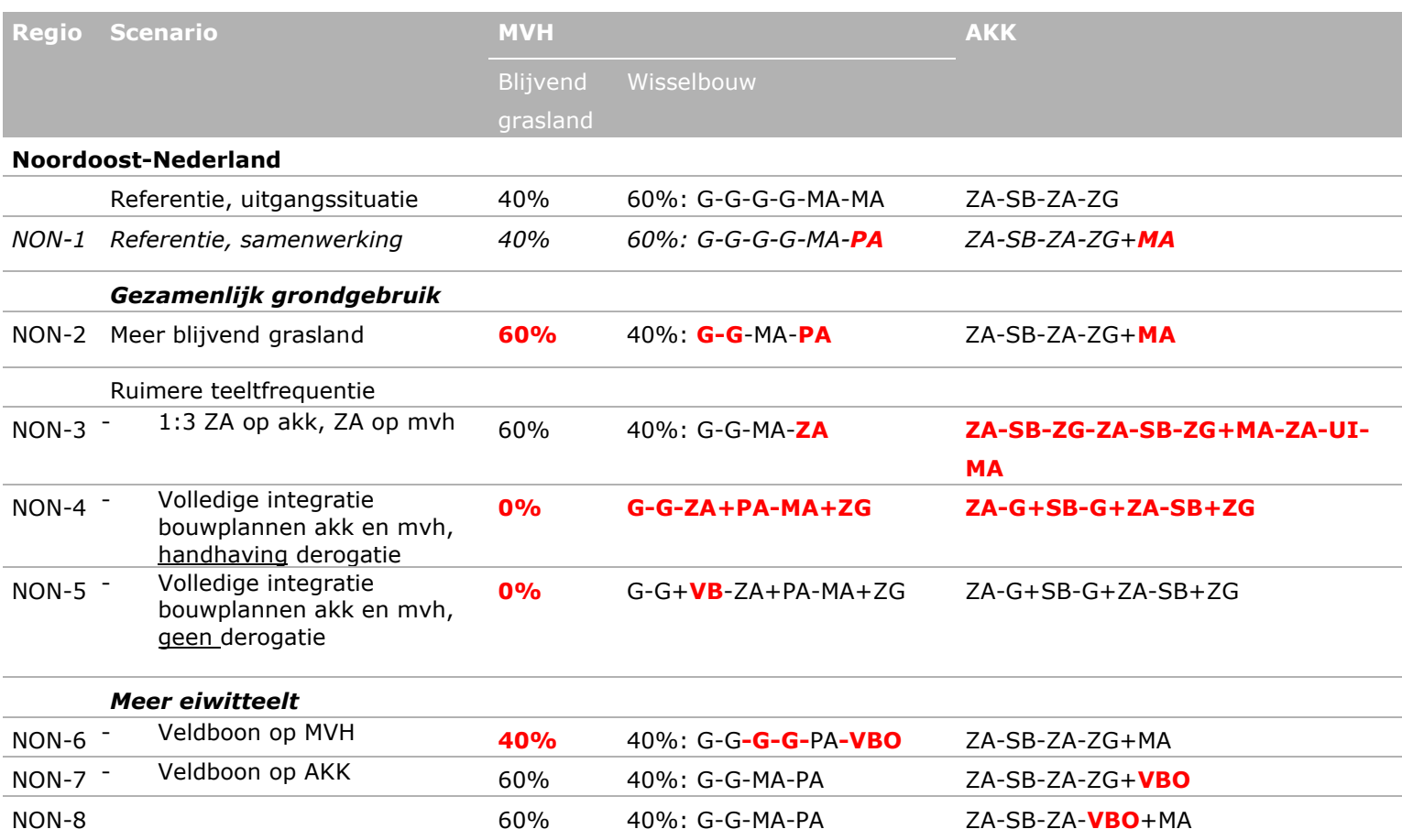

\section{Zuidoost-Nederland}

Referentie, uitgangssituatie

$20 \%$

80\%: G-G-G-MA-G-G-G-MA ER+BO-SB-CA-MA-PE-SB-CA-MA

ZON-1 Referentie, samenwerking

$20 \%$

80\%: G-G-G-MA-G-G-G-CA ER+BO-SB-CA-MA-PE-SB-CA-MA

\section{Gezamenlijk grondgebruik}

\begin{tabular}{|c|c|c|c|c|}
\hline ZON-2 & Meer blijvend grasland & $40 \%$ & 60\%: G-G-G-G-CA-MA & $E R+B O-S B-C A-M A-P E-S B-C A-M A$ \\
\hline ZON-3 & & $50 \%$ & 50\%: G-G-G-CA-MA & $E R+B O-S B-C A-M A-P E-S B-C A-M A$ \\
\hline ZON-4 & & $60 \%$ & 40\%: G-G-CA-MA & $E R+B O-S B-C A-M A-P E-S B-C A-M A$ \\
\hline
\end{tabular}

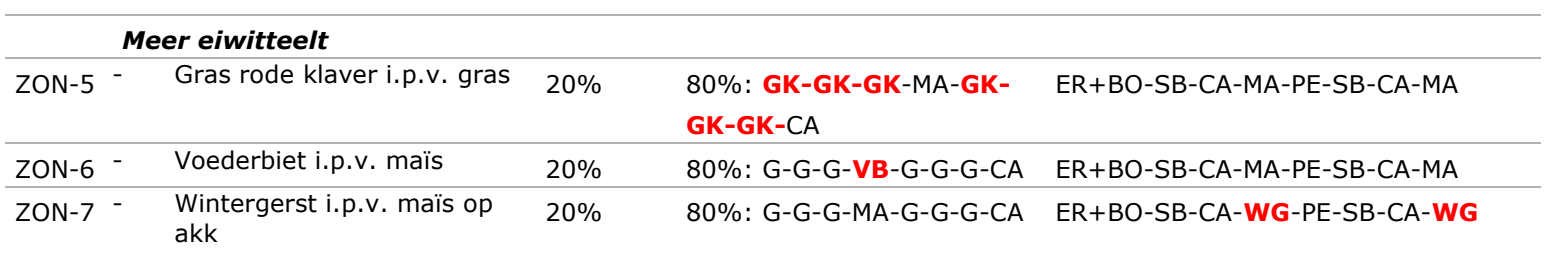

\section{Centraal-Nederland}

\begin{tabular}{lllll}
\hline & Referentie, uitgangssituatie & $20 \%$ & $80 \%: G-G-G-M A-G-G-G-M A$ & PA-SB-UI-PA-WT-PE \\
\hline CEN-1 Referentie, samenwerking & $20 \%$ & $80 \%: G-G-M A-P A-G-G-M A-$ & PA-SB-UI-PA-WT+G-PE \\
& & & TU & (+ G op bollenbedrijf)
\end{tabular}

Gezamenlijk grondgebruik

CEN-2 Meer blijvend grasland $\quad 40 \% \quad 60 \%:$ G-G-PA-G-G-TU PA-SB-UI-PA-WT+MA-PE

(+ MA op bollenbedrijf)

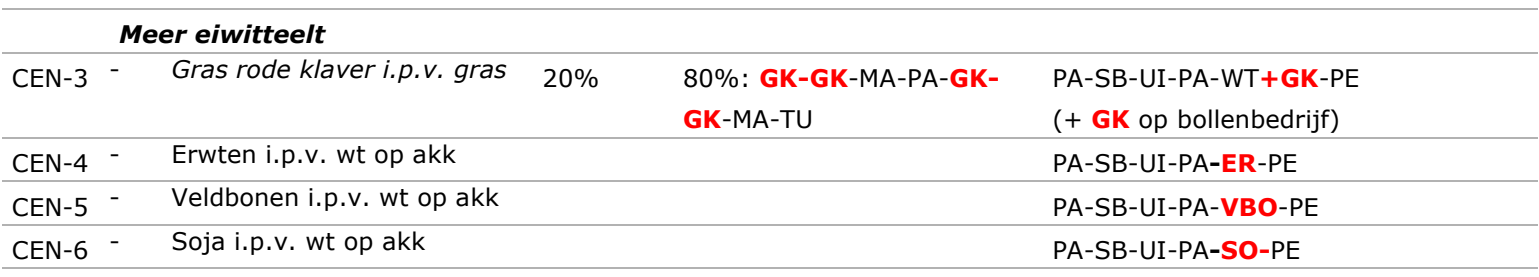




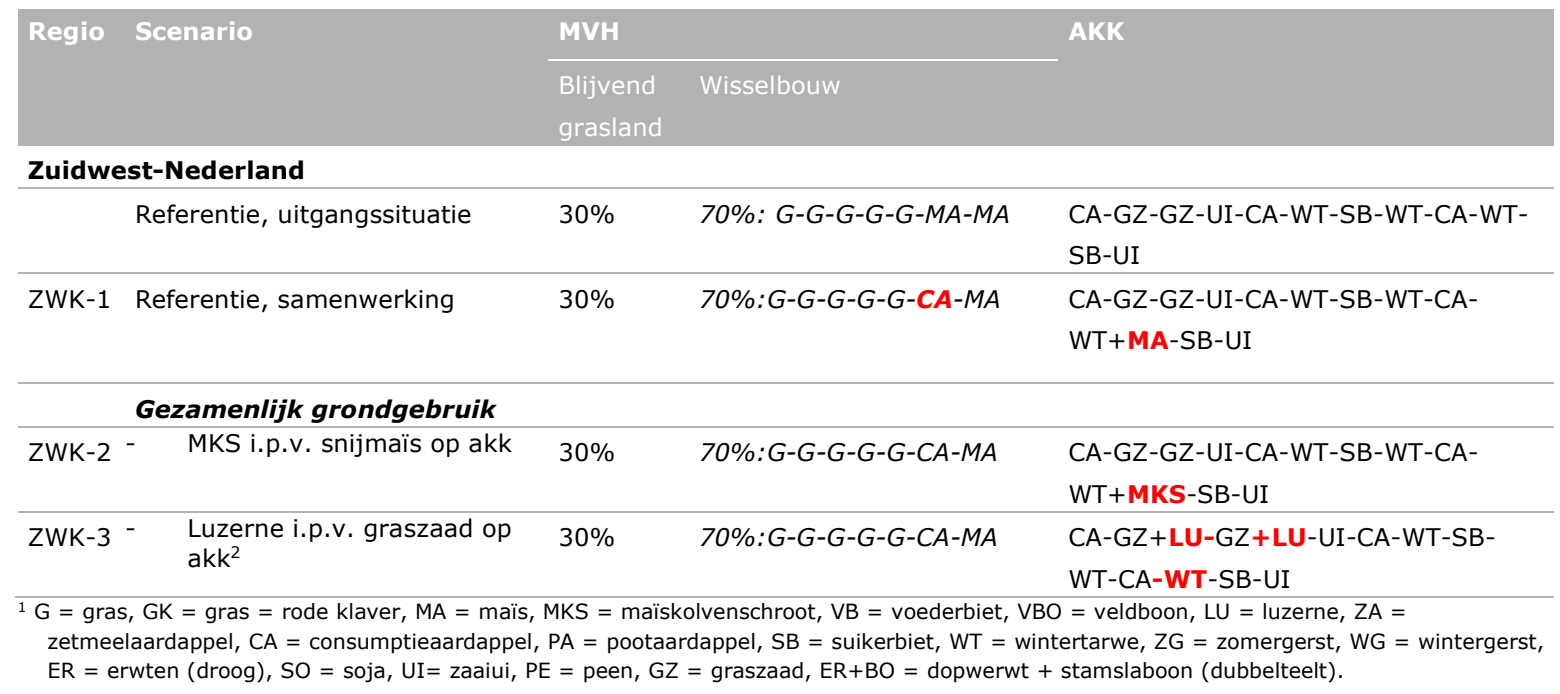




\section{$6 \quad$ Uitgangspunten berekeningen en beoordeling bouwplannen}

\subsection{Uitgangspunten berekeningen}

De bouwplannen worden beoordeeld op een aantal kengetallen. In deze paragraaf wordt beschreven hoe deze kengetallen worden berekend en wat de onderliggende uitgangspunten zijn. Eerst wordt ingegaan op de uitgangspunten die gelden voor beide bedrijfstypen (melkveehouderij en akkerbouw) en vervolgens wordt ingegaan op specifieke uitgangspunten voor de beide bedrijfstypen.

\subsubsection{Algemeen}

\section{Bedrijfsareaal}

De in deze studie gebruikte bedrijfs- en gewasarealen voor zowel het melkveehouderijbedrijf als het akkerbouwbedrijf in de 4 regio's zijn afgeleid van de gegevens van het CBS en het BIN. Voor het melkveehouderijbedrijf is uitgegaan van gespecialiseerde melkveehouderijbedrijven. Omdat uit de CBS gegevens bleek dat de gemiddelde oppervlakte van zowel de akkerbouwbedrijven als de melkveehouderijbedrijven van dezelfde ordegrootte waren, zijn deze in deze studie aan elkaar gelijk gesteld:

- Noordoost-Nederland: 65 ha

- Zuidoost-Nederland: 45 ha

- Centraal-Nederland: 55 ha

- Zuidwest-Nederland: 55 ha

\section{Economisch bouwplan en perceelbouwplan}

In de varianten waar er sprake is van gezamenlijk grondgebruik tussen melkveehouderij en akkerbouw zijn de bouwplannen zoals ze op naam van het melkveehouderijbedrijf en het akkerbouwbedrijf staan afwijkend van de feitelijke situatie op de grond van de beide bedrijven. Op de grond van de akkerbouwer worden immers veehouderijgewassen geteeld en op de grond van de melkveehouder akkerbouwgewassen. Om dit te ondervangen werken we in deze studie met twee bouwplannen: het economisch bouwplan en het perceelsbouwplan (zie als voorbeeld Figuur 6.1). Het economisch bouwplan bestaat uit de gewassen die op naam van het bedrijf staan en is van belang voor o.a. de economische effecten en de broeikasgasemissies. Het perceelsbouwplan bestaat uit de gewassen die werkelijk op de grond van het bedrijf worden geteeld. Het laatste is vooral van belang voor de beoordeling van de bodemvruchtbaarheidsaspecten zoals bodemgezondheid en de organische stofaanvoer.

Daarnaast is gesteld dat de totale bedrijfsoppervlakte van het melkveehouderijbedrijf nodig is voor de productie van voer voor het aanwezige vee. Dat houdt expliciet in dat samenwerking met akkerbouwbedrijven leidt tot grondruil en niet tot verhuur van land. In enkele bouwplannen is er grondruil tussen één melkveehouderij bedrijf en twee akkerbouwbedrijven waarvan er één is gedefinieerd als "bollenbedrijf" (Tabel 5.2). Het bollenbedrijf wordt in deze studie buiten beschouwing gelaten. 




Figuur 6.1 Economisch- en percelen bouwplan melkveehouderijbedrijf referentie met gewassen in percentage van de bedrijfsoppervlakte.

\section{Gebruik van dierlijke mest en kunstmest}

\section{Dierlijke mest}

Bij samenwerking gebruikt de melkveehouder de eigen mest tot aan de plaatsingsruimte op het bedrijf. De overige mest (overschotsmest) gaat naar het akkerbouwbedrijf. Op het akkerbouwbedrijf wordt verder aangevuld met varkensdrijfmest. Op zandgrond wordt aangevuld tot de fosfaatnorm (er wordt geen kunstmestfosfaat gebruikt), op kleigrond tot $80 \%$ van de fosfaatruimte.

\section{Kunstmest}

Bij het stikstofkunstmestgebruik is ervan uitgegaan dat de gebruiksruimte voor werkzame $\mathrm{N}$ na aftrek van de werkzame $\mathrm{N}$ uit dierlijke mest volledig wordt gebruikt.

Op de melkveebedrijven en op de akkerbouwbedrijven op zand wordt geen fosfaatkunstmest gebruikt. Op de klei-akkerbouwbedrijven wordt de fosfaatgebruiksruimte opgevuld met kunstmestfosfaat.

Voor kali wordt de aanvoer met dierlijke mest aangevuld met kunstmest tot aan het bemestingsadvies. Dit betekent in de meeste gevallen dat de aanvoer gelijk is aan de kaliafvoer met geoogst product, waarbij op zandgrond een onvermijdbaar verlies van $40 \mathrm{~kg} \mathrm{~K}_{2} \mathrm{O}$ per ha wordt gehanteerd (www.handboekbodemenbemesting. $\mathrm{nl}$ ).

\subsubsection{Akkerbouw}

\section{Economie}

De economische effecten zijn beoordeeld via de verandering van het bouwplansaldo. Het bouwplansaldo wordt berekend aan de hand van het gewogen gemiddelde:

$$
\bar{x}=\frac{\sum_{i=1}^{n} w_{i} x_{i}}{\sum_{i=1}^{n} w_{i}}
$$

Hierbij geldt $\bar{x}$ als het gewogen gemiddelde (bouwplansaldo per hectare); $x$ als het individuele gewassaldo; $w$ als de wegingsfactor (aantal hectares); $i$ refereert naar de sommatie-index van een specifiek gewas; $n$ refereert naar het aantal gewassen binnen het bouwplan.

De gewassaldo's zijn afkomstig uit de Kwantitatieve Informatie voor de Akkerbouw en de Vollegrondsgroenteteelt (KWIN AGV) (Van der Voort, 2018). Voor de eiwitgewassen die niet in de KWIN AGV opgenomen zijn of voor gewassen waarbij de lokale condities dusdanig verschillen van die in de KWIN zijn expertinschattingen gebruikt. Voor de eiwitgewassen is gesproken met R. Timmer (pers. comm., 5 augustus 2020) en voor gewassen waarbij de lokale condities afwijken ten opzichte van de uitgangspunten van de KWIN AGV is gesproken met M. Van der Voort (pers. comm., 30 juni 2020). 
Als een variant leidt tot een andere mechanisatiebehoefte wordt dat niet in altijd vertaald in het saldo, omdat in het saldo alleen de toegerekende kosten meegenomen zijn. De kosten van mechanisatie kunnen echter een grote rol spelen bij de haalbaarheid van een alternatief. Daarom worden er in dit onderzoek loonwerktarieven meegenomen.

Het dierlijke mest- en kunstmestgebruik is conform de uitgangspunten zoals hierboven weergegeven en wordt dus gecorrigeerd op de kosten van meststoffen bij saldo's uit de KWIN AGV. Bij samenwerking wordt de rundveemest om niet toegediend door de melkveehouder en bij gebruik van varkensmestproducten gaan we uit van een marktprijs (-€3 per ton, toegediend op het land).

\section{Klimaatrisico's}

Op basis van de methodiek en uitgangspunten van de Klimaat stress test (zie 3.2., 3.3 en Verstand et al., 2020) worden de risico's uitgewerkt voor huidige en toekomstige bouwplannen. Hierbij wordt de toename of afname van het risico van de bouwplanvarianten in vergelijking met het referentiebouwplan in beeld gebracht.

\section{Milieutechnische kengetallen}

De bouwplannen worden met de Nutriëntenbalans Akkerbouw doorgerekend. Deze geeft als output:

- $\quad \mathrm{N}$ - en P-(bodem)overschot

- Ammoniakemissie op het veld (meststoffen, gewassen)

- Broeikasgasemissies

- Aanvoer effectieve organische stof (EOS)

\section{Organische stof}

Voor alle doorgerekende bouwplannen is de aanvoer van effectieve organische stof (EOS) uitgerekend op basis van kengetallen zoals opgenomen in het handboek bodem en bemesting (www.handboekbodemenbemesting.nl). De EOS is de organische stof uit gewasresten en organische mest die een jaar na toediening nog aanwezig is.

\section{Bodemgezondheid}

De bouwplannen op het akkerbouwbedrijf, maar ook het bouwplan in het wisselbouwdeel van het melkveebedrijf, worden beoordeeld op het risico van schadelijke bodempathogenen voor de risicogewassen in het bouwplan (o.a. via Aaltjesschema).

\subsubsection{Melkveehouderij}

\section{Bedrijfsstructuur}

Naast de bedrijfsoppervlakte van het melkveehouderijbedrijf zijn ook het aandeel blijvend grasland, de dieraantallen en de melkproductie gebaseerd op CBS en BIN informatie (Tabel 6.1). Omdat in de referentie ervan uitgegaan is dat de bedrijven gebruik maken van de derogatieregeling is het aandeel grasland op $80 \%$ van de bedrijfsoppervlakte gesteld en het aandeel bouwland op $20 \%$ van de bedrijfsoppervlakte.

In deze studie wordt ervan uitgegaan dat al het grasland op het bedrijf productiegrasland is. 
Tabel 6.1 Gegevens referentiemelkveehouderijbedrijven in de vier regio's.

\begin{tabular}{|c|c|c|c|c|}
\hline & NON & ZON & CEN & ZWN \\
\hline Areaal & 65 & 45 & 55 & 55 \\
\hline Jongvee $<1$ jaar, $\mathrm{n}$ & 36 & 38 & 31 & 36 \\
\hline Jongvee $>1$ jaar, $n$ & 38 & 38 & 30 & 36 \\
\hline $\mathrm{N}$-excretie, kg/ha & 249 & 358 & 291 & 281 \\
\hline $\mathrm{P}_{2} \mathrm{O}_{5}$-excretie, $\mathrm{kg} / \mathrm{ha}$ & 91 & 130 & 106 & 102 \\
\hline $\mathrm{N}$-plaatsingsruimte, $\mathrm{kg} / \mathrm{ha}$ & 250 & 230 & 250 & 250 \\
\hline
\end{tabular}

\section{Beweiding}

In deze studie is ervan uitgegaan dat het aandeel blijvend grasland in de referentie tevens de grootte van de huiskavel is (Tabel 6.2). Indien in de doorgerekende varianten het aandeel blijvend grasland wijzigt, wordt het aandeel weidegang uit de referentie aangehouden. Op basis van het aantal Groot Vee Eenheden (GVE)/ha blijvend grasland en het aandeel van de dieren dat weidegang krijgt uit de CBS statistieken is vastgesteld of er weidegang op het bedrijf plaatsvindt. Op basis van expertkennis is het beweidingssysteem gekozen. Indien er weidegang plaatsvindt, is er sprake van gecombineerd graslandgebruik (op een perceel grasland wordt een aantal sneden geweid en een aantal sneden gemaaid). Wanneer er geen weidegang plaatsvindt, worden alle sneden gemaaid.

Tabel 6.2 Landgebruik melkveehouderijbedrijven.

\begin{tabular}{|c|c|c|c|c|c|c|c|c|c|c|}
\hline 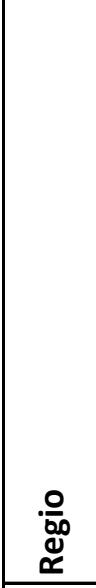 & 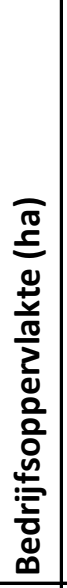 & 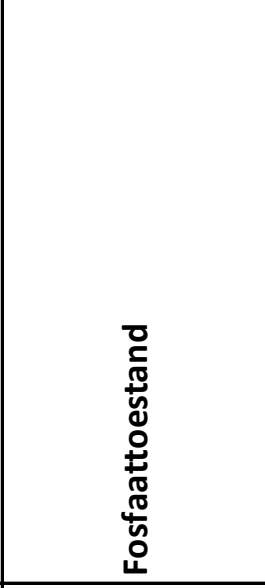 & $\begin{array}{l}\frac{t}{0} \\
0 \\
0 \\
0 \\
0 \\
0 \\
0\end{array}$ & 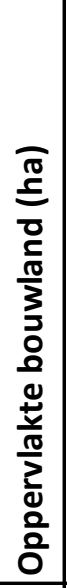 & 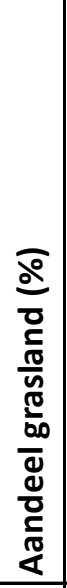 & 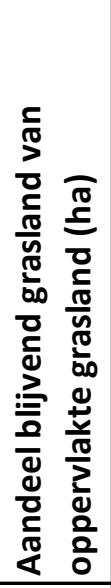 & 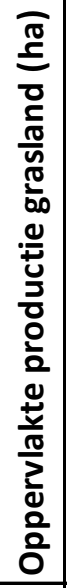 & 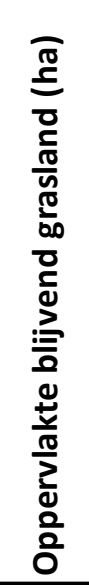 & $\begin{array}{l}\text { 荡 } \\
\frac{0}{0} \\
\frac{0}{0} \\
\frac{0}{0} \\
\frac{\pi}{4} \\
\frac{0}{0}\end{array}$ & 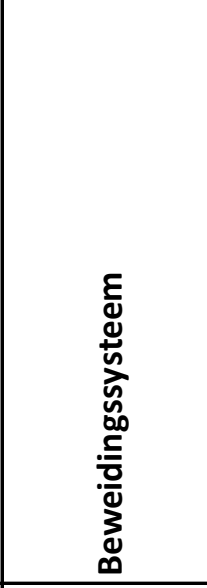 \\
\hline NON & 65 & Ruim voldoende & Zand & 13 & 80 & 40 & 52 & 26 & Gecombineerd gebruik & Omweiden \\
\hline CEN & 55 & Neutraal & Klei & 11 & 80 & 20 & 44 & 11 & Alleen maaien & Geen \\
\hline ZWN & 55 & Neutraal & Klei & 11 & 80 & 30 & 44 & 16.5 & Gecombineerd gebruik & Standweiden \\
\hline ZON & 45 & Ruim voldoende & Zand & 9 & 80 & 20 & 36 & 9 & Alleen maaien & Geen \\
\hline
\end{tabular}

\section{Gewasopbrengsten}

Voor de verschillende varianten wordt de voederwaardeopbrengst van het bouwplan uitgerekend. Dit wordt gedaan op basis van de gewasopbrengsten, uitgedrukt in hoeveelheid droge stof, en de voederwaarde van de gewassen; Voedereenheid Melk (VEM), Ruw eiwit (RE), Darm Verteerbaar Eiwit (DVE), de Onbestendig Eiwit Balans (OEB) en de Verzadigings Waarde (VW)). Het beweidingssysteem 
in combinatie met het graslandgebruik is bepalend voor de opbrengst van het grasland. In deze studie is de opbrengst voor tijdelijk en blijvend grasland aan elkaar gelijk gesteld. Vooraf is gesteld dat tweederde van de jaaropbrengst van het gras wordt geoogst als kuilgras en één-derde als weidegras.

In deze studie is er geen onderscheid gemaakt tussen ultra vroege maïs en standaard maïs. Er is gerekend met de opbrengst van standaard maïs. Voor de opbrengst- en kwaliteit van de overige voedergewassen wordt uitgegaan van de informatie verzameld in PPS Ruwvoer en Bodem (Van Dijk et al., 2020).

Om de potentie van het geteelde voer voor de productie van melk inzichtelijk te maken, is de VEM/DVE verhouding per VW eenheid van de geteelde droge stof berekend. Om de waarde van dit kengetal van de geteelde droge stof te kunnen positioneren, is het kengetal ook berekend voor de gevoerde droge stof (aangekocht en eigen ruwvoer, eigen en aangekocht krachtvoer). Hierbij dient in ogenschouw genomen te worden dat de gevoerde droge stof niet het optimale rantsoen is, maar de resultante van een optimalisatie van de huidige situatie (aanwezige voedermiddelen en de verhouding waarin ze aanwezig zijn in de specifieke variant).

\section{Mestproductie en plaatsingsruimte}

Op basis van het aantal dieren (melkvee en jongvee) op het bedrijf en de forfaitaire excretienormen voor fosfaat en stikstof (www.rvo.nl) zijn de fosfaat- en stikstofproductie op het bedrijf berekend. De plaatsingsruimte voor stikstof uit dierlijke mest en fosfaat is bepaald op basis van het areaal gras en bouwland en de gebruiksnormen (www.rvo.nl). Vervolgens is het mest- $\mathrm{N}$ - en $\mathrm{P}_{2} \mathrm{O}_{5}$-overschot op het bedrijf berekend, zijnde het verschil tussen de fosfaat- en stikstofproductie op het bedrijf enerzijds, en de fosfaat- en stikstofgebruiksruimte anderzijds.

In de varianten waar er sprake is van grondruil tussen het akkerbouwbedrijf en het melkveehouderijbedrijf zijn de fosfaat- en stikstofgebruiksruimte berekend op basis van de gewassen zoals die op naam van het melkveehouderijbedrijf staan (economisch bouwplan).

\section{Voeropname en voerverbruik door de veestapel}

Voor de verschillende varianten wordt - op basis van de ruwvoerproductie, hoeveelheid en samenstelling, de beoogde melkproductie en de aanwezige veestapel - de benodigde hoeveelheid mengvoer berekend. Hierbij is het uitgangspunt dat de veestapel en het melkproductie niveau gehandhaafd blijven. Voor alle rantsoenen is de OEB balans voldoende.

\section{Toewijzing voervoorraden aan het jongvee}

In alle scenario's met en zonder weidegang is uitgegaan van een perfect gespreid afkalfpatroon. Dit betekent voor de berekening dat de dagelijks energiebehoefte uitgedrukt in VEM en de voeropnamecapaciteit van de melkveestapel constant is.

Om de berekeningen te vereenvoudigen, is er bij alle scenario's van uitgegaan dat het ruwvoer voor het jongvee bij scenario's zonder weidegang alleen bestaat uit graskuil en bij scenario's met weidegang uit graskuil en weidegang. Voor alle scenario's is er tevens van uitgegaan dat het jongvee jonger dan 1 jaar (jongvee $<1 \mathrm{j}$ ) niet wordt geweid en alleen op stal wordt gehouden met graskuil en krachtvoer. Voor het jongvee in een leeftijd tussen 1 en 2 jaar (jongvee 1-2j) en jongvee ouder dan 2 jaar (jongvee $>2 \mathrm{j}$ ) is uitgegaan van onbeperkte beweiding gedurende 180 dagen per jaar.

Op basis van de bovenstaande aannames is voor alle scenario's eerst de voeropname van het jongvee met het PR-jongveemodel berekend (Mandersloot, 1989). Vervolgens zijn de berekende opgenomen hoeveelheden graskuil en weidegras afgetrokken van de totale geproduceerde hoeveelheden beschikbare graskuil en weidegras. De resterende hoeveelheden voer zijn beschikbaar voor de melkkoeien. 
Uit een eerste berekening bleek dat bij scenario's ZWK-1, ZWK-3 en ZWK-4 de berekende opname van weidegras door het jongvee groter was dan de berekende voorraad. Daarom is voor deze scenario's besloten dat er geen weidegang werd toegepast voor jongvee $1-2 \mathrm{j}$.

\section{Toewijzing voervoorraden aan het melkvee}

$\mathrm{Na}$ het berekenen van de ruwvoeropname door het jongvee, is de resterende voervoorraad toegewezen aan het melkvee. Bij de toewijzing is volgende werkwijze toegepast. Alle verse producten (weidegras, voederbieten), zelf geteeld krachtvoer en krachtvoervervangers (gerst, veldbonen, MKS) worden volledig verbruikt.

Vervolgens wordt een rantsoenoptimalisatie uitgevoerd waarbij de opname uit het eigen ruwvoer is gemaximaliseerd en de opname van krachtvoergift wordt geminimaliseerd binnen de randvoorwaarde van de melkproductiedoelstelling. De verzadigingswaarde is de beperkende factor voor opname en VEM-opname is de beperkende factor voor melkproductie (Zom, 2014). Hieruit volgt dat voeders met een hoge VEM/verzadigingswaarde met voorrang in het rantsoen komen. Dit betekent tevens dat verhouding tussen verschillende voeders in het rantsoen niet per se hetzelfde is als in voorraden.

In geval van een berekend ruwvoeroverschot, d.w.z. de totale opname aan ruwvoer is kleiner dan de voorraad beschikbaar ruwvoer, bestaat het ruwvoeroverschot uit de het ruwvoer met de laagste VEM/verzadigingswaarde-verhouding. In geval van een ruwvoertekort, werd altijd aangenomen dat het tekort met snijmaïs werd aangevuld.

Om de gewenste melkproductie te realiseren, wordt het rantsoen aangevuld met mengvoer met een VEM-waarde van 1085 VEM/kg DS. Dit komt overeen met krachtvoer met ca. 940-960 VEM per kg, bij een drogestof gehalte tussen 87 en $90 \%$. De maximale krachtvoergift per dag was $14.5 \mathrm{~kg}$, deze limiet is gebaseerd op de maximale krachtvoer gift in de dataset die is gebruikt voor de ontwikkeling van het Koemodel (Zom et al., 2012b, a).

Per scenario is met het Koemodel de totale voeropname en melkproductie berekend gedurende de lactatieperiode van 365 dagen en de droogstand. Er is uitgegaan van een tussenkalftijd van tijd 420 dagen en 55 dagen droogstand. De voeropname is teruggerekend naar dag basis en vermenigvuldigd met 365 op de voeropname per kalender jaar te berekenen.

Op basis van het DVE/OEB systeem werd op dier/dag basis een DVE behoefte berekend (CVB, 2016). De dagelijkse DVE-behoefte gedeeld door de berekend dagelijkse krachtvoergift resulteerde in een gewenst minimaal DVE-gehalte per kg krachtvoer.

\section{Economie}

Er wordt alleen gekeken naar bedrijfsaspecten die veranderen t.o.v. de referentie. De meeste scenario's hebben betrekking op vervanging van een bestaand gewas door een ander en verandering van de verhouding blijvend en tijdelijk grasland. Dat heeft gevolgen voor:

- Teelt- en bewaarkosten. Bij vervanging van gewassen wordt er gebruik gemaakt van de kosten van de vervangende teelt t.o.v. huidige teelt (op basis van KWIN Veehouderij).

- Inzaaikosten gras. Deze veranderen bij verschuiving van de verhouding blijvend en tijdelijk gras (inrekenen volgens KWIN veehouderij).

- Kosten krachtvoer. Bij een verandering van bouwplan verandert de voederwaardeproductie, waardoor ook de behoefte aan krachtvoer verandert.

- Melkproductie. Insteek is om bij een veranderde voederwaardeproductie eerst de krachtvoergift zo aan te passen dat de melkproductie gelijk blijft. Als dat niet lukt, zal de verandering in melkproductie worden aangegeven.

\section{Klimaatrisico's}

Op basis van de methodiek en uitgangspunten van de Klimaat stress test (Verstand et al., 2020) worden de risico's uitgewerkt voor huidige en toekomstige bouwplannen. Hierbij wordt de toename of afname van het risico in beeld gebracht van de bouwplanvarianten t.o.v. het referentiebouwplan. De 
risico-inschatting beperkt zich tot de teeltrisico's van ruwvoer en/of krachtvoerproductie. De klimaatrisico's voor de dieren (zoals hittestress) worden niet berekend in deze studie.

\section{Milieutechnische kengetallen}

Ook hier wordt gekeken naar de verandering t.o.v. de referentie. De volgende kengetallen worden meegenomen:

- NP-overschotten

- Ammoniakemissie

- Broeikasgasemissies

\section{Berekening TAN excretie en methaan emissie}

De totale ammoniakale stikstof excretie (TAN excretie) en methaan emissies zijn berekend volgens de systematiek van de KringloopWijzer (Dijk et al., 2020).

De stikstofexcretie is berekend als de N-opname minus de vastlegging van stikstof in melk, groei, dracht te berekenen. De stikstof opname minus de verteerbare stikstofopname is de fecale stikstof uitscheiding. De verteerbare stikstof opname minus de $\mathrm{N}$ vastlegging is de TAN excretie.

De verteerbare $\mathrm{N}$ opname uit ruwvoeders is afgeleid van de CVB veevoedertabel (CVB, 2018). De verteerbare $\mathrm{N}$ opname uit krachtvoer is geschat op basis van de berekende DVE-gehalten in het krachtvoer en de gegevens van het ruw eiwit gehalte en stikstof verteerbaarheid per DVE-klasse zoals vastgesteld door Bikker et al. (2011).

De methaan-emissie is berekend op basis van de formules voor methaan-emissie factoren (EF) en de tabelwaarden van de KringloopWijzer (Van Dijk et al., 2020).

\section{Organische stof}

Voor alle doorgerekende bouwplannen is de aanvoer van effectieve organische stof (EOS) uitgerekend op basis van kengetallen zoals opgenomen in het handboek bodem en bemesting (www.handboekbodemenbemesting.nl). De EOS is de organische stof uit gewasresten en organische mest die een jaar na toediening nog aanwezig is.

\subsubsection{Systeemeffecten}

\section{Organische stofaanvoer en koolstofopslag in de bodem}

Op basis van de kengetallen voor de aanvoer van effectieve organische stof (gewasresten, organische mest; www.handboekbodemenbemesting. $\mathrm{nl}$ ) wordt uitgerekend hoeveel effectieve organische stof wordt aangevoerd in de verschillende bouwplanvarianten.

Aanvullend zal een schematische verkenning worden gedaan naar de effecten van verandering van het bouwplan op de koolstofopslag op systeemniveau. Hierbij speelt met name de verhouding blijvend en tijdelijk grasland een rol. Het voorstel is om voor een fictieve bedrijfssituatie (akkerbouw- en melkveebedrijf) een aantal scenario's te bekijken die bij een gelijk bouwplan (aandeel gras, maïs en akkerbouw overal gelijk) verschillen in aandeel blijvend en tijdelijk grasland, variërend van $100 \%$ blijvend grasland tot $100 \%$ tijdelijk grasland. 
62 | Rapport WPR-1062 


\section{$7 \quad$ Resultaten bouwplanberekeningen}

Dit hoofdstuk beschrijft voor de vier regio's, Noordoost-Nederland (Hoofdstuk 7.1), ZuidoostNederland (Hoofdstuk 7.2), Centraal-Nederland (Hoofdstuk 7.3) en Zuidwest-Nederland (Hoofdstuk 7.4), de resultaten van de bouwplan berekeningen. Achtereenvolgens worden, voor zowel het akkerbouw- als melkveehouderijbedrijf beschreven, economie, nutriënten en organische stof, broeikasgasemissies en bodemgezondheid.

\subsection{Noordoost-Nederland}

\subsubsection{Economie}

\subsubsection{Melkveehouderij}

\section{Voederwaarde opbrengst}

In deze studie is ervan uitgegaan dat de opbrengst van tijdelijk en blijvend grasland gelijk is. Hierdoor is de voederwaardeopbrengst in de scenario's NON-1, NON-2, NON-3, NON-4 en NON-8 gelijk omdat deze scenario's alleen verschillen in het areaal tijdelijk en blijvend grasland (Figuur 7.1) niet in de totale oppervlakte grasland. De opbrengsten voor droge stof, kVEM, RE en DVE zijn respectievelijk 695 ton droge stof, 651311 kVEM, 94113 kg RE en 42196 kg DVE.

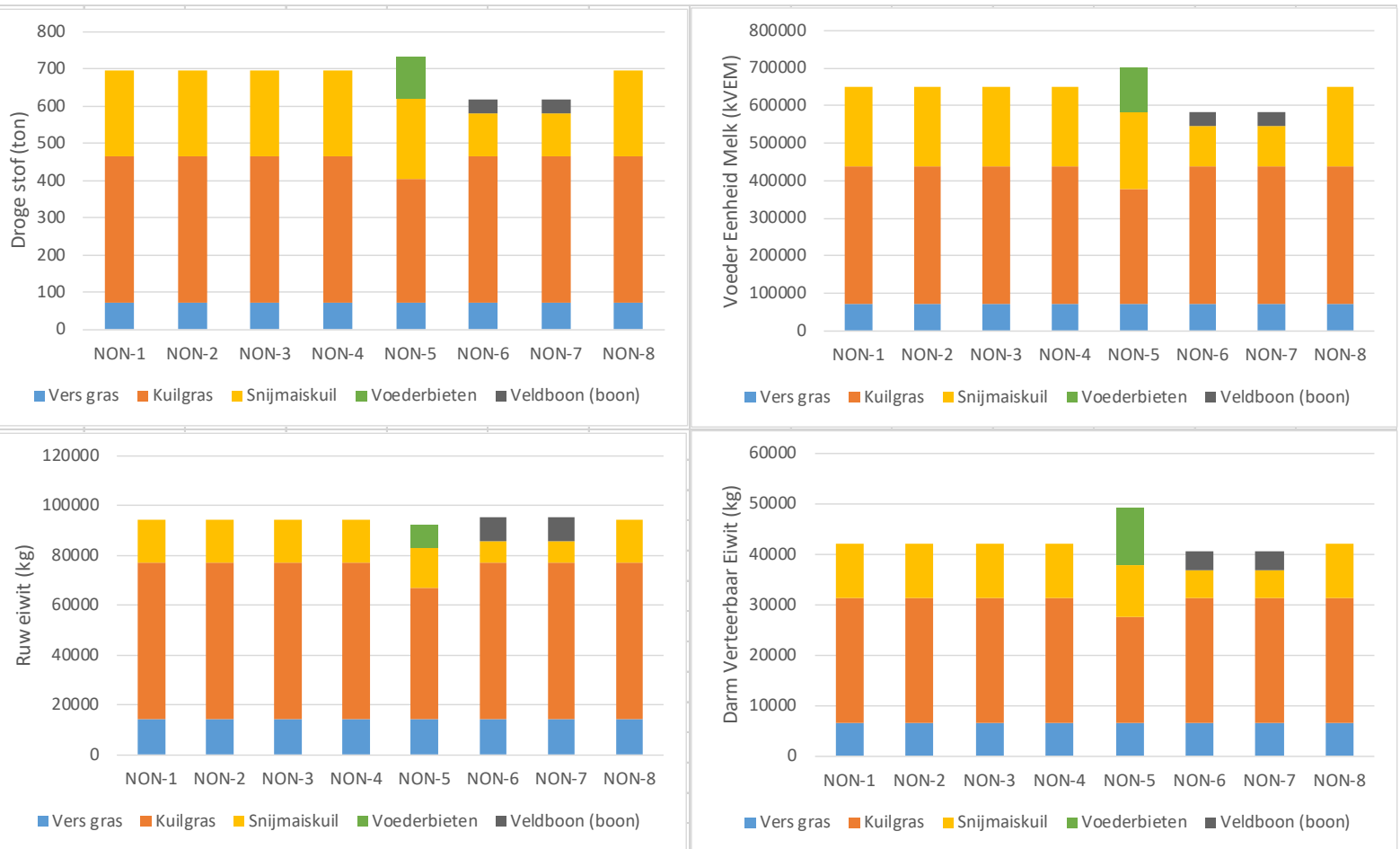

Figuur 7.1 Droge stof, kVEM, ruw eiwit en DVE opbrengst voedergewassen die op naam van het melkveehouderij bedrijf worden verbouwd in de scenario's NON-1 t/m NON-8.

Door het vervangen van 5 ha gras door voederbieten (NON-5) daalt de RE opbrengst van 94113 naar $92079 \mathrm{~kg}$, maar nemen de droge stofopbrengst, kVEM opbrengst en de DVE opbrengst toe naar respectievelijk 733 ton droge stof, 701129 kVEM en 49052 kg DVE (Figuur 7.1). 
Wanneer de helft van het snijmaïs areaal wordt vervangen door veldboon (NON-6 en NON-7) zijn de droge stofopbrengst (616 ton), DVE opbrengst (40644 kg DVE) en kVEM opbrengst (581119 kVEM) lager t.o.v. de referentie. Echter de RE opbrengst $(95400 \mathrm{~kg}$ ) is hoger t.o.v. de referentie (Figuur 7.1).

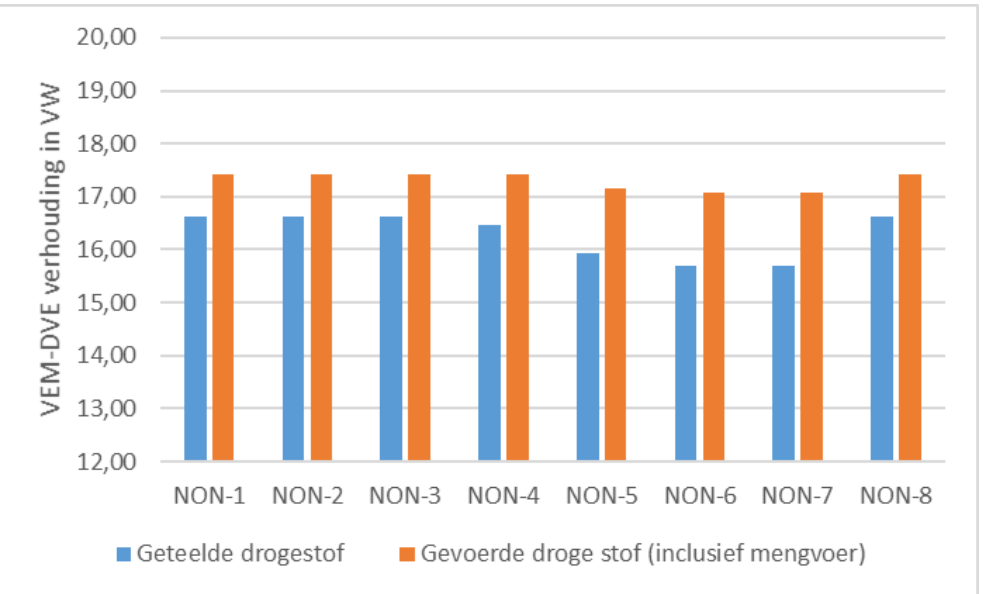

Figuur 7.2 VEM/DVE verhouding per eenheid verzadigingswaarde in de scenario's NON-1 t/m NON-8.

Een maat voor de hoeveelheid melk die een koe kan geven uit de beschikbare droge stof is de VEMDVE verhouding per eenheid VW. Figuur 7.2 laat de VEM-DVE verhouding per eenheid VW voor de geteelde droge stof en de gevoerde droge stof zien. In de scenario's waarin gras en maïs worden geteeld (NON-1, NON-2, NON-3, NON-4 en NON-8), ligt de VEM/DVE verhouding in de VW van de geteelde droge stof het dichtst bij de VEM-DVE in de VW van de gevoerde droge stof (Figuur 7.2).

In de scenario's (NON-6 en NON-7) waar de helft van de snijmaïs (energierijk gewas) wordt vervangen door veldboon (eiwitrijk gewas) is het verschil tussen de geteelde en gevoerde droge stof het grootst.

Wanneer 5 ha gras wordt vervangen door voederbiet (NON-5) is de VEM-DVE verhouding per VW voor zowel de geteelde als de gevoerde droge stof lager. En is het verschil tussen beiden iets groter t.o.v. de referentie (NON-1).

Bijlage 6 geeft voor de scenario's de samenstelling van het gevoerde rantsoen.

\section{Melkproductie}

Voor alle scenario's (NON-1 t/m NON-8) was het mogelijk om het niveau van de melkproductie, 9100 $\mathrm{kg} / \mathrm{melk} / \mathrm{koe} / \mathrm{jaar}$, te halen met het aantal dieren (jongvee en melkkoeien) zoals geformuleerd bij de bedrijfsopzet (Bijlage 8-Tabel 6.1). Hierdoor zijn de inkomsten uit melkgeld nagenoeg gelijk voor alle scenario's (Tabel 7.1).

\section{Aan- en verkoop voer}

Tabel 7.1 laat zien dat er voor NON-1 $€ 12.805$,- voer verkocht is. Dit betreft het overschot aan kuilgras dat op deze wijze in de studie op waarde is gezet. Anderzijds wordt er €68.663,- aan voedermiddelen aangekocht. Dit betreft de aankoop van mengvoer.

Voor de scenario's waar het gras en maïsaandeel in het bouwplan hetzelfde blijven als in NON-1 (NON-2, NON-3, NON-4 en NON 8) verandert de aan- en verkoop van voedermiddelen niet.

Door het vervangen van 5 ha gras door voederbieten (NON-5) dalen de inkomsten uit de voerverkoop met $€ 6.052,-$, omdat het overschot aan kuilgras kleiner is. Anderzijds hoeft er $€ 16.551,-$ minder uitgegeven te worden met de aankoop van mengvoer (Tabel 7.1). 
In de scenario's waar de helft van het areaal snijmaïs wordt vervangen door veldboon (NON-6 en NON-7) wordt al het kuilgras vervoederd (inkomsten uit voerverkoop is $€ 12.804$,- lager t.o.v. de referentie) en is het nodig iets meer mengvoer aan te kopen (aankoop voedermiddelen is $€ 3.115$,hoger).

Bijlage 7 geeft een overzicht van de hoeveelheden droge stof die met welke producten zijn aangekocht en verkocht.

Tabel 7.1 Opbrengsten en kosten voor het referentie bedrijf en de veranderingen ten opzichte van de referentie voor de andere scenario's in $€ /$ bedrijf.

\begin{tabular}{|c|c|c|c|c|c|c|c|c|}
\hline \multirow[t]{2}{*}{ Post / Regio } & \multirow{2}{*}{$\begin{array}{l}\text { Kosten } \\
\text { NON-1 }\end{array}$} & \multicolumn{2}{|c|}{$\Delta$ kosten t.o.v. NON-1 } & \multirow[b]{2}{*}{ NON-4 } & \multirow[b]{2}{*}{ NON-5 } & \multirow[b]{2}{*}{ NON-6 } & \multirow[b]{2}{*}{ NON-7 } & \multirow[b]{2}{*}{ NON-8 } \\
\hline & & NON-2 & NON-3 & & & & & \\
\hline Inkomsten uit melkgeld & 365240 & 0 & 0 & 0 & -240 & -1240 & -1240 & 0 \\
\hline Inkomsten uit voerverkoop & 12805 & 0 & 0 & 0 & -6052 & -12804 & -12804 & 0 \\
\hline Opbrengst totaal & 378046 & 0 & 0 & 0 & -6292 & -14044 & -14044 & 0 \\
\hline Aankoop voedermiddelen & 68663 & 0 & 0 & 0 & -16551 & 3115 & 3115 & 0 \\
\hline Herinzaai tijdelijk en blijvend grasland & 6625 & 946 & 946 & 12303 & 9937 & 0 & 946 & 946 \\
\hline Teelt gras & 40794 & 0 & 0 & 0 & -6523 & 0 & 0 & 0 \\
\hline Teelt maïs ${ }^{1}$ & 15054 & 0 & 0 & 0 & 0 & -7527 & -7527 & 0 \\
\hline Teelt voederbieten & 0 & 0 & 0 & 0 & 10954 & 0 & 0 & 0 \\
\hline Teelt van veldboon ${ }^{2}$ & 0 & 0 & 0 & 0 & 0 & 9931 & 9931 & 0 \\
\hline Teelt vanggewas & 1846 & 0 & 0 & -1846 & -1846 & -923 & -923 & 0 \\
\hline Meststoffen & 7652 & 0 & 0 & 406 & 5392 & -449 & -854 & 0 \\
\hline Toediening meststoffen ${ }^{3}$ & 14748 & 0 & 0 & 0 & -1169 & 698 & 698 & 0 \\
\hline Opslag en bewaring ruwvoer ${ }^{4}$ & 12937 & 0 & 0 & 0 & 1222 & -1712 & -1712 & 0 \\
\hline Kosten totaal & 168319 & 946 & 946 & 10863 & 1417 & 3133 & 3674 & 946 \\
\hline Opbrengst minus kosten & 209726 & -946 & -946 & -10863 & -7709 & -17177 & -17718 & -946 \\
\hline $\begin{array}{l}\text { Opbrengst minus kosten exclusief inkomsten } \\
\text { uit voerverkoop }\end{array}$ & 196921 & -946 & -946 & -10863 & -1657 & -4374 & -4914 & -946 \\
\hline $\begin{array}{l}\text { 1) Inclusief kosten voor toediening kunstmest } \\
\text { 2) Inclusief opslag en pletten } \\
\text { 3) Betreft de kosten voor mestafvoer, toedien } \\
\text { 4) Exclusief kosten bewaring veldboon. }\end{array}$ & exclusief & sten kunstr & en maï & n toedi & dierlijke & est (t.b. & gewa & \\
\hline
\end{tabular}

\section{Teelt, bemesting en voeropslag}

Hoewel er in voederwaarde opbrengst geen verschillen waren tussen de scenario's waarin alleen het aandeel blijvend en tijdelijk grasland varieerde (NON-1, NON-2, NON-3, NON-4 en NON-8), waren er grote verschillen in de kosten van de teelt van het gras en met name de post "Herinzaai tijdelijk en blijvend grasland" (Tabel 7.1).

Wanneer het aandeel blijvend grasland veranderde van 50\% naar 75\% van het grasland areaal en het aandeel 4-jarig grasland ( $50 \%$ van het graslandareaal) veranderde naar 2 -jarig grasland (25\% van het graslandareaal) (NON-2, NON-3 en NON-8) bleven de herinzaaikosten nagenoeg gelijk (stijging van $€ 946,-)$.

Echter bij NON-4 waar al het grasland werd omgezet naar 2-jarig grasland werden de herinzaaikosten $€$ 12.303,- hoger t.o.v. de referentie (NON-1). Er hoefden echter geen kosten meer gemaakt te worden voor de teelt van vanggewassen. De overige kosten bleven nagenoeg gelijk aan die van de referentie.

Ook in het scenario waar 5 ha van het graslandareaal werd vervangen door voederbieten (NON-5), was al het grasland 2-jarig. Hierdoor waren de herinzaaikosten $€$ 9937,- hoger t.o.v. de referentie. Omdat er 5 ha minder gras werd verbouwd t.o.v. de referentie waren de kosten voor de teelt van het gras $€ 6523$,- lager. De teeltkosten voor de voederbieten bedroegen $€ 10954,-$. Er hoefden geen kosten meer gemaakt te worden voor de teelt van vanggewassen. De kosten voor meststoffen waren $€ 5392$,- hoger doordat er meer mest afgezet moest worden. De kosten voor het toedienen van de meststoffen viel iets lager uit. Door de opslag van de voederbieten viel de post opslag en bewaring hoger uit $(€ 1222,-)$. 
In de scenario's waar de helft van het maïsareaal is vervangen door veldboon (NON-6 en NON-7) waren de kosten voor de teelt en opslag en bewaring van maïs lager t.o.v. de referentie. De kosten voor de teelt, pletten en opslag van de veldboon waren daarentegen $€ 10737$,- hoger. De overige kosten waren nagenoeg gelijk t.o.v. de referentie (Tabel 7.1).

\section{Opbrengst minus kosten}

De opbrengsten minus de kosten zijn met name voor de scenario's NON-4, NON-6 en NON-7 fors lager t.o.v. de referentie (NON-1). Voor NON-6 en NON-7 wordt dit met name veroorzaakt doordat er geen graskuil overschot is dat verkocht kan worden. Bij NON-4 wordt dit veroorzaakt door de hogere kosten voor herinzaai omdat al het grasland is omgezet naar tijdelijk 2-jarig grasland t.o.v. de referentie met $50 \%$ blijvend en $50 \%$ 4-jarig grasland.

De verkoop van het overschot aan kuilgras is sterk bepalend voor de post "Opbrengst minus kosten" zoals de post "Opbrengst minus kosten exclusief inkomsten uit voerverkoop" laat zien bij de scenario's NON-5, NON-6 en NON-7.

\subsubsection{Akkerbouw}

In Figuur 7.3 zijn de resultaten weergegeven van de economische bouwplanberekening voor het referentiebouwplan en de bouwplanvarianten op het akkerbouwbedrijf. In het economisch bouwplan van de akkerbouwer zijn er alleen veranderingen bij NON-4, NON-5 en NON-8. Bij NON-4 en NON-5 is er een volledig geïntegreerde gewasrotatie van de akkerbouw- en melkveehouderijgewassen. De verschillen met de referentie zijn klein, omdat de gewasaandelen niet veranderen en er alleen verschillen zijn in de kosten van het gebruik van meststoffen. Bij NON-4 en NON-5 zijn deze wat lager doordat er relatief veel aardappelen na gras worden geteeld en er kan worden bespaard op de Nbemesting. Voor NON-3 is het gemiddelde saldo wel duidelijk lager door een lager aandeel aardappelen en suikerbieten en een hoger aandeel zomergerst, zaaiuien en de toename van de kosten voor de groenbemester (na zomergerst) in het bouwplan. Daarbij moet voor de zaaiuien ook rekening gehouden worden met extra loonwerkkosten voor het rooien $€ 255 \mathrm{p} / \mathrm{ha}$ wanneer de betreffende mechanisatie op het bedrijf ontbreekt. Ook het saldo van NON-8 ligt in vergelijking tot de andere scenario's iets lager door een verschuiving binnen het bouwplan van zomergerst naar veldbonen. Binnen dit scenario is ervan uit gegaan dat de akkerbouwer de veldbonen oogst met een reeds aanwezig combine op het bedrijf. Het saldo van veldbonen is lager dan dat van zomergerst.



Figuur 7.3 Overzicht gemiddelde bouwplansaldo's Noordoost-Nederland.

\subsubsection{Nutriënten en organische stof}

Het N-bodemoverschot varieert tussen 105 en $135 \mathrm{~kg} \mathrm{~N}$ per ha op het melkveebedrijf en tussen 80 en $105 \mathrm{~kg} \mathrm{~N}$ per ha op het akkerbouwbedrijf (Figuur 7.4). Ten opzichte van de uitgangssituatie (NON-1) doen de grootste veranderingen zich voor bij de scenario's met een volledig geïntegreerd bouwplan (NON-4 en NON-5). Bij NON-4 daalt het overschot op het akkerbouwbedrijf, omdat er na het 2-jarige grasland aardappelen worden geteeld, waardoor er minder $\mathrm{N}$ nodig is door de nalevering van het gescheurde gras. In variant NON-5 vervalt de derogatie, waardoor het dierlijke mestgebruik bij de melkveehouderijgewassen daalt en daardoor het bodemoverschot daalt. In dit scenario gaat er meer 
rundveemest naar de gewassen van de akkerbouwer, waardoor daar het bodemoverschot stijgt in vergelijking met variant NON-4.

Vervanging van maïs door veldbonen op het melkveebedrijf (NON-6 en NON-7) leidt tot een gelijkblijvend of lichte daling van het overschot. Het laatste is ook het geval wanneer op het akkerbouwbedrijf de zomergerst wordt vervangen door veldboon (NON-8).

Het effect van de scenario's op het $\mathrm{P}_{2} \mathrm{O}_{5}$-bodemoverschot is relatief gering en loopt voor het melkveebedrijf uiteen van 3-5 kg $\mathrm{P}_{2} \mathrm{O}_{5}$ per ha en op het akkerbouwbedrijf van $11-12 \mathrm{~kg} \mathrm{P}_{2} \mathrm{O}_{5}$ per ha (Figuur 7.4).



Figuur 7.4 Het $\mathrm{N}$ - en $\mathrm{P}_{2} \mathrm{O}_{5}$-bodemoverschot $(\mathrm{kg} / \mathrm{ha}$ ) van het melkvee- en akkerbouwbedrijf bij de verschillende bouwplanscenario's in Noordoost-Nederland.

In Figuur 7.5 is de aanvoer van effectieve organische stof (EOS) weergegeven. In de bovenste figuur is onderscheid gemaakt tussen de verschillende rotaties binnen de samenwerking die fysiek van elkaar gescheiden zijn (blijvend grasland, wisselbouw op melkveebedrijf en rotatie op akkerbouwbedrijf), in de onderste figuur is de totale aanvoer op de grond van de beide bedrijven weergegeven.

De grootste veranderingen treden op bij het wisselbouwdeel van het melkveebedrijf en op het akkerbouwbedrijf. Verkorting van de grasperiode in de wisselbouw op het melkveebedrijf (vergelijk NON-2 met NON-1) leidt logischerwijs tot een wat lagere EOS-aanvoer door het lagere grasaandeel in het wisselbouwdeel van het melkveebedrijf. De volledig geïntegreerde rotaties leiden tot een verlaagde aanvoer op het wisselbouwdeel van het melkveebedrijf en een sterk verhoogde EOSaanvoer op het akkerbouwbedrijf. Op het niveau van de totale samenwerking is er echter weinig verschil met situaties met beperkte grondruil (NON-1/2/3).

Vervanging van maïs door veldbonen op het melkveebedrijf (NON-6 en NON-7) en vervanging van zomergerst door veldbonen op het akkerbouwbedrijf (NON-8) heeft slechts een gering effect op de EOS-aanvoer. 


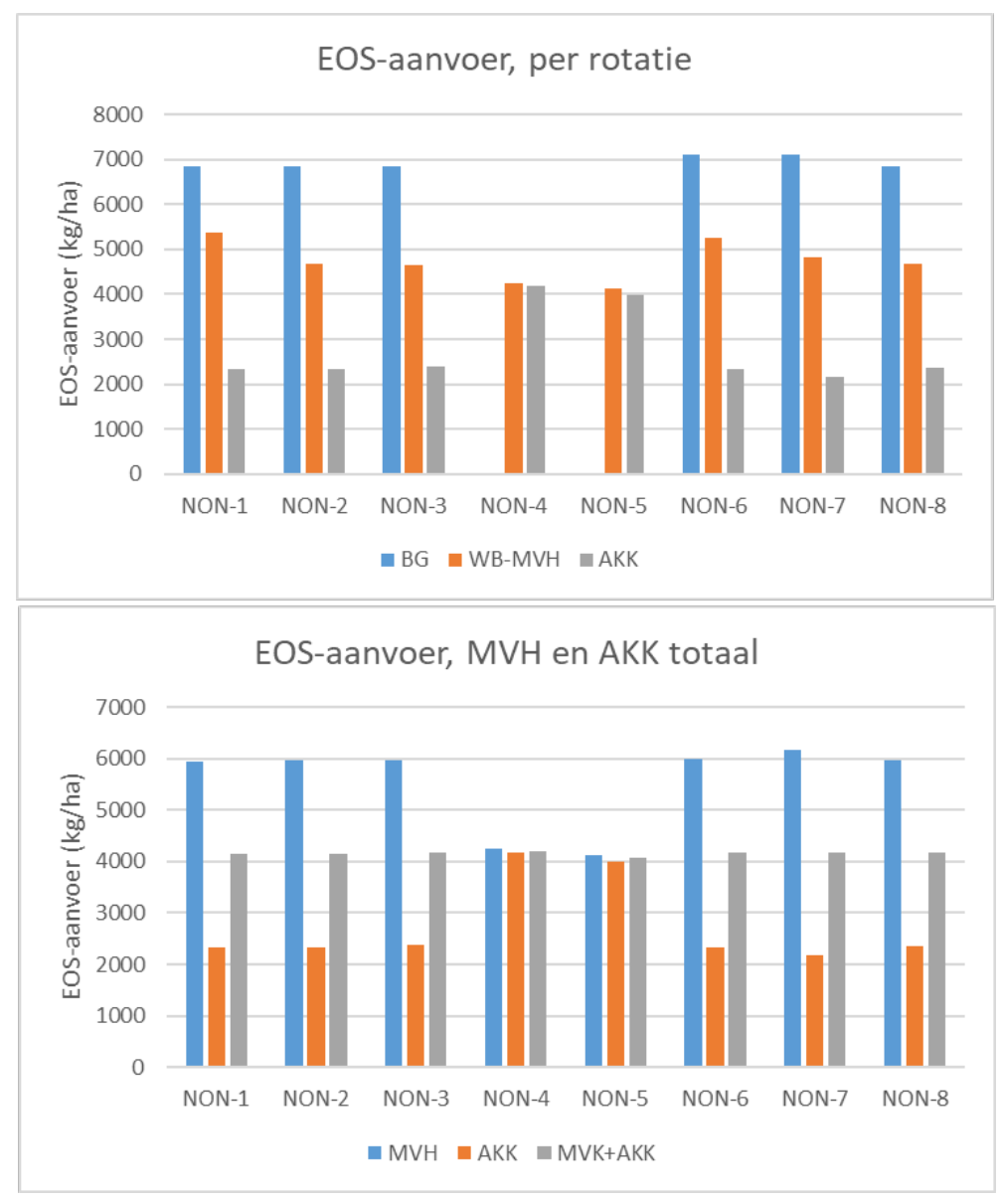

Figuur 7.5 De aanvoer van effectieve organische stof (EOS, $k g$ per ha) op de grond van het melkveebedrijf ( $B G=$ blijvend grasland, $W B=$ wisselbouw $)$ en het akkerbouwbedrijf bij de verschillende bouwplanscenario's in Noordoost-Nederland.

\subsubsection{Broeikasgasemissies}

In Tabel 7.2 is voor de verschillende bouwplanvarianten het verschil in broeikasgasemissies (BKGemissies) met de referentievariant weergegeven. Een hoger aandeel blijvend grasland (60\% i.p.v. $40 \%, \mathrm{NON}-2$ ) leidt tot een geringe daling van de BKG-emissies. Een volledige integratie van de bouwplannen van het melkvee- en akkerbouwbedrijf (NON-4) leidt per saldo tot een lichte daling van de BKG-emissies. Dit komt door een iets lager kunstmest-N-gebruik, doordat de N-gebruiksnorm lager is voor de bouwlandgewassen in het jaar na het scheuren van gras. In een volledig geïntegreerde rotatie is er meer tijdelijke grasland en is er een groter areaal bouwland dat wordt geteeld na gescheurd gras. In variant NON-5 is er ook sprake van een volledig geïntegreerde rotatie, maar is er op het melkveebedrijf geen derogatie meer en naast maïs worden er voederbieten geteeld. Dit leidt tot een daling van de emissies. Dit is vooral een gevolg van een verlaagde krachtvoeraankoop.

Vervanging van de een deel van de maïs door veldbonen op het melkveebedrijf (NON-6 en NON-7) en vervanging van een deel van de zomergerst door veldbonen (NON-8) geven slechts kleine veranderingen in de BKG-emissies. 
Tabel 7.2 Effect van de bouwplanaanpassingen in NON op de hoeveelheid broeikasgasemissies ( $\mathrm{kg}$ CO2-eq/ha) voor zowel het melkveebedrijf (MVH) als het akkerbouwbedrijf (AKK), uitgedrukt als verschil t.o.v. het referentiebouwplan.

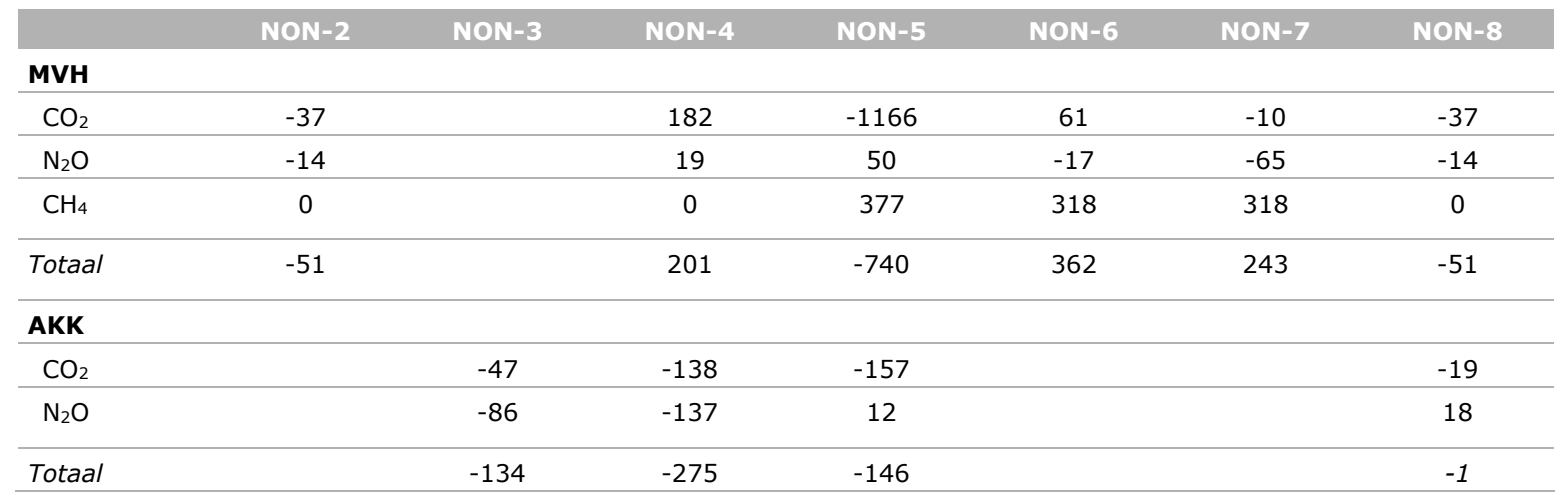

\subsubsection{Bodemgezondheid}

De aardappelteelt is zowel op een melkveebedrijf als op een akkerbouwbedrijf een teelt die extra aandacht vergt, waarbij het doel van de aardappelteelt doorslaggevend is voor de problemen die van bodempathogenen en -plagen zijn te verwachten. De gestelde eisen ten aanzien van het vóórkomen van pathogenen en plagen bij verschillende vormen van aardappelteelt variëren. Voor de teelt van pootgoed mag er geen $G$. rostochiensis of $G$. pallida op het betreffende perceel zijn gevonden, het pootgoed zelf moet vrij zijn van $M$. chitwoodi en $M$. fallax en maximaal $6 \%$ van de aardappelen mag kringerigheid (Tabaksratelvirus (TRV), dat wordt overgebracht door trichodoriden) vertonen. Bij de teelt van consumptieaardappelen zijn er bepaalde kwaliteitseisen, die daarentegen niet worden gesteld aan de teelt van zetmeelaardappelen. Bij de teelt van consumptieaardappelen zijn $M$. chitwoodi en $M$. fallax een probleem door kwaliteitsschade in de vorm van uitwendige knobbels, waaronder zich de eipakketten van de nematoden bevinden. In de praktijk wordt deze kwaliteitsschade beperkt door de teelt van een minder gevoelig ras, een vroege teelt en vroege oogst en/of toedienen van granulaat. Maximaal $2 \%$ van de consumptieaardappelen mag kringerigheid (TRV) vertonen. Bij de teelt van consumptie- en zetmeelaardappelen zorgen G. rostochiensis en G. pallida voor een reductie van de opbrengst, maar worden er geen eisen gesteld aan het vóórkomen van deze nematoden in de grond. Bij de teelt van zetmeelaardappelen zijn er geen restricties aan het vóórkomen van kringerigheid, $M$. chitwoodi en M. fallax, al kan M. fallax in hoge dichtheden een oogstderving tot gevolg hebben. De aanwezigheid van andere nematoden, zoals $M$. hapla, $P$. penetrans, D. dipsaci en trichodoriden (in het Noordoostelijk zandgebied voornamelijk $P$. pachydermus en $T$. similis) spelen bij alle drie vormen van aardappelteelt dezelfde rol.

In de huidige rotatie van een melkveebedrijf (G-G-G-G-MA-PA; NON-1) kan de teelt van gras een probleem vormen voor de aardappelteelt. Zowel $M$. fallax als trichodoriden vermeerderen zich sterk op Engels raaigras (Figuur 7.6). Een tussenteelt van maïs, zoals hier het geval, kan de aantallen van deze nematoden doen verlagen, maar wel de aantallen $M$. chitwoodi en $P$. penetrans verhogen. Ook bij de keuze van een groenbemester na de maïsteelt is het belangrijk om rekening te houden met de aanwezigheid van nematoden. Winterrogge en Italiaans raaigras kunnen $M$. chitwoodi sterk vermeerderen, met nadelige gevolgen voor de aardappelteelt. Meloidogyne fallax daarentegen vermeerdert sterk op zowel Italiaans als Engels raaigras, maar minder op winterrogge. Pratylenchus penetrans vermeerdert het sterkst op Italiaans raaigras. Een grondbemonstering om de uitgangssituatie in beeld te brengen is daarom belangrijk. Bij tijdelijk grasland kan Meloidogyne naasi, maar ook ritnaalden een probleem vormen bij het aanslaan van het gewas. Waar bij blijvend grasland wellicht geen schade is te zien, zijn jonge planten gevoeliger voor aantasting dan oudere planten (NON-1 ten opzichte van NON-2).

Netschurft (Streptomyces spp.) bij aardappel komt op alle grondsoorten voor (Agris, 2000). Het tast niet alleen de knollen aan, maar alle ondergrondse delen van de plant en heeft zowel verlies in kwantiteit als kwaliteit tot gevolg. De aantasting kan ook op gescheurd grasland in ernstige mate optreden. De aantasting is het hevigst bij hoge bodemvochtigheid, in tegenstelling tot gewone schurft. Ook bij een teelt van 1:3 of 1:4 kan netschurft optreden bij vatbare rassen. Het telen van niet-vatbare rassen is aan te raden wanneer een perceel sterk is besmet. 
De gestreepte kniptor (Agriotes lineatus) kan zich matig vermeerderen op grassen. Ritnaalden, de larven van deze tor, veroorzaken matige schade bij grassen, maar kunnen zware schade veroorzaken bij aardappel (Qiu et al. 2013). Vanwege de 4-jarige levenscyclus zijn de risico's op problemen met ritnaalden kleiner bij 1- of 2-jarig grasland dan bij 3- of 4-jarig grasland.

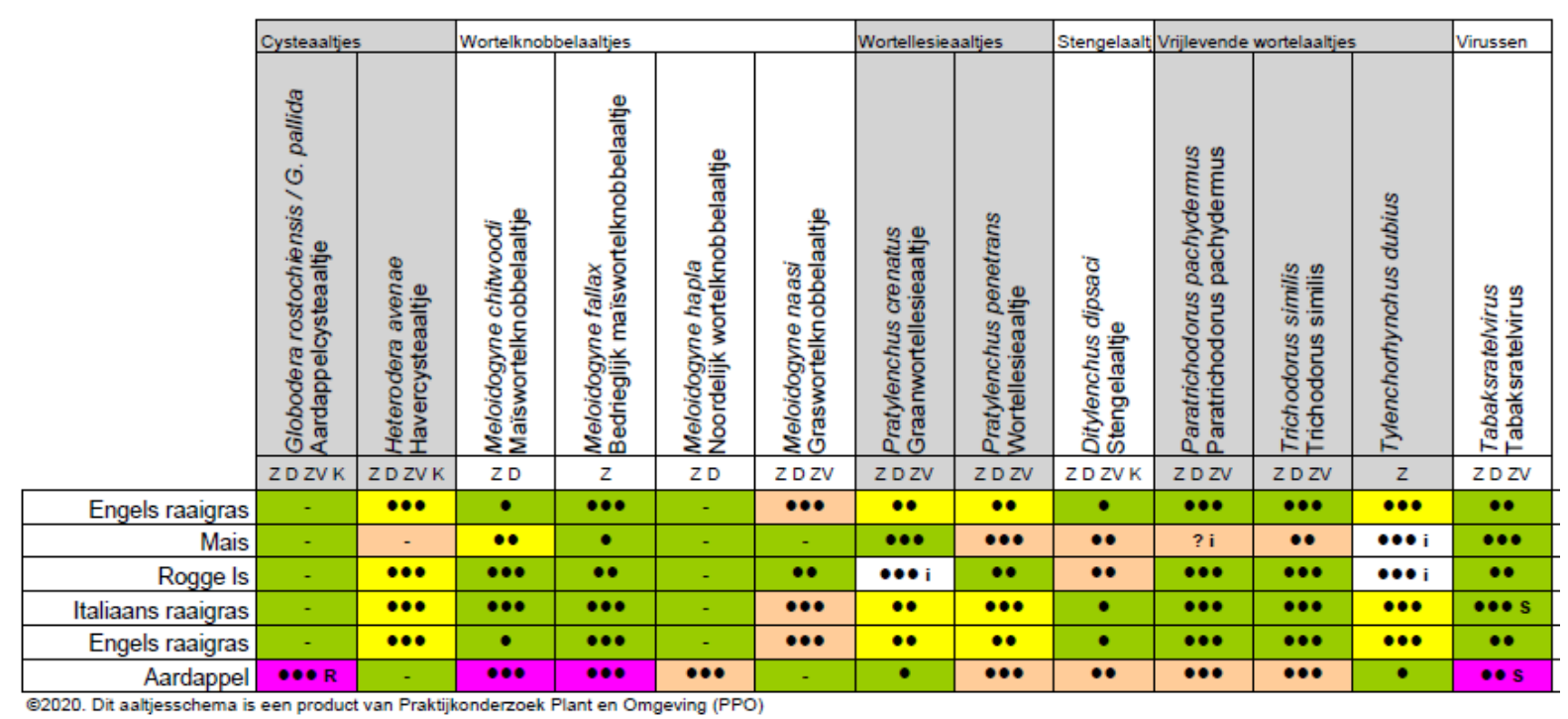

Figuur 7.6 Vermeerdering van en schade door nematoden in Noordoost-Nederland op een melkveebedrijf in de huidige situatie met samenwerking met een akkerbouwbedrijf. Er worden in dit schema drie mogelijke groenbemesters na maïs gepresenteerd: rogge, Italiaans en Engels raaigras. Deze rotatie geldt ook voor de situatie waarin door samenwerking met het akkerbouwbedrijf pootaardappel door zetmeelaardappel wordt vervangen, waarbij wel de eisen aan vóórkomen van bepaalde nematodensoorten veranderen (zie tekst). Rotaties G-G-(G-G-)MA-Groenbemester-PA met meer of minder jaren grasland (NON-1, NON-2, NON-7 en NON-8) en G-G-MA-Groenbemester-ZA (NON-3).

In het aaltjesschema is geen informatie over de vatbaarheid en waardplantstatus van voederbiet beschikbaar. In plaats daarvan is gekozen om suikerbiet op te nemen in het schema (NON-5; Figuur 7.7). Aangezien er minder veredeling heeft plaatsgevonden aan dit gewas met betrekking tot vatbaarheid voor nematoden, kan verwacht worden dat bij voederbiet meer problemen met nematoden zullen optreden dan bij suikerbiet. Voederbiet vermeerdert zowel $H$. betae als $H$. schachtii goed. Een teelt van 1:4 is te nauw om schade door $H$. schachtii te voorkomen indien deze nematoden aanwezig zijn, maar is wel ruim genoeg om problemen met $H$. betae te voorkomen. Vroeg zaaien kan de schade door beide nematodensoorten wel verminderen, doordat suikerbiet bij lagere temperaturen al wel groeit, terwijl $H$. schachtii pas bij $8^{\circ} \mathrm{C}$ en $H$. betae bij $15^{\circ} \mathrm{C}$ actief wordt. 


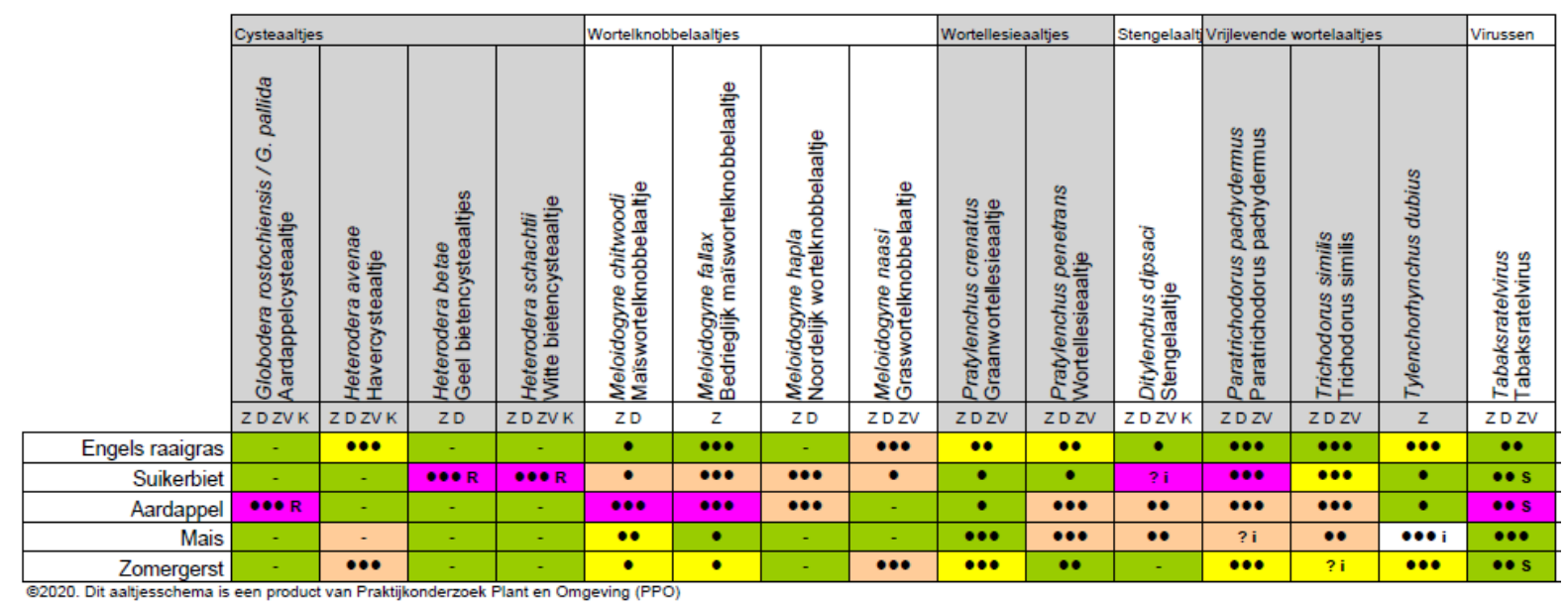

Figuur 7.7 Vermeerdering van en schade door nematoden in Noordoost-Nederland op een melkveebedrijf bij volledige integratie met een akkerbouwbedrijf. Vanwege ontbreken van voederbiet in aaltjesschema is hier voor suikerbiet gekozen, met als kanttekening dat voederbiet minder is veredeld en resistente rassen niet beschikbaar zullen zijn. Vierjarige rotaties $G-G-Z A+P A-M A+Z G$ (NON-4) en $G-G+V B-Z A+P A-M A+Z G(N O N-5)$.

Vanwege de samenwerking met een melkveebedrijf, wordt er in de huidige situatie op het akkerbouwbedrijf een jaar maïs geteeld in plaats van zomergerst. De teelt van maïs kan de aantallen $P$. penetrans en $D$. dipsaci sterker doen toenemen dan de teelt van zomergerst (Figuur 7.8), wat ongunstig is voor de aardappelteelt. Daarentegen kan M. fallax zich sterker vermeerderen op zomergerst dan op maïs. Ook bij de keuze van de groenbemester na de zomergerst- of maïsteelt zal rekening gehouden moeten worden met de aanwezige aaltjes. Bladrammenas vermeerdert $P$. penetrans sterk, terwijl Japanse haver dit niet doet. Een zomerteelt met Tagetes patula kan de besmetting met $P$. penetrans nagenoeg saneren. In dat geval zal de keuze wellicht op resistente bladrammenas vallen, waarmee een besmetting met $M$. chitwoodi verlaagd kan worden. Na maïs is in de meeste gevallen Engels raaigras de beste keuze als groenbemester, omdat $M$. chitwoodi en $P$. penetrans minder sterk vermeerderen dan op Italiaans raaigras of winterrogge. De vermeerdering van M. fallax is juist iets lager op winterrogge dan op de raaigrassen, al laat ook rogge een matige vermeerdering zien.

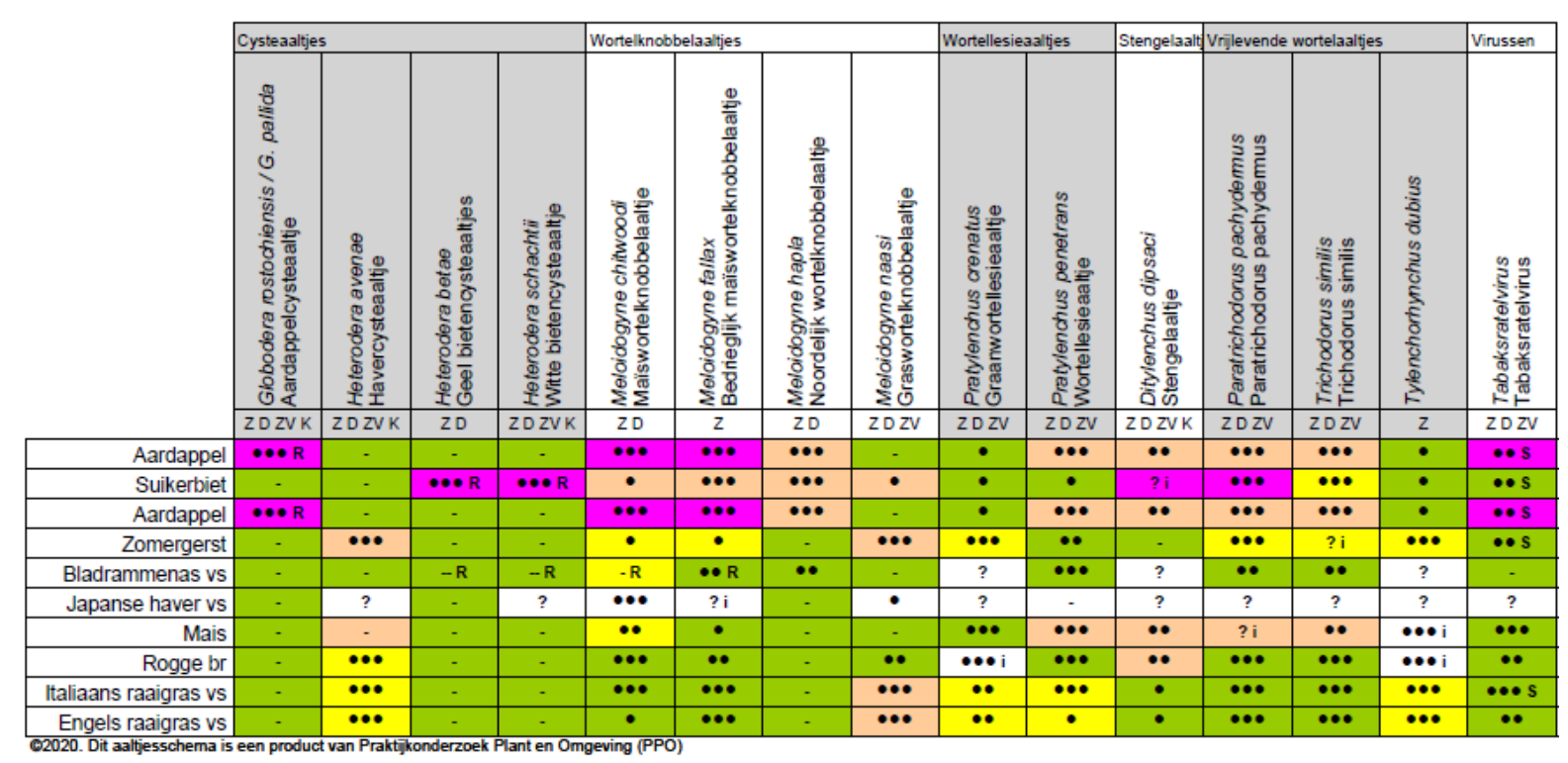

Figuur 7.8 Vermeerdering van en schade door nematoden in Noordoost-Nederland op een akkerbouwbedrijf in de huidige situatie met samenwerking met een melkveebedrijf. In het vierde jaar van de rotatie wordt ofwel zomergerst of maïs verbouwd. Vierjarige rotaties $Z A-S B-Z A-Z G$ Groenbemester (uitgangssituatie) en ZA-SB-ZA-ZG-Groenbemester+MA-Groenbemester (NON-1, NON-2 en NON-6). 
In Noordoost-Nederland is de teelt van zetmeelaardappelen in de huidige situatie zeer intensief (1:2;

Figuur 7.8). Verruimen van de rotatie door verplaatsen van een deel van de zetmeelaardappelteelt naar een melkveebedrijf zou gunstig kunnen zijn om optreden van bodempathogenen en -plagen te verminderen. Toch is een teelt van 1:3 nog te intensief om aardappelmoeheid (schade door aardappelcysteaaltjes) te voorkomen (NON-3; Figuur 7.9). De teelt van zomergerst kan wel de aantallen van $M$. hapla doen verlagen. Ook Japanse haver als groenbemester verlaagt de aantallen van zowel $M$. hapla als $P$. penetrans, wat gunstig is voor de daaropvolgende aardappelteelt. Invoegen van een uienteelt in het bouwplan kan de aantallen M.chitwoodi en $M$. fallax verlagen, maar $P$. penetrans en $D$. dipsaci verhogen en de uien kunnen daarvan zelf ook schade ondervinden.

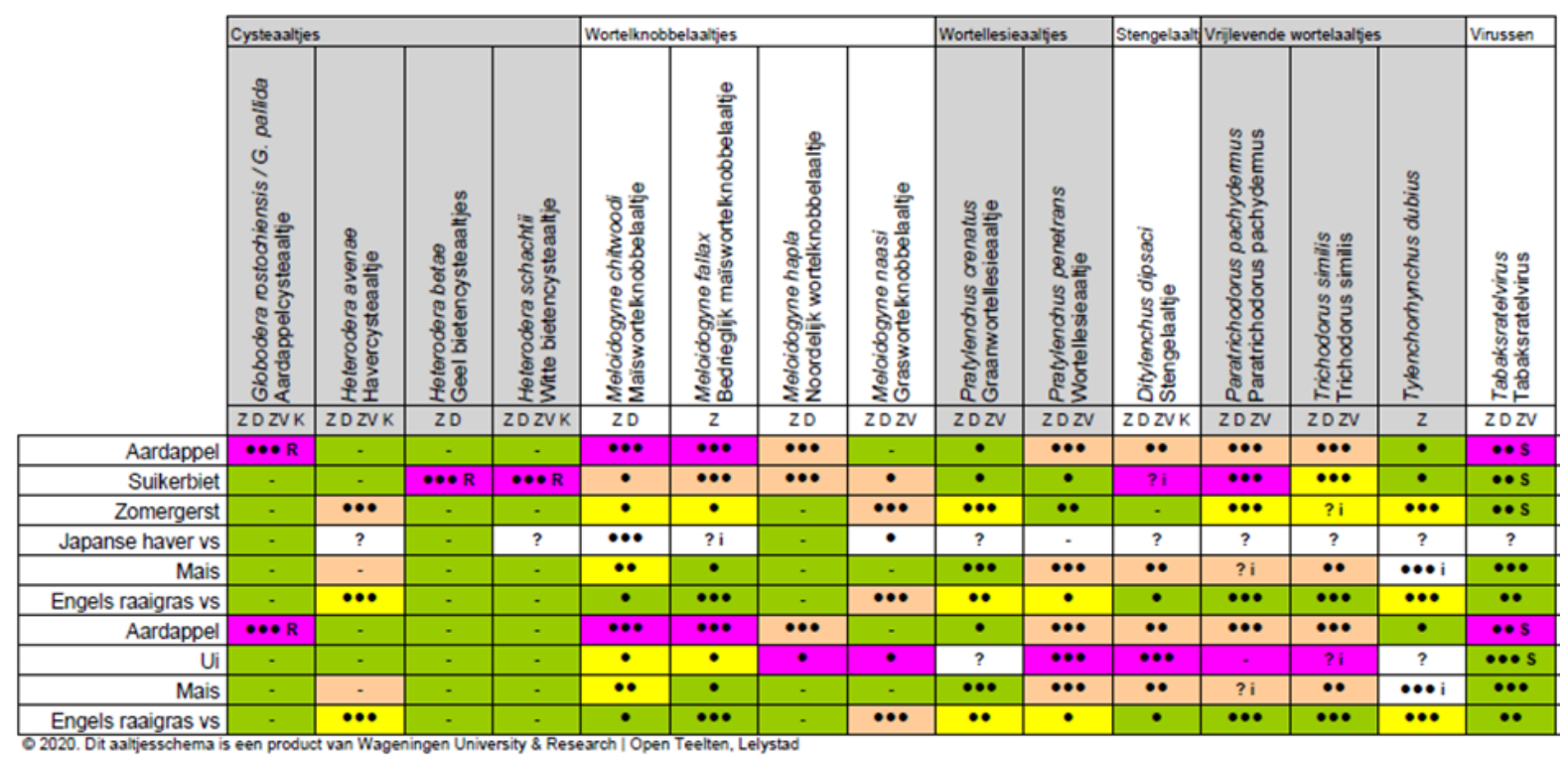

Figuur 7.9 Vermeerdering van en schade door nematoden in Noordoost-Nederland op een akkerbouwbedrijf bij verruimen van de teeltfrequentie van 1:2 naar 1:3 door verplaatsen van een zetmeelaardappelteelt naar een melkveebedrijf. Voor andere mogelijkheden voor de groenbemesterkeuze zie Figuur 7.8. Rotatie ZA-SB-ZG-Groenbemester-ZA-SB-ZGGroenbemester+MA-Groenbemester-ZA-UI-MA-Groenbemester (NON-3).

Een andere mogelijkheid om de rotatie op het akkerbouwbedrijf te verruimen, is door volledige integratie met een melkveebedrijf (NON-4 en NON-5). Hierbij vindt grasteelt plaats op een deel van het bedrijf, terwijl de huidige rotatie op een ander deel van het bedrijf in stand wordt gehouden (Figuur 7.6 en Figuur 7.10). Voor de aardappelteelt betekent de afwisseling met twee jaar gras een verruiming van de vruchtwisseling. Dit is gunstig voor natuurlijke afname van aardappelcysteaaltjes (Globodera-soorten). Een tussenteelt gras kan de aantallen $P$. penetrans doen afnemen, maar de aantallen $M$. fallax doen toenemen ten opzichte van de rotatie met zomergerst. Het is dus afhankelijk van de aanwezige nematodensoorten of dit een gunstig effect heeft. 


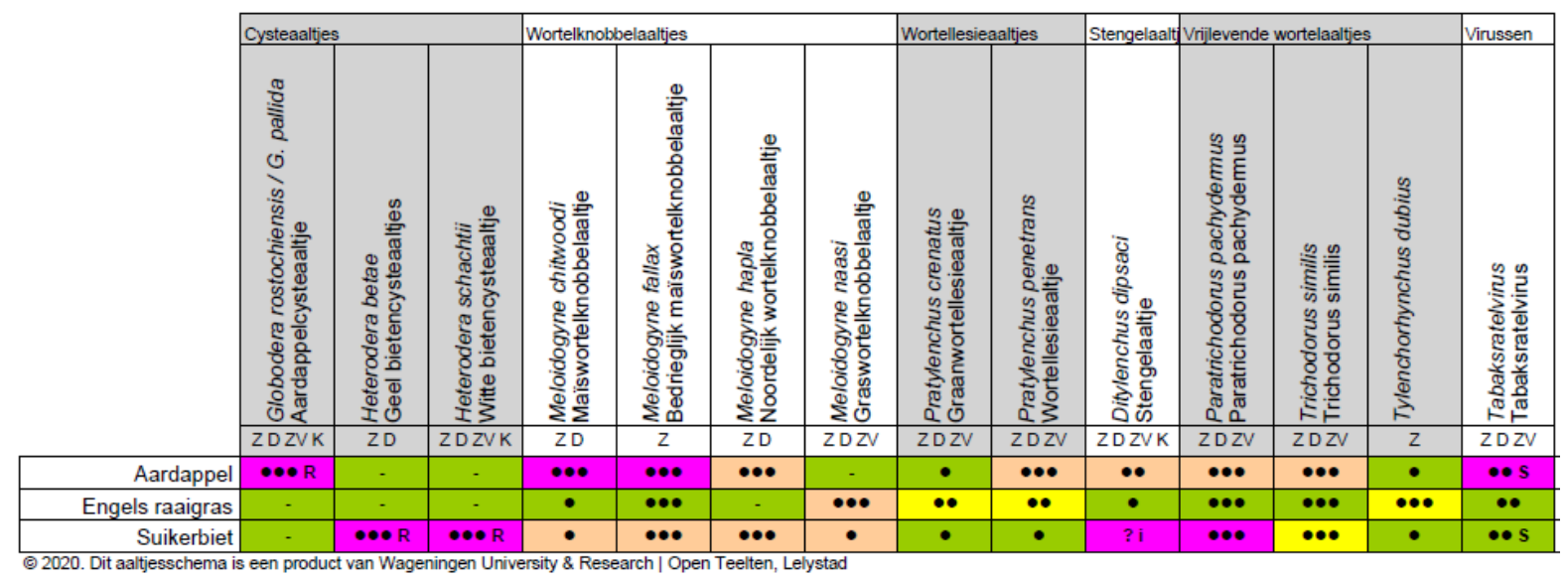

Figuur 7.10 Vermeerdering van en schade door nematoden in Noordoost-Nederland op een akkerbouwbedrijf bij volledige integratie van de bouwplannen met een melkveebedrijf. Rotatie ZA$G+S B-G+Z A-S B+Z G$. Op perceelsniveau betekent dit, dat twee verschillende rotaties worden toegepast: op één deel van het bedrijf een vierjarige rotatie $Z A-S B-Z A-Z G$-Groenbemester (uitgangssituatie, zie Figuur 7.8) en op een ander deel van het bedrijf een vierjarige rotatie ZA-G-GSB (NON-4 en NON-5).

De teelt van eiwithoudende gewassen kan zowel op het melkveebedrijf als op het akkerbouwbedrijf plaats vinden. Voor beide situaties zijn scenario's bekeken waarbij gekozen is voor veldboon (NON-6, NON-7, NON-8). Het in kaart brengen van mogelijke problemen met bodempathogenen en -plagen kan, samen met een grondbemonstering, helpen om de afweging te maken bij welk bedrijf deze teelt het beste zou kunnen plaatsvinden. De teelt van veldboon als eiwithoudend gewas vormt, gezien de andere gewassen in de rotatie, een groter risico voor het akkerbouwbedrijf dan voor het melkveebedrijf. De teelt van veldboon kan de aantallen $H$. betae verhogen. Dit is geen probleem voor de andere gewassen op een melkveebedrijf (Figuur 7.11), maar wel voor de teelt van suikerbieten op een akkerbouwbedrijf (Figuur 7.12). Een bietenteelt bij een teelfrequentie van 1:4 is alleen mogelijk in een bouwplan zonder andere gewassen die $H$. betae vermeerderen. Een zomerteelt van resistente bladrammenas als groenbemester (in plaats van een hoofdgewas) kan de aantallen $H$. betae sterk verminderen, maar het is wel van belang dat het gewas vroeg genoeg wordt gezaaid. Een sterke vermeerdering van $D$. dipsaci kan, afhankelijk van het stengelaaltjesras, problemen geven bij de teelt van suikerbiet, al zijn hier nog geen zekere uitspraken over te doen. Ook M. hapla vermeerdert zich op veldboon, wat zowel schade kan veroorzaken in de aardappel- als in de suikerbietenteelt. Er is geen informatie beschikbaar over de vermeerdering van M. chitwoodi, M. fallax, $P$. crenatus en trichodoriden op veldboon, waardoor er geen inschatting te maken is van de gevolgen voor de teelt van andere gewassen. Zowel S. sclerotiorum (rattenkeutelziekte) als $V$. dahliae (verwelkingsziekte) kunnen op veldboon vermeerderen en daarna problemen geven in de aardappelteelt (Figuur 4.1), zowel op het melkvee- als op het akkerbouwbedrijf.

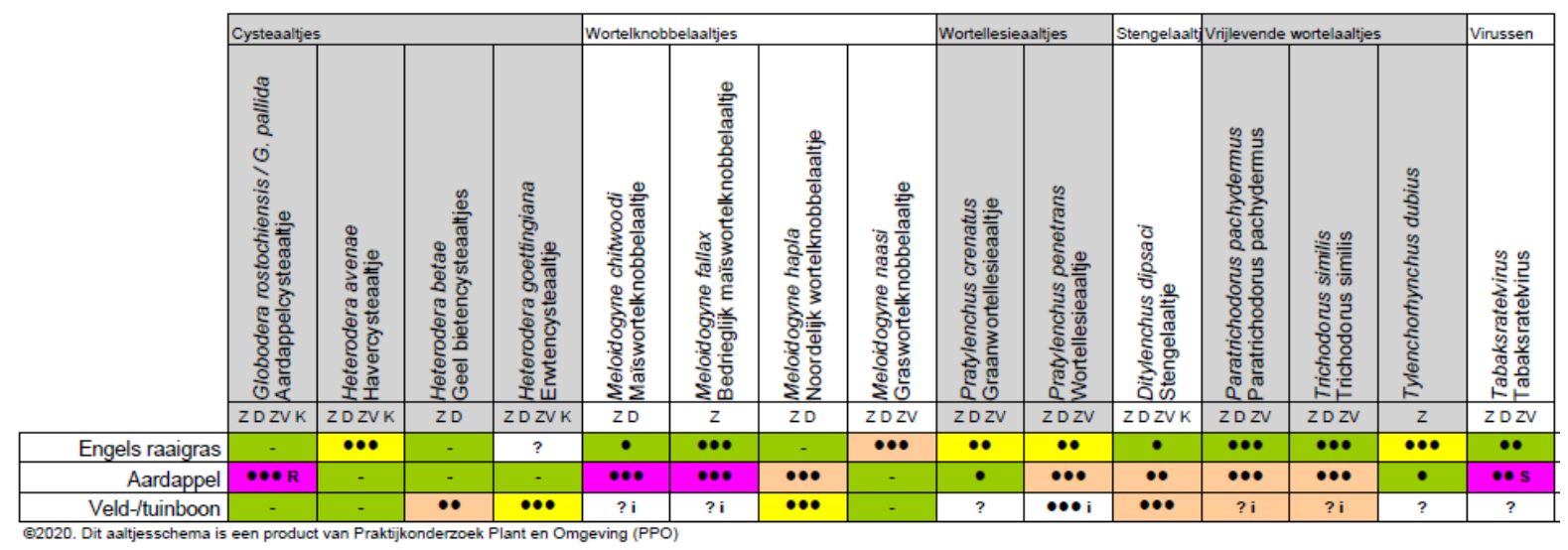

Figuur 7.11 Vermeerdering van en schade door nematoden in Noordoost-Nederland op een melkveebedrijf bij vervangen van maïs door veldboon. Rotatie G-G-G-G-PA-VBO (NON-6). 


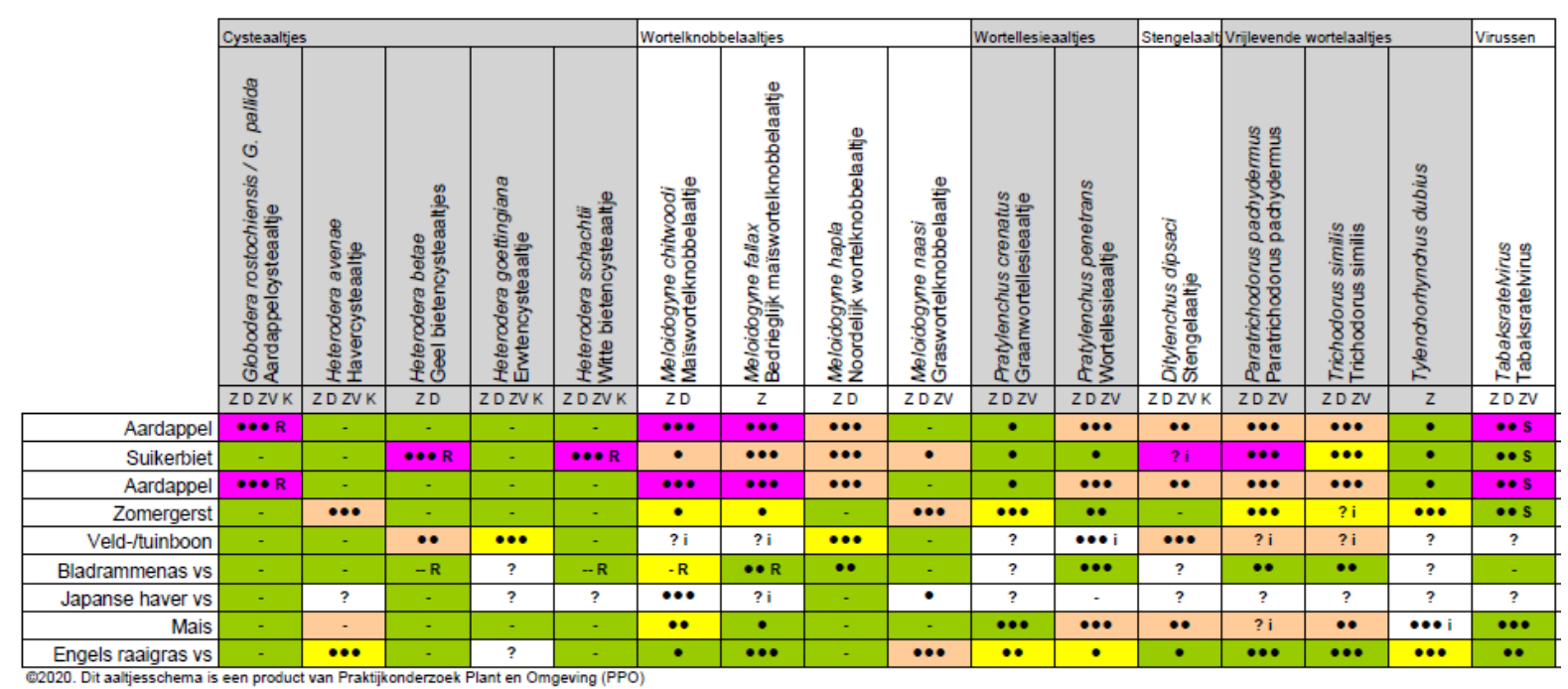

Figuur 7.12 Vermeerdering van en schade door nematoden in Noordoost-Nederland op een akkerbouwbedrijf bij vervangen van zomergerst of maïs door veldboon. Rotaties ZA-SB-ZA-ZGGroenbemester+VBO-Groenbemester (NON-7) en ZA-SB-ZA-VBO-Groenbemester+MA-Groenbemester (NON-8).

\subsection{Zuidoost-Nederland (ZON)}

\subsubsection{Economie}

\subsubsection{Melkveehouderij}

\section{Voederwaarde opbrengst}

Met de teelt van 9 ha blijvend grasland, 27 ha 3-jarig grasland en 9 ha maïs was de voederwaardeopbrengst voor ZON-1 501 ton droge stof, 466805 kVEM, 66656 kg RE en 29159 DVE (Figuur 7.13).

In de scenario's ZON-2, ZON-3, ZON-4, ZON-4a en ZON-5 werden er veranderingen in het areaal grasland gedaan. Hoewel de scenario's ZON-2, ZON-3 en ZON-4 verschilden in het aandeel blijvend en tijdelijk grasland t.o.v. referentie $(Z O N-1)$ is de voederwaarde opbrengst voor deze scenario's gelijk omdat in deze studie de voederwaarde opbrengst voor tijdelijk en blijvend grasland in deze studie aan elkaar gelijk gesteld zijn.

Wanneer 27 ha grasland wordt beweid (ZON-4a), neemt de voederwaardeopbrengst af naar 460 ton droge stof, 432522 kVEM, 63570 RE en 28716 DVE t.o.v. de referentie (ZON-1).

Vervanging van het 3-jarige grasland door 3 jarige gras/rode klaver (ZON-5) laat een stijging van de droge stof en RE opbrengst zien t.o.v. de referentie naar respectievelijk 533,6 ton en $70300 \mathrm{~kg} R$. Echter de kVEM opbrengst en DVE opbrengst laten een daling zien naar respectievelijk 434650 kVEM en 26479 kg DVE. 

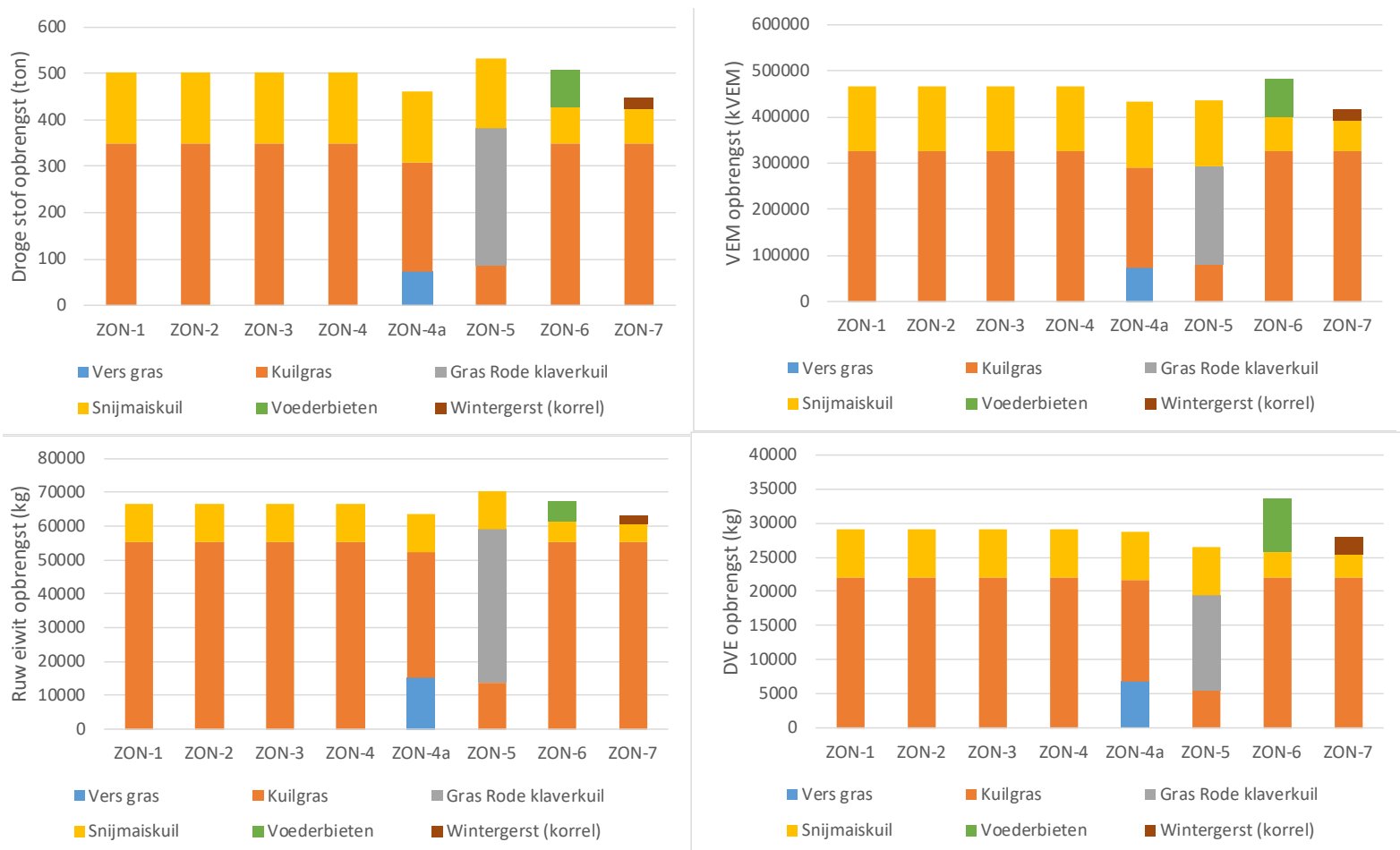

Figuur 7.13 Droge stof, KVEM, ruw eiwit en DVE opbrengst voedergewassen die op naam van het melkveehouderij bedrijf worden verbouwd in de scenario's ZON-1 t/m ZON-7.

In ZON-6 en ZON-7 werden er veranderingen in het bouwland areaal gedaan. Vervanging van de helft van het maïsareaal door voederbieten gaf een stijging van de voederwaarde opbrengst tot 507 ton droge stof, 481668 kVEM, $67338 \mathrm{~kg}$ RE en $33639 \mathrm{~kg}$ DVE. Echter gaf de vervanging van de helft van het maïsareaal door wintergerst een daling van de voederwaarde opbrengst tot 446,7 ton droge stof, 416901 kVEM, 63191 kg RE en 27936 kg DVE.

Een maat voor de hoeveelheid melk die een koe kan geven uit de beschikbare droge stof is de VEMDVE verhouding per eenheid VW. Figuur 7.14 laat de VEM-DVE verhouding per eenheid VW voor de geteelde droge stof en de gevoerde droge stof zien. De VEM-DVE verhouding per eenheid Verzadigingswaarde in de geteelde droge stof varieerde van 15,6 tot 17,7 en was 15,6 voor ZON-6, 16,2 voor ZON-7, 16,3 voor ZON-4a, 17,0 voor ZON1-t/m ZON-4 en 17,7 voor ZON 5 (Figuur 7.14).

De VEM-DVE verhouding per eenheid VW van de gevoerde droge stof was hoger en varieerde van 17,1 (ZON-6 en ZON-7) tot 20,5 (ZON-5). Voor ZON-1 t/m ZON-4 en ZON-4a was de VEM-DVE verhouding per eenheid VW 17,3.

Het verschil tussen de VEM-DVE verhouding per eenheid VW in de geteelde droge stof en de gevoerde droge stof was voor ZON-1 t/m ZON-4 het kleinst en voor ZON-5 het grootst. 


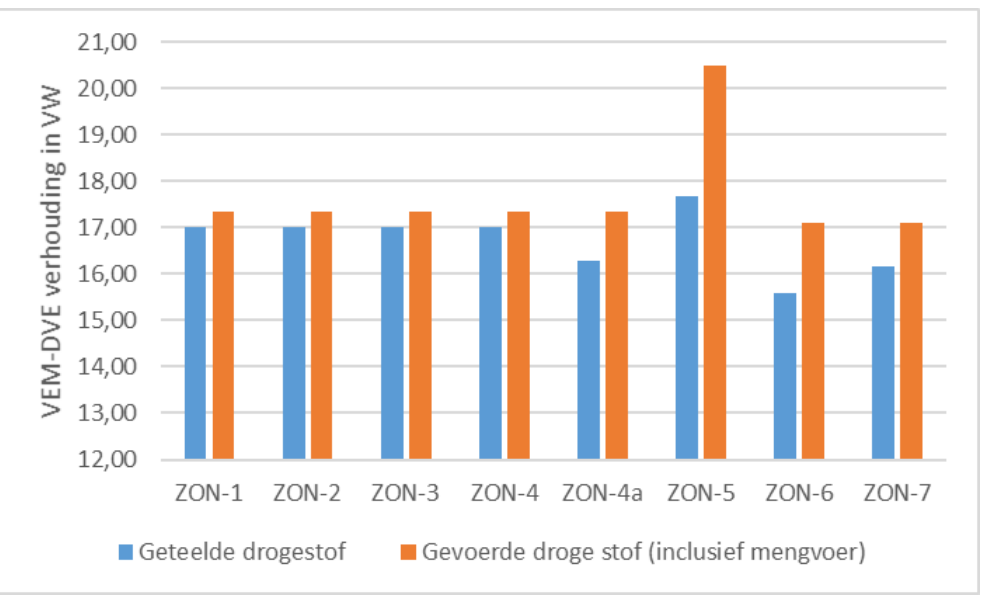

Figuur 7.14 VEM/DVE verhouding van respectievelijk de geteelde en gevoerde droge stof in de scenario's ZON-1 t/m ZON-7.

\section{Melkproductie}

Voor de scenario's ZON-1 t/m ZON-7 was het mogelijk om het niveau van de melkproductie te halen met het aantal dieren (jongvee en melkkoeien) zoals geformuleerd bij de bedrijfsopzet (Bijlage 8 , Tabel 6.1. De melkproductie varieerde weinig tussen de verschillende scenario's zoals de inkomsten uit melkgeld laten zien (Tabel 7.3). Hierbij is gerekend met een melkprijs van $€ 0,36$ per kg melk.

\section{Aan- en verkoop voer}

Tabel 7.3 laat zien dat er voor ZON-1 geen inkomsten uit de verkoop van voer zijn. Anderzijds wordt er $€ 75.381$,- aan voedermiddelen aangekocht. Dit betreft de aankoop van mengvoer en 44,6 ton droge stof uit snijmaïs.

Voor ZON-2 t/m ZON-4 zijn de aan- en verkoop van voer hetzelfde t.o.v. ZON-1.

Door 27 ha grasland te gaan beweiden (ZON-4a), zijn de voeraankopen $€ 11.526$,- hoger t.o.v. de referentie. Er wordt iets minder mengvoer, maar fors meer snijmaïs aangekocht; 44,6 ton droge stof versus 166,9 ton droge stof.

Wanneer het tijdelijke grasland wordt vervangen door gras-rode klaver (ZON-5) hoeft er geen snijmaïs aangekocht te worden, maar wel meer mengvoer. De kosten voor voeraankoop zijn hiermee $€ 4.312$,- hoger dan de referentie (ZON-1). Doordat er gras-rode klaver verkocht wordt, zijn de inkomsten uit voerverkopen $€ 2608$,- hoger t.o.v. de referentie.

Door de helft van het snijmaïs areaal te vervangen door voederbieten (ZON-6) kan er worden volstaan met de aankoop van minder krachtvoer. Het is dan echter wel nodig meer snijmaïs aan te kopen t.o.v. de referentie (64 ton versus 44,6 ton droge stof ). Hierdoor worden de kosten voor het aankopen van voer $€ 5861$,- lager t.o.v. de referentie.

Het vervangen van de helft van het snijmaïs areaal door wintergerst (ZON-7) resulteert in het aankopen van meer snijmaïs t.o.v. de referentie (129 ton versus 44,6 ton droge stof) en een lagere aankoop van krachtvoer. Hierdoor vallen de kosten voor de aankoop van voedermiddelen $€ 4360$,hoger uit t.o.v. de referentie.

Bijlage 6 geeft een overzicht van de hoeveelheden droge stof die met verscheidene producten zijn aangekocht en verkocht.

\section{Teelt, bemesting en voeropslag}

In de scenario's waar het aandeel blijvend grasland hoger was dan in de referentie (ZON-2, ZON-3, ZON-4 en ZON-4a) waren de kosten voor "Herinzaai tijdelijk en blijvend grasland" lager t.o.v. de referentie $(\mathrm{ZON}-1)$. 
Wanneer op 26 ha van het grasland beweiding werd toegepast (ZON-4a), werd er minder gras ingekuild, waardoor de kosten voor de teelt van het gras $€ 11.826$,- lager waren t.o.v. de referentie. Bovendien waren de kosten voor de aanschaf van meststoffen en de toediening ervan lager.

De teeltkosten van gras en gras-rode klaver zijn nagenoeg gelijk (ZON-5).

Door de teelt van voederbieten op de helft van het maïsareaal (ZON-6) vallen de teeltkosten, de kosten voor het aanschaffen en toedienen van de meststoffen en de kosten voor bewaring en opslag hoger uit t.o.v. ZON-1.

De kosten voor de teelt van wintergerst op de helft van het snijmaïs areaal zijn vergelijkbaar met die van de teelt van snijmaïs, waardoor de verandering van de kosten in ZON-7 nihil is t.o.v. de referentie.

Tabel 7.3 Opbrengsten en kosten voor het referentiebedrijf en de veranderingen ten opzichte van de referentie voor de andere scenario's in $€ /$ bedrijf.



\section{Opbrengst minus kosten}

Uiteindelijk zijn de opbrengsten minus de kosten voor de scenario's ZON-4a en ZON-7 het meest afwijkend, in de orde van $€ 5000,-$, t.o.v. de referentie. In het geval dat er wintergerst wordt verbouwd op de helft van het snijmaïs areaal (ZON-7) is de opbrengst minus kosten lager. In het geval dat er beweid wordt (ZON-4a) is de opbrengst minus de kosten hoger. In de overige gevallen is de opbrengst minus de kosten tussen de $€ 1500$ en $€ 2500$,- hoger.

\subsubsection{Akkerbouw}

In Figuur 7.15 zijn de resultaten weergegeven van de economische bouwplanberekening voor het referentiebouwplan en de bouwplanvarianten op het akkerbouwbedrijf in Zuidoost Nederland. Doordat de alternatieve bouwplannen ZON-2, ZON-3, ZON-4(a), ZON-5 en ZON-6 dezelfde gewassen en aandelen bevat als het referentiebouwplan ZON-1 zijn er geen verschillen in het gemiddelde saldo. Vervanging van een deel van de snijmaïs door wintergerst (ZON-7) resulteert in een iets hoger saldo. 


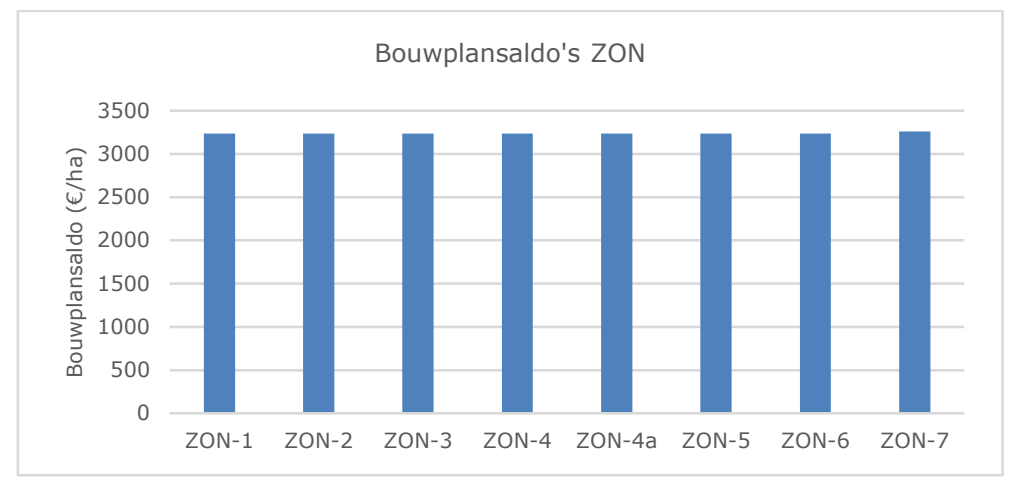

Figuur 7.15 Overzicht gemiddelde bouwplansaldo's Zuidoost Nederland.

\subsubsection{Nutriënten en organische stof}

In Figuur 7.16 is het $\mathrm{N}$ - en $\mathrm{P}_{2} \mathrm{O}_{5}$-bodemoverschot van de bouwplanscenario's weergegeven. Op het melkveebedrijf loopt het $\mathrm{N}$-bodemoverschot uiteen van 130 naar $170 \mathrm{~kg} \mathrm{~N}$ per ha, op het akkerbouwbedrijf van 84 naar $108 \mathrm{~kg} \mathrm{~N}$ per ha.

Verhoging van het aandeel blijvend grasland leidt tot een iets hoger N-overschot. Dit is een gevolg van de gestegen kunstmest-N-ruimte doordat er geen maïs meer wordt geteeld na gescheurd gras. Het telen van gras-rode klaver i.p.v. gras (ZON-5) geeft een lager overschot doordat er geen kunstmest meer wordt gebruikt op het gras. Deze daling van het kunstmestgebruik is hoger dan de ingerekende $\mathrm{N}$-binding door de rode klaver. De vervanging van snijmaïs door wintergerst (ZON-7) geeft zowel op het melkveebedrijf als akkerbouwbedrijf een stijging van het $\mathrm{N}$-overschot. Dit is een gevolg van een hogere $\mathrm{N}$-gebruiksnorm van wintergerst en een lagere $\mathrm{N}$-afvoer met geoogst product.

Het $\mathrm{P}_{2} \mathrm{O}_{5}$-bodemoverschot is op het melkveebedrijf bij alle bouwplanscenario's negatief m.u.v. het scenario waarin beweiding wordt toegepast ( $\mathrm{ZON}-4 a)$. Op het akkerbouwbedrijf is het $\mathrm{P}_{2} \mathrm{O}_{5}-$ bodemoverschot positief (5-7 kg $\mathrm{P}_{2} \mathrm{O}_{5}$ per ha). 


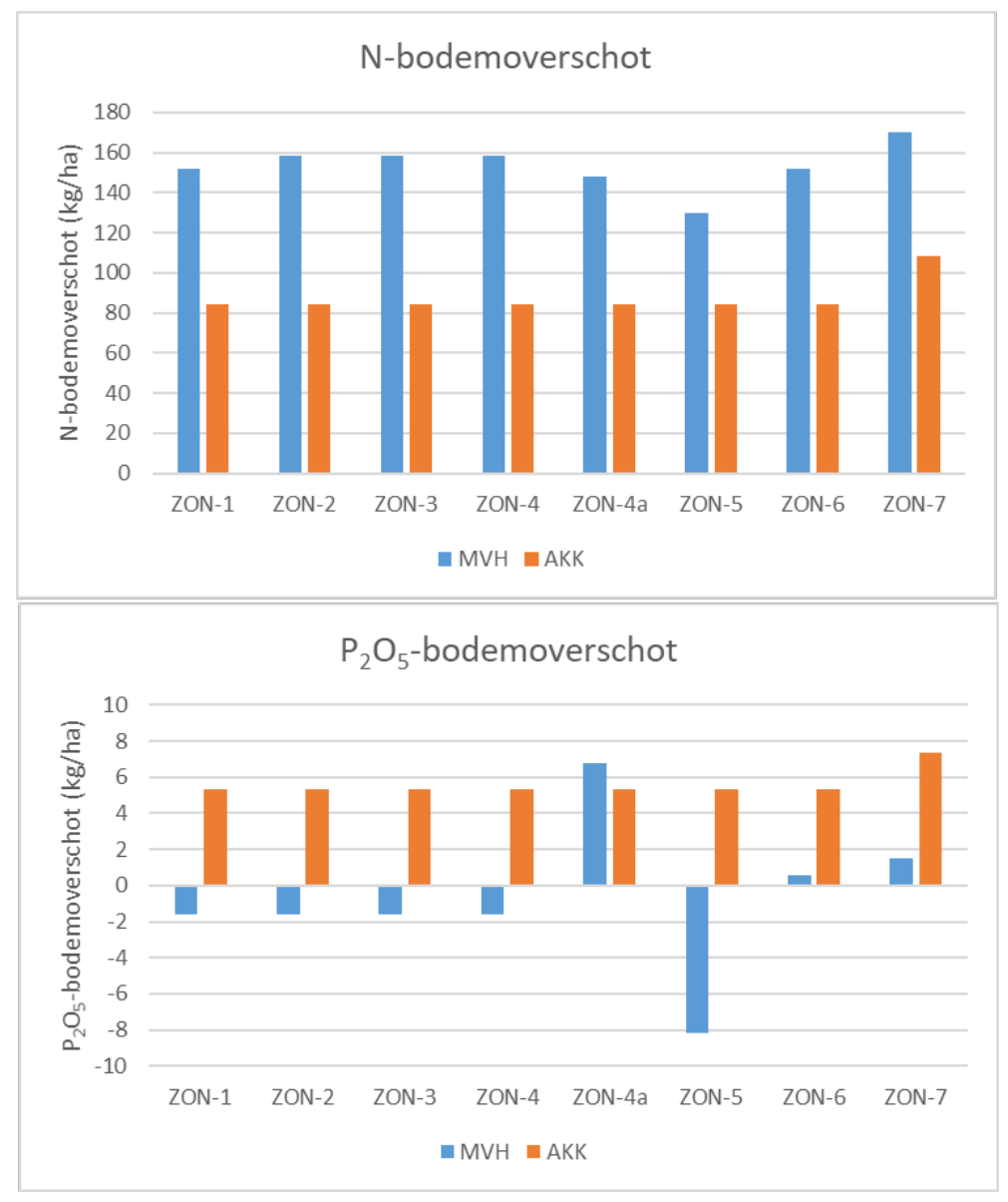

Figuur 7.16 Het $\mathrm{N}$ - en $\mathrm{P}_{2} \mathrm{O}_{5}$-bodemoverschot $(\mathrm{kg} / \mathrm{ha})$ van het melkvee- en akkerbouwbedrijf bij de verschillende bouwplanscenario's in Zuidoost-Nederland.

In Figuur 7.17 is de EOS-aanvoer weergegeven. Op het melkveebedrijf heeft de verhouding blijvend en tijdelijk grasland weinig effect op de EOS-aanvoer (vergelijk ZON $-1 \mathrm{t} / \mathrm{m} 4$ ). Vervanging van snijmaïs door wintergerst op het akkerbouwbedrijf (vergelijk ZON-8 met ZON-1) geeft een hogere EOS-aanvoer, doordat met wintergerst meer EOS wordt aangevoerd dan met snijmaïs. Bovendien is door het vroegere oogsttijdtip de ontwikkeling van de groenbemester, en daarmee de EOS-aanvoer, hoger.

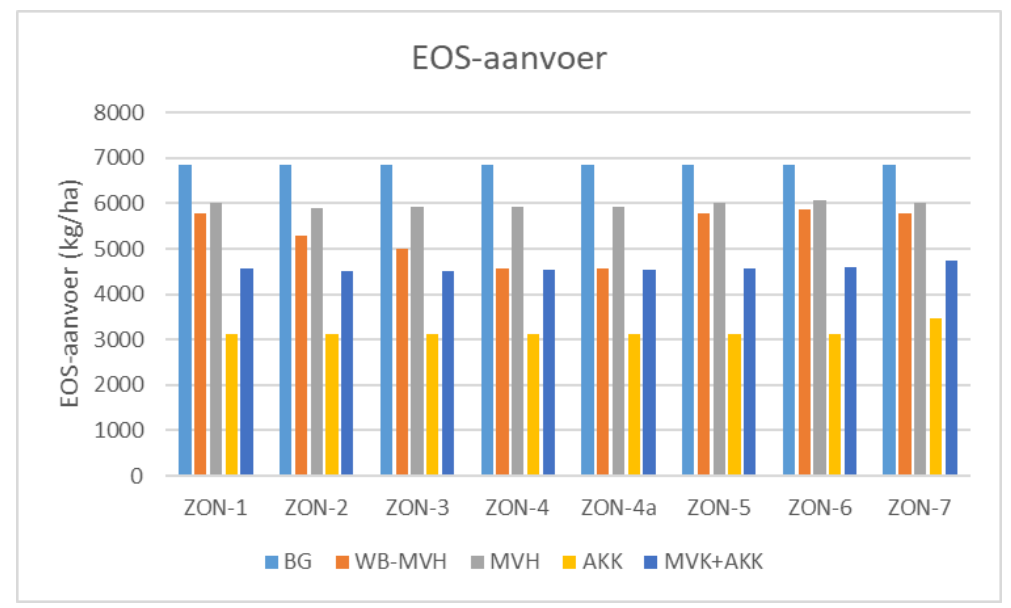

Figuur 7.17 De aanvoer van effectieve organische stof (EOS, $k g$ per ha) op de grond van het melkveebedrijf ( $B G=$ blijvend grasland, $W B=$ wisselbouw) en het akkerbouwbedrijf bij de verschillende bouwplanscenario's in Zuidoost-Nederland. 


\subsubsection{Broeikasgasemissies}

In Tabel 7.4 is voor de verschillende bouwplanvarianten het verschil in BKG-emissies met het referentiebouwplan weergegeven.

Verhoging van het aandeel blijvend grasland van 20\% (referentie) naar 40\% (ZON-2), 50\% (ZON-3) en $60 \%(Z O N-4)$ leidt niet tot grote veranderingen in BKG-emissies. In deze varianten vindt er geen beweiding plaats. In ZON-4a is dat wel het geval. In vergelijking met de situatie zonder beweiding dalen de BKG-emissies.

Vervanging van een deel van de maïs door voederbieten (ZON-6) of wintergerst (ZON-7) leidt tot een daling van de BKG-emissies, met name door minder aangekocht voer. Op het akkerbouwbedrijf zijn de BKG-emissies wat hoger als de maïs wordt vervangen door wintergerst

Tabel 7.4 Effect van de bouwplanaanpassingen in ZON op de hoeveelheid broeikasgasemissies ( $k g$ $\mathrm{CO}_{2}$-eq/ha) voor zowel het melkveebedrijf (MVH) als het akkerbouwbedrijf (AKK), uitgedrukt als verschil t.o.v. het referentiebouwplan.

\begin{tabular}{|c|c|c|c|c|c|c|c|}
\hline & ZON-2 & ZON-3 & ZON-4 & ZON-4a & ZON-5 & ZON-6 & ZON-7 \\
\hline \multicolumn{8}{|l|}{ MVH } \\
\hline $\mathrm{CO}_{2}$ & 20 & 22 & 24 & -983 & 761 & -911 & -909 \\
\hline $\mathrm{CH}_{4}$ & 0 & 0 & 0 & -33 & 649 & 186 & -106 \\
\hline Totaal & 40 & 35 & 30 & -743 & 1564 & -670 & -934 \\
\hline \multicolumn{8}{|l|}{ AKK } \\
\hline $\mathrm{CO}_{2}$ & & & & & & & 35 \\
\hline $\mathrm{N}_{2} \mathrm{O}$ & & & & & & & 119 \\
\hline Totaal & & & & & & & 154 \\
\hline
\end{tabular}

\subsubsection{Bodemgezondheid}

Bij het inpassen van aardappel in de rotatie (ZON-1 t/m ZON-7), zal een melkveehouder met andere nematoden rekening moeten houden dan bij afwisseling van alleen gras en maïs (Figuur 7.18;

Figuur 7.19). In een teelt van 1:8 zal aardappelmoeheid niet snel een probleem zijn, maar $M$. fallax, trichodoriden en tabaksratelvirus mogelijk wel. Deze kunnen door de teelt van Engels raaigras sterk in aantal toenemen.

Wanneer voederbiet op het melkveebedrijf wordt geteeld om de eiwitproductie te verhouden, moet rekening worden gehouden met schade door $D$. dipsaci en trichodoriden (ZON-6; Figuur 7.20). De cysteaaltjes $H$. betae en $H$. schachtii zullen in dit ruime bouwplan van 1:8 niet snel een probleem vormen. Pratylenchus penetrans zal mogelijk wel in aantal kunnen afnemen. In dit bouwplan zijn alle gewassen goede vermeerderaars van het quarantaineaaltje $M$. fallax. Daarnaast veroorzaken ritnaalden matige schade bij grassen, maar kunnen zware schade veroorzaken bij aardappel (Qiu et al., 2013). Vanwege de 4-jarige levenscyclus is er een risico op problemen met ritnaalden bij 3- of 4jarig grasland. 


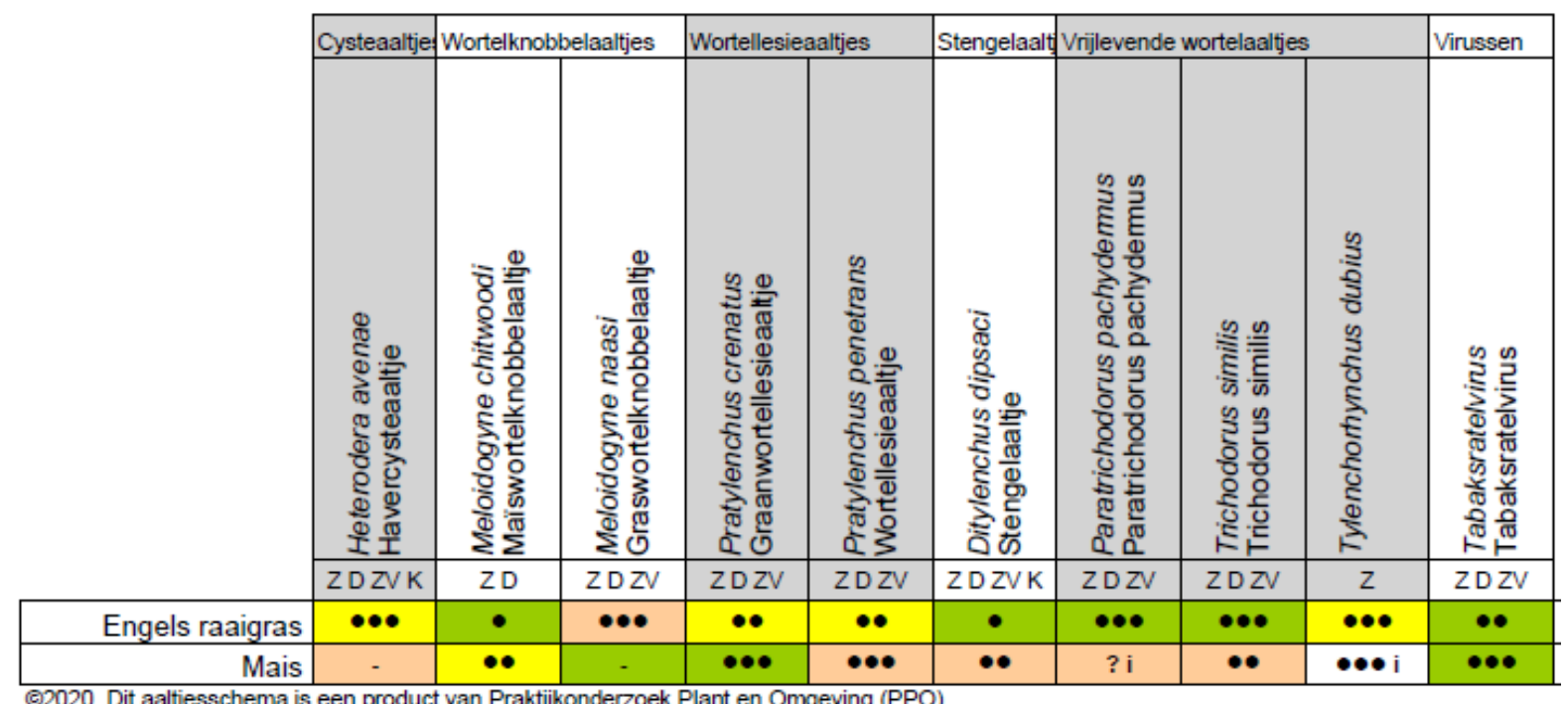

Figuur 7.18 Vermeerdering van en schade door nematoden in Zuidoost Nederland op een melkveebedrijf bij een huidige rotatie van Engels raaigras afgewisseld met maïs. Rotatie G-G-G-MA (uitgangssituatie).

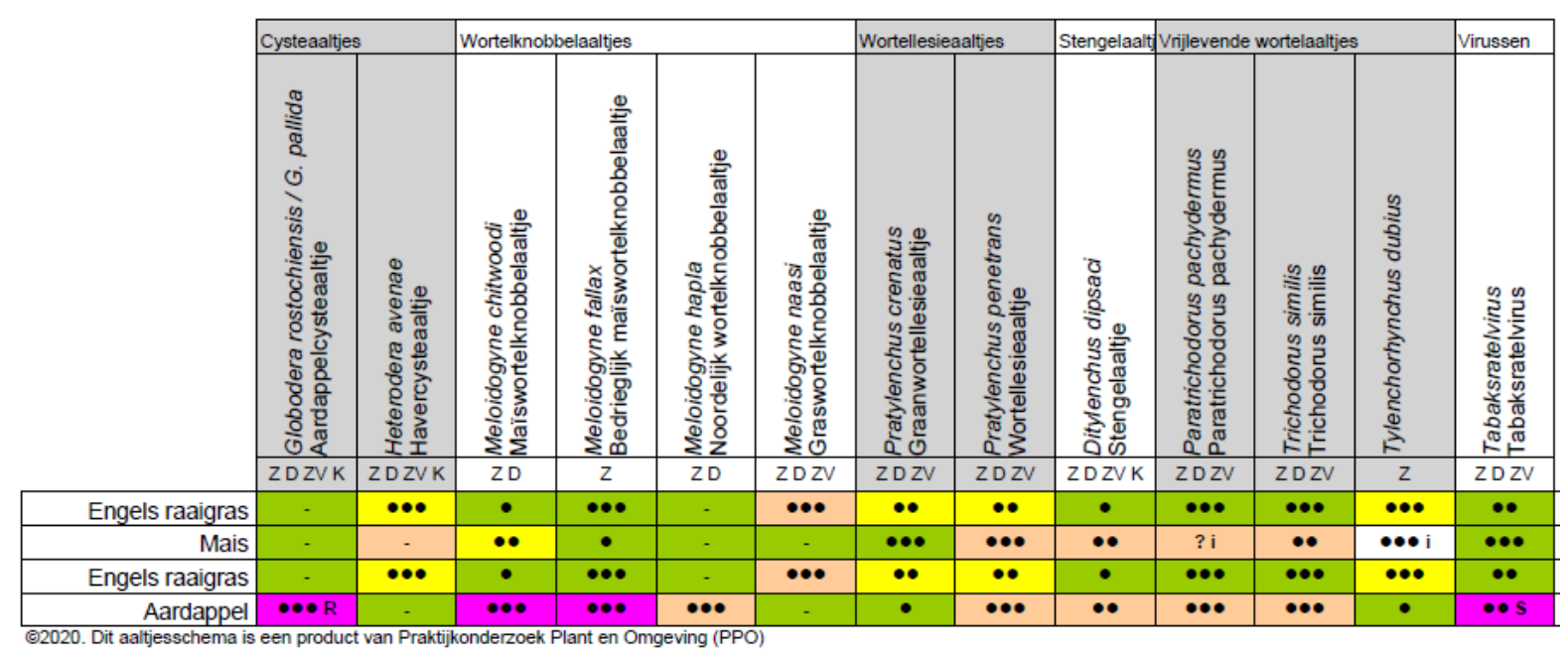

Figuur 7.19 Vermeerdering van en schade door nematoden in Zuidoost Nederland op een melkveebedrijf, waarin Engels raaigras wordt afgewisseld met maïs en, door samenwerking met een akkerbouwbedrijf, consumptieaardappel. Rotatie G-G-G-MA-G-G-G-CA (ZON-1, ZON-7).

Een mengsel van gras en rode klaver is een mogelijkheid om het eiwitgehalte te verhogen (ZON-5). Hierbij moet wel rekening worden gehouden met de aanwezige bodempathogenen en nematoden in een perceel. Ditylenchus dipsaci (stengelaaltjes) vermeerdert zich goed op rode klaver en brengt ernstige schade toe aan het gewas (Figuur 7.21). Er bestaan verschillende rassen van deze nematode, die verschillen in waardplantreeks en daarmee vermeerdering op verschillende gewassen. Waarschijnlijk vormen stengelaaltjes die zich vermeerderen op rode klaver geen risico voor de aardappelteelt en vermeerderen ze zich er ook niet op (Schomaker 2008). Omgekeerd kunnen stengelaaltjes die zich vermeerderen op aardappel zich waarschijnlijk niet vermeerderen op rode klaver, maar wel schade veroorzaken. Er is geen onderzoek gedaan naar de vermeerdering van $P$. penetrans op rode klaver. Deze nematode vermeerdert zich wel goed op veel andere klaversoorten en zou daarmee een risico kunnen vormen door de aardappelteelt. Ook de vermeerdering van wortelknobbelaaltjes op rode klaver is onbekend. Op witte klaver vermeerderen de wortelknobbelaaltjes M. chitwoodi, M. fallax en M. hapla zich, afhankelijk van het klaverras, matig tot slecht. Ook is geen onderzoek bekend over de vermeerdering van trichodoriden en tabaksratelvirus op rode klaver. Buitenlands onderzoek noemt wel grote verschillen in vermeerdering van D. dipsaci, 
Sclerotinia en andere bodemschimmels op verschillende rode klaverrassen (Pokorný et al., 2003; Lowe et al., 2014).

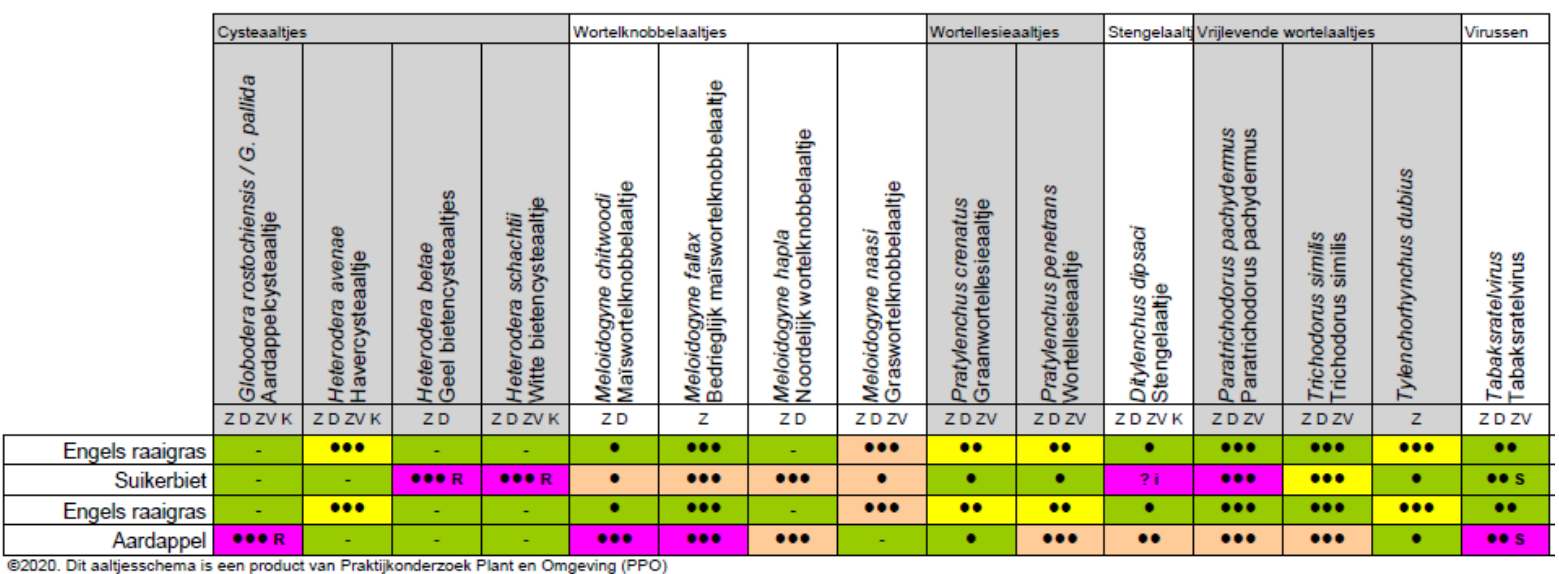

Figuur 7.20 Vermeerdering van en schade door nematoden in Zuidoost Nederland op een melkveebedrijf, waarin Engels raaigras wordt afgewisseld met voederbiet en, door samenwerking met een akkerbouwbedrijf, consumptieaardappel. Vanwege ontbreken van voederbiet in aaltjesschema is hier gekozen voor suikerbiet, met als kanttekening dat voederbiet minder is veredeld. Rotatie G-G-GVB-G-G-G-CA (ZON-6).

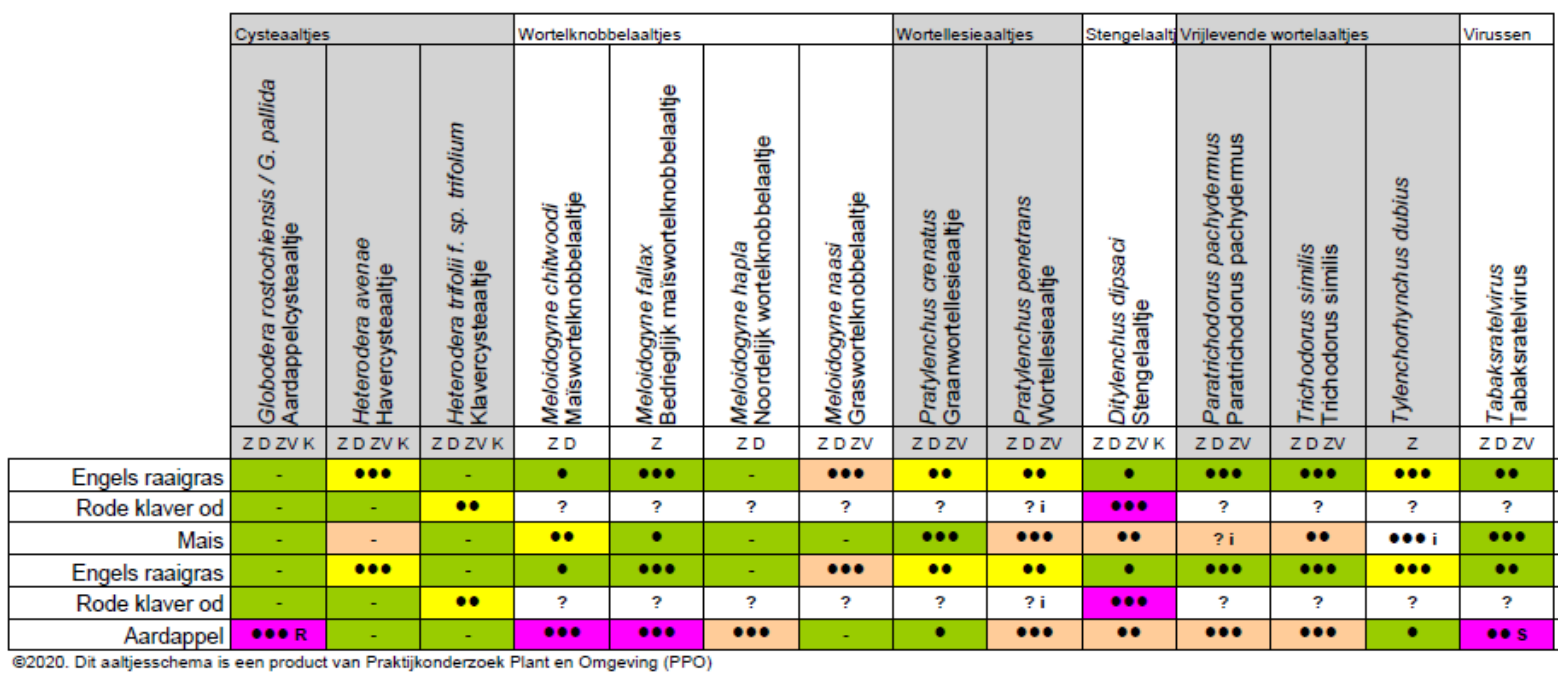

Figuur 7.21 Vermeerdering van en schade door nematoden in Zuidoost Nederland op een melkveebedrijf, waarin gras-klaver wordt afgewisseld met maïs en, door samenwerking met een akkerbouwbedrijf, consumptieaardappel. Rotatie GK-GK-GK-MA-GK-GK-GK-CA (ZON-5).

Op het akkerbouwbedrijf in het zuidoostelijk zandgebied is de rotatie ruim genoeg om resistente aardappel te kunnen telen zonder problemen met aardappelmoeheid (Figuur 7.22). De suikerbietenteelt is ruim genoeg om problemen met $H$. betae te voorkomen, omdat er geen andere waardplanten in het bouwplan zijn opgenomen. Er moet dan wel aandacht zijn voor het bestrijden van kruisbloemige en ganzevoetachtige onkruiden, die deze nematode ook kunnen vermeerderen. Wanneer suikerbieten met resistentie tegen $H$. schachtii worden geteeld, hoeft ook deze nematode geen probleem te zijn. Wel een probleem kunnen zijn M. chitwoodi, M. fallax, P. penetrans, D. dipsaci, trichodoriden en tabaksratelvirus.

Het bouwplan met wintergerst vergeleken met maïs levert vooral een verschil op in de vermeerdering van $P$. penetrans en $D$. dipsaci: hierin is wintergerst gunstiger met een lagere vermeerdering van beide nematodensoorten (Figuur 7.22; Figuur 7.23). Wat betreft de keuze van de groenbemester na maïs is het goed om rekening te houden met de aanwezige nematoden. Rogge en Italiaans raaigras 
vermeerderen M. chitwoodi sterk (Figuur 7.22). Dit is ongunstig voor de daaropvolgende peenteelt, al kan laat zaaien van peen de problemen met $M$. chitwoodi sterk verminderen. Beide raaigrassen vermeerderen $M$. fallax sterk, waarnaast Italiaans raaigras ook $P$. penetrans sterk vermeerdert

(Figuur 7.22). Een zomerteelt van Tagetes patula kan een besmetting met $P$. penetrans nagenoeg saneren, waarmee ruimte komt om aandacht te schenken aan het beheersen van andere nematoden.

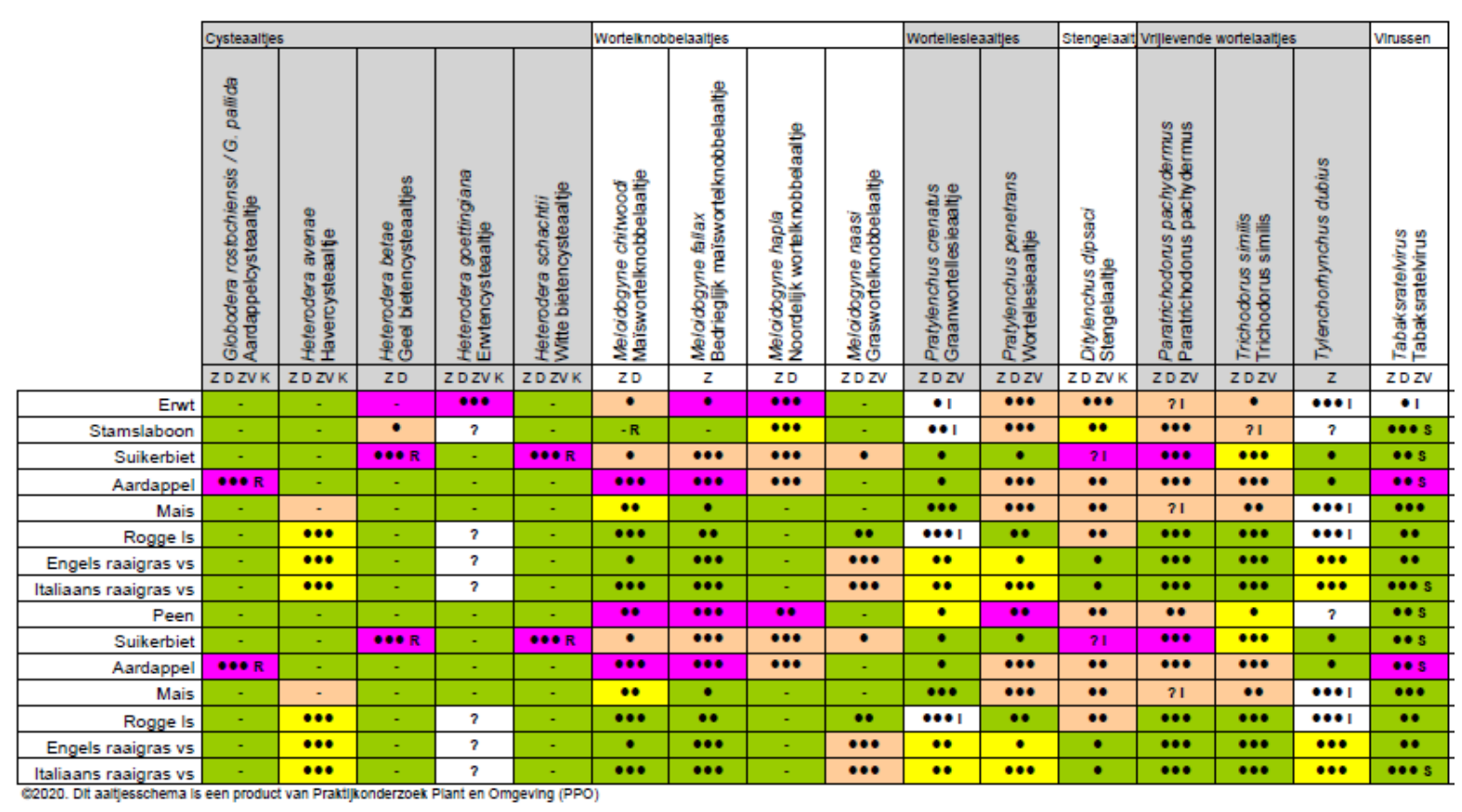

Figuur 7.22 Vermeerdering van en schade door nematoden in Zuidoost Nederland op een akkerbouwbedrijf met aardappelteelt 1:4. Als groenbemester na maïs wordt een keuze gemaakt uit rogge of Engels of Italiaans raaigras. Rotatie ER+BO-SB-CA-MA-Groenbemester-PE-SB-CA-MAGroenbemester (uitgangssituatie en ZON-1 t/m ZON-6).

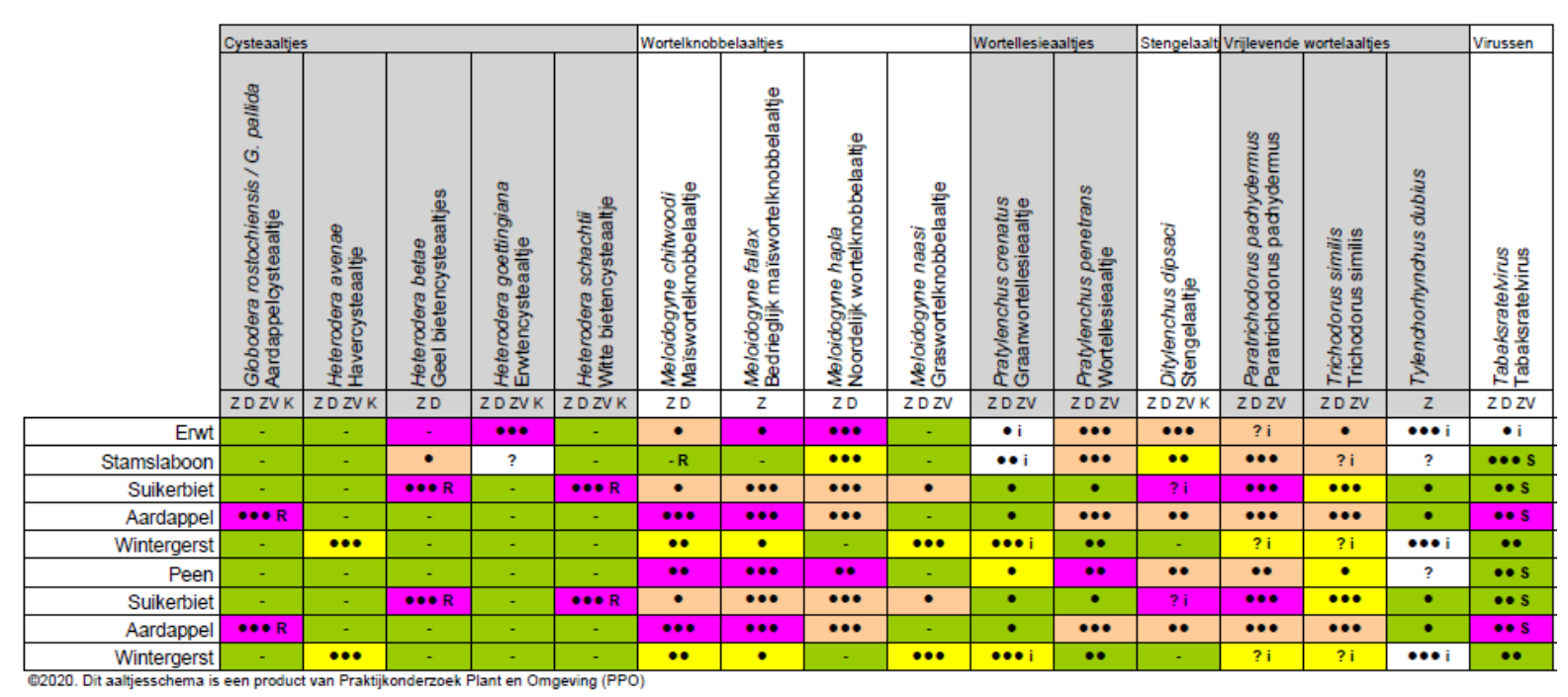

Figuur 7.23 Vermeerdering van en schade door nematoden in Zuidoost Nederland op een akkerbouwbedrijf, waarbij de maïsteelt met groenbemester is vervangen door wintergerst. Rotatie $E R+B O-S B-C A-W G-P E-S B-C A-W G(Z O N-7)$. 


\subsection{Centraal-Nederland (CEN)}

\subsubsection{Economie}

\subsubsection{Melkveehouderij}

\section{Voederwaarde opbrengst}

In deze studie is de opbrengst voor tijdelijk en blijvend grasland gelijk gehouden. Hierdoor is de voederwaarde opbrengst voor CEN-1 en CEN-2, hoewel ze verschillen in het aandeel blijvend en tijdelijk grasland, hetzelfde; respectievelijk 667 ton droge stof, 620902 kVEM, 89269 kg RE en 38904 kg DVE (Figuur 7.24).

Wanneer het tijdelijke grasland werd vervangen door gras-rode klaver stegen de droge stof en ruw eiwit opbrengst naar respectievelijk 706 ton en 93553 kg RE. Terwijl de kVEM- en DVE opbrengst daalden naar respectievelijk 574469 kVEM en 35088 kg DVE (Figuur 7.24).
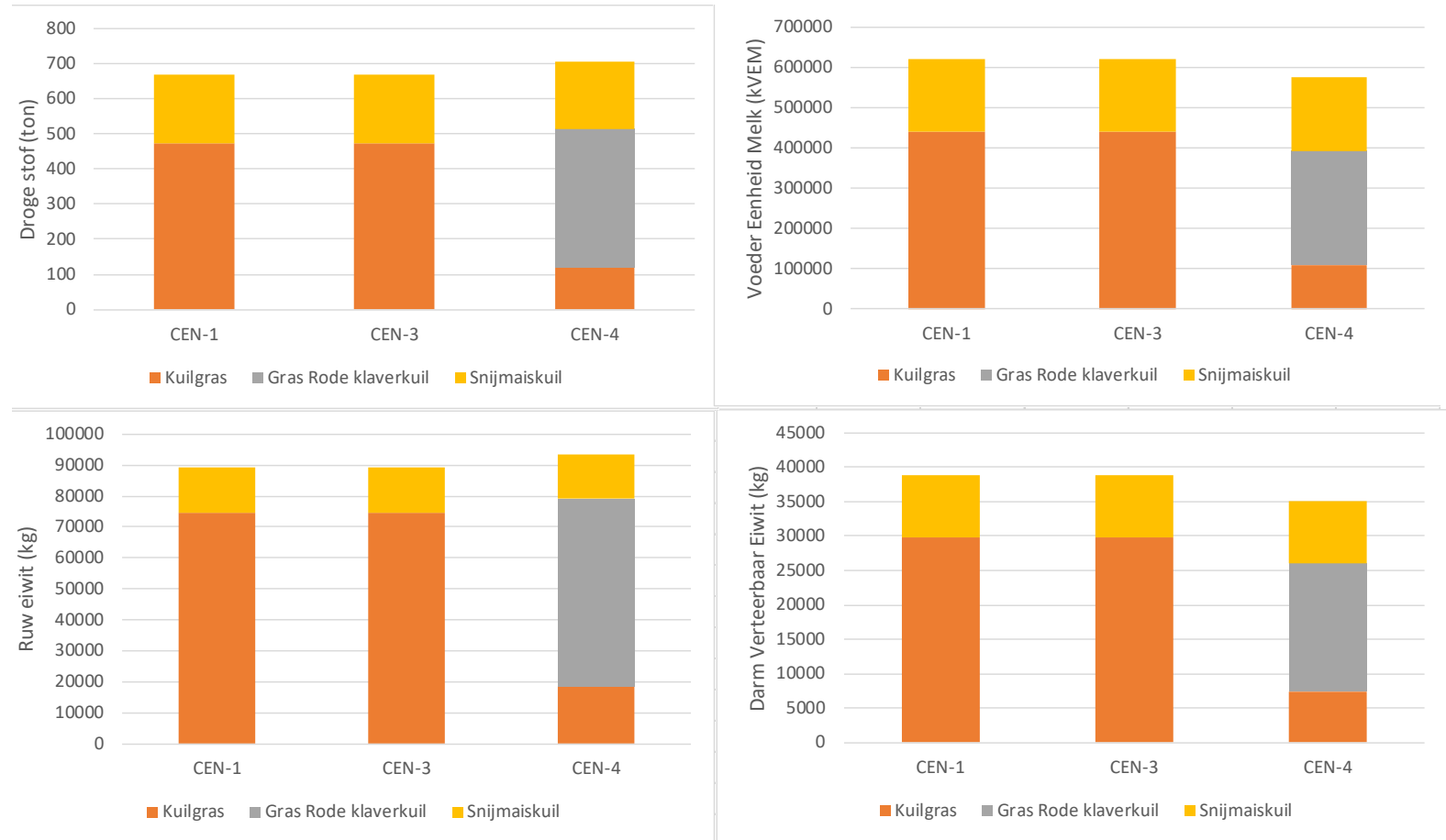

Figuur 7.24 Droge stof, kVEM, ruw eiwit en DVE opbrengst voedergewassen die op naam van het melkveehouderij bedrijf worden verbouwd in de scenario's CEN-1, CEN-3 en CEN-4.

Een maat voor de hoeveelheid melk die een koe kan geven uit de beschikbare droge stof is de VEMDVE verhouding per eenheid VW. Figuur 7.25 laat de VEM-DVE verhouding per eenheid VW voor de geteelde droge stof en de gevoerde droge stof zien.

De VEM-DVE verhouding per eenheid VW is voor CEN-4 in de gevoerde droge stof lager dan voor CEN1 en CEN-3. Echter het verschil in VEM-DVE verhouding per eenheid VW tussen de geteelde en gevoerde droge stof is voor CEN-4 kleiner.

Bijlage 5 en Bijlage 6 geven inzicht in de gevoerde en geteelde producten. 


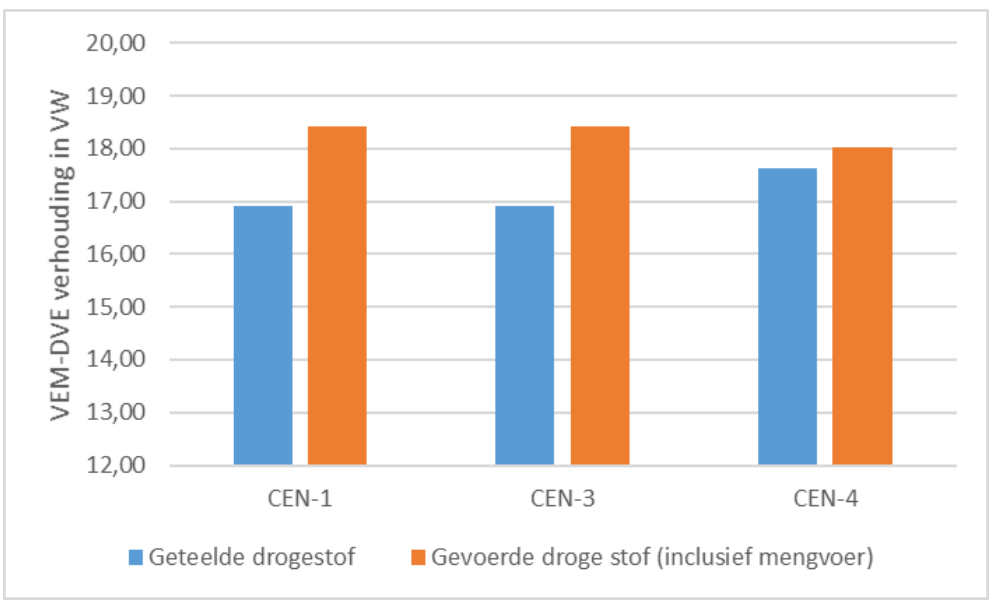

Figuur 7.25 VEM/DVE verhouding van respectievelijk de geteelde en gevoerde droge stof in de scenario's CEN-1, CEN-3 en CEN-4.

\section{Melkproductie}

Voor de scenario's CEN-1, CEN-3 En CEN-4 was het niet mogelijk om het niveau van de melkproductie te halen met het aantal dieren (jongvee en melkkoeien) zoals geformuleerd bij de bedrijfsopzet (Bijlage 8-Tabel 6.1). Dit werd veroorzaakt doordat er in de rantsoenberekeningen voor gekozen is om geen bijproducten in het rantsoen op te nemen, maar het ruwvoer alleen aan te vullen met mengvoer.

De melkproductie voor CEN-1 en CEN-3 was gelijk, terwijl de melkproductie voor CEN-4 iets lager lag zoals de inkomsten uit melkgeld laten zien (Tabel 7.5).

\section{Aan- en verkoop voer}

Tabel 7.5 laat zien dat er voor CEN-1 €27.407,- voer verkocht is. Dit betreft het overschot aan kuilgras dat op deze wijze in de studie op waarde is gezet. Anderzijds wordt er $€ 75.442$,- aan voedermiddelen aangekocht. Dit betreft de aankoop van mengvoer.

Voor CEN-3, waar het gras en maïsaandeel in het bouwplan hetzelfde zijn als in CEN-1, verandert de aan- en verkoop van voedermiddelen niet.

In het scenario waarin het tijdelijke grasland is vervangen gras-rode klaver (CEN-4) zijn de inkomsten uit voerverkopen $€ 5681$,- hoger t.o.v. de referentie (CEN-1).

De aankoop van voedermiddelen is voor alle scenario's gelijk, omdat hetzelfde rantsoen gevoerd wordt.

Bijlage 7 geeft een overzicht van de hoeveelheden droge stof die met diverse producten zijn aangekocht en verkocht.

\section{Teelt, bemesting en voeropslag}

Hoewel er in voederwaarde opbrengst geen verschillen waren tussen de scenario's waarin alleen het aandeel blijvend en tijdelijk grasland varieerde (CEN-1 en CEN-3), waren er grote verschillen in de kosten van de teelt van het gras en met name de post "Herinzaai tijdelijk en blijvend grasland" (Tabel 7.5).

Wanneer het aandeel éénjarig grasland (25\% van het grasland areaal) werd omgezet naar blijvend grasland (CEN-3), daalden de herinzaaikosten met $€$ 7890,-. De overige kosten bleven gelijk.

Wanneer het tijdelijke grasland werd vervangen door gras-rode klaver (CEN-4) waren de kosten voor herinzaai en de teelt vergelijkbaar, maar waren met name de kosten voor de aankoop van meststoffen lager t.o.v. de referentie (Tabel 7.5). De kosten voor de aankoop van meststoffen zijn lager, omdat er geen kunstmest stikstof hoeft te worden toegediend bij de teelt van gras-rode klaver. 


\section{Opbrengst minus kosten}

Uiteindelijk zijn de opbrengsten minus de kosten voor zowel het scenario waar het aandeel blijvend grasland wordt verhoogd (CEN-3) als het scenario waar het tijdelijke grasland wordt vervangen door gras-rode klaver (CEN-4) hoger t.o.v. de referentie.

Tabel 7.5 Opbrengsten en kosten voor het referentie bedrijf en de veranderingen ten opzichte van de referentie voor de andere scenario's in $€ /$ bedrijf.

\begin{tabular}{|c|c|c|c|}
\hline Post / Regio & Kosten & $\Delta$ kosten t.o.v. CEN-1 & \\
\hline Inkomsten uit melkgeld & 350758 & 0 & -5754 \\
\hline Opbrengst totaal & 378165 & 0 & -5754 \\
\hline Herinzaai tijdelijk en blijvend grasland & 18411 & -7890 & -17534 \\
\hline Herinzaai gras/rode klaver & 0 & 0 & 18854 \\
\hline Teelst gras/rode klaver & 0 & 0 & 29436 \\
\hline Teelt gras & 44154 & 0 & -33116 \\
\hline Toediening meststoffen ${ }^{2}$ & 16420 & 0 & 1551 \\
\hline Opslag en bewaring ruwvoer ${ }^{3}$ & 10946 & 0 & 1984 \\
\hline Kosten totaal & 188729 & -7890 & -5535 \\
\hline Opbrengst minus kosten & 189436 & 7890 & -218 \\
\hline $\begin{array}{l}\text { Opbrengst minus kosten exclusief inkomsten } \\
\text { uit voerverkoop }\end{array}$ & 162029 & 7890 & -218 \\
\hline
\end{tabular}

\subsubsection{Akkerbouw}

In Figuur 7.26 zijn de resultaten weergegeven van de economische bouwplanberekening voor het referentiebouwplan en de bouwplanvarianten op het akkerbouwbedrijf in Centraal-Nederland. Zoals aangegeven bij de beschrijving van de bouwplannen zijn is bij de akkerbouwberekeningen uitgegaan van twee referenties, eentje met gezamenlijk grondgebruik (CEN-1) en eentje zonder samenwerking (CEN-2). Vergelijking van deze twee varianten laat zien dat samenwerking een hoger saldo geeft door een verhoogd aandeel van pootaardappelen in vergelijking met de variant zonder samenwerking. Voor de situatie zonder samenwerking is nagegaan wat het gevolg is van vervanging van een deel van de wintertarwe door respectievelijk droge erwten, soja en veldbonen (CEN-5 t/m 7). Het saldo daalt hierdoor met $€ 70-135$ per ha, waarbij het resultaat voor veldbonen het minst ongunstig is. Voor de oogst van de zaadleguminosen is ervan uit gegaan dat deze worden gedorst met een reeds aanwezige combine op het akkerbouwbedrijf.

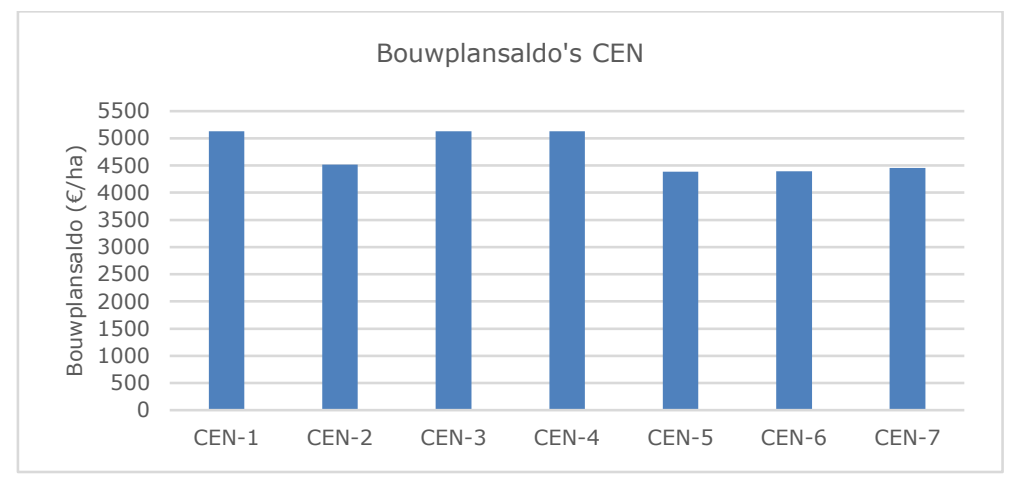

Figuur 7.26 Overzicht gemiddelde bouwplansaldo's Centraal-Nederland. 


\subsubsection{Nutriënten en organische stof}

Bij de grondruilvarianten (CEN-1, CEN-3 en CEN-4) varieert het N-bodemoverschot tussen 173 en 185 $\mathrm{kg} \mathrm{N}$ per ha op het melkveebedrijf, op akkerbouwbedrijf bedraagt het overschot bij alle drie scenario's $64 \mathrm{~kg} \mathrm{~N}$ per ha (Figuur 7.27). Vervanging van het tijdelijke grasland door gras-rode klaver (vergelijk CEN-3 met CEN-1) leidt tot een daling van het $\mathrm{N}$-overschot, dat een gevolg is van een lager kunstmestgebruik en een hogere afvoer met geoogst product.

Het $\mathrm{P}_{2} \mathrm{O}_{5}$-overschot is op het melkveebedrijf negatief en loopt uiteen van -4 tot $-10 \mathrm{~kg} \mathrm{P}_{2} \mathrm{O}_{5}$ per ha. De vervanging van gras door gras-rode klaver geeft een negatiever overschot door een hogere gewasafvoer. Op het akkerbedrijf is het $\mathrm{P}_{2} \mathrm{O}_{5}$-overschot positief en bedraagt circa $15 \mathrm{~kg} \mathrm{P}_{2} \mathrm{O}_{5}$ per ha.

De vervanging van wintertarwe door erwten, soja en veldbonen leidt tot een lager N-overschot, maar bij de varianten waarbij de tarwe is vervangen door erwten en soja ( $C E N-5$ en CEN-6) een hoger $\mathrm{P}_{2} \mathrm{O}_{5}-$ overschot. Dit komt door de lagere gewasafvoer in vergelijking met wintertarwe en veldbonen.

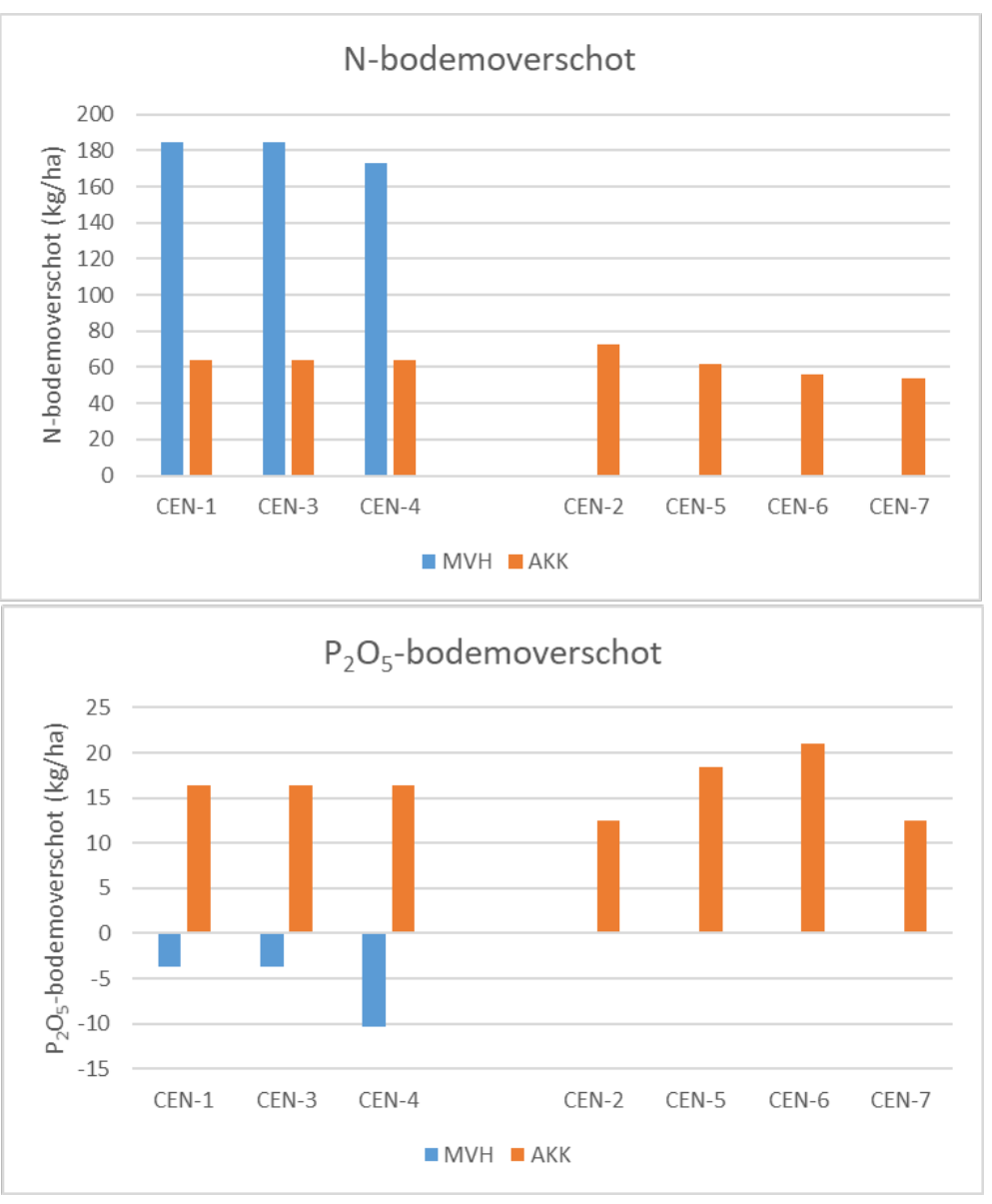

Figuur 7.27 Het $\mathrm{N}$ - en $\mathrm{P}_{2} \mathrm{O}_{5}$-bodemoverschot ( $\mathrm{kg} / \mathrm{ha}$ ) van het melkvee- en akkerbouwbedrijf bij de verschillende bouwplanscenario's in Centraal-Nederland.

In Figuur 7.28 is de EOS-aanvoer weergegeven. Bij variant CEN-3, waarbij niet gras maar maïs op het akkerbouwbedrijf (en op het bollenbedrijf) wordt geteeld, stijgt de EOS-aanvoer op het melkveebedrijf en daalt deze op het akkerbouwbedrijf. Dat komt omdat met maïs veel minder EOS wordt aangevoerd dan met gras. Op systeemniveau is de EOS-aanvoer ook wat hoger dan bij CEN-1. Dat komt, omdat er nu meer gras binnen het systeem wordt geteeld, terwijl deze bij CEN-1 deels ook buiten het systeem (op het bollenbedrijf) wordt geteeld.

De vervanging van wintertarwe door vlinderbloemige gewassen leidt bij erwten en veldbonen niet tot grote verschillen in EOS-aanvoer. Bij soja is deze circa $200 \mathrm{~kg}$ per ha lager, dit is vooral het gevolg 
van het feit dat door de relatief late oogst van soja er geen ruimte meer is voor een goed ontwikkelde groenbemester.

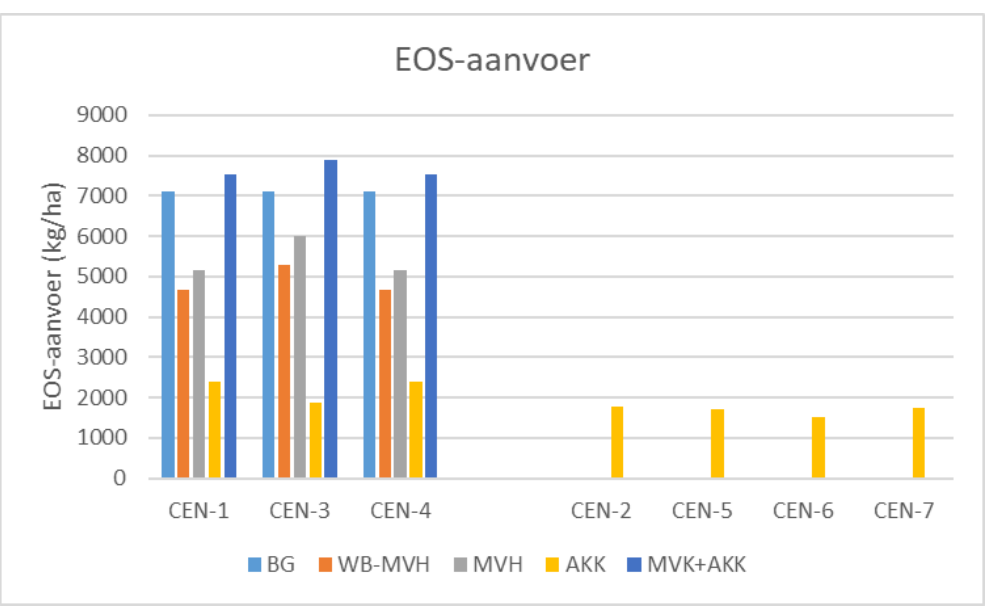

Figuur 7.28 De aanvoer van effectieve organische stof (EOS, $\mathrm{kg}$ per ha) op de grond van het melkveebedrijf ( $B G$ = blijvend grasland, $W B=$ wisselbouw) en het akkerbouwbedrijf bij de verschillende bouwplanscenario's in Centraal-Nederland.

\subsubsection{Broeikasgasemissies}

In Tabel 7.6 is voor de verschillende bouwplanvarianten het verschil in BKG-emissies met het referentiebouwplan weergegeven. Verhoging van het areaal blijvend grasland op het melkveebedrijf (CEN-3) geeft iets lagere BKG-emissies. Vervanging van het tijdelijke grasland door gras-rode klaver (CEN-4) leidt tot lagere BKG-emissies. Dit is vooral een gevolg van een lager kunstmest-N-gebruik.

Voor het akkerbouwbedrijf is gekeken naar vervanging van wintertarwe door zaadleguminosen: erwten (CEN-5) en veldboon (CEN-7). Deze bouwplanvarianten zijn vergeleken met een situatie zonder samenwerking (CEN-2). De BKG-emissies dalen wanneer de tarwe wordt vervangen door de genoemde zaadleguminosen, hoewel het effect op bouwplanniveau beperkt is.

Tabel 7.6 Effect van de bouwplanaanpassingen in CEN op de hoeveelheid broeikasgasemissies ( $k g$ $\mathrm{CO}_{2}$-eq/ha) voor zowel het melkveebedrijf (MVH) als het akkerbouwbedrijf (AKK), uitgedrukt als verschil t.o.v. het referentiebouwplan (CEN-1).

\begin{tabular}{|c|c|c|c|c|c|}
\hline & CEN-2 & CEN-3 & CEN-4 & CEN-5 & CEN-7 \\
\hline \multicolumn{6}{|l|}{ MVH } \\
\hline $\mathrm{CO}_{2}$ & & -32 & -694 & & \\
\hline $\mathrm{CH}_{4}$ & & 0 & 55 & & \\
\hline Totaal & & -46 & -400 & & \\
\hline \multicolumn{6}{|l|}{ AKK } \\
\hline $\mathrm{CO}_{2}$ & 107 & & & -95 & -74 \\
\hline $\mathrm{N}_{2} \mathrm{O}$ & 81 & & & 33 & -5 \\
\hline Totaal & 189 & & & -61 & -79 \\
\hline
\end{tabular}

\subsubsection{Bodemgezondheid}

In dit gebied is gekozen om de aandacht alleen te richten op de kleigebieden, al komen in het Centraal zeekleigebied ook lichtere gronden voor. Op zwaardere gronden met een afslibbaarheid van $30 \%$ of

88 | Rapport WPR-1062 
hoger is er een beperkt aantal aaltjessoorten dat problemen kan veroorzaken. Dit zijn voornamelijk cysteaaltjes (Globodera en Heterodera) en stengelaaltjes (Ditylenchus dipsaci). Op lichtere gronden zal daarnaast ook rekening gehouden moeten worden met mogelijk voorkomen van wortelknobbelaaltjes (Meloidogyne), wortellesieaaltjes (Pratylenchus), vrijlevende aaltjes (Tylenchorhynchus en Paratrichodorus teres) en tabaksratelvirus. Deze problemen zijn vergelijkbaar met die in het Noordoostelijk zand- en dalgebied (7.1.4) en in het Zuidoostelijk zandgebied (7.2.4) en zijn daar beschreven, al komen daar andere trichodoridesoorten met iets andere waardplanten voor.

Op een melkveebedrijf met alleen Engels raaigras afgewisseld met maïs, zal Heterodera avenae kunnen vermeerderen op Engels raaigras en mogelijk voor matige schade in maïs zorgen (Figuur 7.29). Wanneer daarnaast, door samenwerking met een akkerbouwer, ook aardappel en tulp in het bouwplan worden opgenomen, moet rekening worden gehouden met aanwezigheid van aardappelcyste- en stengelaaltjes (CEN-1; Figuur 7.29). In de ruime opzet van dit bouwplan (1:8 aardappel) zullen aardappelcysteaaltjes geen groot probleem vormen voor de aardappelteelt, al zullen de aantallen bij het telen van vatbare rassen licht kunnen toenemen en de nematoden zich over het veld kunnen verspreiden. In dat geval zal de kans op detectie van aardappelcysteaaltjes bij de verplichte grondbemonstering toenemen. Bij aanwezigheid van stengelaaltjes kunnen er wel problemen optreden, aangezien tulp zeer gevoelig is voor schade en de nematoden lange tijd in de bodem kunnen overleven. Het is nog niet duidelijk of opnemen van maïs en aardappel in het bouwplan een risico vormt voor schade door stengelaaltjes in de tulpenteelt. Er bestaan verscheidene rassen stengelaaltjes, die visueel niet van elkaar te onderscheiden zijn. De waardplantreeks van deze stengelaaltjesrassen verschilt, maar de informatie hier over is te beperkt om aan te kunnen geven of een ras dat zich op maïs of aardappel vermeerdert ook schade zal opleveren in tulp. Wanneer de maïsteelt op het melkveebedrijf vervalt, intensiveert de aardappelteelt van 1:8 naar 1:6 (CEN-2). Dit kan problemen geven met aardappelmoeheid bij de teelt van vatbare, maar niet van resistente aardappelrassen (Figuur 7.30).

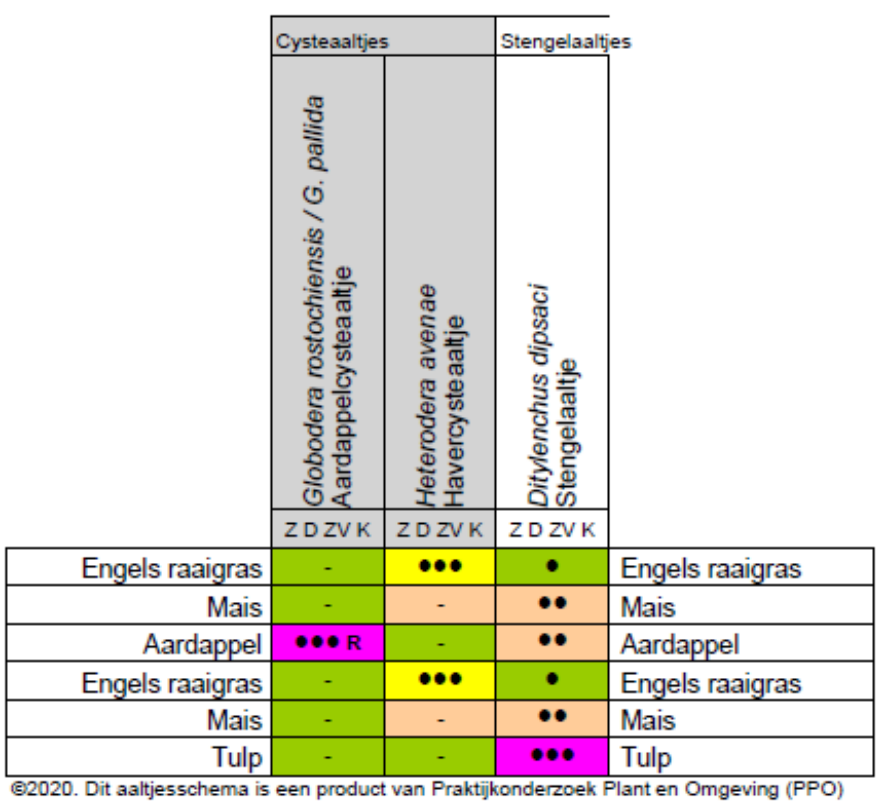

Figuur 7.29 Vermeerdering van en schade door nematoden in het Centraal kleigebied op een melkveebedrijf in de huidige situatie zonder (eerste twee rijen: rotatie G-G-G-MA-G-G-G-MA; uitgangssituatie) of met samenwerking met een akkerbouwbedrijf (rotatie G-G-MA-PA-G-G-MA-TU; CEN-1). 


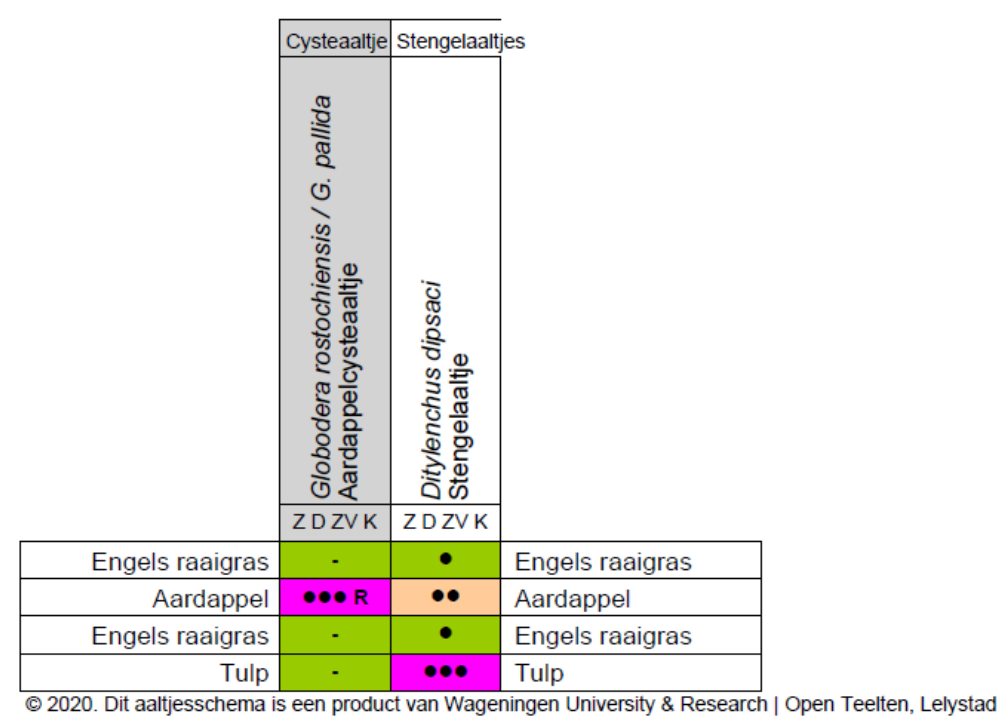

Figuur 7.30 Vermeerdering van en schade door nematoden in het Centraal kleigebied op een melkveebedrijf bij gezamenlijk grondgebruik met een akkerbouwbedrijf (rotatie G-G-PA-G-G-TU; CEN2).

Een melkveebedrijf kan de eiwitproductie verhogen door het zaaien van grasklaver in plaats van gras (CEN-3). Rode klaver vermeerdert $D$. dipsaci goed en ondervindt hier schade van, al is dit wel afhankelijk van het stengelaaltjesras (Figuur 7.31). Waarschijnlijk vormen stengelaaltjes die zich vermeerderen op rode klaver geen risico voor de aardappelteelt en vermeerderen ze zich er ook niet op (Schomaker, 2008). Omgekeerd kunnen stengelaaltjes die zich vermeerderen op aardappel zich waarschijnlijk niet vermeerderen op rode klaver, maar er wel schade in veroorzaken. Er is geen informatie over de vermeerdering en schade van stengelaaltjes uit rode klaver op tulp en omgekeerd.

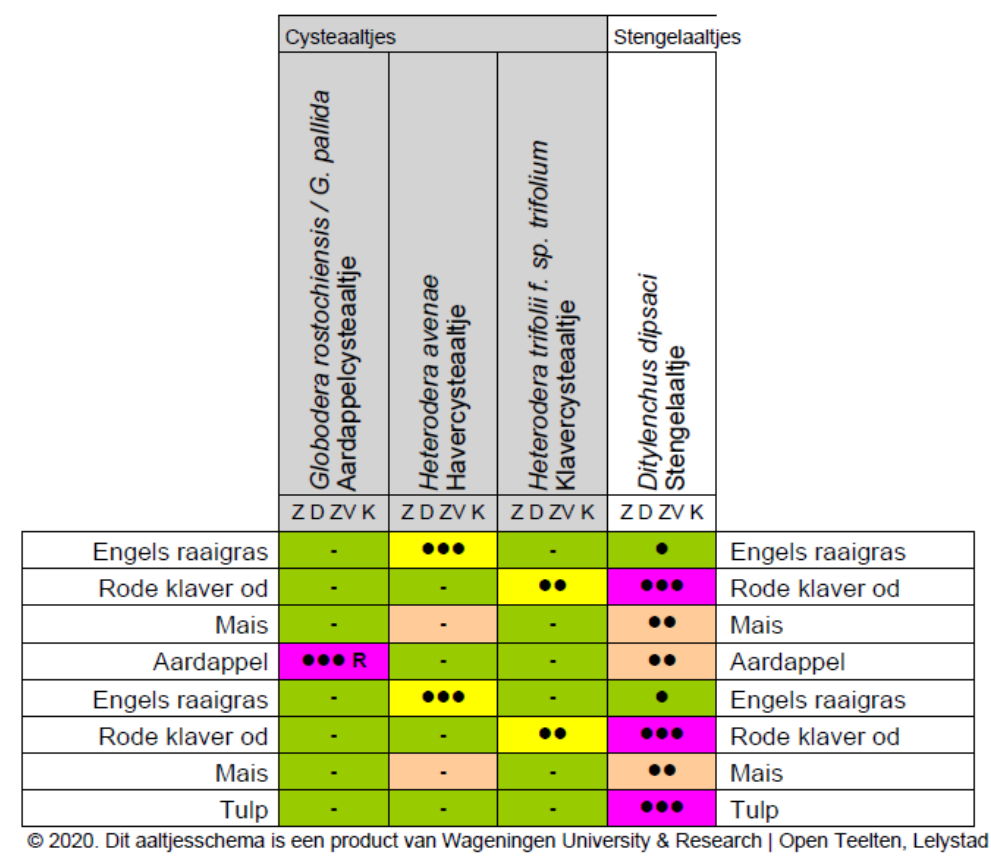

Figuur 7.31 Vermeerdering van en schade door nematoden in het Centraal kleigebied op een melkveebedrijf bij samenwerking met een akkerbouwbedrijf, waarbij ter verhoging van de eiwitproductie gras wordt vervangen door grasklaver (rotatie GK-GK-MA-PA-GK-GK-MA-TU; CEN-3).

In de huidige rotatie op een akkerbouwbedrijf in het Centraal Kleigebied worden pootaardappels geteeld in een rotatie van 1:3. Bij aanwezigheid van aardappelcysteaaltjes is deze teelt te intensief om 
zonder problemen vatbare pootaardappels te kunnen telen (Figuur 7.32). De teelt van resistente aardappels is dan wel mogelijk, al zal rekening gehouden moeten worden met zowel de soort cysteaaltjes als de populatie. Tegen G. rostochiensis zijn volledig resistente rassen beschikbaar, maar tegen G. pallida alleen partieel resistente rassen, die werkzaam zijn tegen verschillende populaties. Met een goede grondbemonstering en het programma Nemadecide is te bepalen van welk aardappelras de teelt mogelijk is. Voor de teelt van suikerbiet is het belangrijk om de aanwezigheid van $H$. schachtii te bepalen. Bij een teelt van 1:5 is de schade bij teelt van een vatbaar ras doorgaans beperkt. Naast suikerbiet kan $H$. schachtii zich ook vermeerderen op bladrammenas, tenzij wordt gekozen voor een resistent ras. Met een zomerteelt van een resistent bladrammenasras kan een besmetting actief worden verlaagd, maar dat is alleen effectief in een warme zomer. Stengelaaltjes die zich vermeerderen in ui en aardappel kunnen waarschijnlijk ook problemen veroorzaken in de teelt van suikerbiet en peen.

Wanneer een akkerbouwbedrijf een samenwerking aangaat met een melkveebedrijf, kan worden besloten een deel van het areaal wintertarwe te bestemmen voor maïs (CEN-2; Figuur 7.33). Maïs vermeerdert $D$. dipsaci sterker dan wintertarwe, maar er is geen informatie bekend over de waardplantstatus ten opzichte van verschillende stengelaaltjesrassen. Wanneer een deel van de wintertarwe wordt vervangen door Engels raaigras, betekent dit op kleigrond geen verschil voor het risico op problemen met nematoden (CEN-1; Figuur 7.33). Opnemen van grasklaver in het bouwplan van een akkerbouwbedrijf vormt echter wel een risico voor de peenteelt (CEN-3; Figuur 7.33). Stengelaaltjes uit rode klaver veroorzaken waarschijnlijk geen schade in de teelt van aardappel, ui en suikerbiet, maar wel in de teelt van peen. Het is verstandig om gekeurd zaaizaad te gebruiken om risico op besmetting te verkleinen.

Opnemen van erwt (CEN-4) of veldboon (CEN-5) in plaats van wintertarwe kan op kleigrond problemen met stengelaaltjes vergroten (Figuur 7.34). Stengelaaltjes uit ui en aardappel vermeerderen zich goed op beide gewassen en veroorzaken matige schade op beide planten, maar vertonen geen duidelijke symptomen. Door de goede vermeerdering vormen ze wel een extra risico voor de teelt van ui en wellicht suikerbiet. Problemen met erwtecysteaaltjes zijn ongebruikelijk en vormen geen risico voor andere gewassen dan vlinderbloemigen (Figuur 7.34). Soja is niet opgenomen in aaltjesschema, maar het is aannemelijk dat deze soort eenzelfde beeld zal vertonen als veel andere vlinderbloemigen (CEN-6). Wat betreft schimmelziekten, vermeerdert soja Fusarium solani, Pythium-soorten en Sclerotinia sclerotiorum (rattenkeutelziekte) sterk en ondervindt sterke schade van de laatste (Best4Soil).

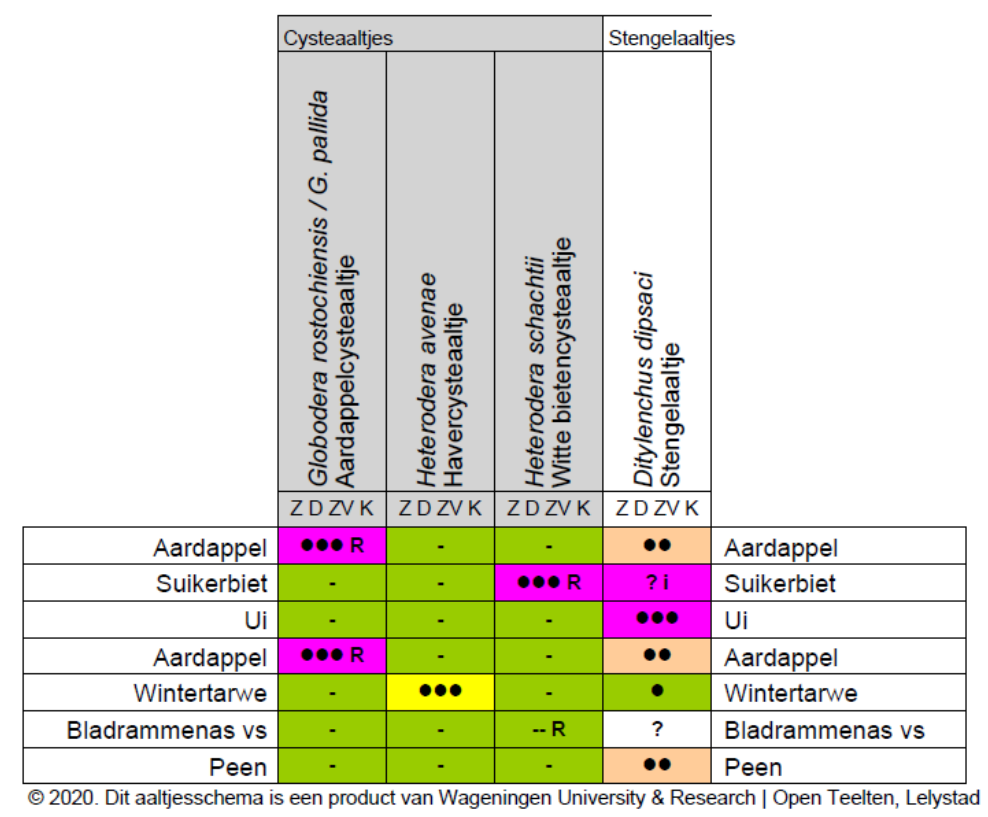

Figuur 7.32 Vermeerdering van en schade door nematoden in het Centraal kleigebied op een akkerbouwbedrijf met aardappelteelt 1:3 (rotatie PA-SB-UI-PA-WT-Groenbemester-PE; uitgangssituatie). 


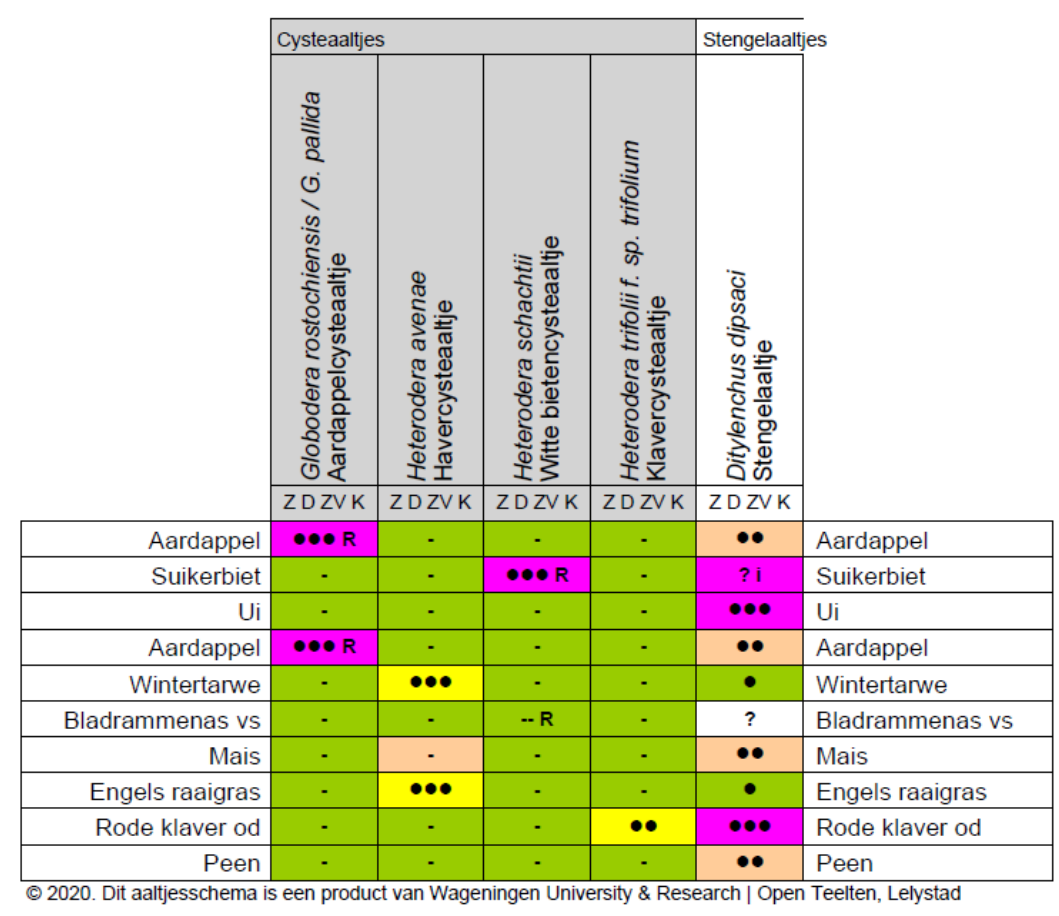

Figuur 7.33 Vermeerdering van en schade door nematoden in het Centraal kleigebied op een akkerbouwbedrijf met aardappelteelt 1:3, waarbij door samenwerken met een melkveehouder een deel van het areaal wintertarwe wordt vervangen door maïs (rotatie PA-SB-UI-PA-WT-

Groenbemester+MA-PE; CEN-2), gras (rotatie PA-SB-UI-PA-WT-Groenbemester+G-PE; CEN-1) of, ter verhoging van de eiwitproductie, grasklaver (rotatie PA-SB-UI-PA-WT-Groenbemester+GK-PE; CEN3).

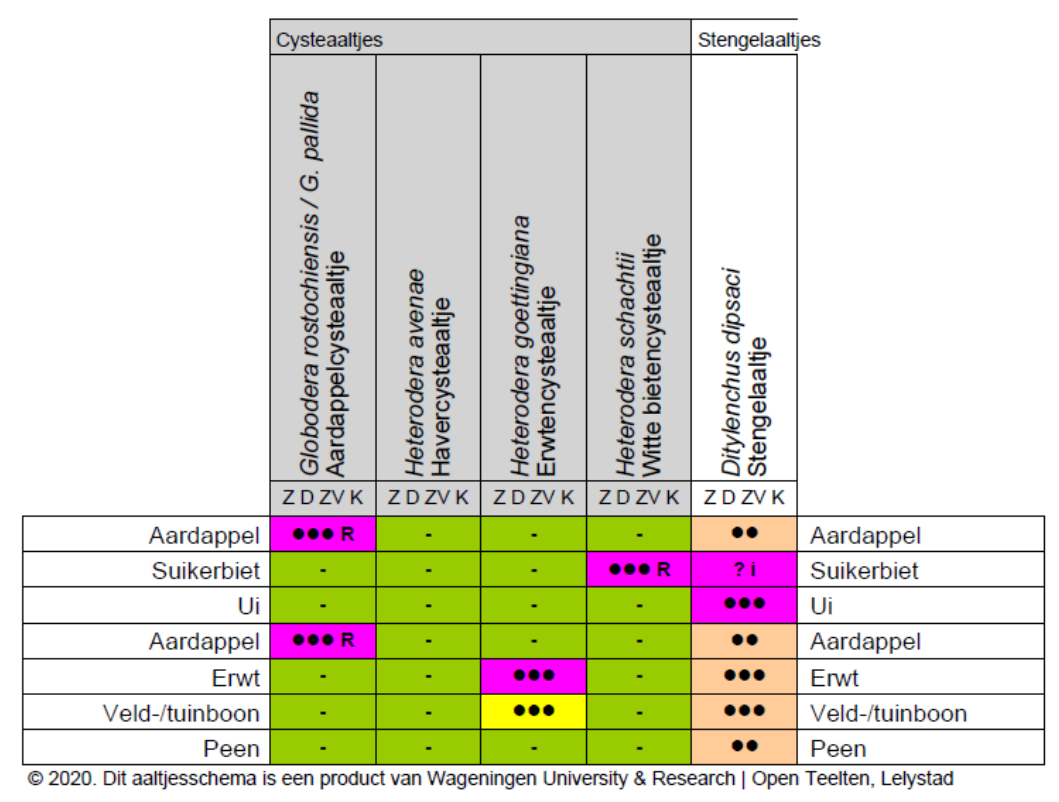

Figuur 7.34 Vermeerdering van en schade door nematoden in het Centraal kleigebied op een akkerbouwbedrijf met aardappelteelt 1:3, waarbij ter verhoging van de eiwitproductie wintertarwe wordt vervangen door erwt (rotatie PA-SB-UI-PA-ER-PE; CEN-4) of veldboon (rotatie PA-SB-UI-PAVBO-PE; CEN-5). 


\subsection{Zuidwest-Nederland (ZWN)}

\subsubsection{Economie}

\subsubsection{Melkveehouderij}

\section{Voederwaarde opbrengst}

De voederwaarde opbrengst voor ZWN-1, waar 11 ha maïs en 44 ha grasland worden verbouwd, is 607 ton droge stof, 567993 kVEM, 82611 kg RE en 36546 DVE (Figuur 7.35).

Door de helft van het areaal maïs te oogsten als MKS neemt de voederwaardeopbrengst af tot respectievelijk 569 ton droge stof, 543503 kVEM, 80520 kg RE en 35772 kg DVE.

Wanneer de helft van het snijmaïs areaal wordt vervangen door luzerne dalen de droge stofopbrengst en de kVEM opbrengst tot respectievelijk 588 ton droge stof en 528959 kVEM. De RE en DVE opbrengst nemen toe tot respectievelijk $88595 \mathrm{~kg}$ RE en 37618 kg DVE.


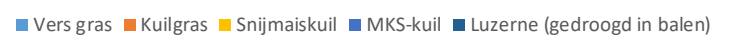

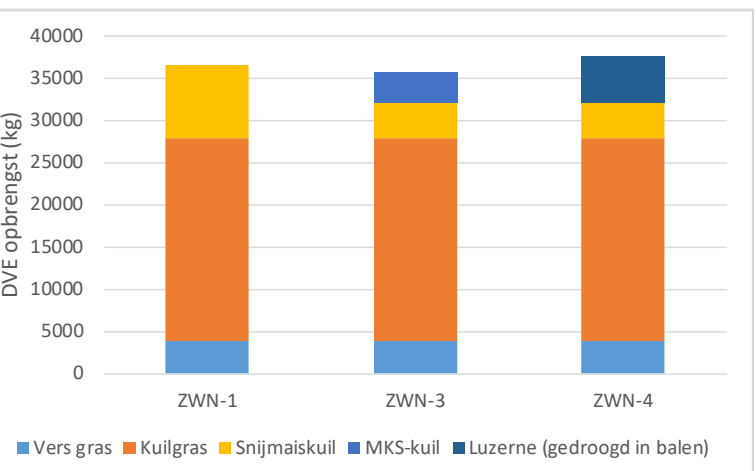

Figuur 7.35 Droge stof, kVEM, ruw eiwit en DVE opbrengst voedergewassen die op naam van het melkveehouderij bedrijf worden verbouwd in de scenario's ZWN-1, ZWN-3 en ZWN-4.

Een maat voor de hoeveelheid melk die een koe kan geven uit de beschikbare droge stof is de VEMDVE verhouding per eenheid VW. Figuur 7.36 laat de VEM-DVE verhouding per eenheid VW voor de geteelde droge stof en de gevoerde droge stof zien.

De VEM-DVE verhouding per eenheid VW van de geteelde droge stof is sterk verschillend voor de drie scenario's. Wanneer de helft van het areaal snijmaïs wordt vervangen door MKS (ZWN-3) of luzerne $(Z W N-4)$ dan neemt de VEM-DVE/VW af van de geteelde droge stof van respectievelijk 16,6 (ZWN-1) naar 16,2 (ZWN-3) en 13,9 (ZWN-4).

Daarmee neemt ook het verschil tussen de VEM/DVE/VW van de geteelde en gevoerde droge stof toe. De VEM/DVE/VW is voor het gevoerde voer $18,5,18,0$ en 17,5 voor respectievelijk ZWN-1, ZWN-3 en ZWN-4 (Figuur 7.36). 


\section{Melkproductie}

Voor de scenario's ZWN-1, ZWN-3 en ZWN-4 was het mogelijk om het niveau van de melkproductie te halen met het aantal dieren (jongvee en melkkoeien) zoals geformuleerd bij de bedrijfsopzet (Bijlage 8-Tabel 6.1). Zoals uit de inkomsten uit melkgeld blijkt (Tabel 7.7) was de melkproductie voor ZWN3 hoger en voor ZWN-4 lager t.o.v. de referentie. Hierbij is gerekend met een melkprijs van $€ 0,36$ per kg melk.

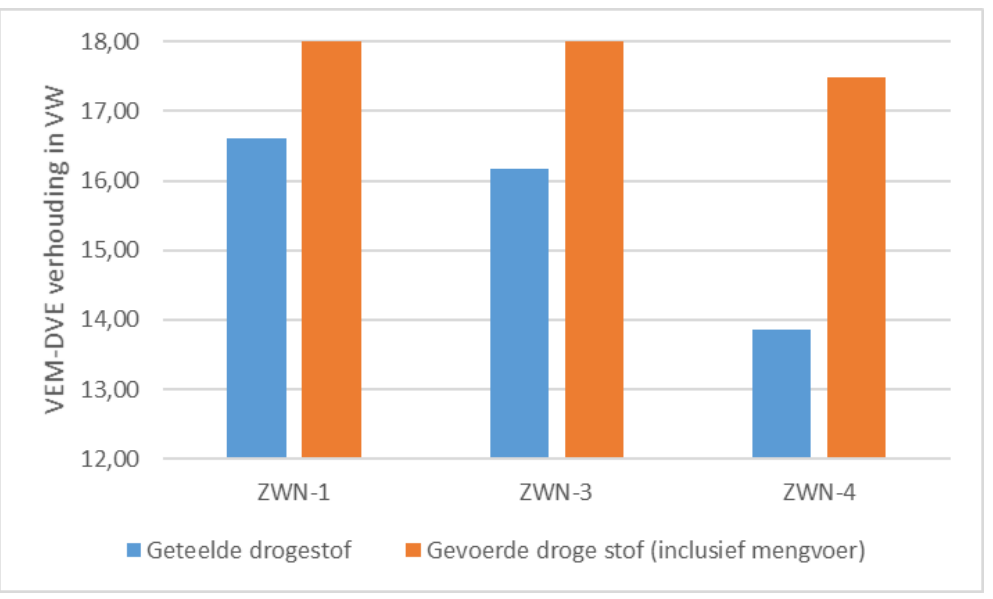

Figuur 7.36 VEM/DVE verhouding per eenheid VW van respectievelijk de geteelde en gevoerde droge stof in de scenario's $Z W N-1, Z W N-3$ en $Z W N-4$.

Tabel 7.7 Opbrengsten en kosten voor het referentie bedrijf en de veranderingen ten opzichte van de referentie voor de andere scenario's in $€ /$ bedrijf.

\begin{tabular}{|c|c|c|c|}
\hline Post / Regio & Kosten & $\Delta$ kosten t.o.v. ZWN-1 & \\
\hline & ZWN-1 & ZWN-3 & ZWN-4 \\
\hline Inkomsten uit melkgeld & 340817 & 1893 & -3240 \\
\hline Opbrengst totaal & 352850 & 1621 & 18182 \\
\hline Herinzaai tijdelijk en blijvend grasland & 3507 & 0 & 0 \\
\hline Teelt gras & 36927 & 0 & 0 \\
\hline Teelt maïs ${ }^{1}$ & 13233 & -6617 & -6617 \\
\hline Teelt MKS & 0 & 6419 & 0 \\
\hline Toediening meststoffen ${ }^{2}$ & 13805 & 0 & 517 \\
\hline Opslag en bewaring ruwvoer ${ }^{3}$ & 10946 & -579 & -1448 \\
\hline Kosten totaal & 156865 & -56 & -1929 \\
\hline Opbrengst minus kosten & 195985 & 1677 & 20111 \\
\hline $\begin{array}{l}\text { Opbrengst minus kosten exclusief inkomsten } \\
\text { uit voerverkoop }\end{array}$ & 183952 & 1949 & -1311 \\
\hline
\end{tabular}

\section{Aan- en verkoop voer}

Tabel 7.7 laat zien dat er voor ZWN-1 $€ 12.033$,- voer verkocht is. Dit betreft het overschot aan kuilgras dat op deze wijze in de studie op waarde is gezet. Anderzijds wordt er $€ 68.031$,- aan voedermiddelen aangekocht. Dit betreft de aankoop van mengvoer. 
Wanneer de helft van het snijmaïs areaal wordt geoogst als MKS (ZWN-3), is het overschot aan kuilgras iets lager en ook de inkomsten uit de verkoop van het kuilgras ( $€ 272,-)$. Wanneer de helft van de snijmaïs wordt vervangen door luzerne (ZWN-4) nemen de inkomsten uit de voerverkoop toe, omdat luzerne tegen een hogere prijs verkocht kan worden dan graskuil.

Voor zowel ZWN-3 als ZWN-4 is de aankoop van voedermiddelen hoger, omdat er meer mengvoer aangekocht moet worden.

Bijlage 7 geeft een overzicht van de hoeveelheden droge stof die met de diverse producten zijn aangekocht en verkocht.

\section{Teelt, bemesting en voeropslag}

De kosten voor de teelt van snijmaïs en MKS zijn vergelijkbaar (Tabel 7.7). De kosten voor opslag en bewaring zijn iets lager, omdat er bij MKS minder product opgeslagen hoeft te worden. Dit resulteert erin dat de kosten voor ZWN-3 vergelijkbaar zijn met die van de referentie (ZWN-1).

Voor het scenario waar de helft van het snijmaïs areaal is vervangen door luzerne (ZWN-4) zijn de kosten $€ 1929$,- lager t.o.v. de referentie (ZWN-1). Dit wordt met name veroorzaakt door de lagere teeltkosten en het feit dat er minder voer opgeslagen hoeft te worden; minder opslag voor maïskuil en de luzerne wordt verkocht.

\section{Opbrengst minus kosten}

Uiteindelijk zijn de opbrengsten minus de kosten voor zowel het scenario waarin de helft van de maïs wordt geoogst als MKS (ZWN-3), als het scenario waarin de helft van het maïsareaal wordt vervangen door luzerne ( $Z W N-4)$ hoger t.o.v. de referentie (Tabel 7.7). Met name door de verkoop van de luzerne is het verschil met $Z W N-1$ en $Z W N-3$ rond de $€ 20.000,-$.

De verkoop van het overschot aan voedermiddelen is sterk bepalend voor de post "Opbrengst minus kosten" zoals de post "Opbrengst minus kosten exclusief inkomsten uit voerverkoop" laat zien.

\subsubsection{Akkerbouw}

In Figuur 7.37 zijn de resultaten weergegeven van de economische bouwplanberekening voor het referentiebouwplan en de bouwplanvarianten op het akkerbouwbedrijf in Zuidwest-Nederland. Doordat de alternatieve bouwplannen ZWN-2 en ZWN-3 dezelfde gewassen en aandelen bevat als het referentiebouwplan ZWN-1 zijn er geen verschillen in het gemiddelde saldo. Voor ZWN-4 is het verschil ten opzichte van de andere scenario's klein. Het saldo ligt voor ZWN-4 iets lager door een verschuiving in het aandeel van graszaad naar wintertarwe. Doordat Bladrammenas als groenbemester op de wintertarwe volgt en het aandeel van dit gewas in het bouwplan toeneemt, stijgen de kosten hiervan ook; bij graszaadteelt fungeert de hergroei na de zaadoogst als groenbemester en hoeft er niet apart een groenbemester worden gezaaid. De kosten van bemesting stijgen in ZWN-4 licht door iets hogere kosten van kunstmest (KM-N).

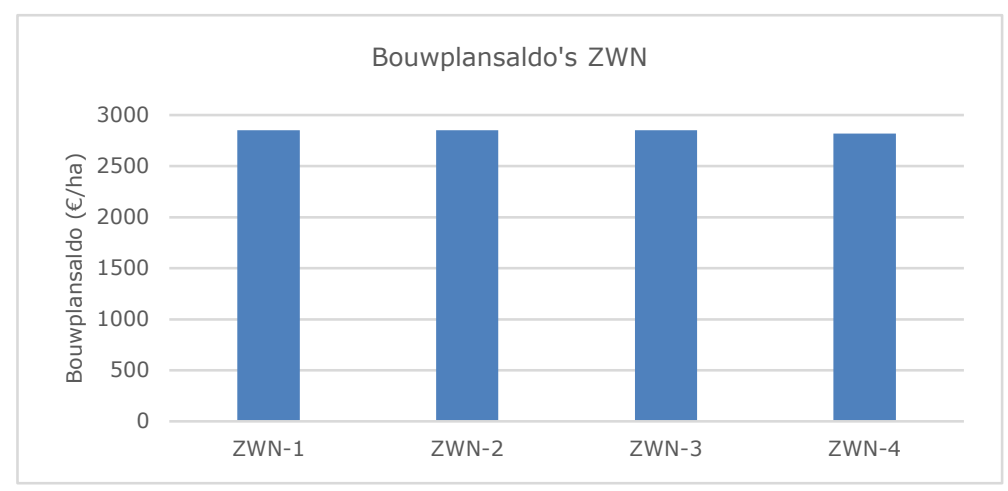

Figuur 7.37 Overzicht gemiddelde bouwplansaldo's Zuidwest-Nederland. 


\subsubsection{Nutriënten en organische stof}

De vervanging van snijmaïs door MKS (ZWN-3) of luzerne (ZWN-4) op het melkveebedrijf leidt niet tot wezenlijke veranderingen in het $\mathrm{N}$ - en $\mathrm{P}_{2} \mathrm{O}_{5}$-bodemoverschot (Figuur 7.38).

Op het akkerbouwbedrijf is bij scenario ZWN-4 ervoor gekozen de ruimte voor het voedergewasareaal te creëren door i.p.v. wintertarwe (zoals in ZWN-1 en ZWN-3) nu het graszaad deels te vervangen door het voedergewas van de melkveehouder (in dit geval luzerne). Dat leidt tot een wat lager $\mathrm{N}$ - en $\mathrm{P}_{2} \mathrm{O}_{5}$-bodemoverschot door de hogere $\mathrm{N}$ - en $\mathrm{P}_{2} \mathrm{O}_{5}$-afvoer van wintertarwe t.o.v. graszaad.

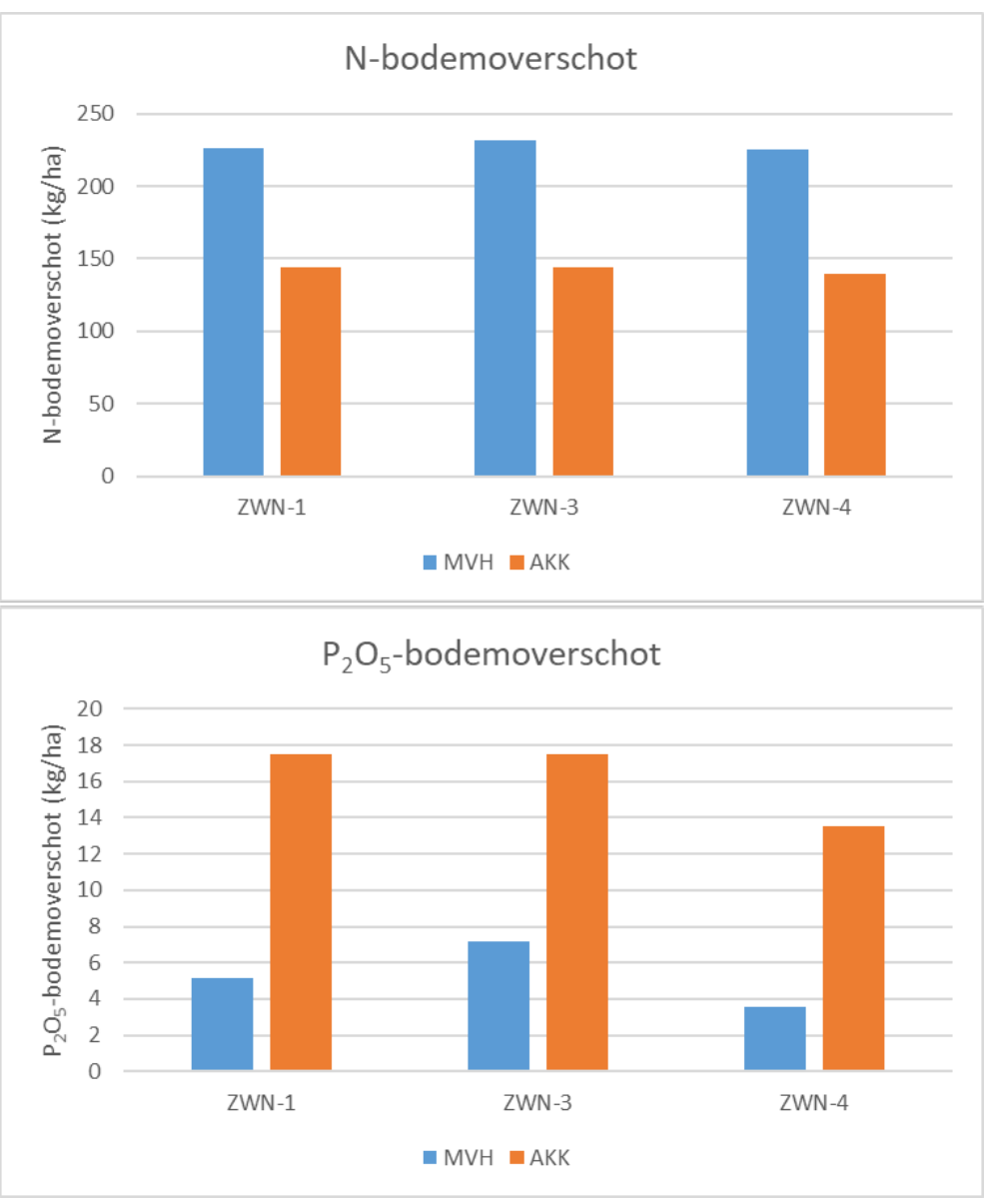

Figuur 7.38 Het $\mathrm{N}$ - en $\mathrm{P}_{2} \mathrm{O}_{5}$-bodemoverschot $(\mathrm{kg} / \mathrm{ha})$ van het melkvee- en akkerbouwbedrijf bij de verschillende bouwplanscenario's in Zuidwest-Nederland.

Op het melkveebedrijf vindt geen verandering plaats in EOS-aanvoer. Op het akkerbouwbedrijf stijgt de EOS-aanvoer indien de maïs wordt vervangen door MKS (ZWN-3) of luzerne (ZWN-4) (Figuur 7.39). Bij beide gewassen is de EOS-aanvoer aanzienlijk hoger dan die van snijmaïs. 




Figuur 7.39 De aanvoer van effectieve organische stof (EOS, $\mathrm{kg}$ per ha) op de grond van het melkveebedrijf ( $B G=$ blijvend grasland, $W B=$ wisselbouw) en het akkerbouwbedrijf bij de verschillende bouwplanscenario's in Zuidwest-Nederland.

\subsubsection{Broeikasgasemissies}

In Tabel 7.8 is voor de verschillende bouwplanvarianten het verschil in BKG-emissies met het referentiebouwplan weergegeven.

Vervanging van een deel van de snijmaïs door MKS (ZWN-3) en luzerne (ZWN-4) leidt tot een daling van de BKG-emissies. Dit is vooral een gevolg van lagere methaan-emissies.

Bij ZWN-4 stijgen de BKG-emissies op het akkerbouwbedrijf. Dat komt, omdat de luzerne die de melkveehouder teelt op het akkerbouwbedrijf, het graszaad vervangt. Hierdoor is er in vergelijking met het referentiebouwplan een hoger aandeel wintertarwe. De BKG-emissies bij dit gewas zijn hoger dan bij graszaad.

Tabel 7.8 Effect van de bouwplanaanpassingen in ZWN op de hoeveelheid broeikasgasemissies ( $k g$ $\mathrm{CO}_{2}$-eq/ha) voor zowel het melkveebedrijf (MVH) als het akkerbouwbedrijf (AKK), uitgedrukt als verschil t.o.v. het referentiebouwplan.

\begin{tabular}{|c|c|c|}
\hline & ZWN-3 & ZWN-4 \\
\hline \multicolumn{3}{|l|}{ MVH } \\
\hline $\mathrm{CO}_{2}$ & -16 & -136 \\
\hline $\mathrm{CH}_{4}$ & -581 & -799 \\
\hline \multicolumn{3}{|l|}{ AKK } \\
\hline $\mathrm{CO}_{2}$ & 0 & 66 \\
\hline $\mathrm{N}_{2} \mathrm{O}$ & 0 & 49 \\
\hline Totaal & 0 & 116 \\
\hline
\end{tabular}

\subsubsection{Bodemgezondheid}

In dit gebied is gekozen om de aandacht alleen te richten op de kleigebieden, al komen ook in het Zuidwestelijk kleigebied lichtere gronden voor. Op zwaardere gronden met een afslibbaarheid van 
$30 \%$ of hoger is er een beperkt aantal aaltjessoorten dat problemen kan veroorzaken. Dit zijn voornamelijk cysteaaltjes (Globodera en Heterodera) en stengelaaltjes (Ditylenchus dipsaci). Op lichtere gronden zal daarnaast ook rekening gehouden moeten worden met mogelijk voorkomen van wortelknobbelaaltjes (Meloidogyne), wortellesieaaltjes (Pratylenchus), vrijlevende aaltjes (Tylenchorhynchus en de trichodoriden Trichodorus primitivus en Paratrichodorus teres) en tabaksratelvirus. Deze problemen zijn vergelijkbaar met die in het Noordoostelijk zand- en dalgebied (7.1.4) en in het Zuidoostelijk zandgebied (7.2.4) en zijn daar beschreven, al komen daar andere trichodoridesoorten voor met iets andere waardplanten.

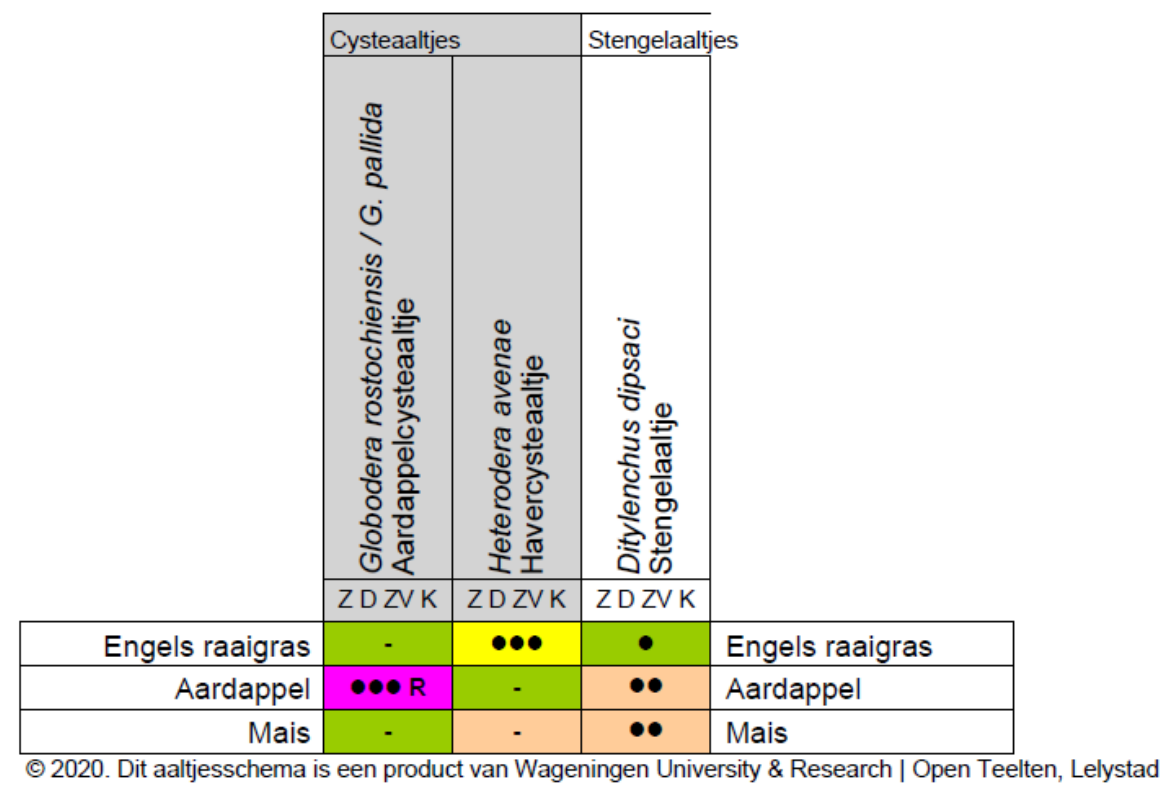

Figuur 7.40 Vermeerdering van en schade door nematoden in het Zuidwestelijk kleigebied op een melkveebedrijf. Rotaties G-G-G-G-G-MA-MA (uitgangssituatie) of G-G-G-G-G-CA-MA (ZWK-1 t/m $Z W K-3)$.

Op een melkveebedrijf op klei met een rotatie met alleen gras en maïs zijn er weinig problemen met nematoden te verwachten. Alleen $H$. avenae zal zich kunnen vermeerderen op gras en matige schade geven in de maïsteelt (Figuur 7.40). Wanneer door samenwerken met een akkerbouwbedrijf ook consumptieaardappel in de rotatie wordt opgenomen, moet ook rekening worden gehouden met de aanwezigheid van aardappelcysteaaltjes (ZWK-1 t/m 3; Figuur 7.40). Deze soort zal in een teelt van $1: 7$ geen problemen geven bij resistente aardappelrassen. Bij de teelt van vatbare aardappelrassen zal de nematode zich mogelijk toch kunnen vermeerderen en over het veld verspreiden. Met een goede grondbemonstering en gebruik van Nemadecide is te bepalen welk aardappelras geteeld kan worden zonder aardappelcysteaaltjes te vermeerderen. Mogelijk kunnen dan ook stengelaaltjes een probleem vormen. Van stengelaaltjes uit aardappel is bekend dat ze zich ook op maïs kunnen vermeerderen en schade veroorzaken.

Op het akkerbouwbedrijf is de teelt van aardappel met 1:4 intensiever dan op het melkveebedrijf

(Figuur 7.41). Hiermee is de keuze van een resistent ras noodzakelijk om schade te voorkomen. Ook hier zijn een goede grondbemonstering en gebruik van Nemadecide voor het bepalen van de raskeuze aan te raden. Met suikerbiet in de rotatie zal ook rekening gehouden moeten worden met aanwezigheid van $H$. schachtii (Figuur 7.41). Bij de teelt van suikerbiet in een rotatie van $1: 5$ zijn doorgaans geen problemen met deze nematode te verwachten, tenzij ook andere gewassen worden verbouwd die de nematode kunnen vermeerderen. Bij het opnemen van bladrammenas als groenbemester na wintertarwe is de keuze voor een resistent ras aan te raden om vermeerdering van $H$. schachtii te voorkomen. Op klei is er geen verschil in risico op problemen met nematoden in de teelt van graszaad tussen Engels en Italiaans raaigras (Figuur 7.41). Stengelaaltjes kunnen een probleem vormen in de teelt van ui, aardappel en suikerbiet. De teelt van wintertarwe en gras vermeerdert deze nematode slecht, al kan deze nematode lange perioden zonder waardplant overleven en nadien weer problemen veroorzaken in gevoelige gewassen. Er bestaan verschillende rassen stengelaaltjes, die visueel niet van elkaar te onderscheiden zijn en waarvan in beperkte mate 
de vermeerdering op verschillende waardplanten bekend is (Schomaker, 2008). Stengelaaltjes uit aardappel en ui kunnen zich waarschijnlijk ook vermeerderen op en schade veroorzaken in suikerbiet en maïs. Vervangen van een teelt wintertarwe-bladrammenas door maïs of mks kan daarmee het risico op schade door stengelaaltjes vergroten (ZWK-1 en ZWK-2; Figuur 7.41).



Figuur 7.41 Vermeerdering van en schade door nematoden in het Zuidwestelijk kleigebied op een akkerbouwbedrijf met aardappelteelt 1:4. Rotatie CA-GZ-GZ-UI-CA-WT-Groenbemester-SB-WTGroenbemester-CA-WT-Groenbemester-SB-UI (uitgangssituatie); bij vervangen van een teelt wintertarwe-groenbemester door maïs of mks wordt de rotatie CA-GZ-GZ-UI-CA-WT-GroenbemesterSB-WT-Groenbemester-CA-MA/MKS-SB-UI (ZWK-1 en ZWK-2).

De tweejarige teelt van graszaad kan worden vervangen door een tweejarige teelt luzerne om de productie van eiwit te verhogen (ZWK-3). Op kleigrond betekent dit vooral een extra risico bij aanwezigheid van stengelaaltjes (Figuur 7.42). Deze kunnen zich goed vermeerderen op luzerne en er schade veroorzaken. Het is niet bekend of stengelaaltjes die zich vermeerderen in luzerne ook schade veroorzaken in aardappel, ui en suikerbiet. Stengelaaltjes uit aardappel kunnen zich niet vermeerderen in luzerne, maar er wel schade veroorzaken. De teelt van luzerne kan de bodemschimmel $V$. dahliae vermeerderen (Figuur 4.1). Dit is geen probleem voor de teelt van ui die daar direct op volgt, maar kan wel een risico vormen voor de teelt van aardappel. Het is onbekend of S. sclerotiorum, dat een risico is voor aardappel, kan vermeerderen op luzerne (Figuur 4.1). 


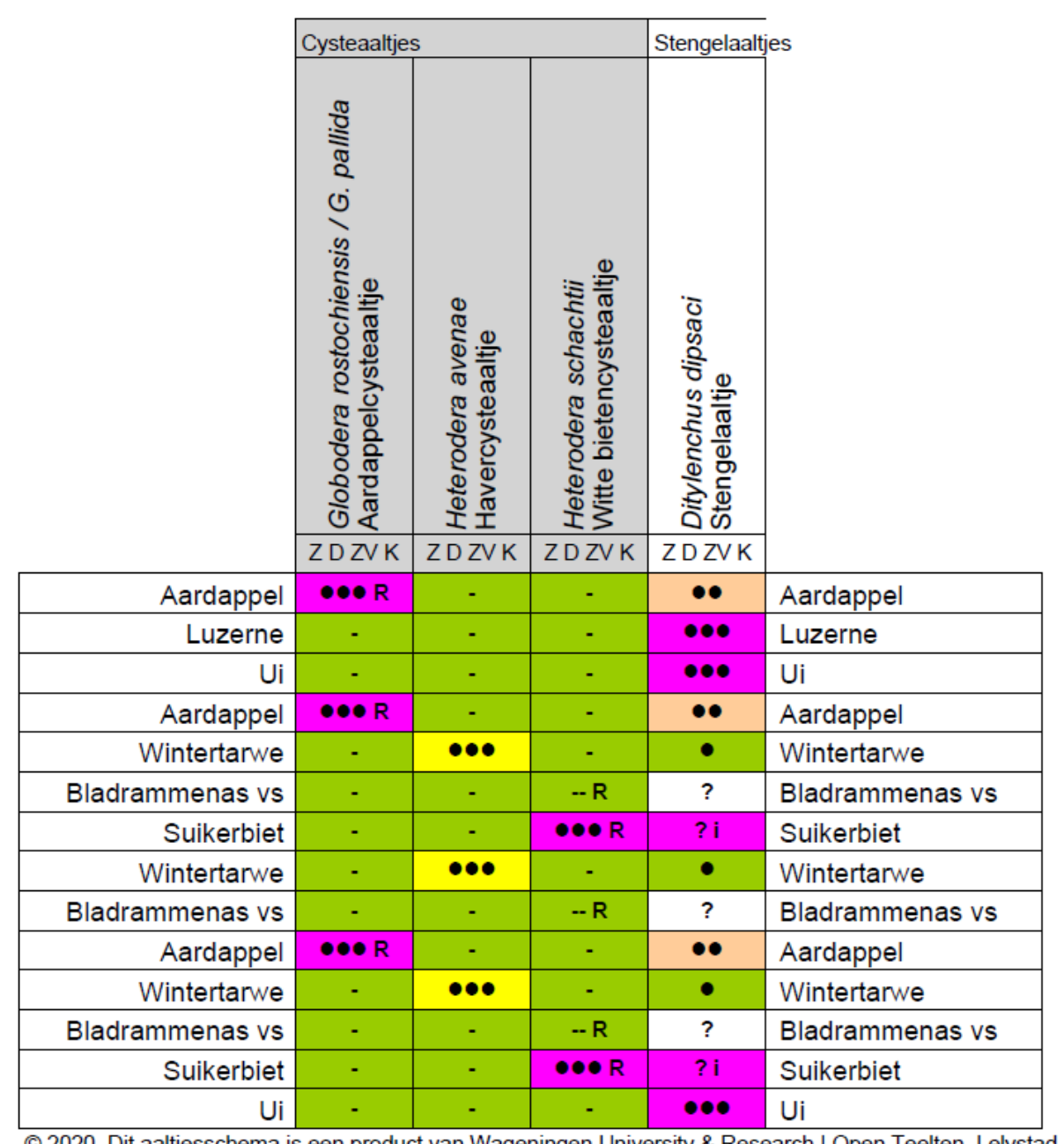

Figuur 7.42 Vermeerdering van en schade door nematoden in het Zuidwestelijk kleigebied op een akkerbouwbedrijf met aardappelteelt 1:4 bij vervangen van graszaad door luzerne. Rotatie CA-LU-LUUI-CA-WT-Groenbemester-SB-WT-Groenbemester-CA-WT-Groenbemester-SB-UI (ZWK-3). 


\subsection{Verkenning organische stof bij gezamenlijk grondgebruik}

In de voorgaande paragrafen zijn voor de verschillende regio's diverse bouwplanvarianten onderzocht m.b.t. gezamenlijk grondgebruik en teelt van eiwitgewassen, waarbij is gekeken naar o.a. economie en emissies. Bij gezamenlijk grondgebruik is er in veel gevallen sprake van een hoger aandeel wisselbouw (d.w.z. afwisseling van gras met bouwlandgewassen) op het melkveebedrijf, terwijl afhankelijk van de gekozen vorm, ook op akkerbouwbedrijven wisselbouwsituaties kunnen gaan voorkomen. Het gevolg is dat het aandeel blijvend grasland afneemt. Een relevante vraag hierbij is welk effect dit heeft op de aanvoer van organische stof en op de koolstofopslag in de bodem. Om hiervan een beeld te krijgen is aanvullend op de eerder genoemde berekeningen een schematische verkenning uitgevoerd via een stapsgewijze aanpassing van grondgebruik op een melkvee- en akkerbouwbedrijf, waarbij varianten worden bekeken uiteenlopend van $100 \%$ blijvend grasland tot $100 \%$ tijdelijk grasland.

Dit hoofdstuk is tot stand gekomen met bijdrage van Sjaak Conijn.

\section{Varianten}

Als voorbeeld is een samenwerking tussen een melkvee- en akkerbouwbedrijf uitgewerkt in Noordoost-Nederland. In de basissituatie heeft het melkveebedrijf $80 \%$ blijvend gras en $20 \%$ continu snijmaïs. Het akkerbouwbedrijf betreft een zetmeelaardappelbedrijf met een rotatie van 1:2 aardappelen, aangevuld met suikerbieten en zomergerst.

Bij de beschrijving van de varianten wordt onder blijvend grasland verstaan dat er altijd gras op het perceel staat. Er vindt wel vernieuwing plaats, maar dan wordt opnieuw gras ingezaaid. In één van de varianten komt 6-jarig grasland voor dat in dit onderzoek als tijdelijk gras wordt aangeduid. Beleidsmatig wordt grasland dat minstens 5 jaar achter elkaar gras is geweest, aangemerkt als blijvend grasland. Dit wijkt af van onze definitie waarin grasland als blijvend wordt aangemerkt indien er geen onderbreking is met een bouwlandperiode.

De beschouwde varianten staan in Tabel 7.9:

- De basissituatie wordt beschreven in variant 1, waarin er geen grondruil is tussen het melkvee- en het akkerbouwbedrijf. In deze situatie is op het melkveebedrijf al het gras blijvend grasland en wordt de maïs in continuteelt geteeld. Er is vanuit gegaan dat het grasland eens in de 10 jaar wordt vernieuwd. Op het akkerbouwbedrijf worden de zetmeelaardappelen (1:2) afgewisseld met suikerbieten (1:4) of zomergerst (1:4).

- In variant 2 is er ook geen grondruil, maar wordt de snijmaïs op het melkveebedrijf in wisselbouw geteeld. Er is onderscheid gemaakt in 2 sub-varianten: in de wisselbouw wordt uitgegaan van 2jarig grasland en 2 jaren snijmaïs (variant 2A) en van 4-jarig grasland en 4 jaren snijmaïs (variant $2 B$ ). In beide gevallen is $75 \%$ van het grasland blijvend en $25 \%$ tijdelijk (respectievelijk $60 \%$ en $20 \%$ van het totale bedrijfsareaal). Op het akkerbouwbedrijf verandert niets t.o.v. variant 1.

- In variant 3 is er sprake van grondruil, waarbij aardappels worden geteeld op het melkveebedrijf en een deel van de snijmaïs op het akkerbouwbedrijf wordt geteeld. De aardappels op het melkveebedrijf betreft extra pootaardappelteelt, waarbij het areaal zetmeelaardappelen op het akkerbouwbedrijf gelijk blijft. Om ruimte te creëren voor de snijmaïs wordt er op het akkerbouwbedrijf minder zomergerst geteeld. Dit is een grondruilsituatie die veel voorkomt in de regio. Er zijn 3 sub-varianten onderscheiden met, respectievelijk, 2-, 4- en 6-jarig grasland in het wisselbouwdeel van het melkveebedrijf met in alle drie varianten een bouwlandperiode van 2 jaar (respectievelijk varianten $3 \mathrm{~A}, 3 \mathrm{~B}$ en $3 \mathrm{C}$ ). Het aandeel blijvend grasland neemt in deze varianten af van $75 \%$ naar $25 \%$.

- In variant 4 is er sprake van een volledig geïntegreerde rotatie op beide bedrijven. Er is alleen maar tijdelijk grasland (2-jarig).

Bij de organische mestaanvoer is op het melkveebedrijf uitgegaan van een aanvoer van $230 \mathrm{~kg} \mathrm{~N}$ per ha met rundveedrijfmest. Op het akkerbouwbedrijf wordt $50 \mathrm{~kg} \mathrm{~N}$ per ha met rundveedrijfmest en 72 $\mathrm{kg} \mathrm{N}$ per ha met varkensdrijfmest gebruikt. De totale hoeveelheid dierlijke mest op het akkerbouw- en melkveebedrijf tezamen was voor alle scenario's gelijk. Via kengetallen uit het "Handboek Bodem en Bemesting" zijn de bijbehorende drijfmestgiften (in $\mathrm{m}^{3}$ per teelt) opgezocht. Na de oogst van snijmaïs (zonder herinzaai van gras) en zomergerst is er een groenbemester ingezaaid dat in het daaropvolgend voorjaar wordt ondergeploegd. Dit levert een extra bron voor organische stof op (kengetallen genomen uit het Handboek). 
Tabel 7.9 Overzicht van de bouwplanvarianten.

\begin{tabular}{|c|c|c|c|c|c|c|c|c|c|c|c|c|c|c|}
\hline Variant: & 1 & & $2 \mathrm{~A}$ & & 2B & & $3 A$ & & 3B & & $3 C$ & & 4 & \\
\hline Wel/geen grondruil: & Geen & & Geen & & Geen & & Ja & & $\mathrm{Ja}$ & & Ja & & Ja & \\
\hline \multirow{2}{*}{ Wel/geen wisselbouw op MVH: } & \multirow[t]{2}{*}{ Nee } & & $\mathrm{Ja}$ & & $\mathrm{Ja}$ & & $\mathrm{Ja}$ & & Ja & & Ja & & Ja & \\
\hline & & & \multicolumn{2}{|c|}{2 jaar gras, 2 jaar mais } & \multicolumn{2}{|c|}{4 jaar gras, 4 jaar mais } & \multicolumn{2}{|c|}{2 jaar gras, 2 jaar bouwland } & \multicolumn{2}{|c|}{4 jaar gras, 2 jaar bouwland } & \multicolumn{2}{|c|}{6 jaar gras, 2 jaar bouwland } & \multicolumn{2}{|c|}{ Volledig geïntegreerde rotatie } \\
\hline Gewasareaal (ha) & MVH & AKK & MVH & AKK & MVH & AKK & MVH & AKK & MVH & AKK & MVH & AKK & MVH & AKK \\
\hline Blijvend gras & 48 & & 36 & & 36 & & 36 & & 24 & & 12 & & & \\
\hline Tijdelijk gras, 2-jarig & & & 12 & & & & 12 & & & & & & 24 & 24 \\
\hline Tijdelijk gras, 4-jarig & & & & & 12 & & & & 24 & & & & & \\
\hline Tijdelijk gras, 6-jarig & & & & & & & & & & & 36 & & & \\
\hline Snijmais & 12 & & 12 & & 12 & & 6 & 6 & 6 & 6 & 6 & 6 & 6 & 6 \\
\hline Pootaardappel & & & & & & & 6 & & 6 & & 6 & & 6 & \\
\hline Zetmeelaardappel & & 30 & & 30 & & 30 & & 30 & & 30 & & 30 & 12 & 18 \\
\hline Suikerbiet & & 15 & & 15 & & 15 & & 15 & & 15 & & 15 & 9 & 6 \\
\hline Zomergerst & & 15 & & 15 & & 15 & & 9 & & 9 & & 9 & 3 & 6 \\
\hline Totaal areaal, ha & 60 & 60 & 60 & 60 & 60 & 60 & 60 & 60 & 60 & 60 & 60 & 60 & 60 & 60 \\
\hline & & & & & & & & & & & & & & \\
\hline Blijvend gras, fr van totaal gras & 1.00 & & 0.75 & & 0.75 & & 0.75 & & 0.50 & & 0.25 & & 0.00 & \\
\hline
\end{tabular}




\section{Resultaten organische stofaanvoer}

$\mathrm{Er}$ is onderzocht of de varianten een effect hebben op de organische stofaanvoer naar de bodem. Dit is gedaan voor het melkvee- en het akkerbouwbedrijf afzonderlijk en voor het totaal van beide typen bedrijven. We hebben gebruik gemaakt van kengetallen over de hoeveelheid organisch stofaanvoer en bijbehorende humificatie-coëfficiënten (hc). Deze coëfficiënten geven aan welk deel van de oorspronkelijke organische stofaanvoer na 1 jaar in de bodem nog over is. Dit deel wordt dan beschouwd als bodemorganische stofaanvoer en wordt effectieve organische stof (EOS) genoemd. De gebruikte kengetallen zijn afkomstig van het "Handboek Bodem en Bemesting" (https://www.handboekbodemenbemesting.nl/). Ze zijn specifiek voor ieder type organische stofaanvoer en worden mede bepaald door het management (bijv. bij drijfmestgift). Voor grasland zijn de kengetallen van het Handboek aangepast op basis van een recente analyse van beschikbare informatie (ongepubl. resultaten, Sjaak Conijn). We hebben de volgende aanvoerposten voor organische stof onderscheiden:

(1) gewasresten die op het veld achterblijven (boven- en ondergronds),

(2) groenbemester dat in het voorjaar ondergeploegd wordt,

(3) organische mesttoedieningen (rundvee- en varkensdrijfmest) en

(4) de graszode die wordt ondergeploegd bij herinzaai en in de wisselbouwsituaties.

Bij gras bestaan de gewasresten uit afgestorven delen (natuurlijke afsterving) en oogstverliezen op het veld. Per perceel zijn de verschillende posten (voor zover van toepassing) bepaald en voor de hele rotatie uitgerekend. Vervolgens zijn ze voor het hele bedrijf samengevat door rekening te houden met de arealen van de verschillende teelten op het bedrijf. In Tabel 7.10 worden de resultaten van de aanvoer van EOS op bedrijfsniveau getoond.

Tabel 7.10 Effectieve organische stofaanvoer naar de bodem (in $\mathrm{kg}$ per ha per jaar)

\begin{tabular}{|c|c|c|c|c|c|c|c|}
\hline Variant & 1 & $2 \mathrm{~A}$ & $2 B$ & 3A & 3B & $3 C$ & 4 \\
\hline \multicolumn{8}{|l|}{ MKV } \\
\hline (1) gwsrest & 3043 & 2974 & 3017 & 3003 & 3020 & 3038 & 1898 \\
\hline (3) orgmest & 2863 & 2863 & 2863 & 2654 & 2654 & 2654 & 1778 \\
\hline (4) grszode & 44 & 235 & 134 & 235 & 224 & 213 & 404 \\
\hline \multicolumn{8}{|l|}{ AKK } \\
\hline (1) gswrest & 1048 & 1048 & 1048 & 985 & 985 & 985 & 1884 \\
\hline (2) grbemest & 208 & 208 & 208 & 183 & 183 & 183 & 83 \\
\hline (3) orgmest & 888 & 888 & 888 & 1087 & 1087 & 1087 & 1968 \\
\hline \multicolumn{8}{|l|}{ MKV+AKK } \\
\hline (1) gswrest & 2045 & 2011 & 2032 & 1994 & 2003 & 2011 & 1891 \\
\hline (2) grbemest & 162 & 133 & 148 & 121 & 121 & 121 & 62 \\
\hline (3) orgmest & 1876 & 1876 & 1876 & 1871 & 1871 & 1871 & 1873 \\
\hline (4) grszode & 22 & 117 & 67 & 117 & 112 & 106 & 404 \\
\hline Totaal & 4105 & 4137 & 4123 & 4103 & 4106 & 4109 & 4231 \\
\hline
\end{tabular}

Bij het melkveebedrijf zijn de verschillen in totale EOS aanvoer tussen de varianten $1 \mathrm{t} / \mathrm{m} 3 \mathrm{C}$ zeer klein en kun je concluderen dat de verschillen in blijvend en tijdelijk gras (van $100 \%$ naar $25 \%$ blijvend grasland van het totale graslandareaal op het bedrijf) niet hebben geleid tot verschillen in EOS aanvoer volgens onze analyse. Bij deze varianten valt op dat in de onderliggende posten met name verschillen optreden in groenbemester (bijdrage het hoogst in variant 1 bij continue maïsteelt), organische mest (vanaf variant 3A meer mest naar het akkerbouwbedrijf) en graszode (bijdrage het laagst in variant 1 bij 100\% blijvend grasland dat "slechts" om de 10 jaar wordt vernieuwd). Het verschil van de varianten $1 \mathrm{t} / \mathrm{m} 3 \mathrm{C}$ t.o.v. variant 4 is wel groot: bijna $1900 \mathrm{~kg}$ EOS per ha per jaar minder aanvoer op het melkveebedrijf bij volledige integratie van beide bedrijven. Dit verschil wordt vooral veroorzaakt door minder grasland en minder organische mesttoediening. 
$\mathrm{Bij}$ het akkerbouwbedrijf zijn in de tabel voor iedere variant getallen getoond, maar de varianten $1,2 \mathrm{~A}$ $\mathrm{t} / \mathrm{m} 2 \mathrm{~B}$ verschillen onderling niet en dit geldt ook voor $3 \mathrm{~A} t / \mathrm{m} 3 \mathrm{C}$, waardoor er voor dit bedrijf in totaal 3 verschillende varianten overblijven. Wederom zijn de verschillen in de totale EOS aanvoer tussen de varianten $1,2 A B$ en $3 A B C$ op het akkerbouwbedrijf zeer klein. Van de onderliggende posten valt vooral op dat er in variant $3 A B C$ meer mest wordt toegediend, wat afkomstig is van het melkveebedrijf. In variant 4 is er een duidelijke verhoging zichtbaar van circa $2100 \mathrm{~kg}$ EOS per ha per jaar als gevolg van met name meer grasland en meer organische mest.

Uit bovenstaande blijkt dat voor het gemiddelde van de twee bedrijven de EOS aanvoer praktisch gelijk blijft bij de eerst 6 varianten (1 t/m 3C). In variant 4 is er een toename van bijna $120 \mathrm{~kg}$ EOS per ha per jaar dat wordt veroorzaakt door de EOS toename van de graszode (door meer tijdelijk gras) ondanks lagere EOS aanvoer via gewasresten en de groenbemester. De totale toename bedraagt slechts $3 \%$ van de gemiddelde EOS aanvoer in de varianten $1 \mathrm{t} / \mathrm{m} \mathrm{3C}$. Opvallend is het grote verschil in EOS aanvoer (ruim $3800 \mathrm{~kg}$ EOS per ha per jaar) tussen het melkveebedrijf en het akkerbouwbedrijf bij de varianten $1 \mathrm{t} / \mathrm{m} 3 \mathrm{C}$. Dit verschil wordt voor $52 \%$ verklaard door het verschil in gewasrest (gras versus akkerbouwgewas) en voor $46 \%$ door organische mesttoediening (hoger op het melkveebedrijf).

\section{Koolstofopslag in bodem}

De EOS aanvoer zorgt voor aanvulling van de voorraad organische stof in de bodem. Indien de afname van de bestaande voorraad gedurende een jaar gelijk is aan de jaarlijkse EOS aanvoer (zie bijv. tabel 2), blijft de voorraad gelijk. Een hoger organische stofniveau wordt bereikt als de aanvoer groter is dan de afname. Om vast te stellen welk kant het opgaat, is het nodig om een aantal aspecten te beschouwen:

\section{Bodemlaag}

Het is van belang om een relevante bodemlaag te selecteren waarvan je de voorraad organische stof bepaalt. Voor de teelt zal de bouwvoor (tot ca. $25 \mathrm{~cm}$ diepte) van belang zijn vanwege de gunstige eigenschappen van organische stof in die laag voor gewasgroei. Echter, voor de (totale) koolstofopslag in de bodem, zouden ook diepere lagen in de bodem meegenomen moeten worden. Op minerale gronden neemt over het algemeen de organische stof in de bodem met de diepte af. De meeste organische stof bevindt zich dan bovenin, maar ook onder een diepte van bijv. $60 \mathrm{~cm}$ bevindt zich nog steeds organische (kool)stof. In veel analyses over de dynamiek van de organische stof in de bodem van akkerbouwteelten wordt een bodemlaag gekozen tot maximaal $25-30 \mathrm{~cm}$ onder maaiveld. Dan wordt de bouwvoor meegenomen. Bij routine metingen in graslanden werd lange tijd alleen de laag 0$5 \mathrm{~cm}$ bemonsterd, maar sinds een aantal jaren is dat veranderd in $0-10 \mathrm{~cm}$. Voor beide keuzes (akkerbouw: maximaal $30 \mathrm{~cm}$ en grasland: $10 \mathrm{~cm}$ ) geldt dat er veel bodemorganische (kool)stof buiten beschouwing blijft, respectievelijk onder de $30 \mathrm{~cm}$ en $10 \mathrm{~cm}$, en dit beperkt ons inzicht in welke kant het opgaat met de totale koolstofopslag in de bodem bij een bepaalde EOS aanvoer.

\section{Afname organische stof}

Als er geen aanvoer is van organische stof naar de bodem dan neemt de voorraad in een bodemlaag normaliter af. Hiervoor zijn twee processen verantwoordelijk: afbraak van de bestaande organische stof (omzetting naar o.a. $\mathrm{CO}_{2}$ ) en uitspoeling/afspoeling naar respectievelijk diepere bodemlagen en het oppervlakte water. Onderscheid tussen deze processen wordt niet altijd gemaakt of gemeten en berekende afnames in de bovenste bodemlaag worden dan vaak volledig toegeschreven aan afbraak. Afbraakpercentages zijn van een aantal factoren afhankelijk, zoals grondsoort, ontwatering, temperatuur en mate van afbreekbaarheid van de organische stof. Ook kan een deel van de aanwezige organische stof (zeer) resistent tegen afbraak zijn, bijv. omdat dit deel afkomstig is van vroeger, waarbij het grondgebruik anders was dan het huidige grondgebruik. Mogelijk is er ook een relatie met de diepte waarbij de organische stof in diepere lagen minder snel afbreekt door de daar heersende omstandigheden of omdat het ouder en resistenter materiaal betreft. Door deze factoren is er veel variatie in afbraakpercentages waardoor de onzekerheid over de afbraak in een bepaalde situatie groot is.

\section{Relatie met verschillen in EOS-aanvoer}

Op basis van de verschillen in EOS aanvoer en met de aanname dat de EOS van de verschillende bouwplanvarianten met dezelfde snelheid verder afbreken in de bodem, zou je verwachten dat er in de permanente graslandpercelen met een EOS aanvoer van $6770 \mathrm{~kg}$ EOS per ha per jaar circa $3 x$ zoveel 
organische stof ophoopt in vergelijking met het akkerbouwbedrijf van variant 1 . Dit grote verschil komt niet overeen met metingen van Eurofins. In een analyse van Eurofins (Brolsma et al., 2017) werden voor het oostelijk veehouderijgebied organische stofgehaltes van circa $4.5 \%$ en $5.5 \%$ bepaald voor respectievelijk akkerbouw- en graslandsituaties (bodemlagen van 0-25 cm en 0-10 cm). Dit komt overeen met de bevindingen in Conijn \& Lesschen (2015; tabel 5). Mogelijke verklaringen voor deze afwijking kunnen zijn dat de bemonsterde percelen in het verleden niet altijd grasland of akkerbouwland waren en dat er aanvullend compost gebruikt is in de akkerbouw. In een 36-jarige proef in Melle (België; 1966 - 2004; Eekeren, van et al., 2008) met permanent grasland (PG), continu teelt maïs (PA) en gras-maïs wisselbouw (3:3) werd een organisch stofgehalte in de bodemlaag 0 - 10 $\mathrm{cm}$ van PG van $6.1 \%$ en van PA van $2.1 \%$ gemeten (gemiddelden van $2002-2004$ ). In Melle zijn ook bulkdichtheden gemeten en daarmee werd de voorraad organische stof bepaald in PG (69 ton per ha) en in PA (30 ton per ha). Op basis van de EOS aanvoeren zoals in deze studie gebruikt (respectievelijk 3720 en $680 \mathrm{~kg}$ EOS per ha per jaar voor gras en maïs) zou de voorraad in permanent grasland minimaal een factor 5 hoger ingeschat kunnen worden na het bereiken van de evenwichtstoestand. Dit wijkt significant af van de factor 2.3 die met de resultaten van Melle berekend werd. Dit zou verklaard kunnen worden door de te korte proefduur waarin het evenwicht (waarschijnlijk) nog niet bereikt is ten aanzien van de organische stofvoorraad in de bodem. Vergelijking van de EOS aanvoer waarden met metingen uit de praktijk van organische stofvoorraden worden dus bemoeilijkt door onduidelijkheden over het management in het verleden en het verschil tussen de gemeten waarden in de praktijk en het evenwicht bij constante aanvoer van EOS.

\section{Ploegen}

Door meer tijdelijk grasland ten koste van blijvend grasland in de varianten $2 \mathrm{~A} \mathrm{t} / \mathrm{m} 4$ t.o.v. variant 1 , zal er ook vaker geploegd worden. Dit kan een effect hebben op de afbraak van de organische stof. Het is moeilijk vast te stellen hoe groot dit effect is. In berekeningen van de IPCC voor de opslag van koolstof in de bodem is er een onderscheid gemaakt tussen niet ploegen ("no till") en jaarlijks ploegen ("conventional tillage"). Er wordt hierin aangenomen dat het evenwichtsniveau van de voorraad koolstof bij jaarlijks ploegen circa $14 \%$ lager is dan bij niet ploegen. Onduidelijk is of dit verschil overal optreedt, bijv. zowel in akkerbouw- als in graslandsituaties en zowel op zand als op klei. In Vellinga et al. (2004) wordt aangenomen dat graslandvernieuwing tot meer afbraak leidt in vergelijking tot permanent grasland, maar onduidelijk is of specifieke proeven die dit aantonen hieraan ten grondslag liggen. Uit de resultaten van de eerder genoemde proef in Melle kan de conclusie getrokken worden dat een wisselbouwsituatie tot $5 \%$ minder koolstof in de bodem leidt t.o.v. permanent gras. Dit resultaat is gebaseerd op het verschil in koolstofvoorraad in de bodem van wisselbouwteelten ( 3 jaar gras en 3 jaar maïs) en het gemiddelde van twee permanente teelten PG en PA (gras en maïs). Verloop et al. (2015) concludeerde op basis van onderzoek naar de organische stofdynamiek op proefbedrijf De Marke dat de frequentie van ploegen geen invloed had op de dynamiek van de bodemorganische stof. In veel gevallen zijn proeven, zoals boven vermeld, niet specifiek opgezet om het effect van vaker ploegen in permanent grasland te meten en hierdoor is de onzekerheid over een eventueel effect groot.

\section{Samenvatting}

Samenvattend kan geconcludeerd worden dat de onzekerheden (te) groot zijn om betrouwbare uitspraken te doen over de voorraad organische (kool)stof in de bodem. Het is onduidelijk of die voorraad met de EOS aanvoer uit tabel 2 stabiel blijft, toeneemt of afneemt in de toekomst. 
106 | Rapport WPR-1062 


\section{Discussie}

Bij de interpretatie van de uitkomsten van deze studie is het belangrijk om de uitkomstens te bezien binnen de uitgangspunten zoals die zijn gesteld bij de berekeningen van de scenario's. Hieronder worden een aantal aandachtspunten genoemd.

\section{Aangekocht voer}

Bij de berekening van de rantsoenen is ervoor gekozen om de behoefte van de veestapel zoveel mogelijk in te vullen met voedermiddelen die op het eigen bedrijf zijn geteeld, aangevuld met mengvoer. Bijproducten zijn niet ingerekend. Dit is de verklaring voor het feit dat in de regio Centraal-Nederland in deze studie niet het melkproductie niveau kan worden gerealiseerd dat wel in de praktijk wordt gerealiseerd.

\section{Opbrengst blijvend en tijdelijk grasland}

De grasopbrengst van blijvend en tijdelijk grasland in deze studie aan elkaar gelijk gesteld. Vanuit de praktijk is de ervaring dat de grasopbrengst van tijdelijk grasland hoger is dan die van blijvend grasland. De vermeldingen in de literatuur zijn hier echter niet eenduidig over. Het optreden van verschil in opbrengst tussen tijdelijk grasland en blijvend grasland wordt wel geweten aan de uitvoering van het graslandmanagement; gecombineerd gebruik van weiden en maaien enerzijds versus alleen maaien anderzijds, en het optreden van schade aan de zode.

\section{Weidegang}

Aangezien er geen cijfers bekend zijn over de hoeveelheid gras die wordt opgenomen tijdens de uren weidegang is in deze studie aangenomen dat, indien weidegang wordt toegepast, twee derde van de grasopbrengst wordt geoogst als graskuil en een derde als weidegras. Dit resulteert in een aandeel weidegras in het rantsoen van 0,6 tot 1,2 kg droge stof per koe per dag gemiddeld over het hele jaar voor het referentiebedrijf van respectievelijk regio Noordoost-Nederland en regio Zuidwest-Nederland (in de andere regio's werd niet beweid). Uitgaande van 180 dagen weidegang op jaarbasis resulteert dit in 1,2 tot $2,4 \mathrm{~kg}$ droge stof per koe per dag uit weidegras in het rantsoen gedurende het weideseizoen. Door deze aanname worden verschillen in bedrijfsopzet tussen de regio's met technische mogelijkheden voor weidegang en de houding met betrekking tot weidegang mogelijk niet onderkend.

\section{Overschot voedermiddelen}

In een aantal scenario's is er een overschot aan voedermiddelen. Het overschot aan voedermiddelen wordt in deze studie zichtbaar gemaakt door het overschot te verkopen. In de praktijk is in jaren met gemiddelde weersomstandigheden de handel in kuilgras zeer beperkt en blijft het kuilgras als voorraad op het bedrijf aanwezig.

In de scenario's waar beweiding wordt toegepast kan het overschot aan graskuil worden verlaagd door minder gras te oogsten als kuilgras en een groter aandeel als weidegras. Door de hogere voederwaarde van weidegras zal dit een verschuiving geven in de hoeveelheid eiwit dat aangekocht dient te worden en de emissies die gaan optreden.

\section{Aandeel grasland}

In deze studie is ervoor gekozen om in de meeste scenario's het aandeel grasland in de bouwplannen op $80 \%$ van het bedrijfsareaal te houden, omdat dit een voorwaarde is in de huidige wetgeving om voor derogatie in aanmerking te komen. De resultaten van de rantsoenberekeningen laten zien dat het aandeel grasland op het bedrijf niet in overeenstemming is met de behoefte aan energie en eiwit (hoeveelheid en verhouding) die nodig is om de veestapel te voeden. Er is een overschot aan graskuil op de referentiebedrijven in Noordoost-Nederland, Centraal-Nederland en Zuidwest-Nederland, terwijl er snijmaïs wordt aangekocht voor het referentiebedrijf in Zuidoost-Nederland. 
Dit pleit ervoor om vanuit optimalisatie van de teelt van eigen voer de verhouding waarin de gewassen die op het bedrijf geteeld worden in relatie tot de bedrijfsopzet (het aantal GVE per ha grasland is ligt rond de 2,8 voor Noordoost-Nederland, Centraal-Nederland en Zuidwest-Nederland en 3,8 voor Zuidoost-Nederland) te herzien op het aandeel grasland in het bedrijfsareaal. Binnen de huidige wetgeving is de plaatsing van mest voor veehouders een voorwaarde voor de keuze van de teelt van een gewas. Maar in het kader van de contouren van het nieuwe mestbeleid is mestplaatsing als keuze voor een gewas minder relevant.

\section{Bouwplan en energie/eiwitbehoefte}

De aanpassingen in de bouwplannen van de referentiebedrijven die zijn doorgerekend in de verschillende scenario's, zijn opgesteld vanuit de teeltkundige aspecten en de mogelijkheden voor grondruil met het akkerbouwbedrijf waren hierbij leidend. De verhouding van energie en eiwit in het bouwplan voor de invulling van de voederbehoefte van de veestapel is in deze keuze buiten beschouwing gelaten. Door deze benadering wordt duidelijk wat de mogelijkheden voor grondruil tussen akkerbouwer en melkveehouder zijn. Echter, de mogelijkheden voor melkveehouder en akkerbouwer om naast samenwerking door grondruil ook samen te werken door gewassen aan elkaar te verkopen zijn niet verder uitgewerkt in deze studie.

\section{Toerekening herinzaaikosten}

Bij gezamenlijk grondgebruik is er in veel gevallen sprake van meer wisselbouw. Dat betekent dat de herinzaaikosten toenemen. Dit is met name het geval voor varianten met vergaande integratie van melkveehouderij- en akkerbouwgewassen (zoals doorgerekend voor Noordoost-Nederland). In de berekeningen zijn deze kosten volledig toegerekend aan het melkveehouderijbedrijf, waardoor deze varianten minder aantrekkelijk zijn voor de melkveehouder. Om de samenwerking voor beide partijen aantrekkelijk te houden, is het van belang de kosten en opbrengsten zo gelijkmatig mogelijk te verdelen.

\section{Verschuiving in teelten bij samenwerking}

Bij de beschrijving van de referentiesituaties is aangegeven dat bij het aangaan van de samenwerking de akkerbouwer doorgaans meer aardappelen gaat telen, vaak door een deel van het graan in te leveren. Hierbij moet worden benadrukt dat extra teelt van een gewas alleen logisch en zinvol is als daar ook een markt voor is.

\section{Klimaatverandering en teelt van voedergewassen}

De berekeningen in de klimaatscenario's geven aan dat de opbrengst van gras en maïs zullen afnemen als gevolg van het frequenter optreden van extreme weersomstandigheden. Om de productie op peil te houden, is het opnemen van andere gewassen in het bouwplan een optie. Zo kan het onder drogere omstandigheden interessant zijn om gewassen te telen die hier beter tegen bestand zijn, zoals voederbieten en luzerne.

\section{Langetermijn effecten van een ruimer bouwplan}

Uit de berekeningen voor Noordoost-Nederland bleek dat een ruimer bouwplan economisch vaak niet aantrekkelijk is. Hierbij is geen rekening gehouden met eventuele lange-termijn effecten zoals een hogere organische stofaanvoer en een betere bodemgezondheid. Het is lastig dergelijke effecten te kwantificeren. Uit in het verleden uitgevoerde vruchtwisselingsproeven bleek dat opbrengststijgingen als gevolg van verlaging van de teeltfrequentie lang niet altijd leidden tot hogere opbrengsten. Indien dat wel het geval was, lag de opbrengststijging tussen 0 en 5\% (Van Dijk et al., 2012). Uit de literatuur zijn er aanwijzingen voor positieve effecten van aanvoer van organische stof. Uit een analyse van 20 lange-termijnproeven (Hijbeek et al., 2019) bleek dat er gemiddeld geen effect was van organische stoftoevoer op de gewasopbrengst. Voor specifieke gewassen was dit wel het geval. Voor aardappelen werd bijvoorbeeld een positief effect van organische stoftoevoer gevonden van $7 \%$. Verder was het effect van organische stoftoevoer sterker op gronden met een lager kleigehalte, zoals zandgronden.

\section{Perspectief zaadleguminosen}

Uit de berekeningen blijkt dat het financieel saldo van zaadleguminosen wat lager is dan dat van graan, met name wintertarwe. Hierbij is uitgegaan van de huidige opbrengsten en prijzen. Door betere rassen en verdere optimalisatie van de teelt is dit verschil met graan mogelijk te verkleinen. Ook 
kunnen andere aspecten, als de wens voor vermindering van kunstmestgebruik en vervanging van geïmporteerd eiwit door lokaal geteeld eiwit, de positie van deze vlinderbloemige gewassen veranderen.

\section{Combinaties van gewassen}

In het onderzoek zijn geen combinaties van gewassen (mengteelten, bijvoorbeeld stokbonen en snijmaïs) meegenomen. Dergelijke opties worden op dit moment onderzocht, waardoor goede kengetallen nog ontbreken. Het combineren van zaadleguminosen en graan (bijvoorbeeld wintererwten en triticale) is wel een bekende techniek om de teelt van leguminosen te vereenvoudigen.

\section{Onkruidbeheersing}

Zoals eerder aangegeven, is het aspect van onkruidbeheersing in deze studie niet aan de orde geweest. Gezamenlijk grondgebruik kan hier wel invloed op hebben. Zo kan integratie van bouwplannen van een melkveehouder en akkerbouwer leiden tot lagere teeltfrequenties, waardoor gewasgebonden onkruidsoorten mogelijk beter zijn te beheersen. Verder zijn bepaalde onkruidsoorten in het ene gewas gemakkelijker te bestrijden dan in het andere.

Bij grondruil is het tevens van belang na te gaan of aanwezigheid van onkruidsoorten die bij de export van geoogste producten (zoals pootaardappelen) problemen kunnen geven aan de orde is. Een voorbeeld hiervan is knolcyperus. Voor de akkerbouwer is het van belang te weten of dergelijke onkruiden aanwezig zijn op de percelen van het melkveebedrijf. 


\section{Synthese}

In dit hoofdstuk brengen we de resultaten van de verschillende berekeningen bij elkaar om zodoende tot een totaalbeeld te komen. Eerst vatten we de resultaten per onderdeel/thema samen (paragraaf 9.1 en 9.2). Vervolgens gaan we in op het totale beeld, zodat we ook zicht krijgen op trade-offs (paragraaf 9.3).

Bij de bouwplanberekeningen kan onderscheid worden gemaakt tussen enerzijds bouwplanvarianten met betrekking tot gezamenlijk grondgebruik en teelt van eiwitgewassen in de huidige context en anderzijds berekeningen die het effect weergeven van een toekomstige situatie met een veranderd klimaat.

\subsection{Gezamenlijk grondgebruik en teelt van eiwitgewassen}

\subsubsection{Economie}

\section{Melkveehouderij}

Bij gezamenlijk grondgebruik zal in veel gevallen gras deels in de rotatie worden opgenomen op zowel het melkveebedrijf en soms ook op het akkerbouwbedrijf. In de huidige praktijk zien we dat er regelmatig rotaties worden toegepast waarbij relatief lange grasperiodes (4-5 jaar) worden afgewisseld met een bouwlandperiode. Soms duurt de bouwlandperiode maar één jaar. De bouwplanberekeningen hebben laten zien dat met kortere grasperiodes het aandeel blijvend grasland kan worden verhoogd. Ook economisch is dat in veel gevallen gunstig door de lagere kosten voor herinzaai.

Een volledig geïntegreerde rotatie van akkerbouw- en melkveehouderijgewassen met alleen maar tijdelijk grasland geeft een lagere teeltfrequentie van de gewassen, maar verhoogt wel de herinzaaikosten voor gras. In de berekeningen zijn deze volledig aan het melkveebedrijf toegerekend. Dit is ongunstig voor de melkveehouder. Om de samenwerking voor beide partijen aantrekkelijk te houden, is het van belang de kosten en baten zo gelijkmatig mogelijk te verdelen.

In verschillende scenario's is het telen van vlinderbloemigen bekeken. Dit betrof o.a. de teelt van veldbonen die een deel van de snijmaïs verving en vervanging van tijdelijke grasland door gras-rode klaver. De teelt van veldbonen in plaats van maïs was economisch minder gunstig, met name omdat er extra aangekocht voer nodig is, vanwege de behoefte aan extra energie door de lagere VEMproductie van veldbonen. Dit geldt ook indien de maïs wordt vervangen door wintergerst. Waarschijnlijk is het dan gunstiger om de veldbonen of de wintergerst in plaats van gras te telen, met name in situaties waarin er sprake is van een grasoverschot.

Voederbieten zijn qua energie- en eiwitproductie wel gunstig, omdat er kan worden bespaard op aangekocht voer. De teeltkosten zijn wel hoger, maar door de extra besparing op aangekochte voer is er een economisch voordeel.

Het telen van gras-rode klaver in plaats van gras bleek economisch ook gunstig. Dit voordeel was deels een gevolg van lagere kunstmest-N-kosten.

De berekeningen laten ook zien dat naast de VEM- en DVE-productie tevens de VW van het geteelde voer van belang is, met name de verhouding tussen deze parameters. Hoe de teelt van de verschillende gewassen in het bouwplan uitpakt in de economische berekeningen wordt sterk bepaald door de verhouding waarin ze in het bouwplan aanwezig zijn. Dit bepaalt hoeveel melk er geproduceerd kan worden en de hoeveelheid en de samenstelling (eiwit en energie) van het voer dat aangekocht of verkocht dient te worden. 


\section{Akkerbouw}

De berekeningen laten zien dat vervanging van graan door eiwitgewassen (droge erwten, veldbonen en soja) leidt tot een daling van het bouwplansaldo. Bij vervanging van wintertarwe gaf dit een saldodaling van €70-135 per ha (doorgerekend voor regio CEN) en bij vervanging van zomergerst leidde dit tot een daling van $€ 15$ per ha (doorgerekend voor regio NON).

Voor de regio NON is ook een variant doorgerekend met een lagere teeltfrequentie van aardappelen op het akkerbouwbedrijf (1:3 i.p.v. 1:2). In deze variant werden er ook aardappelen op het melkveebedrijf geteeld waardoor er circa $45 \%$ aardappelen in het economisch bouwplan van de akkerbouwer aanwezig waren (i.p.v. $60 \%$ in de referentiesituatie). Hierdoor daalde het bouwplansaldo met circa $€ 250$ per ha. Verdere integratie van het bouwplan van de akkerbouwer en melkveehouder is dan gunstiger, omdat een hoog aandeel aardappelen in het economisch bouwplan dan samengaat met een lagere teeltfrequentie in het perceelbouwplan van de akkerbouw (circa 1:4). Zoals eerder aangegeven, leidt dit wel tot hogere herinzaaikosten bij de melkveehouder.

Voor de regio ZON, waar op akkerbouwbedrijven veel snijmaïs wordt geteeld, is een variant meegenomen waarin de helft van de maïs is vervangen door wintergerst. Dit gaf een iets hoger bouwplansaldo van circa $€ 20$ per ha.

Hoewel op de korte termijn de effecten van teeltverruiming niet gunstig uitpakken kunnen op de lange termijn de effecten gunstiger zijn door een betere bodemgezondheid en/of door een hogere aanvoer van organische stof. Zoals aangegeven in de discussie zijn er aanwijzingen dat een gewas als aardappel positief reageert op een hogere organische stofaanvoer. Bij bodemgezondheid moet worden benadrukt dat naast teeltfrequentie met name ook de gewasvolgorde een belangrijke rol speelt (zie ook hieronder).

\section{Algemeen}

In de berekeningen is in de referentiesituatie al uitgegaan van gezamenlijk grondgebruik, waardoor de economische effecten t.o.v. van een situatie zonder samenwerking niet zichtbaar zijn. Het algemene beeld is dat na het aangaan van de samenwerking op het akkerbouwbedrijf het aandeel aardappelen in het economische bouwplan is verhoogd, meestal ten koste van graan. In vergelijking met de situatie voorafgaand aan de samenwerking geeft dit voor de akkerbouwbouwplannen in deze studie een verhoging van het bouwplansaldo van $€ 250-€ 600$ per ha. Voor de melkveehouder zit het economische voordeel van de samenwerking vooral in de lagere mestafzetkosten. Voor de melkveebedrijven in deze studie loopt het voordeel van bespaarde mestafzetkosten uiteen van $€ 70$ tot $€ 480$ per ha. Benadrukt moet worden dat het voordeel sterk afhangt van de stijging van het aandeel aardappelen (of andere economisch aantrekkelijke gewassen) op het akkerbouwbedrijf en de omvang van het mestoverschot op het melkveebedrijf.

In de periode dat het melkquotum verdween, werden veel samenwerkingen gekenmerkt door een uitruilverhouding van $>1: 1$, waarbij t.o.v. de situatie voorafgaand aan de samenwerking de melkveehouder meer grond op zijn naam kreeg en de akkerbouwer minder (De Wolf et al., 2018). De melkveehouder kon zo meer koeien houden. Door de invoering van het fosfaatquotum is het echter nu moeilijker geworden uit te breiden.

\subsubsection{Nutriëntenoverschot en organische stof}

\section{Nutriënten}

Het telen van vlinderbloemigen, enerzijds via zaadteelt van erwten of veldbonen in plaats van snijmaïs (melkveebedrijf) of wintertarwe (akkerbouwbedrijf) of anderzijds via gras-klaver in plaats van gras, leidt in veel gevallen tot een wat lager $\mathrm{N}$-bodemoverschot. Dit komt door een lager kunstmest-Ngebruik, hoewel dit wel gedeeltelijk wordt vervangen door de biologische N-binding.

Bij vervanging van wintertarwe stijgt het P-bodemoverschot licht door een iets lagere afvoer met geoogst product bij de vlinderbloemigen.

Gezamenlijk grondgebruik kan leiden tot een andere verhouding blijvend en tijdelijk grasland. In de meest ver doorgevoerde situatie, een volledig geïntegreerde rotatie zoals doorgerekend in NON, is er alleen nog maar tijdelijk grasland. Het bodem-N-overschot is in deze situatie lager dan in een minder ver doorgevoerde integratie met meer blijvend grasland. Dat komt door een lager kunstmest- $\mathrm{N}$ - 
gebruik bij de teelt van bouwlandgewassen na gescheurd grasland. Het bemestingsadvies geeft aan dat met name in het eerste jaar na scheuren aanzienlijk kan worden bespaard op de $\mathrm{N}$-bemesting (circa $100 \mathrm{~kg} \mathrm{~N}$ per ha, www.bemestingsadvies.nl). Anderzijds is, volgens het bemestingsadvies, de Nbehoefte van het nieuwe grasland hoger dan van blijvend grasland. De korting na scheuren zou dus idealiter moeten worden gebruikt voor een extra N-bemesting op het nieuwe grasland. Zo lang korting en extra behoefte binnen een bedrijf plaatsvinden, levert dat geen probleem op. Bij gezamenlijk grondgebruik tussen twee bedrijven zullen korting en extra behoefte vaak onevenredig zijn verdeeld binnen de bedrijven. Dit leidt tot een te veel aan gebruiksruimte bij één bedrijf en een tekort bij het andere. Wettelijk mag er geen $\mathrm{N}$ worden verplaatst tussen de bedrijven. Daarnaast is op zand- en lössgrond de N-gewasgebruiksnorm $65 \mathrm{~kg} \mathrm{~N}$ per ha lager indien het gewas wordt geteeld na gescheurd grasland. Dit leidt er toe dat bij meer tijdelijk grasland het $\mathrm{N}$-bodemoverschot lager is door de lagere $\mathrm{N}$-bemesting in het eerste jaar na scheuren. De wettelijke korting op de gebruiksnorm bij gewassen geteeld na het scheuren van gras leidt dan tot een daling van de $\mathrm{N}$-beschikbaarheid op het totale bedrijf.

Wisselbouwsystemen hebben een verhoogd risico van $\mathrm{N}$-uitspoeling. Deze zijn te beperken door een zo hoog mogelijk aandeel blijvend grasland, de duur van de grasperiode in het wisselbouwdeel te beperken, de $\mathrm{N}$-bemesting met name in het eerste jaar na scheuren van het gras aan te passen en daar waar mogelijk nog een vanggewas te telen na het bouwlandgewas.

De bouwplanberekeningen hebben laten zien dat er goede mogelijkheden zijn het aandeel blijvend grasland te verhogen en tegelijkertijd de duur van de grasperiode in het wisselbouwdeel te verlagen.

\section{Organische stof}

Het vervangen van graan door zaadleguminosen gevolgd door een groenbemester op akkerbouwbedrijven heeft slechts geringe gevolgen voor de EOS-aanvoer. Hierbij zijn veldboon en erwten op dit moment gunstiger dan soja. Dat komt, omdat de huidige sojarassen relatief laat worden geoogst in vergelijking met veldboon en erwten en er minder mogelijkheden zijn voor het zaaien van een groenbemester. Verder moet worden benadrukt dat in de berekeningen ervan uitgegaan is dat het graanstro wordt afgevoerd.

Vervanging van maïs door veldbonen of wintergerst op melkveebedrijven had slechts een beperkt effect door het relatief geringe aandeel in het bouwplan (10\%). Op gewasniveau zijn veldbonen en wintergerst duidelijk gunstiger qua organische stofaanvoer dan snijmaïs.

Bij grondruil tussen een akkerbouw- en melkveebedrijf is vaak de vraag welk veevoergewas op het akkerbouwbedrijf wordt geteeld, waarbij vooral de keuze tussen gras of maïs vaak aan de orde is. Bij de regiogesprekken die voorafgaand aan de vaststelling van de bouwplanvarianten zijn gehouden, bleek dat er verschillen zijn tussen de regio's. In drie van de vier regio's (NON, ZON en ZWN) bleek dat maïs vaak op het akkerbouwbedrijf wordt geteeld. In regio ZWN werd als reden genoemd het risico van ritnaalden na een grasperiode. In het centrale zeekleigebied wordt vaak gras op het akkerbouwbedrijf geteeld. Ook op de klei in Noord-Holland bleek in het project Vruchtbare Kringloop Noord-Holland (De Wolf et al., 2018) dat er een sterke voorkeur was voor gras op het akkerbouwbedrijf.

Gras is qua organische stofvoorziening veel gunstiger dan snijmaïs: een jaar gras levert via gewasresten circa $3500 \mathrm{~kg}$ EOS per ha terwijl snijmaïs slechts circa $700 \mathrm{~kg}$ EOS per ha levert, inclusief een vanggewas ruim $1000 \mathrm{~kg}$ EOS per ha. Daarnaast wordt op gras in het algemeen meer dierlijke mest toegediend dan op bouwlandgewassen, waardoor bij opname van gras in de rotatie er ook daardoor extra organische stof wordt aangevoerd. Gras is door het grote aantal bewerkingen echter wel minder een rustgewas is dan bijvoorbeeld graan. Indien de maïs niet wordt geoogst als snijmaïs maar bijvoorbeeld als MKS blijft er veel meer organische stof achter, echter het oogsttijdstip is wel later in de herfst.

Een aandachtspunt rond organische stof is de verhouding blijvend en tijdelijk grasland. In deze studie hebben we rond dit aspect een systematische doorrekening gedaan van de EOS-aanvoer voor verschillende situaties, uiteenlopend van een volledige scheiding van grasland en bouwland tot een situatie met alleen maar tijdelijk grasland. Hieruit bleek dat er geen grote verschillen in de totale EOSaanvoer ontstaan bij een gelijkblijvend bouwplanaandeel en mestgebruik. De organische stofvoorziening wordt voor bouwland gunstiger, waarbij er feitelijk een herverdeling plaatsvindt tussen het melkvee- en akkerbouwbedrijf. 
Naast de aanvoer van organische stof is er de vraag hoe de verhouding blijvend en tijdelijk grasland de koolstofopslag in de bodem beïnvloedt. Het is lastig daar op dit moment een goed beeld van te geven. Experimenten waarin een directe vergelijking plaatsvindt tussen continu gras en bouwland enerzijds en wisselbouw anderzijds zijn schaars, waarbij het beeld is dat de koolstofopslag bij wisselbouw mogelijk wat lager is dan bij volledige scheiding van gras en bouwland. Bij modelberekeningen hangen de uitkomsten weer af van de instelparameters van het model.

\subsubsection{Broeikasgasemissies}

Het aangaan van een samenwerking met gezamenlijk grondgebruik leidt in veel gevallen tot een stijging van het aandeel aardappelen in het economische bouwplan van de akkerbouwer, veelal ten koste van graan. Dit leidt tot een stijging van de BKG-emissies, omdat de BKG-emissies bij aardappelteelt hoger zijn dan bij graanteelt.

Vervanging van graan of maïs door zaadleguminosen heeft een relatief gering effect op de BKGemissies. Deze zijn lager door een lager kunstmest-N-gebruik. Dit geldt met name bij de vergelijking tussen graan en zaadleguminosen.

De keuze voor gras-rode klaver in plaats van gras op het melkveebedrijf leidt tot lagere BKG-emissies, met name door een lager kunstmest-N-gebruik. Inpassing van voederbieten en wintergerst heeft ook een gunstig effect op de BKG-emissies. Dit is vooral een gevolg van lagere voeraankopen.

De verhouding blijvend en tijdelijk grasland heeft slechts een gering effect op de BKG-emissies, waarbij het effect ook nog weer afhangt van de duur van de grasperiode bij het tijdelijke grasland. Bij kortere periodes wordt er vaker gescheurd, waardoor er meer bewerkingen nodig zijn (hoger brandstofverbruik) en de lachgasemissies wat hoger zijn.

\subsubsection{Bodemgezondheid}

Voor het inschatten van het risico van bodemziekten en -plagen is het belangrijk om de uitgangssituatie, dat wil zeggen de aan- of afwezigheid in een perceel, te kennen. De grondsoort is daarbij een indicatie: in het algemeen zijn er meer problemen met ziekten en plagen te verwachten op zand- dan op kleigrond. Een uitzondering zijn cyste- en stengelaaltjes, die ook op zware grond aandacht vergen. Het is van belang om te monitoren welke ziekten en nematoden een probleem in een perceel vormen. Daarnaast is een bemonstering van de grond aan te raden. Deze kennis is van belang om de vruchtwisseling te bepalen om niet een gewas dat een ziekte of plaag sterk vermeerdert te telen vóór de teelt van een gevoelig gewas. Hierbij is naast de teeltfrequentie vooral ook de gewasvolgorde van belang.

De teelt van vlinderbloemigen vormt een risico voor de bodemgezondheid. Vlinderbloemigen zijn gevoelig voor zowel veel schimmelziekten als nematoden en kunnen ze bovendien sterk vermeerderen. Voetziekten, een verzamelnaam voor allerlei schimmelziekten, kunnen zowel op zandals op kleigronden optreden. Een deel van de schimmels, waaronder Sclerotinia sclerotiorum en Verticillium dahliae, en nematoden kunnen ook een probleem vormen in een gevoelige volgteelt zoals aardappel. Sommige bodemschimmels die voetziekten bij vlinderbloemigen veroorzaken, kunnen zeer lange tijd in de bodem overleven. In het algemeen geldt het advies om een ruime vruchtwisseling aan te houden en geen vlinderbloemigen te telen vóór een gevoelig gewas. Er is weinig bekend over de vermeerdering van veel nematodensoorten op rode klaver, maar er worden grote verschillen gevonden in vermeerdering van stengelaaltjes, Sclerotinia en andere bodemschimmels tussen verschillende rode klaverrassen. Het is dus van belang om de raskeuze af te stemmen op de ziekten en plagen die aanwezig zijn in de grond.

Ook bij gezamenlijk grondgebruik van melkveehouders en akkerbouwers is het van belang om rekening te houden met de bodemgezondheid. Wanneer wordt overwogen om veldboon te telen als eiwithoudend gewas, is dit qua bodemziekten eenvoudiger in te passen op een melkveebedrijf dan op een akkerbouwbedrijf. Voor de aardappelteelt is de teelt van gras een risico door vermeerdering van trichodoriden en TRV, maar ook ritnaalden en netschurft. Vanwege de lange levenscyclus vormen ritnaalden een groter risico voor de aardappelteelt bij drie- tot vierjarig grasland dan bij tweejarig grasland. Het verlagen van de teeltfrequentie van aardappel van 1:2 naar 1:3 in NON door samenwerken met een melkveehouder is gunstig voor de aardappelteelt, maar niet voldoende om problemen met aardappelmoeheid te voorkomen. Verlaging van teeltfrequentie biedt wel mogelijkheden door met gewaskeuze rekening te houden met andere nematoden. 
Bij het vervangen van de ene teelt in de rotatie door een andere, hangt het effect op de bodemgezondheid af van de uitgangssituatie. Nematoden die een probleem kunnen vormen en een brede waardplantreeks kennen, zijn M. chitwoodi, M. fallax, P. penetrans en trichodoriden. Afhankelijk van de soorten die in de grond aanwezig zijn, kan de teelt van het ene gewas gunstiger zijn dan het andere. Zo is zomergerst gunstiger bij een besmetting met $M$. fallax, maar Engels raaigras bij een besmetting met $P$. penetrans. De teelt van maïs in plaats van gerst is ongunstiger bij een besmetting met $M$. chitwoodi of $P$. penetrans. Over het probleem van nematoden bij voederbiet is weinig informatie beschikbaar in Aaltjesschema. Wel worden bietencysteaaltjes als aandachtspunt genoemd. Met suikerbiet als referentie, wordt verwacht dat ook voederbiet M. fallax, M. hapla, stengelaaltjes en trichodoriden kan vermeerderen, die een probleem kunnen vormen voor aardappel.

Ook bij de keuze van de groenbemester is het belangrijk om te weten welke nematoden aanwezig zijn. Wanneer $P$. penetrans in hoge dichtheden aanwezig is, kan een zomerteelt van $T$. patula de besmetting nagenoeg saneren. Dit biedt ruimte om bij de gewaskeuze en het opstellen van de vruchtwisseling rekening te houden met de andere nematoden in de grond. Japanse haver vermeerdert $P$. penetrans niet en zorgt daarmee voor een natuurlijke afname, maar geen bestrijding.

Een verandering naar een warmer klimaat met grotere extremen in regenval en droge periodes heeft gevolgen voor het optreden van ziekten en plagen. Sommige zullen daarbij frequenter optreden, terwijl andere minder frequent zullen optreden. Een verandering naar een warmer klimaat met een langer groeiseizoen zal voor sommige soorten nematoden kunnen betekenen dat ze een extra generatie kunnen doorlopen, waardoor de vermeerdering hoger zal zijn dan onder koelere omstandigheden. Dit geldt bij een voldoende vochtvoorziening, hetzij door regenval of door beregenen. Wanneer de temperatuur in de grond boven de $28{ }^{\circ} \mathrm{C} \mathrm{komt}$, dat dit tot gevolg hebben dat resistentie tegen bepaalde ziekten en plagen niet meer werkzaam is, al geldt dit niet voor elke bron van resistentie.

\subsubsection{Overige bedrijfsaspecten}

De bouwplanberekeningen hebben zich beperkt tot de bovengenoemde bedrijfsaspecten. Zo is er niet specifiek gekeken naar de onkruidbeheersing. Gezamenlijk grondgebruik kan hier wel invloed op hebben. Zo kan integratie van bouwplannen van een melkveehouder en akkerbouwer leiden tot lagere teeltfrequenties waardoor gewasgebonden onkruidsoorten mogelijk beter zijn te beheersen. Bij grondruil is het tevens van belang na te gaan of aanwezigheid van onkruidsoorten die bij de export van geoogste producten (zoals pootaardappelen) problemen kunnen geven aan de orde is. Een voorbeeld hiervan is knolcyperus. Voor de akkerbouwer is het van belang te weten of dergelijk onkruiden aanwezig zijn op de percelen van het melkveebedrijf.

\subsection{Klimaatrisico's}

\subsubsection{Eiwitgewassen}

Om de risico's voor eiwitgewassen in kaart te brengen, zijn per gewas (winterveldboon, zomerveldboon, soja, bruine boon, droge erwten) de kwetsbaarheden voor specifieke weersomstandigheden (klimaatfactoren) geïdentificeerd. Zo hebben veel gewassen last van warme en droge periodes in de zomer, of van nachtvorst in het voorjaar. Als deze klimaatfactoren optreden, vindt er opbrengstderving plaats (de impact). Door de klimaatscenario's van het KNMI te gebruiken, kan ingeschat worden hoe vaak deze klimaatfactoren gaan optreden in het toekomstige klimaat (in de periode 2035-2065). Door deze verandering in frequentie te combineren met de impact bij optreden, kan de risico-verandering berekend worden. Dat is in deze studie gedaan door middel van een index, waarin de huidige bruto geldopbrengst op 100 gesteld wordt. Een veranderend klimaatrisico kan de index verhogen (bij een afname in frequentie van de klimaatfactor) of verlagen (bij een toename in de frequentie).

Voor de bestudeerde Eiwitgewassen treedt een wisselend beeld op. Zo gaat de ene index van een klimaatfactor omhoog (>100) en de andere omlaag als gevolg van klimaatverandering. Dat betekent soms een verbetering en soms juist een verslechtering in teeltomstandigheden. De meeste effecten, zelfs in het $\mathrm{W}_{\mathrm{H}}-2050$ scenario met hoge impact, zijn binnen de index bandbreedte van 90 en 110 te vinden, wat geringe veranderingen impliceert. In extreme jaren met waarin meerdere klimaatfactoren optreden, kan de schade in dat jaar hoger uitvallen. 
Eiwitgewassen hebben voornamelijk meer last van droogte en hitte. De frequenties daarvan en daarmee de risico's gaan in de toekomst toenemen (een lagere index dan 100). Vorst in het voorjaar neemt juist af, wat een aantal gewassen sterk ten goede komt. De frequenties van natte periodes tijdens de bloeiperiodes die bladvlekkenziekten veroorzaken, nemen af, waardoor de teeltomstandigheden verbeteren (index wordt groter dan 100). De frequentie van buien met hevige neerslag neemt toe, waardoor gewassen meer last krijgen van water op het land of legering.

\subsubsection{Bouwplannen}

In de standaard gewassen verschilt het effect van klimaatverandering op het risico sterk per gewas, maar ook per klimaatscenario. Aardappel en ui krijgen te maken met grote dalingen in de indexen door toenemende frequenties in hittegolven, droogte en warm en nat weer. Winterwortel en gras ervaren dalingen in de index en daarmee een gering toenemend risico. Maïs, wintertarwe en suikerbiet ervaren gematigde effecten, met stijgende en dalende indexen.

Als we kijken naar het bouwplanniveau wordt duidelijk dat op basis van deze berekeningen de hoog renderende gewassen (aardappel en zaai-ui, en ook winterwortel) in deze berekeningen in de toekomst een groot risico zullen ervaren. De effecten van klimaatverandering op de lager renderende gewassen, zoals gras en wintertarwe, zijn klein. De eiwitgewassen ervaren kleinere risico's dan aardappel, ui en winterwortel. Dat betekent dat als de risicovolle gewassen worden vervangen, of hun teelt-frequentie afneemt door eiwitgewassen toe te voegen, het bouwplanrisico voor

klimaatverandering verlaagd kan worden. Het invoegen van eiwitgewassen ten koste van wintertarwe, suikerbiet, gras of maïs zal niet leiden tot een aanzienlijke verbetering van de situatie (en dus tot een verlaging van het risico), omdat de klimaatrisico's van deze gewassen in het algemeen overeenkomen met die van de eiwitgewassen.

\section{Akkerbouw}

De NON-bouwplanscenario's kenmerken zich door een hoog aandeel poot- en zetmeelaardappelen. Dit maakt deze bouwplannen extra gevoelig voor de verwachte risico's door klimaatverandering. Verder bestaan de bouwplanscenario's voor een kwart uit suikerbieten. Naar verwachting zullen, ondanks de risico's in de winter, de teeltomstandigheden verbeteren. In NON-3 wordt het aandeel van zetmeelaardappelen gedeeltelijk vervangen door zaaiuien. Doordat de indexen van zaaiuien hoger liggen, zal naar verwachting het risico afnemen. In NON-8 wordt een gedeelte van het areaal zomergerst (niet meegenomen in de klimaatstresstest) vervangen door veldbonen. Voor het laatstgenoemde gewas zal door de afname van weersextremen het verwachte risico dalen.

De bouwplanscenario's in CEN bevatten een groot aandeel pootaardappelen en zaaiuien, wat er net als in NON voor zorgt dat de bouwplannen kwetsbaar zijn voor klimaatverandering. Daarnaast bevat CEN ook suikerbieten en wintertarwe, waarvan het toekomstige risico naar verwachting afneemt. CEN bevat daarnaast ook waspeen, maar omdat deze niet is opgenomen in de klimaatstresstest, is hier geen uitspraak over te doen. In CEN-2 verschuift er een gedeelte van het pootaardappelareaal naar wintertarwe, waardoor het toekomstige risico zal dalen. In CEN-5, -6 en -7 verschuift het aandeel pootaardappelen en wintertarwe naar respectievelijk droge erwten, soja en veldboon. Hierdoor zal naar verwachting het toekomstige risico door klimaatverandering dalen.

De bouwplanscenario's in ZWK bevatten een groot aandeel consumptieaardappelen en zaaiuien, wat er net als in de andere regio's voor zorgt dat de bouwplannen kwetsbaar zijn voor klimaatverandering. Daarnaast bevat ZWK ook suikerbieten en wintertarwe, waarvan het toekomstige risico naar verwachting afneemt. De verschuivingen binnen de bouwplanscenario's van ZWK hebben betrekking op het graszaad, wat niet is opgenomen in de klimaatstresstest.

De bouwplanscenario's van ZON bevatten een groot aandeel consumptieaardappelen, wat er net als in de andere regio's voor zorgt dat de bouwplannen kwetsbaar zijn voor klimaatverandering. Daarnaast bestaan de bouwplannen uit snijmaïs, suikerbiet, doperwten en stamslabonen en waspeen. Het toekomstige risico van snijmaïs en suikerbiet zal naar verwachting afnemen. De overige gewassen zijn niet meegenomen in de klimaatstresstest.

\section{Melkveehouderij}

Binnen alle beschouwde regio's bestaat het bouwplan van de melkveebedrijven voornamelijk uit grasland (blijvend of tijdelijk) en snijmaïs. De andere gewassen zijn niet meegenomen in de klimaatstresstest. Het verwachte toekomstige risico van snijmaïs zal, zoals uit de bovenstaande 
indexen blijkt, dalen. Grasland echter zal onder het $\mathrm{GL}_{\mathrm{L}}$-scenario en vooral het $\mathrm{W}_{\mathrm{H}}$-scenario te maken krijgen met een iets verhoogd risico van droogte en warmte.

\subsection{Integraal beeld en conclusies/adviezen}

In Tabel 9.1 is een globaal overzicht gegeven van de effecten van bouwplanaanpassingen op verschillende bedrijfsaspecten. Hierbij moet worden benadrukt dat de kleuren zijn gebaseerd op de uitkomsten van de bouwplanberekeningen en dus afhangen van de daar aangenomen uitgangspunten. Het betreft ook veelal een gemiddelde situatie. De tabel laat zien dat dat geen van de bekeken bouwplanveranderingen een positief effect heeft op alle aspecten. Wel zijn er perspectieven voor verschillende aanpassingen ook als toekomstige klimaatveranderingen in beschouwing worden genomen. Hieronder worden de belangrijkste conclusies weergegeven.

\section{Gezamenlijk grondgebruik}

- $\quad$ Uit de studie blijkt dat bij gezamenlijk grondgebruik veel bedrijfsaspecten een rol spelen. Dit vereist een goede voorbereiding bij het opzetten van de samenwerking en met name de vruchtopvolging dient goed doordacht te worden. Voor de akkerbouwer verdienen vooral bodemgezondheidsaspecten de aandacht, met name bij de teelt van gewassen voor de export. Hierbij is naast de teeltfrequentie vooral ook de gewasvolgorde van belang. Kennis van de in een perceel aanwezige bodemziekten en -plagen is noodzakelijk om een slimme gewasvolgorde te bepalen.

- $\quad$ Bij de overwegingen voor een ruimer bouwplan via integratie met melkveehouderijgewassen verdienen naast de korte termijn effecten (o.a. economie) ook de langere termijn effecten (o.a. organische stof, bodemgezondheid) de aandacht.

- Het integreren van grasland met akkerbouw is gunstig voor de organisch stofvoorziening van het bouwland. Om trade-offs te voorkomen is bij de inrichting van de wisselbouw het volgende van belang:

- Uit oogpunt van bodemgezondheid (o.a. ritnaalden) en risico van N-verliezen heeft het kiezen voor korte grasperiodes (maximaal 2-3 jaar oud) de voorkeur. Afhankelijk van de vormgeving van de rotatie kan dit leiden tot hogere herinzaaikosten. De berekeningen hebben echter laten zien dat, indien het aandeel blijvend grasland zo hoog mogelijk wordt gehouden, de kosten beperkt zijn.

- In de bouwlandperiode is het van belang dat er na het scheuren van het gras een gewas wordt geteeld met een hoge $\mathrm{N}$-behoefte (bijvoorbeeld voederbieten, consumptie- en zetmeelaardappelen en maïs) en dat de $\mathrm{N}$-bemesting wordt aangepast aan de te verwachten nalevering uit de gescheurde zode (circa $100 \mathrm{~kg} \mathrm{~N}$ per ha). Om de risico's van N-verliezen verder te beperken zou bij voorkeur ook nog een vanggewas moeten worden gezaaid

\section{Teelt van alternatieve (eiwit) gewassen}

- $\quad$ De teelt van zaadleguminosen op akkerbouwbedrijven is op dit moment economisch ongunstiger dan graan, vooral als gevolg van een lagere financiële opbrengst. Wel geeft het een verlaging van het kunstmest-N-gebruik en zijn de broeikasgasemissies lager.

- Op melkveebedrijven was de teelt van gras-rode klaver (in plaats van gras) economisch gunstiger dan de teelt van veldbonen (in plaats van een deel van de maïs). Gras-rode klaver leidt tot een sterkere verlaging van het kunstmest- $\mathrm{N}$-gebruik en sterkere daling van de broeikasgasemissies.

- Vervanging van maïs door voederbieten is economisch gunstiger dan vervanging van maïs door veldbonen. Ook de broeikasgasemissies waren lager indien de maïs werd vervangen door voederbieten door de besparing op aangekocht mengvoer.

- $\quad$ Bij toekomstige bouwplanverkenningen op melkveebedrijven is het beter eerst na te gaan wat gegeven de randvoorwaarden het meest optimale rantsoen is en vervolgens na te gaan hoe en waar het voer het beste kan worden geteeld.

\section{Klimaatverandering}

- De gevolgen van toenemende frequenties in hittegolven, droogte en warm en nat weer zijn het grootst voor aardappel en ui. Bij winterpeen en gras zijn de risico's geringer, terwijl bij maïs, wintertarwe en suikerbiet de effecten soms positief zijn en soms negatief. Dit betekent dat bij bouwplannen met een hoog aandeel aardappelen en uien de gevolgen van klimaatverandering het grootst zijn. 
- $\quad$ Eiwitgewassen (zaadleguminosen) hebben voornamelijk meer last van droogte en hitte. De frequenties daarvan, en daarmee de risico's, gaan in de toekomst toenemen. De risico's van vorst in het voorjaar en natte periodes tijdens de bloei nemen af, waardoor de teeltomstandigheden verbeteren. Door de hogere frequentie van buien met hevige neerslag kunnen de gewassen wel meer last krijgen van water op het land of legering. 
Tabel 9.1 Overzicht van effecten van bouwplanaanpassingen op verschillende bedrijfsaspecten.

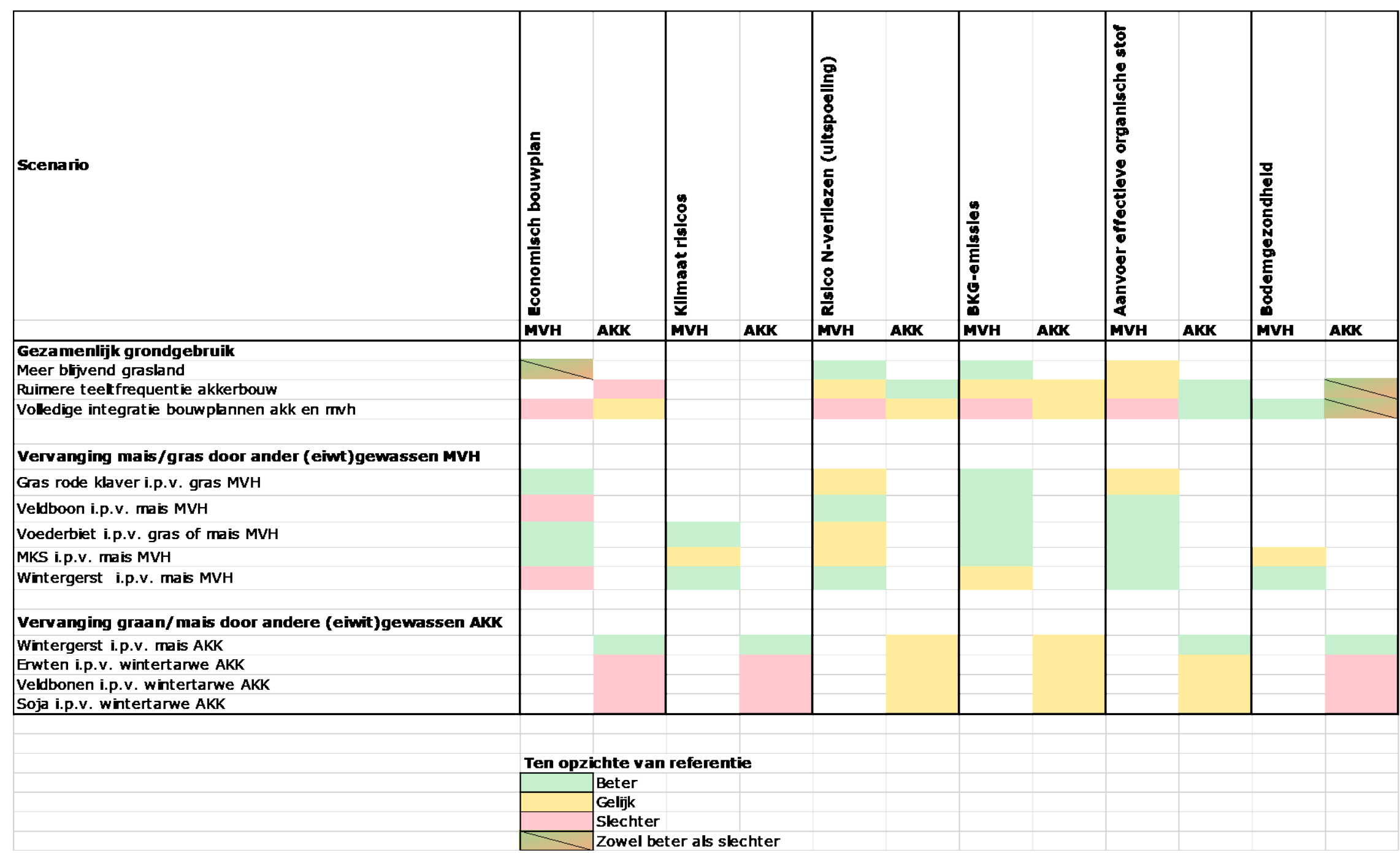




\section{Literatuur}

Aaltjesschema, 2020. https://www.aaltjesschema.nl (geraadpleegd diverse keren maart-augustus 2020).

Agris, 2000. Netschurft. http://www.agris.be/nl/aardappelziekte/194026.asp (geraadpleegd 18-082020).

Attema, J., Bakker, A. Beersma, J. Bessembinder, J. Boers, R. Brandsma, T. ... \& W. Hazeleger, 2014. Knmi'14: Climate change scenarios for the 21st century-A netherlands perspective. KNMI: De Bilt, The Netherlands.

Best4Soil. www.Best4Soil.eu

Bikker, P., M.M. v. Krimpen \& G.J. Remmelink, 2011. Stikstofverteerbaarheid in voeders voor landbouwhuisdieren : berekeningen voor de TAN-excretie. Werkdocument / Wettelijke Onderzoekstaken Natuur \& Milieu ; 224. Wettelijke Onderzoekstaken Natuur \& Milieu, Wageningen.

Bakker, A., \& J. Bessembinder, 2012. Time Series Transformation Tool: Description of the Program to Generate Time Series Consistent with the KNMI'60 Climate Scenarios. KNMI.

Brolsma, K., E. Ton \& A. Reijneveld, 2017. Bodemvruchtbaarheid in Nederland over de periode 2005 2015. Trends in de chemische, de fysische en de biologische bodemvruchtbaarheid per LEI gebied voor elke grondsoort en per sector. Eurofins Agro.

Commissie Grondgebondenheid, 2018. Grondgebondenheid als basis voor een toekomstbestendige melkveehouderij.

Conijn, J.G. \& J.P. Lesschen, 2015. Soil organic matter in the Netherlands; Quantification of stocks and flows in the top soil. Wageningen, PRI report 619 / Alterra report 2663. 68 pp.

CVB, 2018. Tabellenboek Veevoeding 2018 [Feedstuffs table 2018]. FND, Wageningen, Nederland.

De Wit, J., D. Swart \& E. Luijendijk, 2009. Klimaat en landbouw Noord- Nederland : ' effecten van extremen', 112.

Eekeren, van N. et al., 2008. Soil biological quality after 36 years of ley-arable cropping, permanent grassland and permanent arable cropping. Applied soil ecology 40: 432-446.

Hajihassani, A., M. Tenuta \& R.H. Gulden, 2017. Influence of temperature on development and reproduction of Ditylenchus weischeri and D. dipsaci on Yellow Pea. Plant Disease, 101(2), 297305.

Heyman, F., J.E. Blair, L. Persson \& M. Wikström, 2013. Root rot of pea and faba bean in Southern Sweden caused by Phytophthora pisi sp. nov. Plant Disease, 97(4), 461-471.

Hijbeek R., M.K. van Ittersum, H.F.M. ten Berge, G. Gort, H. Spiegel \& A.P. Whitmore, 2016. Do organic inputs matter - a meta-analysis of additional yield effects for arable crops in Europe. Plant Soil (2017) 411:293-303. DOI 10.1007/s11104-016-3031-x.

Hurk, B. van den, A. Klein Tank, G. Lenderink, A. van Ulden, G.J. Van, C. Katsman, ... \& W. Hazeleger, 2006. KNMI Climate Change Scenarios 2006 for the Netherlands KNMI Scientific Report WR 200601.

Hurk, B. van den., P. Siegmund \& A. Klein Tank, 2014. KNMI'14: climate change scenarios for the 21st Century-a Netherlands perspective. KNMI scientific report (WR 2014-01). 
Jones, L.M., A.K. Koehler, M. Trnka, J. Balek, A.J. Challinor, H.J. Atkinson \& P.E. Urwin, 2017. Climate change is predicted to alter the current pest status of Globodera pallida and G. rostochiensis in the United Kingdom. Global Change Biology, 23(11), 4497-4507.

Juroszek, P. \& A. von Tiedemann, 2011. Potential strategies and future requirements for plant disease management under a changing climate. Plant Pathology, 60(1), 100-112.

Klein Tank, A., J. Beersma, J. Bessembinder, B. van den Hurk \& G. Lenderink, 2015. Klimaatscenario's KNMI '14. Retrieved from www.klimaatscenarios.nl

Lamers, J., K. van Rozen \& B. Hanse, 2016. Het bodemschimmelschema: vernieuwd schema, 2016. Wageningen: Praktijkonderzoek Plant \& Omgeving, onderdeel van Wageningen UR, Business Unit PPO-AGV.

Lecat, A., 2005. Praktijkgids biologische akkerbouw : valorisatie grensoverschijdende ervaringskennis in de biologische landbouw. (A. Lecat, Ed.). Christine Boutin.

Leeuwen-Haagsma, W.K. van, H. Hoek, L.P.G. Molendijk, L. Mommer, J. Ulen, B.M.A. KroonenBackbier \& G.A. de Groot, 2019. Handboek Groenbemesters 2019. Wageningen: Wageningen University \& Research.

Levenfors, J.P., M. Wikström, L. Persson \& B. Gerhardson, 2003. Pathogenicity of Aphanomyces spp. from different leguminous crops in Sweden. European Journal of Plant Pathology, 109(6), 535543.

Lowe, M., R. Kelly, L. Skøt \& K.A. Mizen, 2014. Disease resistance in red clover (Trifolium pratense L.) to stem nematodes and Sclerotinia. In A. Hopkins, R. P. Collins, M. D. Fraser, V. R. King, D. C. Lloyd, J. M. Moorby, \& P. R. H. Robson (Eds.), EGF at 50: The future of European grasslands. Proceedings of the 25th General Meeting of the European Grassland Federation, Aberystwyth, Wales, 7-11 September 2014. Aberystwyth; UK: IBERS, Aberystwyth University.

Luck, J., M. Spackman, A. Freeman, P. Trebicki, W. Griffiths, K. Finlay \& S. Chakraborty, 2011. Climate change and diseases of food crops. Plant Pathology, 60(1), 113-121.

Mandersloot, F., 1989. Simulatie van voeding en groei van jongvee : toelichting op een computerprogramma. 1e dr. ed. Rapport / Proefstation voor de Rundveehouderij, Schapenhouderij en Paardenhouderij te Lelystad, 0169-3689 ; nr. 116. Proefstation voor de Rundveehouderij, Schapenhouderij en Paardenhouderij (Waiboerhoeve, Regionale Onderzoek Centra), Lelystad.

Mizukubo, T. \& H. Adachi, 1997. Effect of temperature on Pratylenchus penetrans development. Journal of Nematology, 29(3), 306-314.

Moretti, A., M. Pascale \& A.F. Logrieco, 2019. Mycotoxin risks under a climate change scenario in Europe. Trends in Food Science \& Technology, 84, 38-40.

Newton, A.C., L. Torrance, N. Holden, I.K. Toth, D.E.L. Cooke, V. Blok \& E.M. Gilroy, 2012. Climate Change and Defense against Pathogens in Plants. In S. Sariaslani \& G. M. Gadd (Eds.), Advances in Applied Microbiology (Vol. 81, pp. 89-132).

Oyarzun, P.J., 1991. Biotoets voetziekten in erwten. Lelystad: PAGV.

Pokorný, R., B. Andersson, J. Nedelník \& P. Ríha, 2003. Current state of red clover breeding for resistance in central and northern Europe. Czech Journal of Genetics and Plant Breeding, 39(Special issue), 82-85.

Pondini, L., 2017. The effects of change in extreme climate events on agriculture in the Netherlands, (August).

Prins, U. \& M. van Krimpen, 2007. Handboek Peulvruchten voor krachtvoer. Driebergen: Louis Bolk Instituut.

Qiu, Y.T., K. Rozen, E. van Raaijmakers \& T. Everaarts, 2013. Begeleidende rapportage Schema Bodemplagen. Wageningen: Praktijkonderzoek Plant \& Omgeving, onderdeel van Wageningen UR, Business Unit PPO-AGV. 
Quillévéré-Hamard, A., G.I. Roy, A. Moussart, A. Baranger, D. Andrivon, M.L. Pilet-Nayel \& C.I. May, 2018. Genetic and pathogenicity diversity of Aphanomyces euteiches populations from peagrowing regions in France. Frontiers in plant science, 9(November). doi:dx.doi.org/10.3389/fpls.2018.01673

Rubiales, D., S. Fondevilla, W.D. Chen, L. Gentzbittel, T.J.V. Higgins, M.A. Castillejo, . . . N. Rispail, 2015. Achievements and challenges in legume breeding for pest and disease resistance. (Special Issue: Legumes in sustainable agriculture.). Critical Reviews in Plant Sciences, 34(1/3), 195-236.

Santo, G. S., \& J.H. O'Bannon, 1981. Effect of soil temperature on the pathogenicity and reproduction of Meloidogyne chitwoodi and M. hapla on Russet Burbank potato. Journal of Nematology, 13(4), 483-486.

Schaap, B.F., M. Blom-Zandstra, C.M. Hermans, B.G. Meerburg \& J. Verhagen, 2011. Impact changes of climatic extremes on arable farming in the north of the Netherlands. Regional Environmental Change, 11(3), 731-741. https://doi.org/10.1007/s10113-011-0205-1

Schans, D.A. van der (1998). Teelthandleiding luzerne. Lelystad: Praktijkonderzoek voor de Akkerbouw en de Vollegrondsgroenteteelt.

Schomaker, C.H., 2008. Onderzoek oude literatuur stengelaaltjes. Wageningen: Plant Research International.

Seidel, P., 2016. Extreme weather events and their effects on plant pests infesting wheat, barley and maize. [Extremwetterereignisse und ihre Auswirkungen auf Schaderreger in Weizen, Gerste und Maïs. ]. Journal für Kulturpflanzen, 68(11), 313-327.

Timmer, R., 2020. Interviews eiwitgewassen.

Van der Voort, M., 2018. KWING AGV. Lelystad: Wageningen Plant Research.

Van Dijk, W., J. Spruijt, W. Runia \& W.C.A. van Geel, 2012. Verruiming vruchtwisseling in relatie tot mineralenbenutting, bodemkwaliteit en bedrijfseconomie op akkerbouwbedrijven.

Praktijkonderzoek Plant en Omgeving, publicatie nr. 527.

Van Dijk, W., M.W.J. Stienezen, R.L.M. Zom \& R.Y. van der Weide, 2020. Verkenning vruchtwisselingsopties met voedergewasssen op melkveebedrijven. Wageningen Research, Rapport WPR-844.

Van Dijk, W., J.J. Schröder, L.B. Šebek, J. Oenema, J.G. Conijn, T.V. Vellinga, J. de Boer, M.H.A. de Haan \& J. Verloop, 2020. Rekenregels van de KringloopWijzer 2019 : achtergronden van BEX, BEA, BEN, BEP en BEC: actualisatie van de 2018-versie. Stichting Wageningen Research, Wageningen Plant Research, Business unit Agrosystems Research, Wageningen.

Vellinga, Th.V. et al., 2004. The impact of grassland ploughing on CO2 and N2O emissions in the Netherlands. Nutrient Cycling in Agroecosystems 70: 33-45.

Verdejo-Lucas, S., M. Blanco, L. Cortada \& F.J. Sorribas, 2013. Resistance of tomato rootstocks to Meloidogyne arenaria and Meloidogyne javanica under intermittent elevated soil temperatures above $28^{\circ} \mathrm{C}$. Crop Protection, 46, 57-62.

Verloop, J. et al., 2015. Organic matter dynamics in an intensive dairy production system on a Dutch Spodosol. Geoderma 237-238: 159-167.

Verstand, D., B. Schaap, H. Schoorlemmer, P. de Wolf, D. van Balen \& J. Verhagen, 2020. Klimaatadaptatie in de open teelten : Inventarisatie van klimaattrends, risico's en adaptatiemaatregelen voor boerenbedrijven inde open teelten. https://doi.org/10.18174/515383.

Visie Grondgebondenheid Melkveehouderij, 2018. Grondgebondenheid als basis voor een toekomstbestendige melkveehouderij. Advies Commissie Grondgebondenheid.

Winfield, A.L. \& D.A. Cooke, 1975. The ecology of Trichodorus. In F. Lamberti \& J.W. Seinhorst (Eds.), Nematode vectors of plant viruses (pp. 309-340). London, New York: Plenum Press. 
Yadav, S.S., D.L. McNeil, R. Redden \& S.A. Patil, (Eds.), 2010. Climate change and management of cool season grain legume crops. Dordrecht e.a.: Springer.

Zom, R.L.G., 2014. The development of a model for the prediction of feed intake and energy partitioning in dairy cows. Wageningen University, Wageningen.

Zom, R.L.G., G. André \& A.M. van Vuuren, 2012a. Development of a model for the prediction of feed intake by dairy cows 2. Evaluation of prediction accuracy. Livest. Sci. 143(1):58-69.

Zom, R. L.G., G. André \& A.M. van Vuuren, 2012b. Development of a model for the prediction of feed intake by dairy cows: 1 . Prediction of feed intake. Livest. Sci. 143(1):43-57. 


\section{Bijlage 1 Deelnemers regiogesprekken}

\section{Regio Noordoost-Nederland (NON)}

Frank Mensen, adviseur akkerbouw Johan Schuitema

Jelmer Hensens, adviseur melkveehouderijteelten Johan Schuitema

Johan Specken, regio onderzoeker WUR Noordoost-Nederland

\section{Regio Zuidoost Nederland (ZON)}

Jan van Middelaar, adviseur PPP Agro Advies

Marc Kroonen, bedrijfsleider proefbedrijf Vredepeel (WUR)

\section{Regio Centrale zeeklei (CEN)}

Jaap Gielen, specialist melkveehouderij Countus

Niek Vedelaar, adviseur Delphy

Jacob de Jong, bedrijfsleider WUR Open Teelten Lelystad

\section{Regio Zuidwest-Nederland (ZWN)}

Mark de Beer, adviseur Agrocontrol)

Edwin Kleijwegt, adviseur van Iperen

Marcel Tramper, bedrijfsleider proefbedrijf Westmaas (WUR) 


\section{Bijlage 2 Definities afkortingen klimaatfactoren}

\begin{tabular}{|c|c|}
\hline Klimaatfactor & Meteorologische definitie \\
\hline WP-1 & Minimaal $75 \%$ van de 14 dagen met een dagelijkse neerslag $\geq 2 \mathrm{~mm}$ \\
\hline WP-2 & Minimaal $75 \%$ van 14 dagen met een dagelijkse neerslag $\geq 0,5 \mathrm{~mm}$ \\
\hline WP-3 & Ten minste $75 \%$ van 21 dagen met een dagelijkse neerslag $\geq 0,5 \mathrm{~mm}$ \\
\hline WP-4 & Minimaal 1 dag met neerslag $\geq 25 \mathrm{~mm}$ \\
\hline $\mathrm{F}-1$ & Minimaal 1 dag met een minimumtemperatuur $\leq-3^{\circ} \mathrm{C}$ \\
\hline $\mathrm{F}-2$ & Minimaal 1 dag met een minimumtemperatuur $\leq-5^{\circ} \mathrm{C}$ \\
\hline $\mathrm{F}-3$ & Minimaal 3 dagen met een minimumtemperatuur $\leq-5^{\circ} \mathrm{C}$ \\
\hline W-1 & Minimaal 3 dagen $\geq 30^{\circ} \mathrm{C}$ in een periode van minimaal 5 dagen $\geq 25^{\circ} \mathrm{C}$ \\
\hline D-1 & Droge periode van minimaal 21 dagen met een neerslag $\leq 5 \mathrm{~mm}$ \\
\hline$D-W-1$ & $\begin{array}{l}\text { Droge periode van minimaal } 21 \text { dagen met een neerslag } \leq 5 \mathrm{~mm} \text { en minimaal } 14 \text { opeenvolgende dagen } \\
\text { met een maximumtemperatuur } \geq 20 \mathrm{C}\end{array}$ \\
\hline C-D-1 & Gemiddelde temperatuur $\leq 13^{\circ} \mathrm{C}$ en een droge periode van minimaal 14 dagen met neerslag $\leq 5 \mathrm{~mm}$ \\
\hline D-W-2 & $\begin{array}{l}\text { Minimaal } 3 \text { dagen } \geq 30^{\circ} \mathrm{C} \text { in een periode van minimaal } 5 \text { dagen } \geq 25^{\circ} \mathrm{C} \text { en een droge periode van } \\
\text { minimaal } 21 \text { dagen met een neerslag } \leq 5 \mathrm{~mm}\end{array}$ \\
\hline WP-10 & Dagelijkse neerslag $\geq 45 \mathrm{~mm}$ \\
\hline WP-5 & Dagelijkse neerslag $\geq 45 \mathrm{~mm}$ of in 3 dagen $\geq 60 \mathrm{~mm}$ \\
\hline D-2 & Minimaal 30 dagen met een neerslagsom $\leq 5 \mathrm{~mm}$ \\
\hline D-3 & Minimaal 30 dagen met een neerslagsom $\leq 10 \mathrm{~mm}$ \\
\hline WP-6 & Dagelijkse neerslag van $\geq 45 \mathrm{~mm}$ of in 8 dagen $\geq 100 \mathrm{~mm}$ \\
\hline $\mathrm{F}-4$ & Minimaal 1 dag met een minimumtemperatuur $\leq-2^{\circ} \mathrm{C}$ \\
\hline D-4 & Minimaal 40 dagen met een neerslagsom $\leq 10 \mathrm{~mm}$ \\
\hline D-5 & Minimaal 10 dagen met een neerslagsom $\leq 5 \mathrm{~mm}$ \\
\hline W-3 & Minimaal 3 dagen met een maximumtemperatuur $\geq 30^{\circ} \mathrm{C}$ \\
\hline W-4 & Minimaal 3 dagen met een maximumtemperatuur $\geq 40^{\circ} \mathrm{C}$ \\
\hline W-5 & Minimaal 3 dagen in een periode van 5 dagen met een maximumtemperatuur $\geq 40^{\circ} \mathrm{C}$ \\
\hline W-2 & Minimaal 14 dagen met een maximumtemperatuur $\geq 10^{\circ} \mathrm{C}$ \\
\hline W-6 & Minimaal 14 dagen met een maximumtemperatuur $\geq 30^{\circ} \mathrm{C}$ \\
\hline W-WP-1 & Minimaal $66 \%$ van 3 opeenvolgende dagen met maximumtemperatuur $\geq 30^{\circ} \mathrm{C}$ en neerslag $\geq 0,5 \mathrm{~mm}$ \\
\hline WP-7 & Minimaal $10 \%$ van 28 dagen met een neerslagpercentage $\geq 10 \mathrm{~mm}$ \\
\hline W-WP-2 & $\begin{array}{l}\text { Minimaal } 14 \text { dagen met een maximumtemperatuur } \geq 20^{\circ} \mathrm{C} \text { en gedurende } 50 \% \text { van de dagen een } \\
\text { neerslag } \geq 0,5 \mathrm{~mm}\end{array}$ \\
\hline $\mathrm{F}-5$ & $\begin{array}{l}\text { Periode van minimaal } 3 \text { dagen herhaalde vorst en ontdooien (minimum } \leq-1^{\circ} \mathrm{C} \text { en maximum } \geq 1^{\circ} \mathrm{C} \text { ) na } \\
\text { periode van sterke vorst (minimum } \leq-10^{\circ} \mathrm{C} \text { ), incl. een overgangsperiode van } 2 \text { dagen naar ontdooien. }\end{array}$ \\
\hline WP-8 & Dagelijkse neerslag $\geq 25 \mathrm{~mm}$ of in 3 dagen $\geq 60 \mathrm{~mm}$ \\
\hline W-7 & Minimaal 2 dagen met een maximumtemperatuur $\geq 35^{\circ} \mathrm{C}$ \\
\hline WP-9 & Dagelijkse neerslag $\geq 25 \mathrm{~mm}$ of in 8 dagen $\geq 100 \mathrm{~mm}$ \\
\hline F-6 & Minimaal 1 dag met een minimumtemperatuur $\leq-20^{\circ} \mathrm{C}$ \\
\hline
\end{tabular}




\section{Bijlage 3 Emissies melkkoeien}

\begin{tabular}{|c|c|c|c|c|c|}
\hline 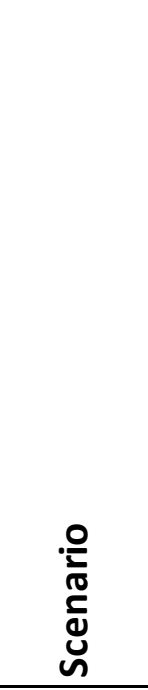 & 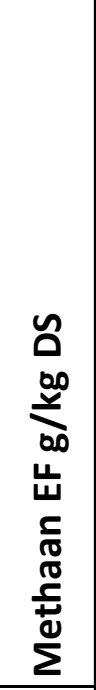 & 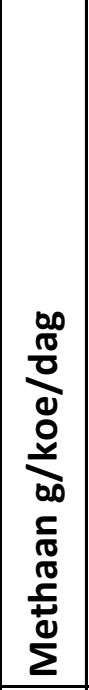 & 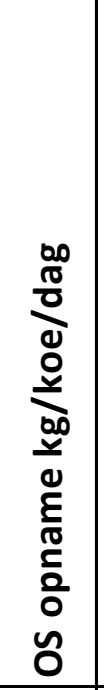 & 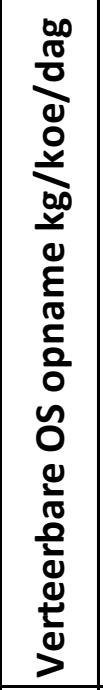 & 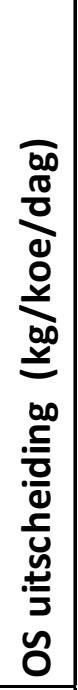 \\
\hline NON-1 & 20,9 & 442 & 19,5 & 16,9 & 2,9 \\
\hline NON-2 & 20,9 & 442 & 19,5 & 16,9 & 2,9 \\
\hline 3 & 20,9 & 442 & 19,5 & 16,9 & 2,9 \\
\hline NON-4 & 20,9 & 442 & 19,5 & 16,9 & 2,9 \\
\hline NON-5 & 21,6 & 460 & 19,4 & 17,3 & 2,5 \\
\hline NON-6 & 21,1 & 457 & 19,9 & 17,6 & 2,6 \\
\hline NON-7 & 21,1 & 457 & 19,9 & 17,6 & 2,6 \\
\hline NON-8 & 20,9 & 442 & 19,5 & 16,9 & 2,9 \\
\hline CEN & 1,3 & 467 & 20,3 & 17,7 & 2,9 \\
\hline CEN & & & & & \\
\hline CEN-3 & 21,3 & 467 & 20,3 & 17,7 & 2,9 \\
\hline CE & & & & & \\
\hline $\mathrm{CH}_{2}$ & & & & & \\
\hline- & & & & & \\
\hline CFN-7 & L,3 & 470 & 20,1 & 17,1 & 3,4 \\
\hline & 21,4 & 483 & 20,8 & 18,2 & 2,9 \\
\hline & & & & & \\
\hline & 1,2 & 457 & 19,9 & 17,6 & 2,6 \\
\hline Wot & 1,1 & 448 & 19,4 & 17,3 & 2,5 \\
\hline $\mathrm{ZC}$ & 1,0 & 442 & 19,4 & 16,9 & 2,8 \\
\hline ZON & 21,0 & 442 & 19,4 & 16,9 & 2,8 \\
\hline & 21,0 & 442 & 19,4 & 16,9 & 2,8 \\
\hline ZON-4 & 21,0 & 442 & 19,4 & 16,9 & 2,8 \\
\hline ZON-4a & 20,9 & 440 & 19,6 & 16,8 & 3,2 \\
\hline $\mathrm{V}-5$ & 21,2 & 463 & 19,7 & 16,7 & 3,4 \\
\hline $\mathrm{V}-6$ & 21,4 & 448 & 19,1 & 17,1 & 2,3 \\
\hline ZON-7 & 20,9 & 438 & 19,4 & 16,8 & 2,9 \\
\hline
\end{tabular}




\section{Bijlage $4 \quad \mathrm{~N}$ benutting excretie melkkoeien}

\begin{tabular}{|c|c|c|c|c|c|c|c|c|c|c|c|}
\hline 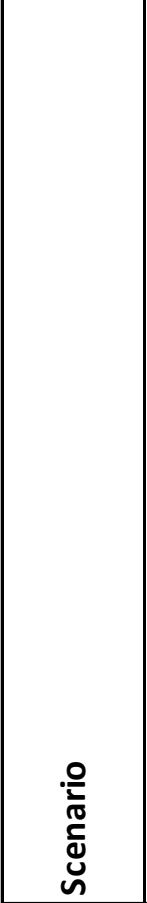 &  & 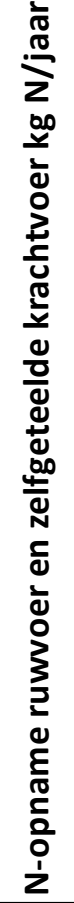 & 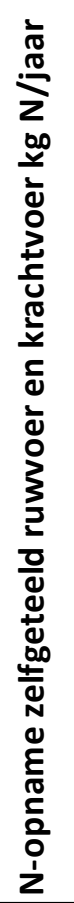 & 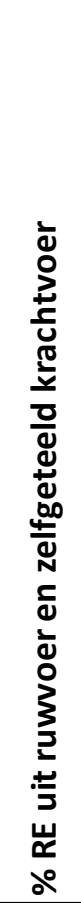 & 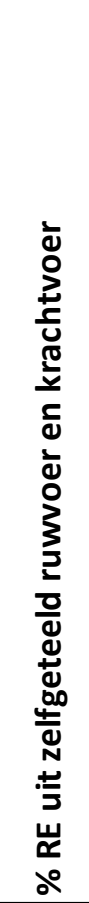 &  & 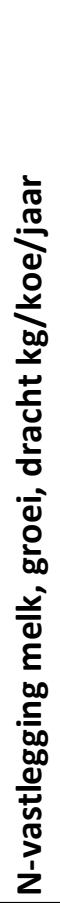 &  & 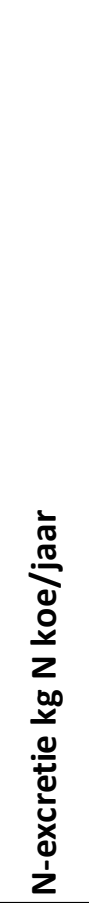 & 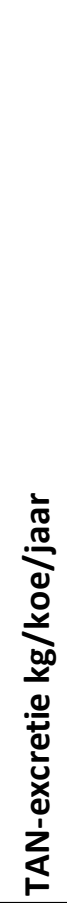 & 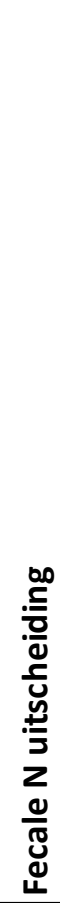 \\
\hline NON-1 & 78 & 105 & 105 & 57,2 & 57,2 & 183 & 56 & 27,9 & 126 & 68 & 59 \\
\hline NON-2 & 78 & 105 & 105 & 57,2 & 57,2 & 183 & 56 & 27,9 & 126 & 68 & 59 \\
\hline NON-3 & 78 & 105 & 105 & 57,2 & 57,2 & 183 & 56 & 27,9 & 126 & 68 & 59 \\
\hline NON-4 & 78 & 105 & 105 & 57,2 & 57,2 & 183 & 56 & 27,9 & 126 & 68 & 59 \\
\hline NON-5 & 58 & 110 & 110 & 65,5 & 65,5 & 168 & 56 & 21,4 & 111 & 68 & 43 \\
\hline NON-6 & 77 & 126 & 124 & 62,0 & 61,3 & 203 & 56 & 28,3 & 147 & 89 & 58 \\
\hline NON-7 & 77 & 126 & 124 & 62,0 & 61,3 & 203 & 56 & 28,3 & 147 & 89 & 58 \\
\hline NON-8 & 78 & 105 & 105 & 57,2 & 57,2 & 183 & 56 & 27,9 & 126 & 68 & 59 \\
\hline CEN-1 & 88 & 99 & 99 & 53,1 & 53,1 & 187 & 58 & 32,8 & 129 & 63 & 65 \\
\hline \multicolumn{12}{|l|}{ CEN-2 } \\
\hline CEN-3 & 88 & 99 & 99 & 53,1 & 53,1 & 187 & 58 & 32,8 & 129 & 63 & 65 \\
\hline \multicolumn{12}{|l|}{ CEN-4 } \\
\hline \multicolumn{12}{|l|}{ CEN-5 } \\
\hline \multicolumn{12}{|l|}{ CEN-6 } \\
\hline CEN-7 & 92 & 99 & 99 & 51,8 & 51,8 & 191 & 57 & 33,3 & 134 & 65 & 69 \\
\hline ZWN-1 & 76 & 113 & 113 & 59,7 & 59,7 & 189 & 58 & 31,2 & 132 & 76 & 56 \\
\hline \multicolumn{12}{|l|}{ ZWN-2 } \\
\hline ZWN-3 & 79 & 110 & 110 & 58,3 & 58,3 & 189 & 58 & 31,0 & 131 & 73 & 58 \\
\hline ZWN-4 & 78 & 114 & 114 & 59,2 & 59,2 & 192 & 57 & 31,3 & 135 & 77 & 58 \\
\hline ZON-1 & 81 & 104 & 99 & 56,1 & 54,6 & 185 & 57 & 28,7 & 128 & 67 & 61 \\
\hline ZON-2 & 81 & 104 & 99 & 56,1 & 54,6 & 185 & 57 & 28,7 & 128 & 67 & 61 \\
\hline ZON-3 & 81 & 104 & 99 & 56,1 & 54,6 & 185 & 57 & 28,7 & 128 & 67 & 61 \\
\hline ZON-4 & 81 & 104 & 99 & 56,1 & 54,6 & 185 & 57 & 28,7 & 128 & 67 & 61 \\
\hline ZON-4a & 80 & 98 & 79 & 55,1 & 49,9 & 178 & 57 & 25,5 & 121 & 60 & 61 \\
\hline ZON-5 & 92 & 104 & 104 & 53,0 & 53,0 & 196 & 57 & 33,4 & 139 & 70 & 69 \\
\hline ZON-6 & 69 & 107 & 100 & 60,9 & 58,5 & 176 & 57 & 25,5 & 119 & 68 & 51 \\
\hline ZON-7 & 75 & 108 & 94 & 59,0 & 54,7 & 183 & 57 & 25,3 & 126 & 69 & 57 \\
\hline
\end{tabular}




\section{Bijlage 5 Voerverbruik jongvee}

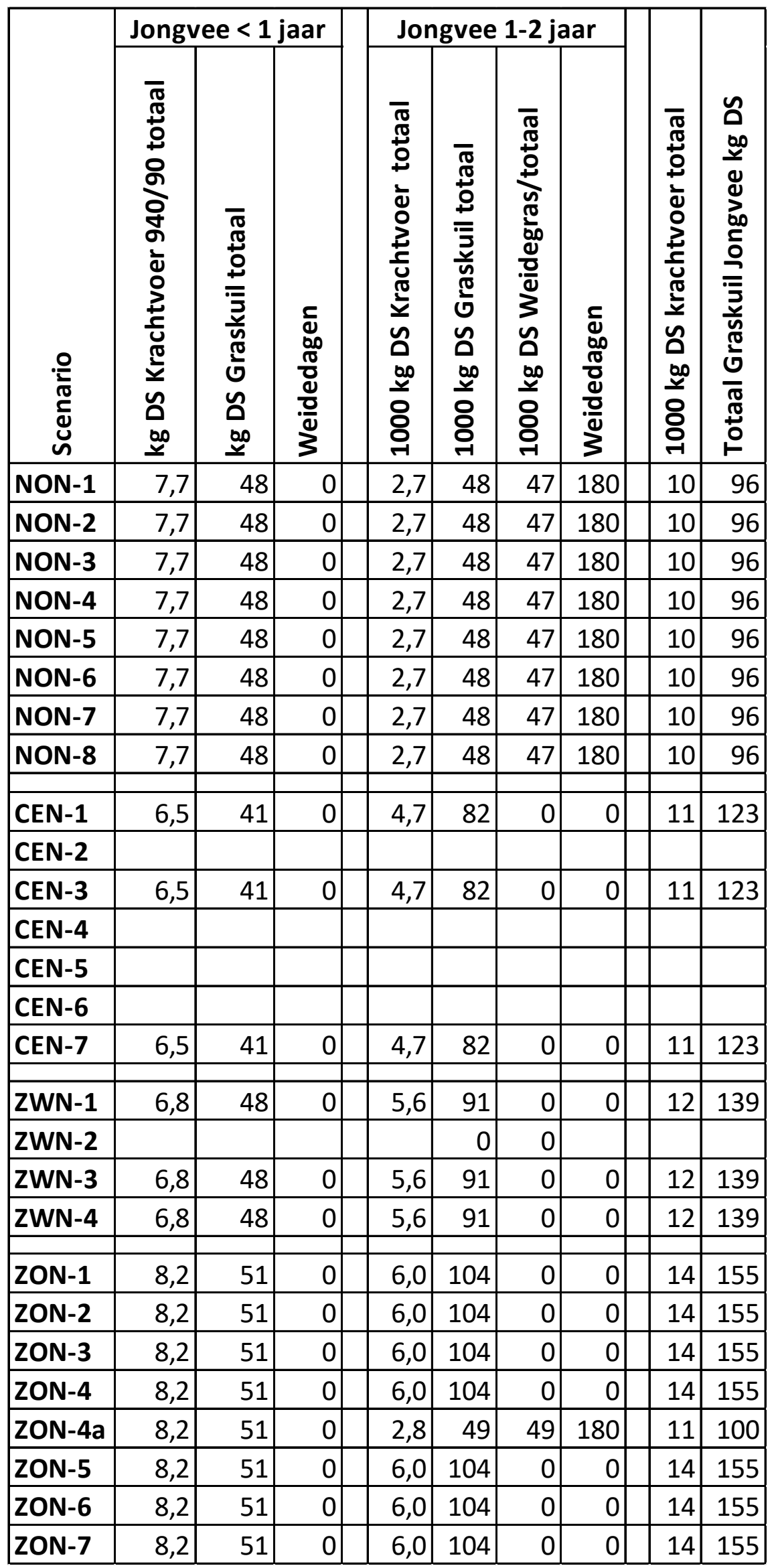




\section{Bijlage 6 Rantsoen melkkoeien}

\begin{tabular}{|c|c|c|c|c|c|c|c|c|c|c|c|c|c|c|}
\hline 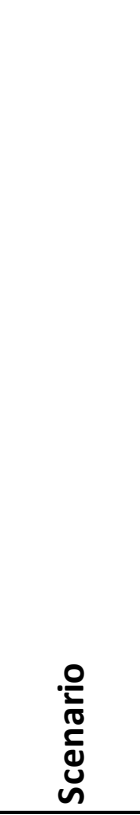 &  & 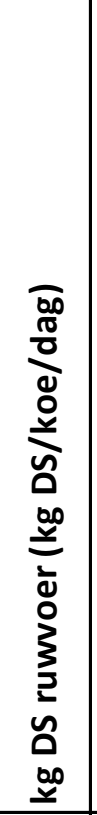 & 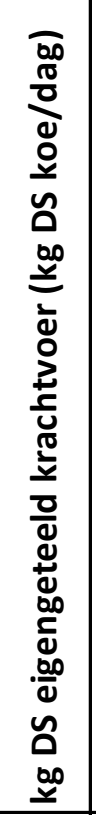 & 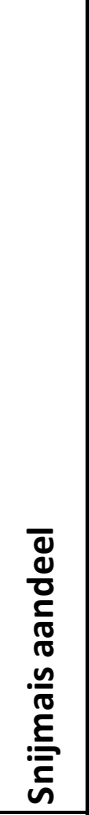 &  & 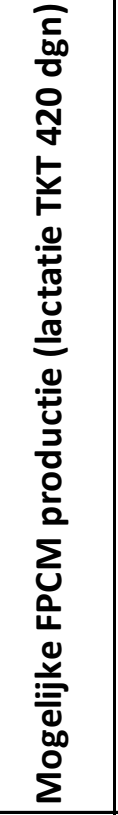 & 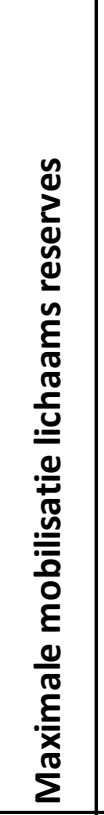 & 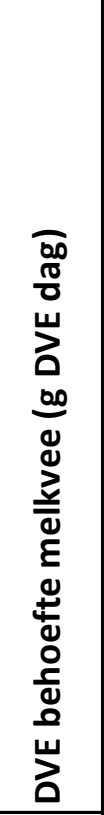 & 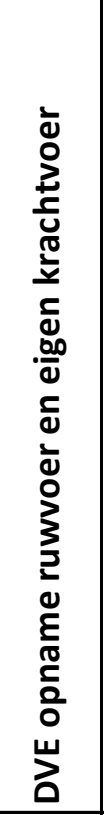 & 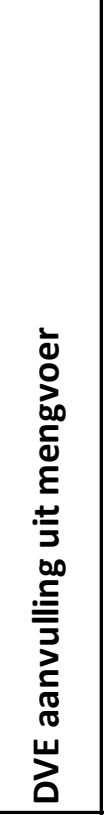 & 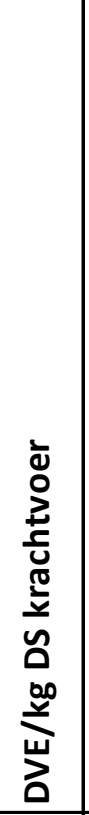 & 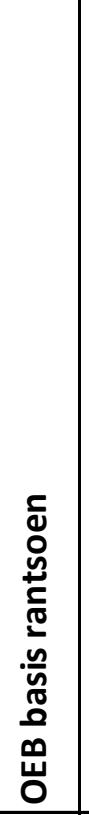 & $\begin{array}{l}\text { \& } \\
\text { 山 } \\
\text { ப̇ }\end{array}$ & $\begin{array}{l}\text { 옥 } \\
\text { N } \\
\text { Шे }\end{array}$ \\
\hline NON-1 & 21,1 & 14,1 & 0,00 & 40,0 & 9130 & 10506 & -498 & 1691 & 817 & 874 & 125 & 234 & 0,81 & 0,19 \\
\hline NON-2 & 21,1 & 14,1 & 0,00 & 40,0 & 9130 & 10506 & -498 & 1691 & 817 & 874 & 125 & 234 & 0,81 & 0,19 \\
\hline NON-3 & 21,1 & 14,1 & 0,00 & 40,0 & 9130 & 10506 & -498 & 1691 & 817 & 874 & 125 & 234 & 0,81 & 0,19 \\
\hline NON-4 & 21,1 & 14,1 & 0,00 & 40,0 & 9130 & 10506 & -498 & 1691 & 817 & 874 & 125 & 234 & 0,81 & 0,19 \\
\hline NON-5 & 21,3 & 16,0 & 0,00 & 33,7 & 9124 & 10499 & -481 & 1690 & 1041 & 648 & 121 & -65 & 0,84 & 0,16 \\
\hline NON-6 & 21,6 & 14,6 & 0,88 & 23,0 & 9099 & 10470 & -499 & 1685 & 920 & 765 & 109 & 492 & 0,83 & 0,17 \\
\hline NON-7 & 21,6 & 14,6 & 0,88 & 23,0 & 9099 & 10470 & -499 & 1685 & 920 & 765 & 109 & 492 & 0,83 & 0,17 \\
\hline NON-8 & 21,1 & 14,1 & 0,00 & 40,0 & 9130 & 10506 & -498 & 1691 & 817 & 874 & 125 & 234 & 0,81 & 0,19 \\
\hline CEN-1 & 21,9 & 13,4 & 0,00 & 38,3 & 9449 & 10872 & -353 & 1750 & 765 & 985 & 116 & 237 & 0,88 & 0,12 \\
\hline CEN-2 & & & & & & & & & & & & & & \\
\hline CEN-3 & 21,9 & 13,4 & 0,00 & 38,3 & 9449 & 10872 & -353 & 1750 & 765 & 985 & 116 & 237 & 0,88 & 0,12 \\
\hline CEN-4 & & & & & & & & & & & & & & \\
\hline CEN-5 & & & & & & & & & & & & & & \\
\hline CEN-6 & & & & & & & & & & & & & & \\
\hline CEN-7 & 22,1 & 13,6 & 0,00 & 37,8 & 9294 & 10695 & -395 & 1721 & 690 & 1032 & 122 & 293 & 0,84 & 0,16 \\
\hline ZWN-1 & 22,6 & 14,6 & 0,00 & 34,4 & 9363 & 10773 & -368 & 1734 & 870 & 864 & 108 & 303 & 0,94 & 0,06 \\
\hline ZWN-2 & 0,0 & 0,0 & 0,00 & 0,0 & 0 & 0 & 0 & 0 & 0 & 0 & 0 & 0 & 0,00 & 0,00 \\
\hline ZWN-3 & 21,5 & 13,5 & 1,58 & 17,6 & 9415 & 10832 & -355 & 1744 & 852 & 892 & 111 & 334 & 0,91 & 0,09 \\
\hline ZWN-4 & 21,2 & 13,3 & 0,00 & 17,9 & 9274 & 10671 & -391 & 1718 & 831 & 886 & 111 & 438 & 0,91 & 0,09 \\
\hline ZON-1 & 21,1 & 13,8 & 0,00 & 35,8 & 9177 & 10559 & -421 & 1700 & 793 & 907 & 126 & 270 & 0,81 & 0,19 \\
\hline ZON-2 & 21,1 & 13,8 & 0,00 & 35,8 & 9177 & 10559 & -421 & 1700 & 793 & 907 & 126 & 270 & 0,81 & 0,19 \\
\hline ZON-3 & 21,1 & 13,8 & 0,00 & 35,8 & 9177 & 10559 & -421 & 1700 & 793 & 907 & 126 & 270 & 0,81 & 0,19 \\
\hline ZON-4 & 21,1 & 13,8 & 0,00 & 35,8 & 9177 & 10559 & -421 & 1700 & 793 & 907 & 126 & 270 & 0,81 & 0,19 \\
\hline ZON-4a & 21,1 & 14,7 & 0,00 & 55,0 & 9183 & 10567 & -379 & 1701 & 814 & 887 & 138 & 80 & 0,71 & 0,29 \\
\hline ZON-5 & 21,9 & 13,5 & 0,00 & 28,4 & 9158 & 10538 & -428 & 1696 & 670 & 1027 & 123 & 404 & 0,83 & 0,17 \\
\hline ZON-6 & 20,9 & 14,5 & 0,00 & 25,1 & 9189 & 10573 & -395 & 1702 & 930 & 772 & 120 & 111 & 0,85 & 0,15 \\
\hline ZON-7 & 21,0 & 14,6 & 0,63 & 34,9 & 9165 & 10545 & \begin{tabular}{|c|}
-394 \\
\end{tabular} & 1697 & 862 & 835 & 131 & 234 & 0,76 & 0,24 \\
\hline
\end{tabular}




\section{Bijlage 7 Ruwvoerverbruik melkkoeien}

\begin{tabular}{|c|c|c|c|c|c|c|c|c|c|c|c|c|c|c|}
\hline & \multicolumn{10}{|c|}{ Ruwvoerverbruik } & \multicolumn{4}{|c|}{ Ruwvoeroverschot } \\
\hline & 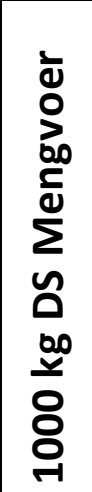 & 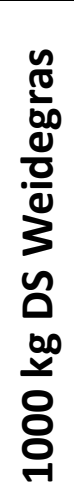 & 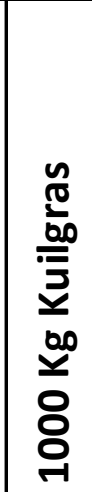 & 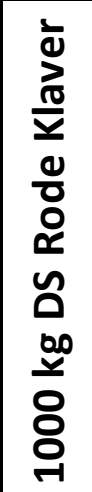 & 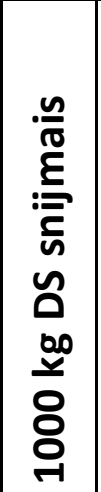 &  & 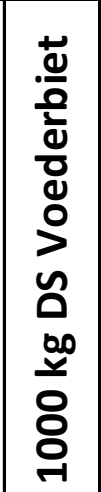 & 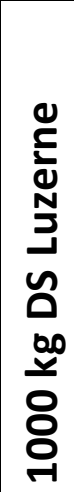 & 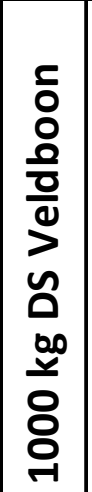 & 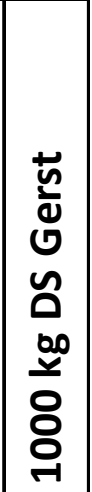 & 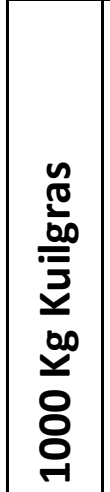 & 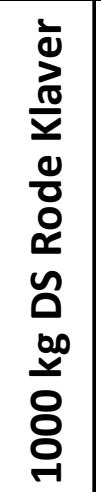 & 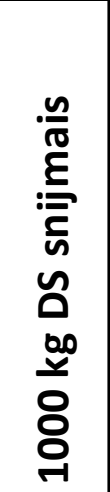 & 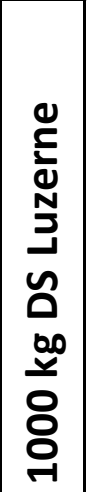 \\
\hline NON-1 & 282 & 24 & 320 & & 229 & & & & & & 75 & & & \\
\hline NON-2 & 282 & 24 & 320 & & 229 & & & & & & 75 & & & \\
\hline NON-3 & 282 & 24 & 320 & & 229 & & & & & & 75 & & & \\
\hline NON-4 & 282 & 24 & 320 & & 229 & & & & & & 75 & & & \\
\hline NON-5 & 217 & 24 & 292 & & 218 & & 112 & & & & 40 & & & \\
\hline NON-6 & 285 & 24 & 395 & & 135 & & & & 36 & & & & -21 & \\
\hline NON-7 & 285 & 24 & 395 & & 135 & & & & 36 & & & & -21 & \\
\hline NON-8 & 282 & 24 & 320 & & 229 & & & & & & 75 & & & \\
\hline CEN-1 & 319 & & 312 & & 194 & & & & & & $\mid 161$ & & & \\
\hline \multicolumn{15}{|l|}{ CEN-2 } \\
\hline CEN-3 & 319 & & 312 & & 194 & & & & & & 161 & & & \\
\hline \multicolumn{15}{|l|}{ CEN-4 } \\
\hline \multicolumn{15}{|l|}{ CEN-5 } \\
\hline \multicolumn{15}{|l|}{ CEN-6 } \\
\hline CEN-7 & 319 & & 118 & 200 & 193 & & & & & & & 194 & & \\
\hline ZWN-1 & 295 & 42 & 310 & & 185 & & & & & & 71 & & & \\
\hline \multicolumn{15}{|l|}{ ZWN-2 } \\
\hline ZWN-3 & 295 & 42 & 311 & & 88 & 58 & & & & & 69 & & & \\
\hline ZWN-4 & 293 & 42 & 359 & & 88 & & & & & & 21 & & & 77 \\
\hline ZON-1 & 285 & & 350 & & 196 & & & & & & & & -45 & \\
\hline ZON-2 & 285 & & 350 & & 196 & & & & & & & & -45 & \\
\hline ZON-3 & 285 & & 350 & & 196 & & & & & & & & -45 & \\
\hline ZON-4 & 285 & & 350 & & 196 & & & & & & & & -45 & \\
\hline ZON-4a & 253 & 25 & 235 & & 318 & & & & & & & & -167 & \\
\hline ZON-5 & 330 & & 88 & & 151 & & & & & & & 15 & & \\
\hline ZON-6 & 253 & & 350 & & 144 & & 78 & & & & & & -65 & \\
\hline ZON-7 & 250 & & 350 & & 201 & & & & & 25 & & & -129 & \\
\hline
\end{tabular}




\section{Bijlage 8 Melkproductie}
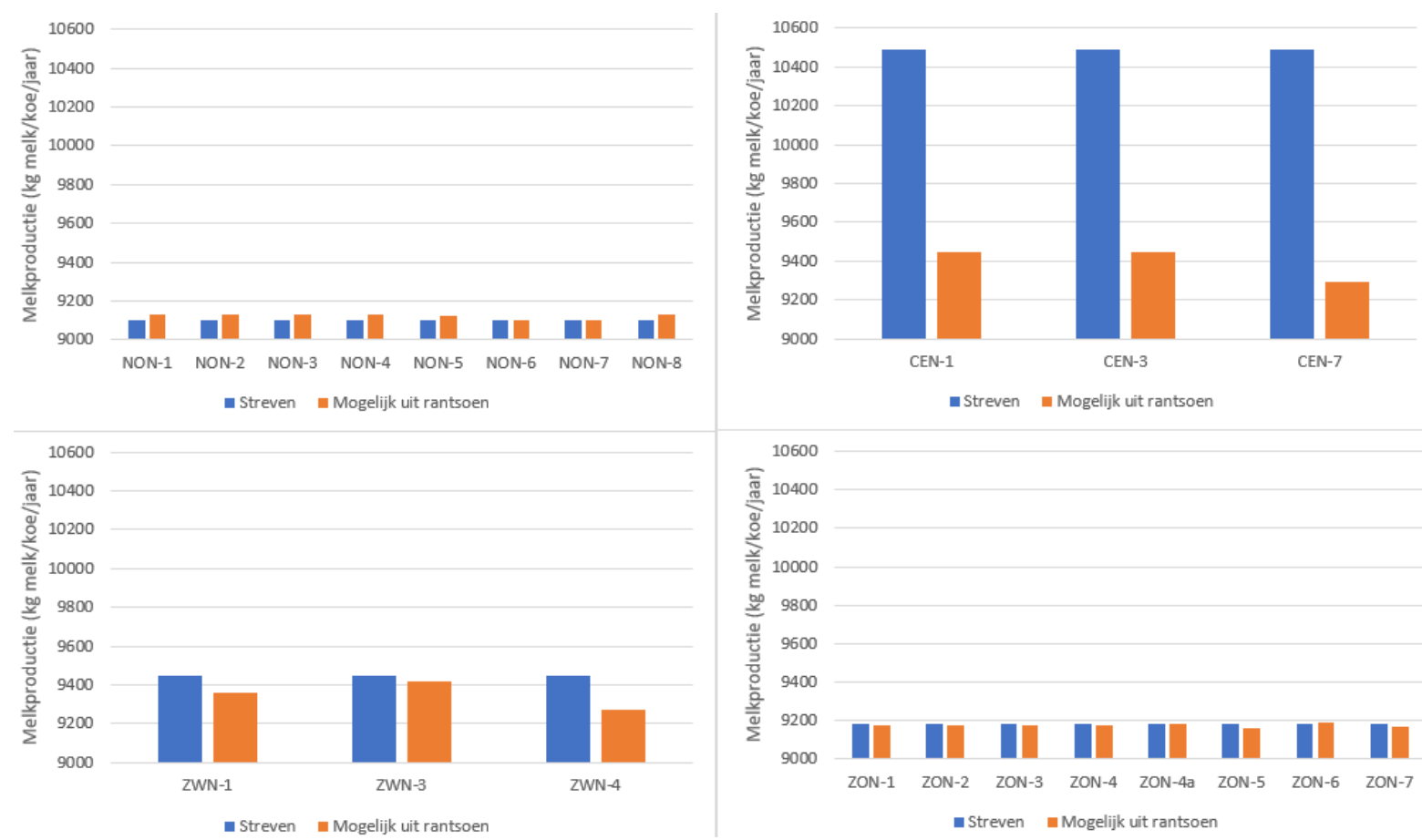
Correspondentie adres voor dit rapport: Postbus 16

6700 AA Wageningen

T 0317480700

www.wur.nl/plant-research

Rapport WPR-1062
De missie van Wageningen University \& Research is 'To explore the potential of nature to improve the quality of life'. Binnen Wageningen University \& Research bundelen Wageningen University en gespecialiseerde onderzoeksinstituten van Stichting Wageningen Research hun krachten om bij te dragen aan de oplossing van belangrijke vragen in het domein van gezonde voeding en leefomgeving. Met ongeveer 30 vestigingen, 5.000 medewerkers en 10.000 studenten behoort Wageningen University \& Research wereldwijd tot de aansprekende kennisinstellingen binnen haar domein. De integrale benadering van de vraagstukken en de samenwerking tussen verschillende disciplines vormen het hart van de unieke Wageningen aanpak.

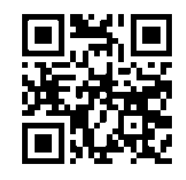

